\title{
Big Sky Carbon Sequestration Partnership
}

\author{
Quarterly Report for period July 1, 2004 - Sept 30, 2004 \\ By Susan M. Capalbo \\ Report issued October 31, 2004 \\ DOE Award Number DE-FC26-03NT41995 \\ Montana State University \\ 207 Montana Hall; Bozeman, MT 59717-2460
}

\section{Partners}

Boise State University

CGISS, MG 206, Boise, ID 83725-1536

EnTech Strategies, LLC

1862 Mintwood Place NW \#101, Washington, DC 20009

National Carbon Offset Coalition

305 W Mercury St, \#408, Butte, MT 59701

South Dakota School of Mines \& Technology

501 East Saint Joseph Street, Rapid City, SD 57701-3995

Texas A \& M University

2126 TAMU, College Station, TX 77843-2126

University of Idaho

1776 Science Center Drive, Idaho Falls, ID 83402

\author{
Idaho National Engineering and Environmental Laboratory (INEEL) \\ PO Box 1625, Idaho Falls, ID 83415 \\ Los Alamos National Laboratory (LANL) \\ PO Box 1663, Los Alamos, NM 87545 \\ Montana Governor's Carbon Sequestration Working Group \\ Capitol Building, PO Box 200801, Helena, MT 59620-0801 \\ The Confederated Salish and Kootenai Tribes \\ PO Box 278, Pablo, MT 59855 \\ Nez Perce Tribe \\ PO Box 365, Lapwai, ID 83540 \\ Inland Northwest Research Alliance \\ 151 N. Ridge Ave., Idaho Falls, ID 83402
}

Idaho Carbon Sequestration Advisory Committee / Idaho Soil Conservation Commission PO Box 790, Boise, ID 83701

Montana Bureau of Mines and Technology

Montana Tech, 1300 West Park St., Butte, MT 59701-8997

Western Governors' Association

1515 Cleveland Place, Ste 200, Denver, CO 80202-5114

Wyoming Carbon Sequestration Advisory Committee

2219 Carey Avenue, Cheyenne, WY 82002

Montana Department of Environmental Quality

PO Box 200901, 1520 East Sixth Avenue, Helena, MT 59620-0901 


\section{DISCLAIMER}

This report was prepared as an account of work sponsored by an agency of the United States Government. Neither the United States Government nor any agency thereof, nor any of their employees, makes any warranty, express or implied, or assumes any legal liability or responsibility for the accuracy, completeness, or usefulness of any information, apparatus, product, or process disclosed, or represents that its use would not infringe privately owned rights. Reference herein to any specific commercial product, process, or service by trade name, trademark, manufacturer, or otherwise does not necessarily constitute or imply its endorsement, recommendation, or favoring by the United States Government or any agency thereof. The views and opinions of authors expressed herein do not necessarily state or reflect those of the United States Government or any agency thereof. 


\section{ABSTRACT}

The Big Sky Carbon Sequestration Partnership, led by Montana State University, is comprised of research institutions, public entities and private sectors organizations, and the Confederated Salish and Kootenai Tribes and the Nez Perce Tribe. Efforts under this Partnership fall into four areas: evaluation of sources and carbon sequestration sinks; development of GIS-based reporting framework; designing an integrated suite of monitoring, measuring, and verification technologies; and initiating a comprehensive education and outreach program. At the first two Partnership meetings the groundwork was put in place to provide an assessment of capture and storage capabilities for $\mathrm{CO}_{2}$ utilizing the resources found in the Partnership region (both geological and terrestrial sinks), that would complement the ongoing DOE research. During the third quarter, planning efforts are underway for the next Partnership meeting which will showcase the architecture of the GIS framework and initial results for sources and sinks, discuss the methods and analysis underway for assessing geological and terrestrial sequestration potentials. The meeting will conclude with an ASME workshop (see attached agenda).

The region has a diverse array of geological formations that could provide storage options for carbon in one or more of its three states. Likewise, initial estimates of terrestrial sinks indicate a vast potential for increasing and maintaining soil $\mathrm{C}$ on forested, agricultural, and reclaimed lands. Both options include the potential for offsetting economic benefits to industry and society. Steps have been taken to assure that the GIS-based framework is consistent among types of sinks within the Big Sky Partnership area and with the efforts of other western DOE partnerships. Efforts are also being made to find funding to include Wyoming in the coverage areas for both geological and terrestrial sinks and sources.

The Partnership recognizes the critical importance of measurement, monitoring, and verification technologies to support not only carbon trading but all policies and programs that DOE and other agencies may want to pursue in support of GHG mitigation. The efforts begun in developing and implementing MMV technologies for geological sequestration reflect this concern. Research is also underway to identify and validate best management practices for soil $\mathrm{C}$ in the Partnership region, and to design a risk/cost effectiveness framework to make comparative assessments of each viable sink, taking into account economic costs, offsetting benefits, scale of sequestration opportunities, spatial and time dimensions, environmental risks, and long-term viability. Scientifically sound information on MMV is critical for public acceptance of these technologies.

Two key deliverables were completed in the second quarter-a literature review/database to assess the soil carbon on rangelands, and the draft protocols, contracting options for soil carbon trading. The protocols developed for soil carbon trading are unique and provide a key component of the mechanisms that might be used to efficiently sequester GHG and reduce $\mathrm{CO}_{2}$ concentrations. While no key deliverables were due during the third quarter, progress on other deliverables is noted in the PowerPoint presentations and in this report. A series of meetings held during the second and third quarters have laid the foundations for assessing the issues surrounding carbon sequestration in this region, the need for a holistic approach to meeting energy demands and economic development potential, and the implementation of government programs or a market-based setting for soil $\mathrm{C}$ credits. These meetings provide a connection to stakeholders in the region and a basis on which to draw for the DOE PEIS hearings. 
In the fourth quarter, three deliverables have been completed, some in draft form to be revised and updated to include Wyoming. This is due primarily to some delays in funding to LANL and INEEL and the approval of a supplemental proposal to include Wyoming in much of the GIS data sets, analysis, and related materials. (See Appendix for the Supplemental request and modified timelines.) The deliverables are discussed in the following sections and greater details are provided in the materials that are attached to this report. In August 2004, a presentation was made to Pioneer Hi-Bred, discussing the Partnership and the synergies with terrestrial sequestration, agricultural industries, and ongoing, complimentary USDA efforts. The Partnership organized a Carbon session at the INRA 2004 Environmental and Subsurface Science Symposium in September 2004; also in September, a presentation was made to the Wyoming Carbon Sequestration Advisory Committee, followed up with a roundtable discussion. Members of the committee are interested in being part of the Partnership, contributing their expertise on carbon sequestration potential on Wyoming cropland, rangeland, and forestlands, as well as contributing to the public outreach and education throughout WY. Substantial progress is being made on the decision support tools for assessing the participation of producers and landowners in terrestrial sequestration. South Dakota School of Mines and Technology have developed a working version of C-Lock to be used in pilot trades, and National Carbon Offset Coalition is working with Chicago climate exchange on background analysis and mechanisms for pilot trades. A third Partnership meeting was held in August, 2004 followed by an AMSE symposium on carbon sequestration (see Appendix for agendas).

The Partnership has nearly completed state-level greenhouse gas (GHG) emission inventories for South Dakota, Montana and Idaho. Per-capita emissions are lower than the national average in Montana, but higher in South Dakota and Idaho. Montana hosts the largest number of industrial point sources, while South Dakota has the highest livestock-related emissions of GHGs. Major point sources are being located within the project GIS in order to help assess source-sink spatial relationships. The data and methodology to conduct an assessment of agricultural GHG sources and sink potential are being finalized. In addition, the C-Lock team has begun to develop a pilot soil carbon sale on the Cheyenne River Sioux Reservation, to serve as a proof-of-concept for the C-Lock system.

Possible rangeland terrestrial sinks throughout the Big Sky project area have been identified and a literature review to support decisions for increasing carbon sequestration for areas identified as having potential as carbon sinks has been completed. Climatic potential, MLRA, and land tenure were selected to spatially stratify rangeland cover types into easily identifiable areas where sequestration programs could potentially be initiated. Climatic potential for carbon sequestration was classified into four categories based on annual precipitation: no potential - less than $130 \mathrm{~mm}$; low potential - 130 to $230 \mathrm{~mm}$; moderate potential - 230 to $460 \mathrm{~mm}$; and high potential - greater than $460 \mathrm{~mm}$. Since programs will not likely be implemented on Federal lands, only Indian reservations and private or other non-federal lands are discussed. For each of the Big Sky states (Idaho, South Dakota, and Montana) non-federal land areas and Indian reservations classified as rangeland have been identified according to their potential for carbon sequestration. This information can be used to target areas that will likely have the greatest return on investments in rangeland carbon sequestration projects. 
The education and outreach efforts have resulted in a comprehensive plan which serves as a guide for implementing the outreach activities under Phase I. The public website is established (www.bigskyco2.org), along with a Partnership logo. We have made presentations to stakeholders and policy makers including participation in the June PEIS meeting in Bozeman, connections to other federal and state agencies concerned with GHG emissions, climate change, and efficient and environmentally-friendly energy production. In addition, the Partnership has plans for integration of our outreach efforts with the students, especially at the tribal colleges and at the universities involved in our Partnership. This includes collaboration with the film and media arts departments at MSU and with the U.S.-Norway Summer School, extended outreach efforts at LANL and INEEL, and with the student section of the ASME. Finally, the Big Sky Partnership was involved in two key forums: the NETL Carbon Sequestration Conference (May 04) and a special session sponsored by the Western Governors' Association at the annual Western Governors' meeting on carbon sequestration. The session was chaired by Governor Rounds from South Dakota. Presentations are posted on our website. The Partnership also was involved in the planning and kickoff meeting for the U.S.-Norway bilaterals held in May in New Orleans in an effort to facilitate an exchange of research and students/faculty. This resulted in the US-Norway Summer School on carbon sequestration organized by Pam Tomski which was held in August 2004. At the Big Sky Partnership sponsored meeting in August 2004 and at the ASME Carbon Sequestration Symposium, the public was invited as well as the state agencies and other interested parties. 


\section{TABLE OF CONTENTS}

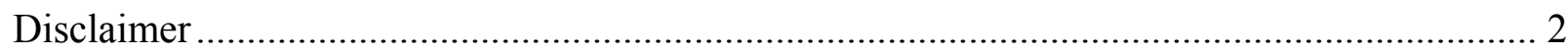

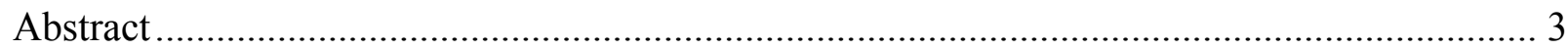

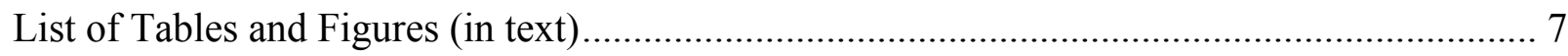

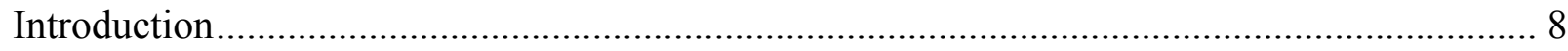

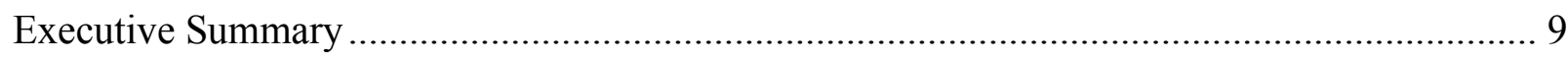

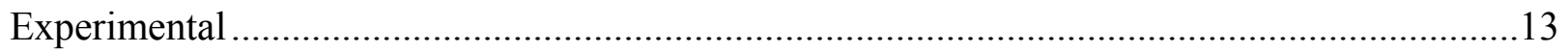

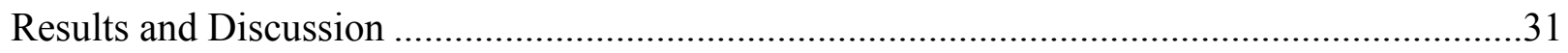

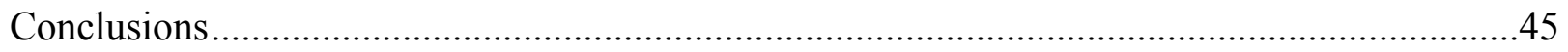

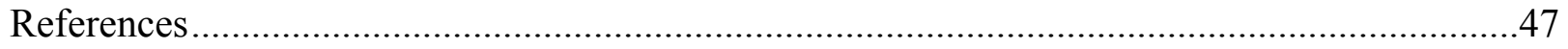

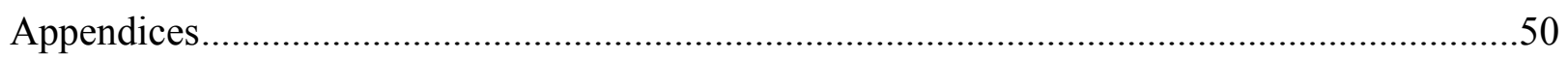

Fact Sheet for Big Sky Carbon Sequestration Partnership, June 2004

Big Sky Carbon Sequestration Partnership Advisory Committee

Supplementary Figures and Tables

Agenda for Big Sky Regional Carbon Sequestration Partnership meeting, August 24-26, 2004, INEEL, Idaho Falls, ID

Agenda for ASME Carbon Sequestration Symposium, August 26, 2004, Idaho Falls, ID

Request for Supplemental DOE Support

Big Sky Regional Carbon Sequestration Partnership website

Deliverable 4 - Geologic Carbon Sequestration GIS Database Structure and Summary of Infrastructure Data Compilation and Analysis Inputs

Deliverable 9 - Terrestrial GIS Data

Agenda for INRA Symposium, September 21, 2004, Spokane, WA, and Abstracts of presentations given at INRA Symposium

National Carbon Offset Coalition brochures for January 2005 workshops (drafts)

News article on Carbon Cropping, Post Register, Idaho Falls, ID, August 30, 2004

Patent Clearance document 


\section{LIST OF TABLES AND FIGURES (in text)}

\section{Figures (in text)}

Figure 1. Well locations by formation ........................................................................... 18

Figure 2. Locations of six farms in north central Montana for the on-farm cropping system

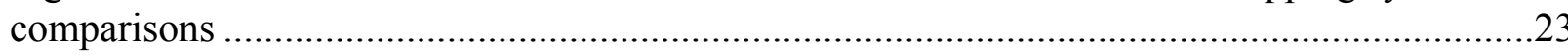

Figure 3. Hypothetical sampling scheme for long-term soil carbon studies...........................23

Figure 4. Nitrous oxide gas samples are collected using a vented chamber made of plexiglass.

Without cover (left). With cover (right)

Figure 5. Seasonal distribution of $\mathrm{N}_{2} \mathrm{O}$ emissions from Conrad and Great Falls farm sites in north central Montana.

Figure 6. Predicted organic carbon (OC) and inorganic carbon (IC) using VNIR diffuse reflectance spectroscopy

\section{Tables (in text)}

Table 1. Soil organic carbon $\left(\mathrm{t} \mathrm{ha}^{-1}\right)$ by depth for each plot at Chester, Collins, Conrad, Great Falls, Kremlin, and Power, Sept - Oct. 2002.

Table 2. Crop biomass ( $\mathrm{t} \mathrm{ha}^{-1}$ ) for each plot at Chester, Collins, Conrad, Great Falls, Kremlin and Power, 2003

Table 3. Crop biomass ( $\mathrm{t} \mathrm{ha}^{-1}$ ) for each plot at Chester, Collins, Conrad, Great Falls, Kremlin and Power, 2004 .38

Table 4. ANOVA results for total wheat biomass, 2004 .38 


\section{INTRODUCTION}

The Big Sky Regional Carbon Sequestration Partnership was initially called the Northern Rockies and Great Plains Regional Carbon Sequestration Partnership. The proposed name change was initiated in December 2003, and has received DOE/NETL approval. The Big Sky Partnership, led by Montana State University, Bozeman, MT, seeks to: identify and catalogue $\mathrm{CO}_{2}$ sources and promising geologic and terrestrial storage sites, develop a risk assessment and decision support framework to optimize the areas' carbon-storage portfolio, enhance marketbased carbon-storage methods, identify and measure advanced greenhouse gas-measurement technologies to improve verification, support voluntary trading and stimulate economic development, call upon community leaders to define carbon-sequestration strategies, and create forums that involve the public. Idaho, Montana and South Dakota are currently served by this Partnership that is comprised of 13 organizations and the Confederated Salish and Kootenai Tribes and the Nez Perce Tribe. Additional collaboration is being sought with neighboring states and Canada, and with other private and non-profit entities. To date, we are in the process of discussions for Phase II input from Puget Sound Energy and University of Wyoming/State of Wyoming, Montana Dept of Environmental Quality, Ducks Unlimited, and Rural electric coops. Montana Tech-Montana Bureau of Mines and Geology and the Idaho Carbon Sequestration Advisory Committee/Idaho Soil Conservation Commission are new members of the Partnership. Inland Northwest Research Alliance (INRA) and Western Governors' Association (WGA) have provided support for our Partnership since the onset and are members of the Partnership.

\author{
Original Partners include \\ Montana State University \\ Boise State University \\ South Dakota School of Mines \\ and Technology \\ Texas A\&M \\ University of Idaho \\ The Sampson Group \\ EnTech Strategies \\ Environmental Financial Products
}

\section{New Partners include}

Idaho Carbon Sequestration Advisory Committee/Idaho Soil Conservation Commission

Inland Northwest Research Alliance

Montana Tech-Montana Bureau of Mines and Geology

Western Governors' Association

Wyoming Carbon Sequestration Advisory Committee

Montana Department of Environmental Quality

\author{
Nez Perce Tribe \\ The Confederated Salish \\ and Kootenai Tribes \\ Idaho National Engineering and \\ Environmental Laboratory \\ Los Alamos National Laboratory \\ Montana Governor's Carbon \\ Sequestration Working Group \\ National Carbon Offset Coalition
}

\section{New Partners (in progress) include \\ Puget Sound Energy}




\section{EXECUTIVE SUMMARY}

For reporting purposes, the activities and results for the Big Sky Partnership are organized into four somewhat overlapping components or efforts, with the related tasks from the workplan noted by each:

- Evaluation of sources and potential for carbon sequestration sinks: Tasks 1,2,4,5,6,7

- Development of GIS-based framework and carbon cyberinfrastructure: Task 3

- Advanced concepts for monitoring, measuring, and verification; implementation, carbon trading, and evaluation: Tasks 9-20

- Education and outreach efforts. Tasks 8, 21-25

The Partnership held their first meeting in Bozeman in October, 2003; the agenda included a discussion of the roles and contributions of each partner, the process of creating continuity among the geological and terrestrial efforts to provide a comprehensive assessment of capture and storage capabilities, and the unique contributions and research that our Partnership could provide to the DOE efforts. The subsequent efforts during the first three months of the grant focused on startup activities in each of the four areas.

A second Partnership meeting was held on March 1-3, 2004 at Los Alamos National Lab. The agenda for the meeting included Partnership reports, evaluation of progress and assessment of coverage, Phase II strategic planning, LANL overview and collaborations, and seminar presentations. A copy of the agenda was included with the second quarter report.

The Big Sky Partnership has had Partnership recognition at two key meetings during the third quarter: the DOE/NETL Annual Carbon Sequestration conference in May, 2004, and the Western Governors' Annual Meeting in June 2004. Other presentations are listed with the materials for this third quarterly report.

In the fourth quarter, efforts via Tasks and deliverables relate primarily to data sets for sources, terrestrial and geological sinks and analysis. The draft deliverables are attached to this report. In September, 2004 a presentation was made to the Wyoming Carbon Sequestration Advisory Committee, followed up with a roundtable discussion. Substantial progress is being made on the decision support tools for assessing the participation of producers and landowners in terrestrial sequestration. South Dakota School of Mines and Technology have developed a working version of C-Lock to be used in pilot trades, and National Carbon Offset Coalition is working with Chicago climate exchange on background analysis and mechanisms for pilot trades. A third Partnership meeting was held in August, 2004 followed by an AMSE symposium on carbon sequestration. Agendas for both are attached. The Partnership also organized and sponsored a session at the INRA "Environmental and Subsurface Science Symposium 2004” in Spokane, ID, and made a presentation to Pioneer Hi-Bred Intl. in August 2004, Des Moines/Johnston, IA

Evaluation of sources and sinks (Tasks 1, 2, 4, 5, 6, 7). Activities during the fourth performance period were focused on the methodologies for characterizing the potential for 
geological and terrestrial sequestration sinks, compilation of data, and identifying and cataloging industrial and agricultural GHG sources. The Partnership Geologic Sequestration and Geographical Information System (GIS) support has focused on the creation of a database structure for collection of geologic sequestration data and summarizing the types of infrastructure information that are being collected in Idaho, Montana, and contiguous geologic regions of Wyoming. The Partnership has developed a uniform strategy for assessing the mineralization trapping potential across rocks types. These capabilities are being used to determine the geologic sequestration potential in the Big Sky region. We have established a geological sink assessment approach and screening criteria, and nearing completion on compiling county-level data on tillage and land use for the terrestrial component. Both the geological and terrestrial component is resulting in data layers that will allow us to assess the suitability for carbon sequestration in the Big Sky Partnership region as well as the potential for locating future energy facilities in our region.

For geological sinks, the potential for subsurface formation of carbon dioxide sequestration focused on solubility and mineralization trapping, and examined the technical feasibility, the time frame until implementation, and offsetting economic benefits. For the terrestrial sinks, the methodologies have been focusing on both technical and economic feasibility. Increasing soil $\mathrm{C}$ levels are dependent upon both the technical capacity of the soils to sequester and utilize additional carbon, and the incentives provided for landowners to change land use management practices. Activities to identify sources and assessment of transportation infrastructure are currently focused on identifying the state and federal databases and agencies, and addressing uncertainties inherent in matching/combining data sources. (See Appendix to this fourth quarter report)

Task 1. The Partnership's and South Dakota School of Mines and Technology's responsibilities included the preparation of major GHG source inventories for SD, MT and ID. With the exception of terrestrial (land-use related) sources, this inventory is largely complete. We used EPA-EIIP inventory methodologies, with local supplementation where possible, to develop aggregate estimates of greenhouse gas (GHG) emissions over the 2000-2002 period for each state. Point-sources of $\mathrm{CO}_{2}, \mathrm{~N}_{2} \mathrm{O}, \mathrm{CH}_{4}$ and trace $\mathrm{GHG}$ included energy utilities, petroleum processing and other industrial facilities. We also developed sectoral estimates of energy-related emissions based on data from the DOE-EIA. Methane and $\mathrm{N}_{2} \mathrm{O}$ emissions from agricultural activities, primarily livestock, were based on Census of Agriculture data on livestock populations. Estimates of emissions from forest land-use change were drawn from a US Forest Service report on forest carbon stocks. Estimates of net emissions due to agricultural land management changes, which will be derived from the CENTURY model, are under development. The same process will allow us to estimate terrestrial sink potential in this region.

Idaho, Montana and South Dakota emitted approximately 11.7, 3.0 and 10.1 MMTCE, respectively, in 2002, or 9, 3 and 13 MTCE per capita. Although Idaho and Montana had larger industrial emissions, these were offset by increases in forest $\mathrm{C}$ uptake. Because a large proportion of Idaho's energy is produced by hydroelectric power, its largest category of emissions is imported electricity; the same is true in South Dakota. In Montana, petroleum refining and other heavy industry constitutes the largest GHG source category. Livestock-related GHG emissions also comprise $15 \%$ of South Dakota's GHG emissions. 
The Texas A\&M University research team is contributing to the Big Sky Partnership by identifying possible rangeland terrestrial sinks throughout the Big Sky project area and providing a literature review to support decisions for increasing carbon sequestration for areas identified as having potential as carbon sinks. A library search was completed of over 800 references linked to over 150 selected articles relating to terrestrial carbon sequestration, land use change, vegetation change, restoration, remote sensing and modeling. Included in this search is a summary of Natural Resources Conservation Service (NRCS) data for each of the Major Land Resource Areas (MLRAs) in the Big Sky Partnership area.

Climatic potential, MLRA, and land tenure were selected to spatially stratify rangeland cover types into easily identifiable areas where sequestration programs could potentially be initiated. Climatic potential for carbon sequestration was classified into four categories based on annual precipitation: no potential - less than $130 \mathrm{~mm}$; low potential - 130 to $230 \mathrm{~mm}$; moderate potential - 230 to $460 \mathrm{~mm}$; and high potential - greater than $460 \mathrm{~mm}$. Since programs will not likely be implemented on Federal lands, only Indian reservations and private or other non-federal lands are discussed. For each of the Big Sky states (Idaho, South Dakota, and Montana) nonfederal land areas and Indian reservations classified as rangeland have been identified according to their potential for carbon sequestration. This information can be used to target areas that will likely have the greatest return on investments in rangeland carbon sequestration projects.

The material presented in this report addresses problems in verifying changes in carbon stocks associated with the high cost and time involved with repeated sampling and analysis. The objective is to demonstrate the practicality of near infrared reflectance spectroscopy (NIR) as a technique for reducing the cost and time required for sample analysis. We demonstrate a technique that identifies spectrally unique samples for laboratory analysis and equation development, and compare the accuracy and cost between NIR techniques and standard laboratory procedures. Results of a general soil carbon equation built on a diverse assortment of soils collected throughout the country are presented as well as the prediction results for several carbon fractions.

GIS-based efforts (Task 3). The GIS activities have involved LANL and INEEL as well as the research universities, and are focusing on building a database to meet the immediate Big Sky modeling and analysis needs, and on planning for multi-partnership, NATCARB, DOE, and national coordination, in the context of the emerging national cyberinfrastructure. We also have a major effort to examine the potential for using GIS-based systems in both research and outreach/education efforts of the Partnership, and the development of complimentary efforts with the West and Southwest carbon sequestration partnerships. LANL GISLab team leader Paul Rich continues in the role of coordination of Big Sky GIS efforts, Randy Lee (INEEL) continues as lead for geologic data, and Maribeth Price (SDSMT) continues as lead for terrestrial data.

Advanced Concepts (Tasks 9-20). The Partnership recognizes the critical importance of measurement, monitoring, and verification technologies to support not only carbon trading but all policies and programs that DOE and other agencies may want to pursue in support of GHG mitigation. For terrestrial sequestration, research is validating best management practices for soil $\mathrm{C}$ in the Partnership region. A team of researchers from MSU have been working in the field to 
obtain field scale carbon estimates for ground truthing simulation models and identifying BMPs. Results from this research will also be used to validate the potential of soils to store carbon, and validate the Century Model predictions for soil $\mathrm{C}$ sequestration rates. Results were presented at the August 04 Partnership meeting and at the INRA Symposium in September, 2004.

Monitoring and Measurement Verification (MMV) activities, as they pertain to geological (and terrestrial) sinks, include some initial assessment of the state of the art for technologies that have a high likelihood of being mature enough to be applicable in Phase II small scale applications, and designing a risk/cost effectiveness framework to make comparative assessments of each viable sink, taking into account economic costs, offsetting benefits, scale of sequestration opportunities, spatial and time dimensions, environmental risks, and long-term viability. In conjunction with the GIS efforts and ongoing research at LANL, MSU, SDSMT, and INEEL, the Partnership is developing a well-integrated ensemble of diagnostics for MMV at each potential geological sequestration site, and a protocol for the terrestrial sequestration areas.

Regulatory and compliance research is being coordinated with the State agencies and with the IOGCC. Susan Capalbo is part of the IOGCC task force and met in Chicago in late August, 2004. A final report of the task force is due in Nov 2004. Also, the Montana Department of Environmental Quality is partnering with the Big Sky Partnership to provide detailed information on the permitting process for power plants in Montana.

The National Carbon Offset Coalition (NCOC) continued to expand the number and diversity of participants in its landowner/emitter advisory committee. Meetings were held with National Governors Association Greenhouse Gas Working Group, the Intertribal Environmental Council, and the U.S. Environmental Protection Agency. NCOC contractors attended and participated in a carbon sequestration conference sponsored by the state of Wyoming. NCOC contractors and a representative of the NCOC Board of Directors met with the Congressional delegation of the states of Montana and Idaho. NCOC contractors assisted in the development of an additional state of Montana grant designed to bring the Montana Bureau of Mines into the Partnership and expand the Partnership's geologic sequestration portion efforts. NCOC contractors worked with the Intertribal Environmental Council to develop a USDA proposal to create a 1605B Clearing House, conduct Greenhouse Gas workshops nationally with the tribes, and create a national Tribal Forestry Portfolio. Also NCOC began discussions with a national carbon trading group to begin marketing of NCOC carbon sequestration portfolios in DOE Phase II on the Chicago Climate Exchange (CCX) and other emerging markets.

Draft planning forms, contracting options and a draft forestry portfolio were submitted to the Chicago Climate Exchange for review. After review by CCX and a follow-up conference call between CCX staff and NCOC contactors a second draft is now under development

The first meeting was held with a Montana based farmer/producer group to act as an advisory committee for the development of cropland/agricultural soils protocols planning standards and contracting options this reporting period. Work has begun on the Project Planning handbooks which will ultimately incorporate all deliverables. 
During the fourth reporting period the National Carbon Offset Coalition (NCOC) continued to expand the number and diversity of participants in its landowner/emitter advisory committee. The draft NCOC Project Planning Handbook final draft was 95\% completed and distributed to members of the Partnership and others for review. Draft affiliate agreements, listing agreements, and contracting documents were completed and made ready for review by the NCOC Board of directors, the IRS. An exclusive marketing contract was completed between the NCOC, and NatSource, New York, New York to market projects in the yet to be implemented pilot portfolio. Marketing began on the first scheduled tribal workshop, in Spokane, Washington and the first private lands workshop in Post Falls, Idaho, both the week of January 11, 2005. This reporting period the University of Nebraska agroforestry subcontractor Dr. Jim Brandle completed scheduled 2004 field works.

Education and Outreach (Tasks 8, 21-25). The primary goal of the Education and Outreach efforts is to increase awareness, understanding, and public acceptance of carbon sequestration while building support for the efforts of the Partnership. The activities to date include the completion of a comprehensive Education and Outreach Plan, a Partnership listserv, the development of an internal website, development of handout materials for many of the conferences, and planning and designing outreach and education materials in conjunction with the universities and other partners throughout the States. A third Partnership meeting was held in August, 2004 followed by an AMSE symposium on carbon sequestration. Materials from these meetings and symposium are posted on our website.

As part of the ongoing efforts to involve stakeholders and communities in the carbon sequestration efforts, we are developing the decision support framework for producers to assess the soil carbon sequestration potential of specific land areas. Currently, the C-Lock program is operational for South Dakota, with expanded coverage in progress for Montana, Idaho, and Wyoming.

Other progress/efforts include: design and production of posters and fact sheets (see Appendix A); meetings with environmental groups including the Greater Yellowstone Coalition; participation in monthly Outreach conference calls; participation in the Bozeman PEIS meetings and development of Partnership materials; and design of a student-oriented ASME workshop.

An advisory committee that includes representation from local constituencies has been formed, with the first meeting tentatively planned for December, 2004. The mission and the (unofficial) composition of this committee are included in Appendix B.

\section{EXPERIMENTAL SECTION}

\section{Task 1: GHG sources}

The US EPA's Emissions Inventory Improvement Program (EIIP VIII) (USEPA 1996a and 2003a) provided the primary inventory methodology. The most recent data sources were used for each category, ranging from 1997 (most recent Census of Agriculture data) to 2002. Therefore the aggregate emissions values may be regarded as composite estimates. 
$\mathrm{CO}_{2}, \mathrm{CH}_{4}$ and $\mathrm{N}_{2} \mathrm{O}$ emissions resulting from the use of fossil energy were estimated based on the Energy Information Administration's State Energy Annual 2002 reports (USDOE-EIA 2002a). These provide detailed state-level breakdowns of fuel consumption by sector (residential, commercial, industrial, utility and transportation) and fuel type. These reports do not provide estimates of exported electricity or bunker fuels, so these categories are not included in the inventory. Standard emission factors, as described in EIIP VIII, were applied to all fuels.

$\mathrm{CH}_{4}$ emissions from oil production and transport were estimated based on state production statistics in the Petroleum Supply Annual (USDOE-EIA, 2002b). Only Montana has significant oil production, centered in its western oil fields, although a small amount is produced in South Dakota. Similarly, $\mathrm{CH}_{4}$ emissions from natural gas production and transport were estimated based on processing information from the Natural Gas Annual (USDOE-EIA, 2002c) the Oil and Gas Journal (v.101(n.22-25), 2002) and pipeline statistics obtained from the Office of Pipeline Safety (USDOT-OPS 2002). Montana has 4333 gas wells and 5 gas processing facilities, South Dakota 68 wells and Idaho has none.

\section{$\underline{\text { GHG emissions from industrial processes: }}$}

Facility-level information about industrial processes that emit $\mathrm{CO}_{2}$ and non- $\mathrm{CO}_{2} \mathrm{GHG}$ was essentially unavailable from state or corporate sources. However, process information collected from permitted entities was available for some facilities through the EPA's PCS permit database for water discharges (USEPA 2002), and the NAAQS National Emission Trends Inventory 1996 for air releases (USEPA 1996b). The South Dakota DENR made 2001 process data available for permitted industrial facilities in South Dakota; comparable data were not available from other states.

The largest industrial sources of non-energy GHGs in the region are cement and lime manufacture. According to USGS mine and processing plant location data, South Dakota has one cement plant, Montana has 2 and Idaho has one (USGS 1997). $\mathrm{CO}_{2}$ emissions estimates were based on 1996 process data from the NAAQS and 2001 data from the SD DENR. An estimate of $\mathrm{CO}_{2}$ emissions from lime calcination in the 8 lime kilns in our region was provide by Michael Miller of the USGS (personal communication).

$\mathrm{CO}_{2}, \mathrm{CH}_{4}, \mathrm{~N}_{2} \mathrm{O}$ and PFCs are generated during aluminum processing and manufacture. There is a single aluminum plant in the region, located in Montana. Production statistics were estimated based on information in the 2002 Aluminum Yearbook (Plunkert 2002).

$\mathrm{N}_{2} \mathrm{O}$ is generated during nitric acid manufacture at a single facility in Idaho; emissions were estimated based on process data from the 1996 NAAQS database. $\mathrm{CO}_{2}$ generated by soda ash consumption and $\mathrm{CO}_{2}$ manufacture, HFCs and PFCs generated during semiconductor manufacture, and $\mathrm{SF}_{6}$ released from electrical transmission and distribution equipment, were all estimated using national production statistics, state population numbers from the 2000 Census and default emission factors provided in the EIIP methodology. HCFC-22, adipic acid and SF6 from magnesium production are not significant GHG sources in these states. 
GHGs from municipal and industrial waste:

Municipal landfills that do not practice landfill gas recovery are significant aggregate sources of $\mathrm{CH}_{4}$. Landfill emissions estimates were based on state population data since 1960, and state-level waste-in-place projections derived from default per-capita landfill waste data provided in the EIIP, along with default composition factors and fractions in large vs. small landfills were obtained from the EIIP. The EPA Landfill Methane Outreach Program (USEPA 2003b) provides data regarding participating landfills in each state. Very small amounts of landfill methane were flared or recovered in Idaho and Montana as of 2002, and none in South Dakota. The EIIP also provides emission factors for municipal waste incineration facilities, of which there are 4 listed by the NAAQS database in Montana and 3 in South Dakota.

Anaerobic decomposition in municipal and industrial wastewater can generate $\mathrm{CH}_{4}$ and $\mathrm{N} 20$. Because of uneven discharge data availability, we estimated emissions from municipal wastewater based on 2002 state population data and default factors from the EIIP. The EIIP also provided regional average protein consumption estimates, necessary for $\mathrm{N}_{2} \mathrm{O}$ estimation.

Limited facility-level industrial wastewater discharge data are available through the EPA Permit Compliance System database of NPDES permits (USEPA 2002.) The EIIP provides default emission factors for three major categories of industries that generate wastewater enriched in organic constituents: fruit and vegetable processing, meat and poultry, and the pulp and paper industry. Corn-based ethanol production is also an important industry in this region, particularly in South Dakota; however, the EPA has not derived default emission factors for ethanol production. Pending better guidance, we applied the default emission factors for pulp plants to those ethanol plants which had provided discharge data to the NPDES system.

\section{$\underline{\text { GHGs from land management and livestock: }}$}

By far the most important source of GHGs in agriculture is livestock. In 2001 South Dakota and Montana ranked 6th and 9th, respectively, in overall cattle production among US states. Livestock-derived GHG emissions in South Dakota are exceeded only by emissions from the transportation sector. Enteric fermentation by ruminants is the largest source of agricultural $\mathrm{CH}_{4}$, but anaerobic management of livestock and poultry manure also produces important amounts of $\mathrm{CH}_{4}$ and $\mathrm{N}_{2} \mathrm{O}$.

We used county-level livestock population data from the 1997 Census of Agriculture (USDANASS 1997), projected to 2001, for the various livestock commodities (cattle, poultry, hogs). Census categories were adjusted to correspond to those used in the USDA annual reports referenced in the EIIP methodology, which provided management and emission factors. Countylevel estimates of $\mathrm{CH}_{4}$ and $\mathrm{N}_{2} \mathrm{O}$ emissions for cattle, hogs, poultry, horses, mules, goats and sheep were aggregated to the state level.

Large confined feeding operations (CAFOs) have been classified as point sources of water pollution and are significant $\mathrm{CH}_{4}$ sources. Because of limited facility data availability, weighted EIIP regional emission factors, which account for feed quality and likely manure management systems among the different livestock categories, were used to estimate $\mathrm{CH}_{4}$ and $\mathrm{N}_{2} \mathrm{O}$ releases 
from enteric fermentation and anaerobic manure management. None of the three Partnership states had any operational manure methane recovery systems in place as of 2003.

Burning of crop residues generates $\mathrm{CO}_{2}, \mathrm{CH}_{4}$ and $\mathrm{N}_{2} \mathrm{O}$; however, because the source is of recent biogenic origin, the $\mathrm{CO}_{2}$ is not counted in the GHG source inventory. $\mathrm{CH}_{4}$ and $\mathrm{N}_{2} \mathrm{O}$ releases were estimated based on EIIP default factors and USDA crop production statistics for 2002 (USDA-NASS 2002).

Forests can be GHG sources or sinks depending on management. We used estimates of forest stock changes from 1992-1997 and the consequent GHG fluxes derived by Birdsey and Lewis (2002). This report provides state-level estimates of forest stock changes based on USFS FIA (Forest Inventory and Analysis) data and modeling. It also includes estimates of carbon storage in persistent wood products and landfills. Methods documented in the report are consistent with those outlined for the Stock Approach in the EIIP.

Changes in soil $\mathrm{C}$ due to agricultural management will be estimated using soil, crop and management data compiled for the C-Lock program. Climate, soil and management files necessary for CENTURY modeling have been developed preliminary to conducting statewide agricultural source/sink potential estimates for Idaho, Montana and South Dakota. Historical management questionnaires sent out to Montana FSA agents to help refine CENTURY management schedules have to date resulted in a 35\% response rate. Reminders have been sent in an attempt to encourage a higher rate of response.

\section{Uncertainty Estimation for Source Estimates:}

The uncertainty inherent to the data on which our summary estimates are based was accounted for by direct Monte Carlo simulations incorporating the uncertainty ranges for major component emissions estimates. Because time and funding did not permit direct estimation of uncertainty for each emissions component, we used the DARS (Data Attribute Ranking System) scores provided by the EIIP (USEPA 1996a). DARS scores are developed by evaluating the reliability of eight components of the emissions estimates, related to the activity level and to the emission factor. Because in most cases we employed the EPA's default ("Preferred") methods for developing emissions estimates, these scores were applicable, where available.

At present there is no established functional relationship between the DARS score and statistical measures of uncertainty (such as standard deviation, SD, or coefficient of variation, CV). Therefore we established an arbitrary but conservative relationship as follows: the maximum possible DARS score is 1 (representing perfect certainty). We doubled the difference between 1 and the actual score, and used that to represent a theoretical CV from which a standard deviation could be estimated for each emission component for which DARS scores were available (representing approximately 85 percent of total emissions.)

\section{Task 1 and 2: Geological sequestration}

This section describes the research that has been initiated that supports the objectives of the Partnership under both Task 1 (1.2) and Task 2. Activities during the second, third, and fourth 
performance periods continue with the development of the methodology for characterizing the potential of subsurface formation for carbon dioxide sequestration via solubility and mineralization trapping. As noted in the first quarterly report, the approach relies upon the use of bulk whole rock chemical analyses for formation geomedia. (See references from the first report.)

The Big Sky Partnership is securing public domain information about potential geologic carbon sequestration sites, and working with industry representatives. For regional sources, we have completed the compilation of state-level aggregate data regarding emissions from fossil fuel consumption, using EIA state data. Facility-level data for energy utilities and selected industries have been compiled for South Dakota, and this will serve as a template for the other states in our Partnership. Data on $\mathrm{CH}_{4}$ from stationary and mobile combustion sources, oil and gas production, enteric fermentation and manure management, burning of agricultural wastes, and wastewater treatment, as well as data on $\mathrm{N}_{2} \mathrm{O}$ emissions from similar sources have been compiled for South Dakota. This information will be incorporated into the GIS database for the Big Sky Partnership.

During the third performance period the overall approach to conduct assessments of geologic carbon sequestration potential was further refined. We are using a two-phased approach for the assessment of regional geologic carbon dioxide sinks. The first phase is the identification of geologic "plays" that are screened against carbon dioxide injectability and capacity criteria. The screening eliminates plays that do meet minimum criteria. The remaining plays will be subjected to a detailed analysis to evaluate (using numerical hydrogeochemical modeling) their carbon dioxide trapping potential. In addition, an economic and regulatory feasibility analysis will be conducted. The results of the screening and analysis will be incorporated into a GIS database.

Also under the geological sequestration component of the Partnership work, we are reviewing geophysical methods for monitoring the pre-injection and injection (i.e., production) phases of subsurface carbon sequestration in deep reservoirs. We are reviewing methods that are applicable for (a) single-well testing as would occur with a pilot project of small scale and could occur in a larger production-scale project; (b) cross-hole testing including tomographic and timelapse tomographic methods; and (c) passive and active surface seismic monitoring or testing that can track the presence and movement of supercritical carbon dioxide.

We are also continuing to review published information on basins in the Big Sky Carbon Sequestration Partnership region. As a first step in evaluation for a familiar basin, we have reviewed published information on the western Snake River Plain as a potential geologic province for carbon sequestration and we have determined that the patchy nature of both the fluvio-lacustrine environments and the potential cap rocks on them in the basin make this province quite risky for large-scale, deep-reservoir, geologic carbon sequestration.

\footnotetext{
${ }^{1}$ The fundamental geologic unit used in the 1995 National Oil and Gas Assessment was the 'play', which is defined as a set of known or postulated oil and or gas accumulations sharing similar geologic, geographic, and temporal properties, such as source rock, migration pathways, timing, trapping mechanism, and hydrocarbon type.
} 
A meeting with researchers at Los Alamos National Laboratory (LANL) was held to discuss the availability of empirically-based reaction kinetics for carbon dioxide facilitated weathering of geologic material. This meeting resulted in an a collaborative effort to advance the state of understanding regarding carbon dioxide enhanced weathering of geologic material in potential sequestration sites. The research group at Los Alamos has developed an experimental technique through which reaction kinetics can be derived for carbon dioxide facilitated weathering of geologic materials. The application of this data to field scale sequestration modeling effort currently in progress by the Big Sky Partnership could prove invaluable to a Phase II to field deployment.

As stated in the last quarterly report, efforts have been continued to identify sources and databases containing pertinent information for the characterization of each of the plays and information relative to the screening criteria. There are two primary databases containing much of the information needed for Wyoming and Montana, 1) The Wyoming Oil and Gas Conservation Commission web site and 2) Montana Board of Oil and Gas Conservation web site. Screening criteria parameters expected to be collected from these agencies include depth, pressure, temperature, fluid properties, unit thickness, salinity, $\mathrm{pH}$, porosity, permeability, and gas content. Efforts have begun in extracting this information and organizing it into a GIS database that will show the spatial distribution of these characteristics. Other research activities are being conducted to gather the rock type and whole rock chemistry relative to each of the geologic formations within each of the plays.

During the fourth performance period, work has continued on collecting geologic properties and characteristics for the region and entering this information into an Access data base. We have discretized the Big Sky Partnership region (including Wyoming) into 10 provinces and 111 plays in accordance with the 1995 National Assessment of United States Oil and Gas Resources conducted by the U.S. Geological Survey. The effort has included incorporating data from: 1) State of Wyoming Oil \& Gas Conservation Commission, 2) Montana Board of Oil \& Gas Conservation, and 3) Montana Geological Society. The data existed both as electronic databases and hard copy information. All hard copy information was entered into the data base twice, by two different individuals, the resulting files compared, and any discrepancies identified and corrected. The resultant database includes properties that will be used to calculate the size of the various reservoirs and the potential volumes of carbon dioxide that could be contained. Our data collection activities are focused on ultimately developing a database management system coordinated with GIS capabilities to support more-detailed analysis of reservoir potential based on well, stratigraphic, engineering, and production information available from state agency sources and other sources. We have also refined our assessment approach to allow consideration of the role of ferrous iron on the mineral trapping carbon dioxide and applied our assessment approach to the volcanic basins in southwest Idaho.

We are reviewing geophysical methods for monitoring the pre-injection and injection (i.e., production) phases of subsurface carbon sequestration in deep reservoirs with an eye towards methods that are applicable for (a) single-well testing as would occur with a pilot project of small scale and could occur in a larger production-scale project; (b) cross-hole testing including tomographic and time-lapse tomographic methods; and (c) passive and active surface seismic monitoring or testing that can track the presence and movement of supercritical carbon dioxide. 
Geographic information system (GIS) work performed during the last quarter included developing a method for extracting formation information from the geologic properties and characteristics captured in various oil and gas databases from Wyoming and Montana. The geologic group is in the midst of compiling well log information that contains formation names, depths, temperatures and associated water chemistry into one comprehensive database for each of the states covered by the Partnership. As mentioned previously, the region has been discretized into 111 plays. The challenge for the GIS group is to connect the formation and chemistry data with the appropriate plays since the individual state databases do not make that distinction.

The method for connecting this data was accomplished by developing point layers representing well locations for each formation (see Figure 1). The point layers are then used to develop surfaces via kriging. Polygons representing the different plays were then used to clip out intersecting areas from the formations. Once the plays and formations were joined, the associated data from the database for each well was joined with the appropriate play.

As the final database for each of the states is completed, the method described above will be applied and the resulting layers will be provided to the geologists for screening. Screening at the play level and not the field (fields are smaller regions within each play) level, the amount of information that has to be collected is reduced significantly. Once the plays of interest are screened out, more detailed information at the field level will be collected and a similar method for connecting and the data will be performed. A more in depth discussion of these plays are included in the Appendix to this report.

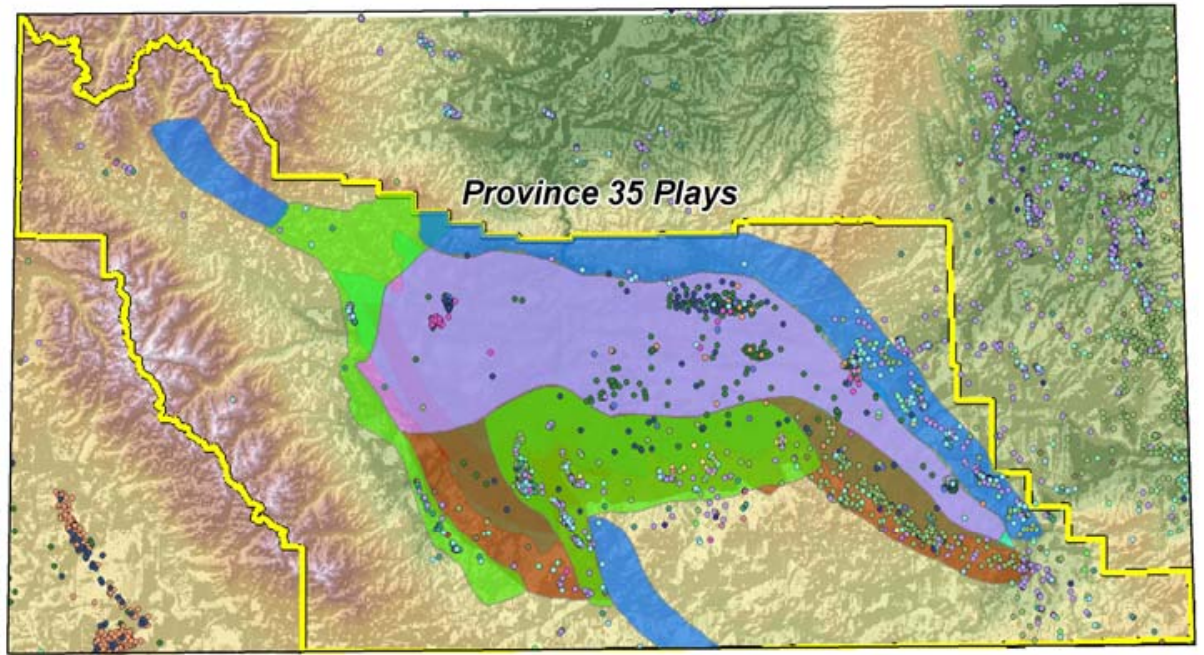

$$
\begin{array}{ll}
\text { Wells by Formation } \\
: \text { CLOVERLY } \\
: \text { CODY } \\
: \text { CROW MOUNTAIIN } \\
: \text { FORT UNION } \\
: \text { FRONITER } \\
: \text { JELM } \\
: \text { LANOTA } \\
: \text { MADISON } \\
: \text { MEETEETSE } \\
: \text { MESAVERDE } \\
: \text { MORRISON } \\
: \text { NUDDY } \\
: \text { PHOSPHORIA } \\
: \text { SUNDANCE } \\
: \text { TENSLEEP } \\
\text { - } \text { MND RIVER }
\end{array}
$$

Figure 1. Well locations by formation

\section{Tasks 4 and 5: Terrestrial sequestration}

A third area of work has been to evaluate and verify the soil C potentials with the estimates forthcoming from the Century simulation model. During the second performance period, the results of the terrestrial sinks assessment for South Dakota has been completed using the 
SSURGO soil texture grids and is being summarized; the evaluation of soil C potential on croplands in Montana is currently underway (see related material below). We have completed the SSURGO soil texture grids for Montana and Idaho; the CLIMATE data compilation is in progress.

For forested lands, the USFS data on forest carbon stocks by state, by major species is available and ready to be incorporated into the GIS database. We have been compiling NLDC time series data to determine forest area change, for use in assessing forest sink potential.

We are integrating soil and climate databases with our econometric simulation models to estimate soil carbon trajectories at the MLRA level in Montana, and to test the impact of alternative management scenarios and carbon policy scenarios on the cost of sequestering soil C and on the size of the terrestrial sinks. During the second performance period we have developed a yield based framework for using US Ag census data to predict land use changes, soil carbon changes under alternative price and climate change scenarios. The third performance period focuses on modifying and validating these empirical results. Results were presented at the May DOE carbon sequestration meeting and will be presented at the INRA workshop in September 2004.

Rangelands comprise a sizeable portion of the land resources in our Partnership region and are of critical importance to our neighboring states. Preliminary estimates suggest that rangelands can store up to an additional $0.3 \mathrm{mg} \mathrm{C} / \mathrm{ha} / \mathrm{yr}$ and restores grasslands storing nearly twice that amount. Possible options that have been identified for rangeland carbon storage to date include juniper invasion control, mesquite invasion, and cheatgrass control. These options along with baseline estimates of soil C levels at the MLRA level are being compiled by Texas A\&M colleagues for inclusion with the GIS terrestrial sink inventory.

In order to estimate areas of potential carbon sequestration or loss, data for use in a GIS is being acquired. This data includes 1990's Landsat TM data (30 m resolution) that identifies 21 classes of land cover types. For rangelands, land cover types designated as shrublands, grassland/ herbaceous, and pasture/hay are being considered. These classes will be intersected with MLRAs to define acres within each MLRA and linked with other datasets such as STATSGO soil and MODIS net primary productivity.

The terrestrial research component for rangeland is nearly complete. A summary of Natural Resources Conservation Service (NRCS) data for each of the Major Land Resource Areas (MLRAs) in the Big Sky Partnership area is included. The experimental plan includes a data collection and literature review and an evaluation of the terrestrial sink potential. These are discussed below.

A general library and Internet search was conducted primarily using Current Contents and Google. Relevant articles were entered into an EndNote database. The complete bibliography was exported into a word document that is linked to selected PDF articles and recorded on a CD. NRCS data for landuse, potential vegetation, soil, water, elevation, precipitation, temperature, and irrigation for each MLRA in the Partnership were summarized in an Excel spreadsheet 
The results of a literature search of over 1000 entrees have already been submitted in an earlier report. A revised literature search containing over 800 references linked to over 150 selected articles is being mailed as a CD. Many of the less relevant articles were removed from the original search and selected articles were linked to the bibliography which acts as an index. A summary of NRCS data for each MLRA in the Partnership is presented in Appendix C. The results of this literature review can be used to support decisions for increasing carbon sequestration for areas identified as having potential as carbon sinks. (See http://cubes.tamu.edu/bigsky)

Climatic potential, MLRA, and land tenure were selected to spatially stratify rangeland cover types into easily identifiable areas where sequestration programs could potentially be initiated. Climatic potential for carbon sequestration was classified into four categories based on annual precipitation: no potential - less than $130 \mathrm{~mm}$; low potential - 130 to $230 \mathrm{~mm}$; moderate potential - 230 to $460 \mathrm{~mm}$; and high potential - greater than $460 \mathrm{~mm}$. Since programs will not likely be implemented on Federal lands, only Indian reservations and private or other non-federal lands are discussed. For each of the Big Sky states (Idaho, South Dakota, and Montana) nonfederal land areas and Indian reservations classified as rangeland have been identified according to their potential for carbon sequestration. This information can be used to target areas that will likely have the greatest return on investments in rangeland carbon sequestration projects

A GIS approach was used to identify possible rangeland terrestrial sinks throughout the Big Sky project area. The objective was to spatially identify potential rangeland terrestrial sinks with respect to climatic potential, MLRA (as designated by the NRCS), and by land tenure (federal, private/non-federal, and Indian reservations).

Spatial cross-indexing was used to identify rangeland vegetation cover types that would have the potential for sequestration of carbon. Three major categories of cross-indexing were selected to spatially stratify rangeland cover types into easily identifiable areas where sequestration programs could be initiated. The categories of spatial cross-indexing selected included climatic potential, MLRA, and land tenure. Each of these categories and the associated spatial data used in the analysis will be described below. National land cover data from the early 1990's served as the basis for identifying rangeland land cover. This dataset and the rangeland cover types will also be described below.

Climatic Potential. To assess climatic potential for carbon sequestration, long-term precipitation was classified into the following categories:

- No Potential - Less than $130 \mathrm{~mm}$ ( $\sim 5$ inches $)$ of annual precipitation

- Low potential - 130 to $230 \mathrm{~mm}(\sim 5$ to 9 inches) of annual precipitation

- Moderate potential - 230 to $460 \mathrm{~mm}$ ( $\sim 9$ to 18 inches) of annual precipitation

- High potential - Greater than $460 \mathrm{~mm}$ (18 inches) of annual precipitation

These categories were chosen in collaboration with Dr. Joel Brown of USDA/NRCS to reflect the climatic potential for carbon sequestration and/or interventions to promote carbon sequestration on rangelands. For the No Potential category, rainfall amounts of less than 130 $\mathrm{mm}$ would be inadequate for short-term $(<10$ years) sequestration goals and also inadequate for 
interventions such as revegetation. The remaining categories represent increasing potential with areas having annual precipitation amounts greater than $460 \mathrm{~mm}$ having the greatest potential for carbon sequestration on rangelands.

The Parameter-elevation Regressions on Independent Slopes Model (PRISM) (http://www.ocs.orst.edu/prism/) long-term average annual (1970 to 2000) precipitation data (SCAS 2004) was used to spatially represent the climatic potential categories. The PRISM data is a gridded data set of total annual precipitation with a spatial resolution of approximately $4 \mathrm{~km}$. PRISM is currently used by NRCS for their climate mapping (http://www.ncgc.nrcs.usda.gov/branch/gdb/products/climate/index.html). Using the Spatial Analyst extension in ArcView 8.3, the gridded data were classified into the climatic categories described above and then converted to vector format (i.e., an ArcView shapefile). Converting the data to vector format allowed delineation of unique polygons of the climate potential categories. This was done for each of the 3 states (Idaho, Montana, and South Dakota) in the Big Sky study area (Figure 1, Figure 2, and Figure 3, respectively). (These figures can be found in Appendix C.)

Major Land Resource Areas. The NRCS defines a Major Land Resource Areas (MLRA) as "a geographic area, usually several thousand acres in extent, that is characterized by a particular pattern of soils, climate, water resources, land uses, and type of farming" (http://www.nrcs.usda.gov/ technical/land/meta/m2147.html). MLRA's form the basis of NRCS planning at national, state and regional levels. Since the NRCS will likely be a primary implementer of carbon sequestration strategies, stratification of rangelands by MLRA can provide a useful cross-index for identifying areas of high potential.

For this analysis, the MLRA boundary coverage was downloaded (ftp://fC.sc.egov.usda.gov/NHQ/pub/land/arc export/us48mlra.e00.zip) and converted to an ArcView shapefile. Using the NRCS state boundary coverage, the MLRAs within Idaho, Montana, and South Dakota were clipped from the 48 state coverage using the clip algorithm in ArcView 8.3. The resulting state MLRA maps were saved as individual shapefiles and used in the spatial analysis (Figure 4, Figure 5, and Figure 6, respectively). (See Appendix C.)

Land Tenure. Since private or non-federal land is where the majority of carbon sequestration programs are likely to be targeted, it will be important to identify the land tenure within the study area. This will assist in identifying areas that will have the greatest potential impact in carbon sequestration. To accomplish in the spatial analysis, the Federal Lands and Indian Reservations of the United States coverage was acquired (http://nationalatlas.gov/fedlandsm.html). As was done with the MLRA coverage, the individual states in the study area were extracted from the Federal Lands and Indian Reservations coverage using the clip algorithm in ArcView 8.3. The resulting map layers for Idaho, Montana, and South Dakota were saved as shapefiles and used in the spatial analysis (Figure 7, Figure 8, and Figure 9, respectively). (See Appendix C.)

Rangeland Land Cover. The 1992 National Land Cover Data (NLCD) (Vogelmann et al. 2001) was used to identify land area as rangeland. The NLCD was derived from the early to mid-1990s Landsat Thematic Mapper satellite data. Using an unsupervised clustering algorithm, land areas were classified into a 21-class land cover scheme 
(http://landcover.usgs.gov/classes.asp) applied consistently over the United States. The spatial resolution of the data is 30 meters. For this analysis, the following classes were selected as rangeland land cover types:

- Shrublands

- Grasslands/Herbaceous

- Pasture/Hay

National land cover data was distributed as TIFF images for each state. Using the Spatial Analyst extension in ArcView 8.3, the TIFF images were converted to GRID format. These grids were reclassified to extract the rangeland cover types described above. The resulting map layers for Idaho, Montana, and South Dakota (Figure 10, Figure 11, and Figure 12, respectively) were then used in the cross-tabulation analysis. (See Appendix C.)

Spatial Cross Tabulation. Within the GIS, unique polygons of climatic potential, MLRA, and land tenure were generated by intersecting these layers for each of the states in the study area. The resulting map layers (Figure 13, Figure 14, and Figure 15 - see Appendix C) were then used to cross-tabulate land area for each of the rangeland cover types by unique climatic potential, MLRA, and land tenure category. This was done using the Tabulate Areas algorithm in ArcView 3.3. For the purposes of this analysis, any land that did not have a classification of Federal or Indian reservations were given the class designation of private or other non-federal land tenure designation.

\section{Tasks 16: Terrestrial sequestration, pilot sites and simulation models}

Work is also proceeding on the terrestrial sink potential for croplands in the Big Sky region, using both pilot, field-scale methods and larger simulation type models for quantifying rates of change in soil $\mathrm{C}$ levels. Field-scale studies were established at six farm fields in the Golden Triangle in north central Montana, and researchers have been working on a weekly basis with producers in the study sites with field management and soil carbon sampling. The purpose of these studies is to determine the effect of cropping intensity (annual vs. alternate year) and tillage (conventional vs. no-till) on soil $\mathrm{C}$ levels across different soil types and terrains.

Efforts have focused on carbon measurements using the following experimental plan: At each farm, a field of 32 ha was divided into four strips ( $8 \mathrm{ha}$ ) representing the following cropping/tillage systems: traditional summer-fallow - wheat; no till chemical fallow - wheat; conventional tillage pea-wheat; and no till pea-wheat. Within each strip four sites were identified for sampling/monitoring of soil carbon changes over time. The sites (total of 16 per farm) were georeferenced via GPS. Soil samples are collected on a two-year time interval beginning with the initial background sampling in the Fall of 2002. A more detailed description of the experimental plan was included in the second quarterly report.

Field-scale studies were established at 6 farm fields in the Golden Triangle in north central Montana (Figure 2). The purpose of these studies is to determine the effect of cropping intensity (annual vs. alternate year) and tillage (conventional vs. no-till) on soil C levels across different soil types and terrains. At each farm, a field of 32 ha was divided into four strips ( 8 ha) 
representing the following cropping/tillage systems: traditional summer-fallow - wheat; no till chemical fallow - wheat; conventional tillage pea-wheat; and no till pea-wheat. Within each strip four sites were identified for sampling/monitoring of soil carbon changes over time. The sites (total of 16 per farm) were georeferenced via GPS and buried metal bolts. The sampling scheme incorporates 5 cores around a center-point forming at star-shaped pattern (Figure 3). The soil sampling scheme was adapted from the Canadian Prairie Soil Carbon Balance Project (Ellert and Bettany, 2001), and sample preparation and $\mathrm{C}$ analysis procedures were adapted from (Conant and Paustian, 2002).At sampling, each core is divided into three depths of 0-10, 10-20, and $20-50 \mathrm{~cm}$ and the core-depths surrounding each center point are bulked into a single sample. Soil samples were collected during the Fall of 2002 and 2004. In the future samples will be collected on a two-year time interval for the duration of the study (10 years).

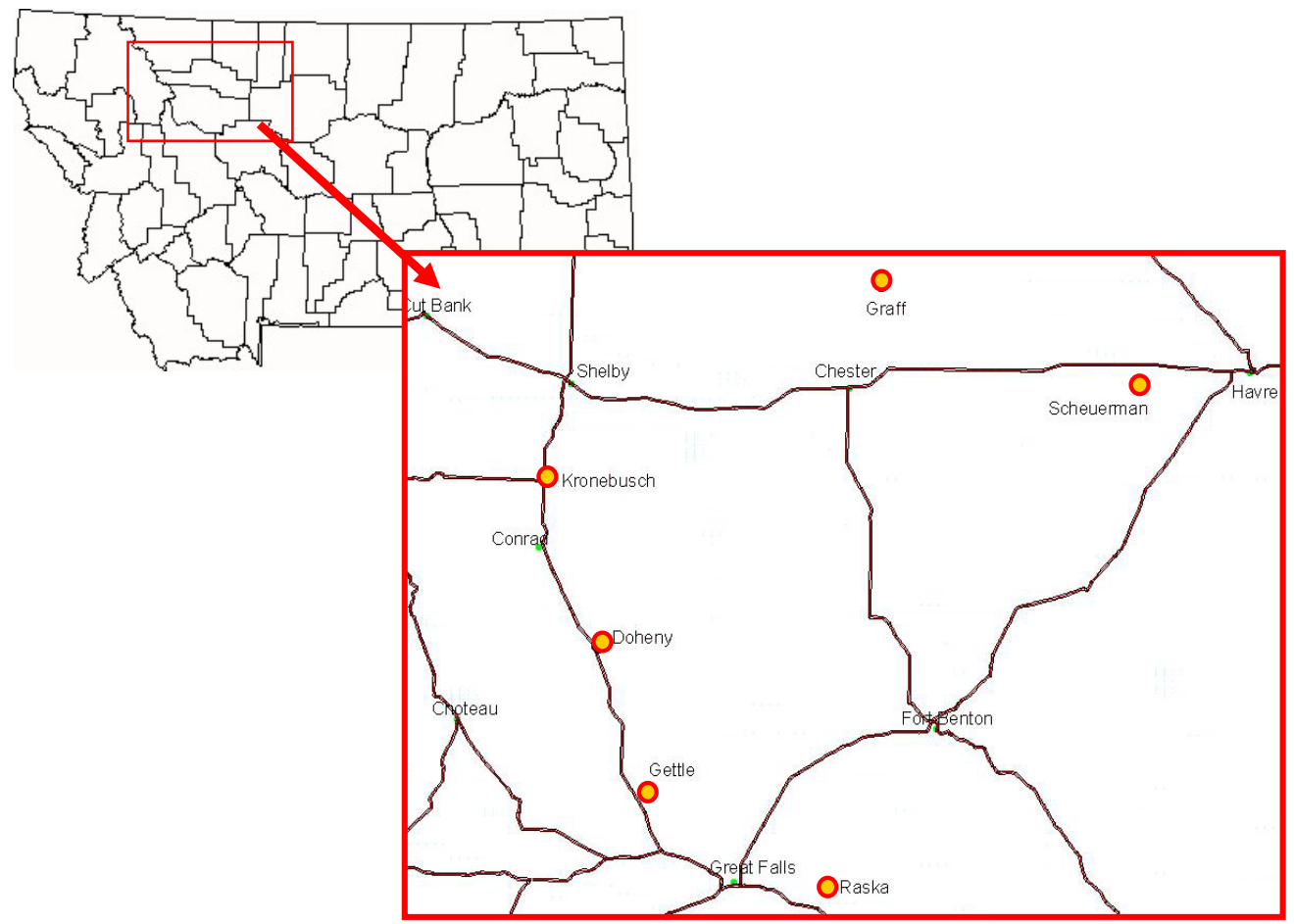

Figure 2. Locations of six farms in north central Montana for the on-farm cropping system comparisons. 


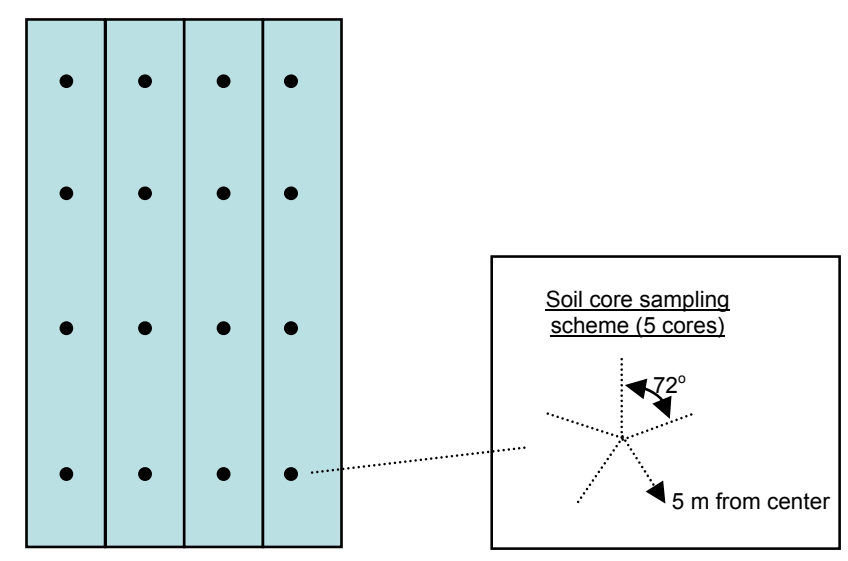

Figure 3. Hypothetical sampling scheme for long-term soil carbon studies.

Soil samples collected from this study were dried to $40^{\circ} \mathrm{C}$ then ground to pass through a $2 \mathrm{~mm}$ sieve. Subsamples were removed and ground to a fine powder using a ball mill. Total carbon analyses were performed using an automated dry combustion analyzer or Leco CNS-2000 analyzer (Leco Corporation, Saint Joseph, MI). The inorganic carbon fraction was determined using the procedure of Sherrod et al. (2002). Organic carbon was then calculated by difference, i.e. organic $\mathrm{C}=$ total $\mathrm{C}$ - inorganic $\mathrm{C}$. Nitrous oxide samples were collected using vented chamber techniques (Hutchinson and Mosier, 1981) (Figure 4). Vented soil chambers covering a $1000 \mathrm{~cm}^{2}$ area and with a $10 \mathrm{~cm}$ head-space were inserted between the crop rows. The protocol used for collecting and processing the gas samples was similar to one described by Lemke et al. (1999). Nitrous oxide flux was estimated from the concentration change in the chamber headspace over a predetermined collection period (e.g. 30 minutes to $1 \mathrm{hr}$ ). Samples were drawn from the headspace using a 20 to $30 \mathrm{~mL}$ syringe and then transferred to a pre-evacuated $13 \mathrm{ml}$ exetainer. The concentration of $\mathrm{N}_{2} \mathrm{O}$ in the sample exetainer was determined using a gas chromatograph equipped with an electron capture detector.

Intact core, crushed $(<2 \mathrm{~mm})$, and ball-milled soil samples were scanned using an ASD "Fieldspec Pro FR" VNIR spectroradiometer (Analytical Spectral Devices, Boulder, CO). This spectroradiometer has a spectral range of 350-2500 nm, $2 \mathrm{~nm}$ sampling resolution and spectral resolution of $3 \mathrm{~nm}$ at $700 \mathrm{~nm}$ and $10 \mathrm{~nm}$ at 1400 and $2100 \mathrm{~nm}$. Soils were scanned from below with a "mug lamp" foreoptic and white light source, a borosilicate bottom glass "puck" to hold samples and a Spectralon ${ }^{\circledR}$ panel for white referencing. Four and two composite scans (consisting of 10 internally averaged scans of $100 \mathrm{~ms}$ each) were obtained for the crushed and milled samples respectively, with a $90^{\circ}$ rotation between each. 

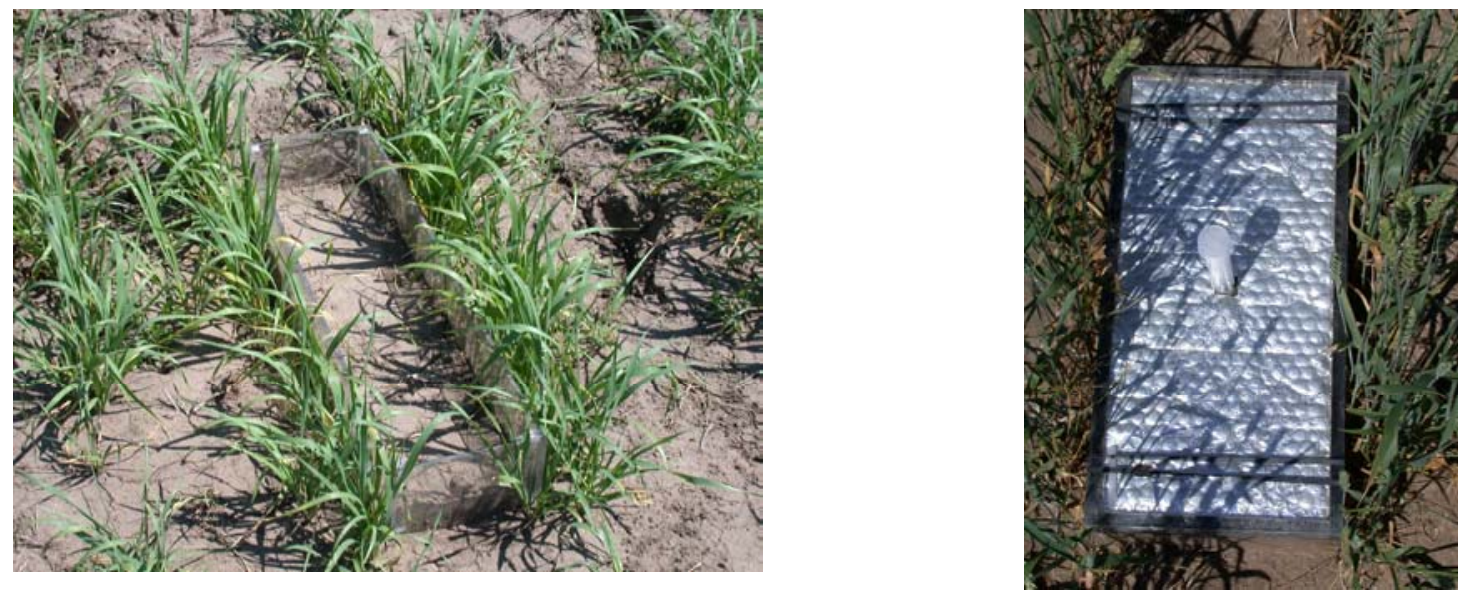

Figure 4. Nitrous oxide gas samples are collected using a vented chamber made of plexiglass. Without cover (left). With cover (right)

Efforts are nearing completion with the compilation of information relevant to point and terrestrial area sources of GHGs in MT and integration into a GIS framework as appropriate. INEEL/UI/BSU are coordinating efforts to collect spatially-referenced data for geological formations. The Partnership is assembling soil, climate, crop and land use databases and integrating these data with the C-Lock system developed by SDSMT and with economic data on land use practices and the economic frameworks developed at MSU for quantifying soil carbon sequestration potential. Furthermore, these efforts are being coordinated with the other Western partnerships.

\section{Tasks 9-20: Advanced concepts}

Task 9. Advanced concept activities this period include designing integrated measurement, monitoring, and verification for geological and terrestrial sinks, regulatory protocols, and risk assessment/tradeoff frameworks. Measurement, monitoring, and verification activities, and capture technologies, are complementing ongoing research at the labs and research institutions; to date we have assessed the focus and extent of these research efforts. The direction of the MMV research was discussed in detail the first quarterly report.

Some of the ongoing efforts at LANL on Advanced concepts include an initial examination of various mineralization concepts. These included:

1) Industrial Mineralization

2) In Situ Mineralization

3) Brine Mineralization

4) Carbonate Dissolution

5) Trona Carbonation 
All these concepts fall into the category of advanced concepts and all were found to require considerable further research and development work before they could be implemented on a practical scale and/or their long-term storage capabilities could be fully understood.

The reaction rates for industrial mineralization of $\mathrm{CO}_{2}$ are still too slow to prove to be an effective option. Although rates that can be obtained today are at the margins of becoming acceptable, achieving these rates involves still requires large (and costly) energy inputs that would prove uneconomical. New ideas and approaches are still being developed and pursued. It is believed that with further $\mathrm{R} \& \mathrm{D}$, a viable approach can be found.

The reaction rates for in-situ mineralization tend to be even lower than in the industrial mineralization case as one has very limited or no ability to achieve the most favorable operating conditions. Nonetheless, given the virtually limitless source of resources available in the region, further examination of this approach is still warranted.

Brine mineralization is appealing from a conceptual point of view especially since huge quantities of brine are available deep underground. However, the brines tend to be dominated by non reactive salts and only a very small fraction of the dissolved minerals are likely to be able to be transformed into stable carbonates without the addition of other costly chemicals. The use of any reactive chemicals other than catalysts are likely to ruled out when one considers the amount of $\mathrm{CO}_{2}$ that must be disposed of. Isolated pockets of more favorable brines could nonetheless be found.

The dissolution of calcium carbonate (limestone) in carbonic acid to form a dissolved calcium bicarbonate solution that holds down additional $\mathrm{CO}_{2}$ has been discussed in the literature. This is a process involved in the formation of limestone caves. However, the long-term fate of the temporarily dissolved $\mathrm{CO}_{2}$ is still uncertain and vast amounts of water would be required unless one were able to maintain high $\mathrm{CO}_{2}$ pressure throughout the duration of the sequestration period.

Trona carbonation is a sodium-based version of the above process and would allow one to store the $\mathrm{CO}_{2}$ in the mineral form of solid sodium bicarbonate. It has the advantage of requiring far lower $\mathrm{CO}_{2}$ pressures if the system were damp and concentrated, and no $\mathrm{CO}_{2}$ pressure if kept dry. Extensive deposits of trona exist in Wyoming, which would allow extensive storage for the region. At the same time, the deposits are too small to provide a long-term national solution.

Measurement, Monitoring and Verification (MMV) are essential functions of a successful Carbon Sequestration Program. MMV involves the implementation and deployment of various integrated measurement diagnostics that monitor geological and terrestrial sequestration sites and verify the veracity of the site's performance. A successful MMV program will require an ensemble of integrated diagnostics that monitor all aspects of sequestration as well as verify the accuracy of the diagnostics employed.

We are in the process of completing a gap analysis that will compare and contrast the current state of likely MMV diagnostics with the likely levels of $\mathrm{CO} 2$ that need to be monitored. The first step in this process is to estimate the concentration of $\mathrm{CO} 2$ one needs to monitor giving a generic geological or terrestrial sequestration scenario. Secondly, one needs to identify the 
ensemble of diagnostics that one could deploy to MMV the entire site and determine the current detection limits and sensitivity. The final step involves determining the gaps associated with the detection capabilities in the current state of the diagnostics as well as identify the technical gaps in the detection grid.

The first step involves determining the levels of $\mathrm{CO} 2$ one needs to monitor given a generic geological or terrestrial sequestration site. Some performance goals for the FutureGen geological sequestration project have been published and this is a good place to start. The FutureGen Program seeks to build a plant that will use coal to generate electricity and hydrogen while the $\mathrm{CO} 2$ produced is cleaned and permanently stored in a geological sequestration site. The goal is to annually store one million tons of CO2 and maintain a leak rate of less than $0.01 \%$ annually. This results in a total leak rate from the entire sequestration reservoir of $\sim 2 \mu \mathrm{g} / \mathrm{sec} \mathrm{CO} 2$ at this maximum level. However, the $\mathrm{CO} 2$ that leaks will likely come from several different fractures and will follow many different paths resulting in many different point sources of CO2 at the surface. Emission from each of these point sources amounts to a small fractions of the total leak rate. The challenge is to deploy diagnostics that can detect these small point sources as the $\mathrm{CO} 2$ travels from the fracture to the surface.

The second goal is to identify the likely diagnostics that will be deployed to MMV a sequestration site. Our efforts to identify these diagnostics have been divided into three subgroups including Sub-Surface, Surface and Atmospheric diagnostics. The following is a list of diagnostics that we believe need to be considered at this time.

Sub-Surface MMV:

Rock Physics

Subsurface

Cross-well Seismic

Microgravity

Downhole Sampling for Leakage, Microdrilling

Downhole Sampling for Leakage, Isotopes

Surface MMV:

Laser Induced Breakdown Spectroscopy (LIBS)

Microbial Indicators

Isotopes

Diffuse Reflectance Infrared Imaging

Atmospheric MMV:

Isotopes

LIDAR

Airborne and Satellite Remote Sensing

Multispectral \& Hyperspectral Imaging

Tunable Diode Laser Spectroscopy

We have started to investigate and document the current state of these diagnostics. For example, Ebinger et al. has determined that the detection limit of their current LIBS diagnostic is $300 \mathrm{mgC} / \mathrm{kg}$ sample. However, it is difficult to determine, at this time, how well this compares 
with the performance goals associated with terrestrial or geological sequestration. Some of the question that arise include the mechanism by which terrestrial sequestration converts atmospheric $\mathrm{CO} 2$ into soil carbon or how well will LIBS detect increases in soil carbon that may be an indication of a geological sequestration leak.

Our current effort has focused on completing the gap analysis for the surface and atmospheric diagnostics first simply because we perceive them to be easier. We have started exploring the current state of the diagnostics that are commonly used here at LANL including LIBS, Microbial Indicators, Isotopes, and Tunable Diode Lasers. We also will begin reviewing LIDAR soon. A report that will provide the detailed results of the gap analysis is being prepared as the analysis of each diagnostic is complete.

Under Advanced Concepts, we are also exploring the possibility of coupling biomass based energy production with $\mathrm{CO}_{2}$ separation and sequestration as a means of achieving net NEGATIVE $\mathrm{CO}_{2}$ emissions for the Big Sky Partnership region. This possibility is attractive due to the large quantities of biomass resource available and the region's low average population density. The region's low population density and hence $\mathrm{CO}_{2}$ production also opens the possibility of taking advantage of the large trona deposits available in Wyoming as a way to permanently sequester the $\mathrm{CO}_{2}$ through a mineralization process. The Wyoming trona deposits are estimated to be in the 50 to 100 billion ton range, capable of sequestering 10 to 20 gigatons of $\mathrm{CO}_{2}$, enough to account for all the region's emissions for some 100+ years. As the biomass being consumed has removed $\mathrm{CO}_{2}$ from the atmosphere, the region would also have 10 to 20 gigatons of $\mathrm{CO}_{2}$ credits to sell.

By using biomass, even if full $\mathrm{CO}_{2}$ separation is not achieved during power generation, the $\mathrm{CO}_{2}$ that escapes does not add to atmospheric $\mathrm{CO}_{2}$ concentrations, as the biomass fuel is already carbon neutral. The proposed approach thus removes the need for very stringent performance requirements on the $\mathrm{CO}_{2}$ separation step. Namely, any $\mathrm{CO}_{2}$ that is not separated is not a penalty, rather it just reduces the amount of $\mathrm{CO}_{2}$ credits that can be sold.

Trona is a hydrated sodium bicarbonate - sodium carbonate salt $\left(\mathrm{Na} 3 \mathrm{H}\left(\mathrm{CO}_{3}\right)_{2} \cdot 2 \mathrm{H}_{2} \mathrm{O}\right.$ or $\mathrm{NaHCO}_{3} \cdot \mathrm{Na}_{2} \mathrm{CO}_{3} \cdot 2 \mathrm{H}_{2} \mathrm{O}$ ) and is found as large evaporite deposits. When trona is reacted with $\mathrm{CO}_{2}$, the "carbonate portion" of the trona is converted to a bicarbonate, thereby sequestering $\mathrm{CO}_{2}$, i.e.

$$
\mathrm{NaHCO}_{3} \cdot \mathrm{Na}_{2} \mathrm{CO}_{3} \cdot 2 \mathrm{H}_{2} \mathrm{O}+\mathrm{CO}_{2} \quad \cdot{ }_{3} \mathrm{NaHCO}_{3}+\mathrm{H}_{2} \mathrm{O}
$$

Doing this in an aqueous process will (depending on the dilution) result in precipitates, or in fully dissolved species. The resulting solution (perhaps with precipitates entrained) could be injected downhole forming a stable chemical system provided a very low $\mathrm{CO}_{2}$ pressure $(\sim 1 / 1000$ atmospheres). At higher $\mathrm{CO}_{2}$ pressures it may be possible to fully carbonate the trona in place. Due to the mineralization of the trona, there is no concern about $\mathrm{CO}_{2}$ leakage from the system.

We have obtained samples of natural trona and verified that it is readily soluble. We have examined the thermodynamics of the carbonation reaction and verified that it should move in a forward direction. The $\mathrm{pH}$ of the resulting solution has also been examined theoretically for equilibrium conditions and should yield nearly neutral solutions. This may impact the reaction 
rate and is an issue we are currently exploring.

The main future work would be in the area of building a biomass fueled gasification plant with integral $\mathrm{CO}_{2}$ separation, and testing the trona conversion at a large scale.

Tasks 11 and 15. Market-based carbon trading research and outreach

During the reporting period the National Carbon Offset Coalition (NCOC) continued to expand the number and diversity of participants in its landowner/emitter advisory committee. Meetings were held with National Governors Association Greenhouse Gas working Group, the Intertribal Environmental Council, and the U.S, Environmental Protection Agency. NCOC contractors attended and participated in a carbon sequestration conference sponsored by the state of Wyoming. NCOC contractors and a representative of the NCOC Board of Directors met with the Congressional delegation of the states of Montana, and Idaho. NCOC contractors assisted in the development of an additional state of Montana grant designed to bring the Montana Bureau of Mines into the Partnership and expand the Partnership's geologic sequestration portion efforts. NCOC contractors worked with the Intertribal Environmental Council to develop a USDA proposal to create a 1605B Clearinghouse, conduct Greenhouse Gas workshops nationally with the tribes, and create a national Tribal Forestry Portfolio. NCOC also began discussions with a national carbon trading group to begin marketing of NCOC carbon sequestration portfolios in DOE Phase II on the CCX and other emerging markets. During the third reporting period draft planning forms, contracting options and a draft forestry portfolio were submitted to the Chicago Climate Exchange for review. After review by CCX and a follow-up conference call between CCX staff and NCOC contactors a second draft is now under development.

Work on the Project Planning handbooks will ultimately incorporate all deliverables. The work being conducted for overall objective is design of proposed protocols planning standards, and contracting options based on input from specialists in the area greenhouse gas emission reduction policy, science and the carbon market. Dr. Brandle's work on overall objective 2, the development of volume tables relies on collection of field data from previously selected sites across Montana. Field data collection is accomplished through selecting representative samples for an identified number of key species. The filed work involves actual cutting down measuring and weighing selected key species at each site. Field data is then complied into volume tables for the selected species by using existing volume tables in the region.

\section{Task 19. Assess available Measurement Instruments that can be used to Measure, Monitor and Verify Carbon Storage in Carbon Sequestration Projects}

As part of Task 19, we address problems in verifying changes in carbon stocks associated with the high cost and time involved with repeated sampling and analysis. The objective is to demonstrate the practicality of near infrared reflectance spectroscopy (NIR) as a technique for reducing the cost and time required for sample analysis. We demonstrate a technique that identifies spectrally unique samples for laboratory analysis and equation development, and compare the accuracy and cost between NIR techniques and standard laboratory procedures. Results of a general soil carbon equation built on a diverse assortment of soils collected throughout the country are presented as well as the prediction results for several carbon fractions. 
Study Site and Methods. This study was conducted on a 3000 hectare ranch in North Central Texas (Throckmorton County). Samples were collected in August 2002 and January 2003 from 175 locations distributed across the entire area of the ranch in order to capture the variance around the mean at this scale (Figure 19 - see Appendix C). For sampling protocols and NIR methodology please refer to our 2003 CASMGS report at http://cnrit.tamu.edu/casmgs/.

General Soil Equation and NIR Prediction of Carbon Fractions. We have been fortunate in having a number of collaborators who were willing to send archived soil samples analyzed for a range of constituents. The collection locations, labs and collaborators associated with the samples in the first carbon/nitrogen equation are listed in Appendix II (see Appendix C). Collaborators contributing samples with carbon fraction analysis are included in our general soils database Appendix III (see Appendix C). The carbon fractions for which NIRS equations were developed include glomalin, particulate organic matter (POM), amino sugar, $\beta$-glucosaminidase, and $\beta$-glucosidase. Additionally, an attempt was made to develop an equation for predicting bulk density. Details of equation development and sample selection can be found at http://cnrit.tamu.edu/casmgs/.

Time and Cost Comparisons: NIR vs. Conventional Laboratory. In order to estimate sampling costs, records were kept of the time required for each step in the sampling process (e.g. collecting samples, soil preparation, lab analysis, and NIR scanning steps). Estimates for conventional laboratory analysis per sample time were obtained from Cathleen McFadden from the University of Nebraska laboratory where our samples were analyzed. Because samples collected at Throckmorton Ranch contained carbonates, which require acid treatment between runs, two sample runs were included in our laboratory cost estimate.

\section{Tasks 8, 21-24: Education and outreach}

The education and outreach activities include the completion of the Education and Outreach Plan, which was revised in response to DOE and other outside review, a Partnership listserv, and the development of an internal and external website. A public website for the Big Sky Partnership was launched in the third quarter. The web site address is www.bigskyco2.org. In addition, enhanced collaboration with the University and research communities through visiting appointments, development of jointly sponsored summer schools and seminar series, presentations at international forums and at cross-departmental (USDA, EPA, DOE) conferences, and co-sponsored activities at professional meetings is underway.

\section{RESULTS AND DISCUSSION}

Task 3. GIS data compilation for Big Sky is being driven primarily by needs for analysis and modeling. Based on additional planning, the Big Sky GIS effort will focus primarily on planning and coordination, in particular 1) facilitation of GIS database implementation, 2) facilitation of multi-partner cyberinfrastructure development including links to NATCARB, 3) assistance with demonstration analyses and visualization using the database, and 4) assistance with multi-partner outreach efforts. Specific GIS planning activities to date include discussions/meeting with 
NATCARB lead Tim Carr, planning sessions via teleconference involving Big Sky GIS personnel, and coordination with SW partnership and WGA;

Geographic Information System (GIS) data have been acquired for possible geological sink areas in the Big Sky Partnership geographic area. These data were defined during the 1995 National Assessment of United States Oil and Gas Resources conducted by the U.S. Geological Survey. The National Assessment identified oil and gas producing areas at a Province or Basin scale. In the Big Sky Carbon Sequestration Partnership ten Provinces were identified.

GIS layers at the next level of resolution, 'play', were also downloaded from the USGS National Oil and Gas Assessment website. Fully compliant Federal Geographic Data Committee (FGDC) Metadata for the two sets of GIS data layers were also downloaded. These GIS data layers will be used to perform an initial assessment to determine suitability for carbon sequestration.

Task 1. Results for identification of sources indicated that Idaho, Montana and South Dakota emitted approximately 11.7, 3.0 and 10.1 MMTCE, respectively, in 2002, or 9, 3 and 13 MTCE per capita. These values span the 6.6 MTCE estimated per capita gross emissions reported in the US EPA's Emissions Inventory for 2002 (USEPA 2004). Comparable analysis will be undertaken for Wyoming in the next two quarters.

Idaho and Montana benefited from increases in forest carbon storage that offset 22 and 56\%, respectively, of their gross non-biogenic GHG emissions. Only 0.3 and $6 \%$, respectively, of these offsets were attributable to land use change, however. In South Dakota, a decline in forest biomass meant that forests were net contributors to the GHG emissions total.

In Idaho, the largest proportion of gross emissions came from the Net Electricity Imports category (54\%), followed by emissions from the transportation sector (17\%). Fossil energy consumption accounted for $85 \%$ of gross emissions, while industrial non-energy emissions accounted for less than 1 percent. Utility emissions were very small (less than 0.01 percent), due to the importance of hydroelectric power in Idaho.

By contrast, Industrial energy emissions constitute the largest single category in the Montana inventory ( $36 \%$ of gross emissions), followed by utility emissions ( $30 \%$ ) and transport emissions $(14 \%)$. Montana is a net electricity exporter, so emissions associated with exported electricity, accounting for about 24 percent of gross emissions, were deducted from the net amount. Apart from Montana's energy production industries (coal mining and oil refining), the largest nonenergy industrial emissions source is a single aluminum plant (2.6\%).

In South Dakota, Net Electricity Imports again constituted the largest single category of GHG emissions (28\%), followed by transportation (16.7\%) and utility (10.5\%) emissions. Agricultural emissions are more important in this state $(15 \%)$ than in Idaho or Montana, due to the importance of the livestock industry. A single large cement plant accounts for the largest nonenergy industrial emission (1.2\%).

In addition to state-level inventory information, SDSMT is locating large point sources of GHGs within the Partnership GIS, in order to facilitate feasibility studies of carbon capture and 
transport from major sources relative to potential geologic sinks. This process is complete for SD and underway for the other three states.

Our preliminary results for geological sinks suggest that mineral trapping for these basins will be rapid, with complete conversion of supercritical carbon dioxide to solid mineral carbonates within 400 years. This result has significant implications for the long-term containability and monitoring of a sequestration site because after a few hundred years the disposed $\mathrm{CO} 2$ will be permanently tied up in solid phases.

Tasks 4 and 5. Preliminary results for terrestrial sequestration sinks indicate that the soils in our Partnership region have the capacity to store and productively utilize more soil C. However, the potential "size" of these sinks depends upon many biophysical and economic factors and the design of the policies and programs that are in place to sequester carbon.

We now report the results for assessment of the terrestrial sequestration on rangelands, by state. (See Appendix C.)

Idaho. The cross-tabulation analysis on the land cover classes for Idaho indicated that approximately 11 million acres could be classified as rangeland cover types. Of these, approximately 7.5 million hectares were shrublands, 2.8 million hectares were grassland/herbaceous, and 0.8 million were pasture/hay cover (Table 1 - See Appendix C).

Of the land classified as rangeland types, approximately 7.1 million hectares fell under federal jurisdiction, 0.32 million were Indian Reservations, and 3.7 million hectares were private or other non-federal lands. With regard to climate potential, high climatic potential rangeland was $39 \%$ of the total rangeland area. Moderate climatic potential areas comprised $57 \%$ of the area and low climatic potential areas were only $4 \%$ of the rangeland area.

For the Major Land Resource Areas (MLRAs) within Idaho, the Northern Rocky Mountains MLRA had the greatest number of rangeland hectares at approximately 2.3 million (Table 2 See Appendix C). This was followed by the Owyhee High Plateau with 1.8 million hectares, the Easter Idaho Plateaus with 1.2 million hectares, and the Lost River Valleys and Mountains MLRA with 1.1 million hectares. The remaining 10 MLRAs had area of rangeland types less than 1 million hectares (Table 2).

Using the combination of climatic potential, MLRA, and land tenure, areas within Idaho that could be potential targets for carbon sequestration programs were identified. Since programs will not likely be implemented on Federal lands, only Indian reservations and private or other non-federal lands will be discussed. Within the High Potential areas, Indian reservations in the Eastern Idaho Plateaus (75,061 ha), the Palouse and Nez Perce Prairies (58544 ha) and the Northern Rocky Mountains (38,614 ha) MLRAs may be suitable areas for implementation of carbon sequestration programs (Table 1). On private or other non-federal land, the Eastern Idaho Plateaus (496,670 ha), Northern Rocky Mountains (310,872 ha) and the Upper Snake River Lava Plains and Hills (287, 525 ha) MLRAs had the greatest area within the high climatic potential zones (Table 1). 
Within the moderate potential zones, Indian Reservations within the Eastern Idaho Plateaus (54,189 ha), Owyhee High Plateau, (44,764 ha), and the Upper Snake River Plains (33,339 ha) MLRAs had the largest areas of land classified as rangeland types (Table 1). For private and other non-federal lands, the Upper Snake River Plains (370,495 ha) and the Central Snake River Plains (334,219 ha) MLRAs had the largest amount of rangeland when compared to the other MLRAs. It should be noted that rangeland area on Indian reservations is generally a much smaller percentage of the total area when compared to the private/non-federal lands (Table 1).

Low potential areas made up only a small percentage of the total rangeland area in Idaho (Table 1). It therefore should not be considered for carbon sequestration because of its low potential.

Montana. In Montana, the cross-tabulation analysis indicated that there was slightly over 21 million hectares of land that could be classified as rangeland (Table 3 - See Appendix C). Of this land area, approximately 3.3 million hectares was classified as shrublands, slightly over 17 million hectares as grassland/herbaceous, and approximately 0.8 million hectares as pasture and hay land (Table 3$)$. With regard to land tenure, private or other non-federal comprised approximately 14.5 million hectares of land classified as rangeland, federal land was approximately 4.8 million hectares and Indian reservations comprised approximately 2 million hectares of the rangeland land use types.

The majority of rangeland fell into the moderate climatic potential with $83 \%$ of the total rangeland area being in this class. High potential areas comprised $17 \%$ of the area, whereas low potential areas only made up $0.1 \%$ of the total rangeland area.

With regard the MLRAs within Montana, the Northern Rolling High Plains; Northern Part MLRA contained the largest area of rangeland types occupying approximately 8.6 million hectares (Table 4 - See Appendix C). This was followed by the Northern Rocky Mountains and the Brown Glaciated Plain MLRAs with each having near 3 million hectares of rangeland. In all, Montana had 12 unique MLRAs.

An examination of the rangeland area within the high climate potential, MLRA, and land tenure classes revealed several areas that could be targeted for carbon sequestration efforts. For rangeland area categorized as Indian reservations, the Northern Rocky Mountain Foothills (174,495 ha) and the Northern Rocky Mountains (145,531 ha) had the largest areas (Table 3). For private and non-federal lands, the Northern Rocky Mountains (749,855 ha), Northern Rocky Mountain Foothills (530,763 ha) and the Northern Rocky Mountain Valleys (298,990 ha) MLRAs comprised the largest rangeland areas ( $\underline{\text { Table } 3}$ ) and would likely be excellent areas to target for carbon sequestration programs.

Within the moderate climatic potential areas, the Northern Rolling High Plains; Northern Part (506,158 ha) and the Brown Glaciated Plains (398,679 ha) MLRAs had the largest area of rangeland on Indian reservations (Table 3$)$. For the private and non-federal land category, rangeland hectares were greatest for the Northern Rolling High Plains; Northern Part which comprised approximately 6.3 million acres. Although this MLRA has moderate climatic potential, development of a carbon sequestration program within this MLRA would impact approximately $30 \%$ of the rangeland in Montana. Other MLRAs that had substantial area 
included the Brown Glaciated Plain ( 1.7 million ha), the Northern Rocky Mountain Valleys ( 1.1 million ha) and the Northern Rocky Mountain Foothills (1.1 million ha) MLRAs with each having greater than a million hectares of land classified as rangeland types (Table 3 ).

As with Idaho, the low climatic potential areas made up only a small percentage of the total rangeland area in Montana (Table 3 ) and therefore, should not be considered for carbon sequestration efforts.

South Dakota. The cross tabulation analysis for South Dakota indicated that approximately 12 million hectares of land in the state could be classified as rangeland vegetation (Table 5 - See Appendix C). Grassland/herbaceous land cover occupied approximately 8.7 million hectares or $72 \%$ of the rangeland total. This was followed by the pasture/hay class with approximately 3 million hectares or $25 \%$ of the area classified as rangeland types (Table 5). Shrublands made up only about $3 \%$ of the total rangeland area.

Private or other non-federal land made up the largest portion of rangeland area in South Dakota with approximately 8.4 million hectares of land falling into this land tenure category. Indian reservations were the second with approximately 2.7 million hectares of rangeland. Federal land made up approximately 1 million hectares.

With regard to climatic potential class, rangelands falling within high climatic potential areas comprised 55\% (6.7 million ha) of the total rangeland area. Rangelands falling into the moderate climatic potential category made up $45 \%$ of the total rangeland area. No land area in South Dakota fell into the low climatic potential category.

Two MLRAs had over 35\% of all the rangeland in South Dakota within their boundaries. The Northern Rolling Pierre Shale Plains contained approximately 2.1 million hectares and the Pierre Shale Plains and Badlands contained approximately 2 million hectares of rangeland (Table 6). A total of 18 unique MLRAs occur in South Dakota.

The spatial cross-tabulation analysis identified several areas that could be targeted for carbon sequestration programs in South Dakota. In the high climatic potential regions, rangeland hectares were greatest for the Mixed Sandy and Silty Tableland (309,184 ha) and the Northern Rolling Pierre Shale Plains (238,655 ha) MLRAs within the borders of Indian reservations (Table 5). On Private and non-federal areas, the Southern Black Glaciated Plains (885,098 ha) and the Northern Rolling Pierre Shale Plains(801,423 ha) MLRAs made up the largest areas of rangelands. Three other MLRAs (Southern Dark Brown Glaciated Plains, Rolling Till Prairie and the Central Dark Brown Glaciated Plains) had approximately 500,000 hectares of rangeland within the high potential, private land category.

With regard to areas categorized as moderate climatic potential, the Rolling Soft Shale Plain (687,244 ha) and the Northern Rolling Pierre Shale Plains (387,962 ha) MLRAs had the greatest acreage with Indian reservations (Table 5). These two combine to total more than 1 million hectares. On areas categorized as private or non-federal land, two MLRAs, the Pierre Shale Plains and Badlands and the Northern Rolling High Plains; Eastern Part combine to total more than 2 million hectares of rangeland (Table 5). 
Big Sky Region Rangeland Summary. Within the Big Sky Region study area, approximately 31.5 million hectares of rangeland occur on Indian reservations and private and other non-federal lands (Table 7). The majority of this rangeland occurs under moderate climatic potential $(\sim 21$ million ha). However, approximately 10 million hectares of rangeland was classified as high climatic potential across the Big Sky region which equates to approximately $12 \%$ of the total land area in the study area. This would be a large area of impact for carbon sequestration on rangelands. Of the states within the study area, South Dakota had the largest total area of land classified as high climatic potential.

Task 16: We also provide some preliminary results from the pilot sites and analysis on terrestrial carbon in Montana's Golden triangle area. Many of the planned activities, including soil carbon analysis, assessment of diffuse reflectance infrared spectroscopy; nitrous oxide emission losses are still in progress. All farmer research partners remain actively engaged in this project and we will meet in late February to review field protocols for 2004. All farmers were interviewed in November to obtained detailed economic data about the costs and returns associated with each cropping system. This information will be used to assess net greenhouse gas emissions for each cropping system and determine cost -benefit relationships for adopting alternative cropping systems. During 2004, nitrous oxide flux measurements were collected at two field sites. Highest flux measurements were observed during May (Figure 5), and were associated with wet soil moisture conditions during this month. Results from these studies reveal that nitrous oxide emission moderate during the later part of June, and typically remain low or near background levels through the summer. If we assume a constant nitrous flux equivalent to $20 \mathrm{ug} \mathrm{N} / \mathrm{m}^{2}$ (greater than the majority of our observations), this would equate to only $0.14 \mathrm{~kg}$ of $\mathrm{N} \mathrm{ha}^{-1}$. Hence, the losses of nitrous oxide at our field sites appear nominal. Preliminary results suggest that adequate soil $\mathrm{C}$ estimations can be made using VNIR diffuse reflectance spectroscopy, provided $20 \%$ of a given sample set is submitted for regular laboratory analysis for model calibration (Figure 6). To date, these models have not proven very robust, a problem we are addressing through different modeling approaches and sample pre-treatments.

Baseline soil carbon values (Table 1) show greater variability than soil texture and $\mathrm{pH}$ values (data not shown). Statistical analysis of carbon data has not been done for we are interested in the change in soil carbon values as a function of the management treatments applied to the plots; therefore, analysis of carbon change will occur once the 2004 soil samples have been analyzed for SOC. No statistically significant differences in crop biomass were seen between treatments in 2003 (Table 2). In addition to changes in soil carbon, the agronomic effects of the treatments are also being investigated. Total biomass was measured at the same locations that soil carbon is measured. Significant differences between sites, tillage treatments, and cropping intensities were seen during the 2004 growing season (Tables 3 and 4). These differences are likely attributable to soil water status differences between treatments Differences in crop yield and quality will also be investigated; samples have yet to be threshed for yield calculation. The amount of $\mathrm{C}$ and $\mathrm{N}$ returned to the soil will be calculated for each sampling location. Economic evaluation of the 4 cropping systems at each site will be completed after farm management data have been collected in November. 
Preliminary results suggest that adequate soil $\mathrm{C}$ estimations can be made using VNIR diffuse reflectance spectroscopy, provided $20 \%$ of a given sample set is submitted for regular laboratory analysis for model calibration. To date, these models have not proven very robust, a problem we are addressing through different modeling approaches and sample pre-treatments. 

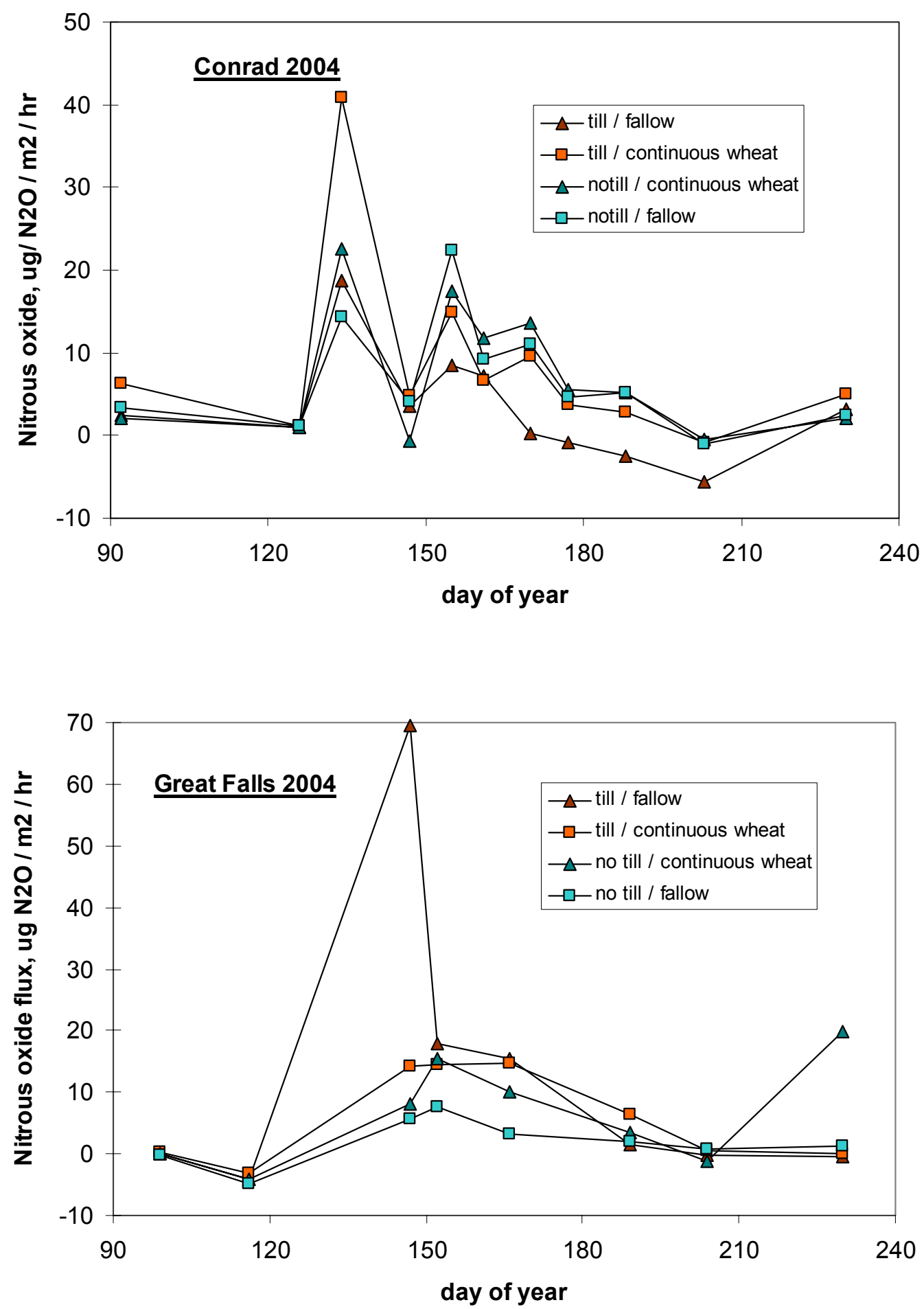

Figure 5. Seasonal distribution of $\mathrm{N}_{2} \mathrm{O}$ emissions from Conrad and Great Falls farm sites in north central Montana. 

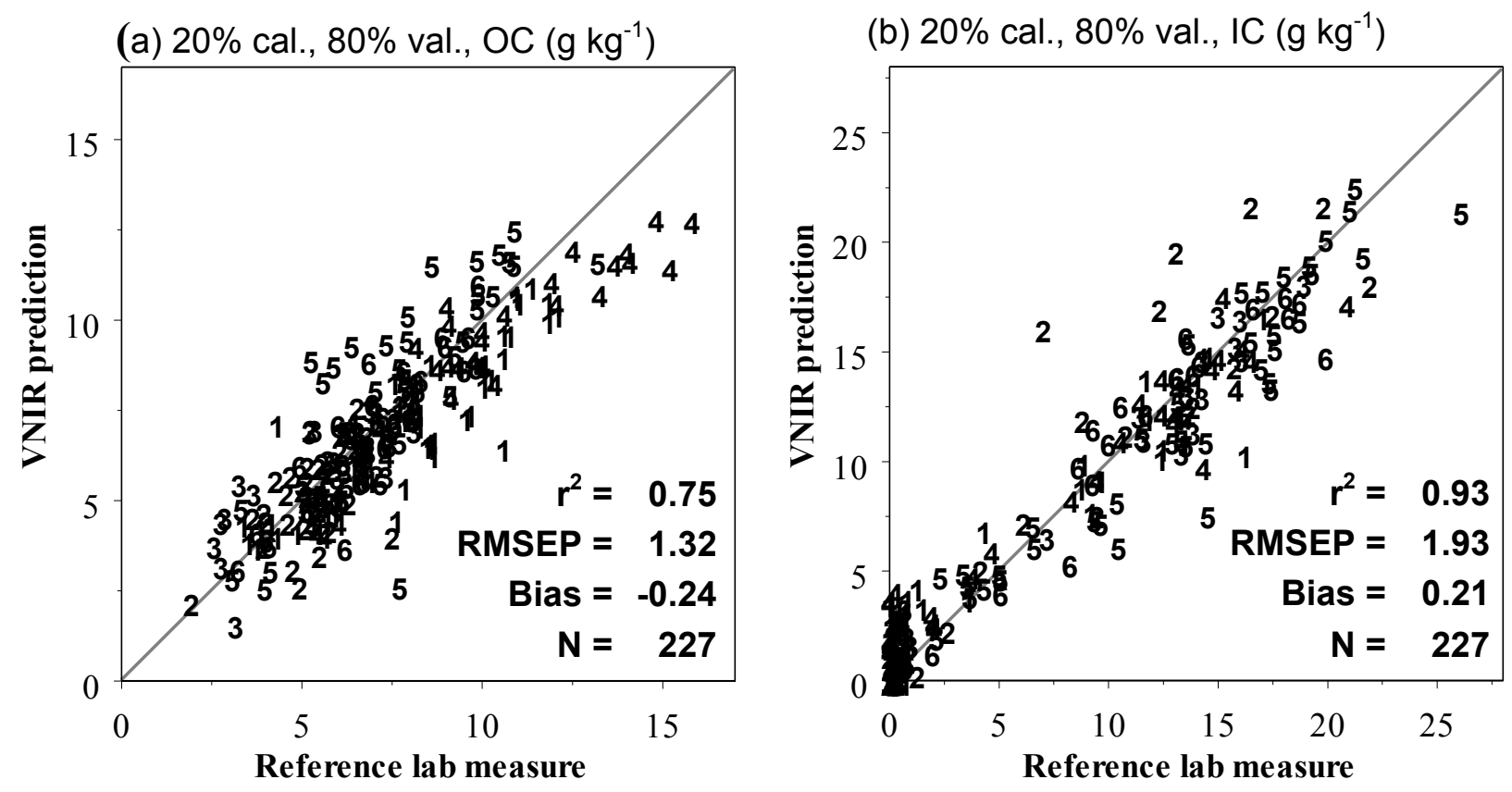

Figure 6. Predicted organic carbon (OC) and inorganic carbon (IC) using VNIR diffuse reflectance spectroscopy. 
Table 1. Soil organic carbon $\left(\mathrm{t} \mathrm{ha}^{-1}\right)$ by depth for each plot at Chester, Collins, Conrad, Great

Falls, Kremlin, and Power, Sept. - Oct., 2002.

\begin{tabular}{|c|c|c|c|c|c|c|}
\hline $\begin{array}{c}\text { Crop } \\
\text { System }\end{array}$ & Chester & Collins & Conrad & Great Falls & Kremlin & Power \\
\hline & & & & $10 \mathrm{~cm}$ & & \\
\hline Tilled F-W & 10.8 & 12.5 & 15.5 & 17.9 & 10.1 & 15.5 \\
\hline No-till F-W & 10.3 & 10.8 & 12.0 & 15.1 & 9.3 & 17.1 \\
\hline Tilled W-L & 10.2 & 11.8 & 13.3 & 14.7 & 8.3 & 14.1 \\
\hline No-till W-L & 9.9 & 10.7 & 13.3 & 18.5 & 10.8 & 11.8 \\
\hline SE & 0.3 & 0.6 & 0.7 & 1.1 & 0.4 & 0.9 \\
\hline Tilled F-W & 10.7 & 8.6 & 12.2 & 11.2 & 7.7 & 12.6 \\
\hline No-till F-W & 10.7 & 11.0 & 11.3 & 11.6 & 7.2 & 12.3 \\
\hline Tilled W-L & 10.1 & 8.8 & 11.4 & 11.8 & 7.8 & 11.7 \\
\hline No-till W-L & 10.2 & 10.3 & 11.6 & 11.8 & 6.9 & 13.6 \\
\hline SE & 1.0 & 0.6 & 0.6 & 0.4 & 0.2 & 0.5 \\
\hline Tilled F-W & 7.9 & 7.4 & 9.6 & 9.0 & 7.8 & 7.2 \\
\hline No-till F-W & 6.3 & 6.9 & 10.1 & 9.0 & 7.1 & 7.6 \\
\hline Tilled W-L & 7.6 & 8.2 & 9.3 & 8.4 & 7.5 & $10.7^{*}$ \\
\hline No-till W-L & 8.1 & 8.2 & 9.5 & 8.6 & 6.7 & 8.7 \\
\hline SE & 0.6 & 0.4 & 0.5 & 0.5 & 0.3 & 1.3 \\
\hline Tilled F-W & 6.9 & 6.5 & 8.4 & 7.4 & 4.8 & 5.5 \\
\hline No-till F-W & 6.6 & 6.3 & 7.8 & 7.3 & $3.5^{*}$ & 5.6 \\
\hline Tilled W-L & 6.8 & 5.8 & 8.2 & 7.1 & ND & 5.6 \\
\hline No-till W-L & 8.3 & 6.1 & 8.7 & 6.5 & 5.9 & 4.1 \\
\hline SE & 0.5 & 0.2 & 0.7 & 1.2 & 0.5 & 1.2 \\
\hline
\end{tabular}

$\mathrm{ND}=$ no data, samples were not able to be collected at that depth due to soil conditions.

- Values that are under review.

Table 2. Crop biomass $\left(\mathrm{t} \mathrm{ha}^{-1}\right)$ for each plot at Chester, Collins, Conrad, Great Falls, Kremlin and Power, 2003

\begin{tabular}{ccccccc}
\hline \multirow{2}{*}{$\begin{array}{c}\text { Crop } \\
\text { System }\end{array}$} & $\begin{array}{c}\text { Chester } \\
\text { peas }\end{array}$ & $\begin{array}{c}\text { Collins } \\
\text { peas }\end{array}$ & $\begin{array}{c}\text { Conrad } \\
\text { lentils }\end{array}$ & $\begin{array}{c}\text { Great Falls } \\
\text { pea/barley }\end{array}$ & $\begin{array}{c}\text { Kremlin } \\
\text { peas }\end{array}$ & $\begin{array}{c}\text { Power } \\
\text { pea/barley }\end{array}$ \\
\hline Tilled W-L & 1.5 & 1.7 & 0.8 & 4.1 & 2.3 & 2.2 \\
No-till W-L & 1.8 & 1.8 & 0.7 & 4.1 & 2.5 & 1.6 \\
Tilled F-W & ---- & ---- & ---- & ---- & ---- & --- \\
No-till F-W & ---- & ---- & --- & --- & -- & - \\
\hline
\end{tabular}


Table 3. Crop biomass $\left(\mathrm{t} \mathrm{ha}^{-1}\right)$ for each plot at Chester, Collins, Conrad, Great Falls, Kremlin and Power, 2004

\begin{tabular}{ccccccc}
\hline \multirow{2}{*}{$\begin{array}{c}\text { Crop } \\
\text { System }\end{array}$} & $\begin{array}{c}\text { Chester } \\
\text { wheat }\end{array}$ & $\begin{array}{c}\text { Collins } \\
\text { wheat }\end{array}$ & $\begin{array}{c}\text { Conrad } \\
\text { wheat }\end{array}$ & $\begin{array}{c}\text { Great Falls } \\
\text { wheat }\end{array}$ & $\begin{array}{c}\text { Kremlin } \\
\text { wheat }\end{array}$ & $\begin{array}{c}\text { Power } \\
\text { wheat }\end{array}$ \\
\hline Tilled W-L & 5.3 & 4.0 & 7.1 & 8.1 & 6.2 & 4.2 \\
No-till W-L & 5.1 & 4.5 & 7.1 & 9.6 & 6.0 & 5.3 \\
Tilled F-W & 8.1 & 6.9 & 9.3 & 12.2 & 8.5 & 3.8 \\
No-till F-W & 7.5 & 8.4 & 9.3 & 12.9 & 7.8 & 6.5 \\
\hline
\end{tabular}

$\mathrm{NT}=$ no-till; $\mathrm{T}=$ tilled; F-W = fallow wheat rotation; $\mathrm{L}-\mathrm{W}-$ lentil wheat rotation

Table 4. ANOVA results for total wheat biomass, 2004

\begin{tabular}{lcrl}
\hline Source & df & Prob>F & Effect \\
\hline Site & 5 & $<0.0001$ & \\
Tillage & 1 & 0.0019 & NT $>$ T \\
Intensity & 1 & $<0.0001$ & Fallow > Recrop \\
SxT & 5 & 0.0001 & Sites 1,2, and 5 significantly different \\
Sxl & 5 & $<0.0001$ & Sites 1,3,4,5, and 6, significantly different \\
Txl & 1 & 0.6484 & \\
SxTxl & 5 & 0.2479 & \\
\hline
\end{tabular}

1) Collins, 2) Power, 3) Chester, 4) Conrad, 5) Great Falls, and 6) Kremlin.

\section{TASK 19. Assess Available Measurement Instruments that can be used to Measure, Monitor and Verify Carbon Storage in Carbon Sequestration Projects}

Throckmorton NIRS Sample Selection and Equation Performance. Of the 460 samples that were scanned, 107 samples $(23.2 \%)$ were identified as being spectrally unique representatives of the population and were used for equation development (Figure 17 - see Appendix C), these samples along with an additional 25 randomly selected samples for validation, and 10 replicate samples for estimating the lab error were analyzed at the University of Nebraska for total carbon (TC), inorganic carbon (IC), organic carbon (OC), and total nitrogen (TN) determination. An equation for all four constituents was developed based on the 107 selected samples and used to predict the validation set of 25 samples randomly selected from the rest of the population. The validation set was then combined with the calibration set in order to increase sample number and a new equation was developed. The validation prediction results as well as the combined cross validation results are presented in Table 8 (see Appendix C).

Lab and NIR Error Comparison. A standard error of the difference (SED) analysis was used to compare lab error to NIR prediction error. This process is done by comparing the standard error of the difference between replicate lab samples $(n=10)$ and NIRS cross validation error. The SED for the lab for organic carbon was 0.301 (percent basis) and the standard error of cross validation (SECV) for NIRS was 0.313 which is 1.03 times that of the lab error. According to 
NIRS forage industry standards (WinISI handbook) NIRS predictions should be within 1.5 times that of the lab error. These results are within those limits.

In order to increase the robustness of the equation, 68 samples from a separate study on this ranch, were added to the calibration set and a final equation was developed. Since this calibration had similar RSQ and SECV values, it was used to predict the remaining 328 samples and the SECV for this equation of 0.251 was used as an estimate of the prediction error for the unanalyzed samples (Table 9 - see Appendix C).

General Soil Equation and NIR Prediction of Carbon Fractions. Two general soil carbon equations were developed based on diverse sets of samples collected throughout the country (Appendix III). The first equation presented here uses 661 samples for organic carbon and 502 samples for total nitrogen. The RSQ and SECV for organic carbon are 0.92, 0.204 and for nitrogen 0.92, 0.019 (Figure 18 and Figure 19, respectively). The locations, labs and collaborators associated with the samples in the above carbon and nitrogen equations are listed in Appendix II.

In the first equation samples with carbon or nitrogen lab value which deviated more than 1.5 standard deviations from the NIR prediction where eliminated from the equation. The results of a second equation with additional samples collected from Konza Prairie (in cooperation with Kansas State University) and using a less strict criteria (2.5 standard deviations) for removing outliers is presented in Table 10. As the number of samples in a general equation becomes very large, statistical procedures other than Partial Least Squares (PLS) regression, such as neural networks or Winisi local predictions, may become more effective for predicting unknown samples. In any case, it will always be essential that the prediction equation include samples that are spectrally similar to the samples being predicted and that the laboratory determinations of the samples used for equation development are accurate.

Carbon Fractions and Bulk Density. We are looking at carbon fractions as possible early indicators of carbon sequestration, while acknowledging that their high variability may render many of these properties inappropriate as early indicators. Results are presented for glomalin, particulate organic matter (POM), amino sugar, $\beta$-glucosaminidase, and $\beta$-glucosidase (Table 11). It is not known whether the relatively high error of prediction and low $\mathrm{R}^{2}$ is due to limited data range, poorly defined constituents, lab techniques, or NIR limitations. Further work is needed in this area.

The problem of reliable estimates of bulk density as well as rock content has not been well addressed. However, as suggested by Smith (2001), this error can be greatly reduced when measurements are focused on changes in soil carbon, rather than absolute stock - by treating rock content and bulk density as constants. Accordingly, we would recommend that until improved field measurements methods are developed for estimating rock content in rocky soils, a best possible initial estimate be made for bulk density and rock content and that this same estimate be used in subsequent samplings. The primary source could be standard published soil survey data from NRCS. 
Currently we have an NIR equation for predicting bulk density at Throckmorton with an SECV of 0.119 and $\mathrm{R}^{2}$ of 0.57 . Clearly more work is needed on reliable in-field methods for estimating bulk density as well as for organic carbon.

Time and Cost Comparison NIR vs. Conventional Laboratory. A breakdown of time per sample for collecting and preparing samples for analysis including bulk density and rock component determinations is summarized below:

Collecting and processing min./sample

Collecting samples

Separating into depth increments

8

Bulk density/moisture determination

Grinding and sieving

Calculating rock component

Total

Until in-field NIR methods are developed, the time and cost for both NIR and conventional soil collecting and preparation are identical. Here, we are concerned with comparing time per sample for conventional vs. NIR analysis. Estimates for conventional per sample time were obtained from Cathleen McFadden at the University of Nebraska laboratory. This estimate is for samples containing carbonates which require acid treatment and two sample runs.

Process Lab NIR

Sample run time (1)

Calibration time

Instrument maintenance

Sample packing (total carbon)

Treatment for organic $\mathrm{C}$

Sample packing (organic C)

Sample run time (2)

Total minutes

61.4

10.1 ( 7 minutes/day) (change lamp - 6-8 months)

Considering that there are now analyzers on the market that can do both total and organic/inorganic carbon in about 4-5 minutes and that there are also automated samplers for NIR instruments, other time estimates are possible for future analyses. For the present evaluation, we used the estimates based on the Throckmorton samples which have a difference of about 19 minutes per sample. Based on an equal labor costs $(\$ 10.00 / \mathrm{hr}$.) this would be a difference of about $\$ 3.17 /$ sample. Likely the labor cost per hour would also be less for the NIR operator because the NIR instrument can be run by a student worker with only a few minutes of instruction, where as an elemental analyzer requires a trained laboratory technician.

\section{Tasks 8, 23, 25: Outreach and education.}

A series of meetings held since the Partnership's inception has laid the foundations for assessing the issues surrounding the implementation of a market-based setting for soil $\mathrm{C}$ credits. These include the impact of existing local, state, and federal permitting issues for terrestrial based carbon sequestration projects, consistency of final protocols and planning standards with national 
requirements, and alignments of carbon sequestration projects with existing federal and state cost-share programs. These meetings provide a connection to stakeholders in the region.

The education and outreach efforts have resulted in a comprehensive plan which serves as a guide for implementing the outreach activities under Phase I. The primary goal of this plan is to increase awareness, understanding, and public acceptance of sequestration efforts and to build support for a constituent-based network which includes the initial Big Sky Partnership and other local and regional businesses and entities. Presentations about the Partnership have been made at the Western Governors' Annual meeting (June 04), the Western Energy Summit (April 04), the NETL/DOE carbon sequestration meeting (May 04), Pioneer Hi-Bred in August 04, the INRA science symposiums (Sept 04) and the American Society of Mechanical Engineers (ASME) (August 04) and in meetings with industry representatives. Fact sheets and posters were developed for these presentations (see Appendix A). PowerPoint presentations are posted on our website (www.bigskyco2.org).

The public website makes available many of the presentations to stakeholders and policy makers, provides a connection to other federal and state agencies concerned with GHG emissions, climate change, and efficient and environmentally-friendly energy production. In addition, we have laid plans for integration of our outreach efforts with the students through the ASME workshop, the film and media arts departments at MSU, and with outreach efforts at LANL. Finally, both Pam Tomski, outreach coordinator, and Susan Capalbo, PI for the Big Sky Partnership are involved in U.S.-Norway bilaterals in an effort to provide for an exchange of research and students/faculty. In related efforts, Pam Tomski organized the first U.S./Norway Summer School held at LANL in August 2004. This will be an annual event, rotating between the U.S. and Norway.

\section{CONCLUSIONS}

The Big Sky Partnership undertakes activities in four areas: evaluation of sources and carbon sequestration sinks; development of GIS-based reporting framework; designing an integrated suite of monitoring, measuring, and verification technologies; and initiating a comprehensive education and outreach program. The groundwork is in place to provide a comprehensive assessment of capture and storage capabilities for $\mathrm{CO}_{2}$ utilizing the resources found in the Partnership region (both geological and terrestrial sinks). Steps have been taken to assure that the GIS-based framework is consistent among types of sinks within the Big Sky Partnership area and with the efforts of other western DOE partnerships. The Partnership secured supplemental funding to include Wyoming in the coverage areas for both geological and terrestrial sinks and sources. This extended coverage will be the focus of the efforts in the next six months on the sources and carbon sinks.

These activities are putting in place a map-based integrated information management system for our Partnership, with transferability to the national carbon sequestration efforts. This framework will also be critically important to the evaluation of future sequestration technologies, which by necessity must utilize simulation modeling and other related techniques for assessing environmental impacts and cost effectiveness. 
The Partnership recognizes the critical importance of measurement, monitoring, and verification technologies to support not only carbon trading but all policies and programs that DOE and other agencies may want to pursue in support of GHG mitigation. The efforts begun in developing and implementing MMV technologies for geological sequestration reflect this concern. Research is also underway to identify and validate best management practices for soil $\mathrm{C}$ in the Partnership region, and to design a risk/cost effectiveness framework to make comparative assessments of each viable sink, taking into account economic costs, offsetting benefits, scale of sequestration opportunities, spatial and time dimensions, environmental risks, and long term viability. Scientifically sound information on MMV is critical for public acceptance of these technologies.

Results of research testing the feasibility of NIR technology were presented. Two general soil carbon equations demonstrate that NIR can be used to estimate soil carbon over a diverse array of soil types collected from a wide geographic area. Also, our time/cost comparisons illustrates the economic advantage of NIR technology over standard analytical methods. While NIR estimates are not as accurate as dry combustion determinations, NIR has a growing potential for in-field estimates using light-weight portable instruments. This would greatly facilitate the ease of taking larger sample numbers at more frequent intervals, which in turn, could actually improve landscape estimates of carbon stocks over traditional methods.

Finally, the education and outreach efforts have resulted in a comprehensive plan which serves as a guide for implementing the outreach activities under Phase I. The primary goal of this plan is to increase awareness, understanding, and public acceptance of sequestration efforts and to build support for a constituent-based network which includes the initial Big Sky Partnership and other local and regional businesses and entities. Presentations about the Partnership have been made at the Western Governors' Annual meeting (June 04), the Western Energy Summit (April 04), the NETL/DOE carbon sequestration meeting (May 04), Pioneer Hi-Bred (August 04), the INRA science symposiums (Sept 04) and the American Society of Mechanical Engineers (ASME) (August 04) and in meetings with industry representatives. The website makes available many of the presentations to stakeholders and policy makers, provides a connection to other federal and state agencies concerned with GHG emissions, climate change, and efficient and environmentally-friendly energy production. 


\section{REFERENCES}

Birdsey, R.A. and G.M. Lewis. 2002. Carbon in United States Forests and Wood Products, 1987-1997: State-by-State Estimates; U.S. Forest Service Global Change Research Program, sponsored by US EPA IAG DW12938264-01-0. (Available at:

http://www.fs.fed.us/ne/global/pubs/books/epa/index.html verified 16 Aug 04)

Bollinger, J., S. Hargrove, P.M. Rich, L. Brady-Sabeff, D. Collette, A. Guber, M. Klein, J.

Kuiper, J. Lee, R. Lee, K. Mickus, D. Morehouse, K. Moore, A. Ramsdell, S. Rush, J. Stewart, H. Walker, R. Wells. 2004. The DOE GIS Core Team. Annual Information Management Conference, Columbus, OH, June 9, 2004.

Conant, R.T., and K. Paustian. 2002. Spatial variability of soil organic carbon in grasslands: implications for detecting change at different scales. Environmental Pollution 116(Supp.1):127135 .

Ellert, B.H., H.H. Janzen, and B.G. McConkey. 2001. Measuring and comparing soil carbon storage, p. 676, In R. Lal and R. F. Follett, eds. Assessment methods for soil carbon. Lewis Publishers, Boca Raton, Fla.

Keating, G.N., P.M. Rich, and M.S. Witkowski. 2003. Challenges for enterprise GIS. URISA 15:23-36.

Leco Corporation. 1995. Total and organic carbon in soil, limestone similar materials. Application Bull. Leco. Corp, St. Joseph, MI

Lemke, R.L. Izaurralder, R.C., M Nyborg, and E.D. Solberg. 1999. Tillage and N source influence soil-emitted nitrous oxide in the Alberta Parkland region. Can. J. Soil Sci. 79:15-24.

Plunkert, P. 2002. Aluminium. USGS Minerals Information. http://minerals.er.usgs.gov/minerals/pubs/commodity/aluminum/alumyb024.pdf Verified 5 Aug 04).

SCAS (Spatial Climate Analysis Service) 2004, Total Annual Precipitation 1970 to 2000 for continental United States. Oregon State University. http://www.ocs.oregonstate.edu/prism/ created 4 Feb 2004.

Sherrod, L.A., G. Dunn, G.A. Peterson, and R.L. Kolberg. 2002. Inorganic carbon analysis by modified pressure-calcimeter method. Soil Sci. Soc. Am. J. 66:299-305.

Smith R.W., McLing T.L., Barrash W., Clement W.P., Erickson N.P., Geologic Sequestration of $\mathrm{CO}_{2}$ : A Uniform Strategy for Assessing Mineralization Trapping Potential Across Rock Types, Proceedings of the Third Annual Conference on Carbon Capture and Sequestration, Alexandria, VA, May 2004. 
USDA National Agricultural Statistics Service. 1997. Census of Agriculture. (http://www.nass.usda.gov/census/index1997.htm. Verified 17 Aug 04.)

USDA National Agricultural Statistics Service. 2002. QuickStats: Agricultural Statistics Data Base. (http://www.nass.usda.gov/QuickStats ; Verified 17 Aug 04.)

US DOE, Energy Information Administration. 2002a. Annual State Energy Consumption Data. (http://www.eia.doe.gov/emeu/states/_states.html. Verified 17 Aug 04.)

US DOE, Energy Information Administration. 2002b. Petroleum Supply Annual. (http://www.eia.doe.gov/oil_gas/petroleum/data publications/petroleum_supply annual/psa_vol ume2/psa_volume2.html. Verified 4 Aug 2004.)

US DOE, Energy Information Administration. 2002c. Natural Gas Annual. (http://www.eia.doe.gov/oil_gas/natural_gas/data_publications/natural_gas_annual/nga.html. Verified 4 Aug 2004.)

US EPA. 1996a. Emission Inventory Improvement Program. EIIP Document Series Vol VI, Quality Assurance Procedures and DARS Software. Chapter 4: Evaluating the Uncertainty of Emissions Estimates. (http://www.epa.gov/ttn/chief/eiip/techreport/volume06/index.html. Verified 16 Aug 04.)

US EPA. 1996b. Technology Transfer Network: Ozone Implementation.1996 National Emission Trends Data. (http://www.epa.gov/ttn/naaqs/ozone/areas/net.htm Verifed 5 Aug 04.)

US EPA. 2002. Water Discharge Permits (PCS)

(http://www.epa.gov/enviro/html/pcs/index.html. Verified 5 Aug 04)

US EPA. 2003a. Emission Inventory Improvement Program. (EIIP Document Series Vol VIII, Estimating Greenhouse Gas Emissions, Draft Version, available at http://www.epa.gov/ttn/chief/eiip/techreport/volume08; Verified 16 Aug 04).

US EPA. 2003b. Landfill Methane Outreach Program. LMOP landfill and project database, sorted by state, project status and landfill name. (http://www.epa.gov/landfill/proj/xls/lmopdata.xls. Verified 17 Aug O4.)

US EPA. 2004. Inventory of U.S. Greenhouse Gas Emissions and Sinks: 1990-2002. (http://yosemite.epa.gov/oar/globalwarming.nsf/content/ResourceCenterPublicationsGHGEmissi onsUSEmissionsInventory2004.html; Verified 19 Oct 04)

US Department of Transportation, Office of Pipeline Safety, Research and Special Programs Administration. 2002. FOIA On-Line Library: Distribution and Transmission Annuals Data for 1990-2003 (http://ops.dot.gov/DT98.htm; Verified 4 Aug 04.) 
USGS. 1997. Mine and Mineral Processing Plant Locations - Supplemental Information for USGS Map I-2654 (Arranged by State and Commodity).

(http://minerals.usgs.gov/minerals/pubs/mapdata/document3.pdf Verified 5 Aug 04)

USGS - multiple authors, 1995, 1995 National Assessment of United States Oil and Gas

Resources; U.S. Geological Survey Circular 1118, U.S. Government Printing Office,

Washington, 1995

Vogelmann, J.E., S.M. Howard, L. Yang, C.R. Larson, B.K. Wylie, N. Van Driel, 2001.

Completion of the 1990s National Land Cover Data Set for the Conterminous United States from Landsat Thematic Mapper Data and Ancillary Data Sources, Photogrammetric Engineering and Remote Sensing, 67:650-652.

Witkowski, M.S., P.M. Rich, and G.N. Keating. 2004. Enterprise GIS Design. Manuscript. 


\section{APPENDICES}

\section{APPENDICES}

A. Fact Sheet for Big Sky Carbon Sequestration Partnership, June 2004

B. Big Sky Carbon Sequestration Partnership Advisory Committee

C. Supplementary Tables and Figures

D. Agenda for Big Sky Regional Carbon Sequestration Partnership meeting, August 24-26, 2004, INEEL, Idaho Falls, ID

E. Agenda for ASME Carbon Sequestration Symposium, August 26, 2004, Idaho Falls, ID

F. Request for Supplemental DOE Support

G. Big Sky Regional Carbon Sequestration Partnership website

H. Deliverable 4 - Geologic Carbon Sequestration GIS Database Structure and Summary of Infrastructure Data Compilation and Analysis Inputs

Deliverable 9 - Terrestrial GIS Data

I. Agenda for INRA Symposium, September 21, 2004, Spokane, WA, and Abstracts of presentations given at INRA Symposium

J. National Carbon Offset Coalition brochures for January 2005 workshops (drafts)

K. News article on Carbon Cropping, Post Register, Idaho Falls, ID, August 30, 2004

L. Patent Clearance document

Appendix 1. The Northern Rockies and Great Plains Regional Carbon Sequestration Partnership MLRAs

Appendix 2. Lists of locations, sample numbers, laboratories, and contributing scientists for samples used in the first general carbon equation

Appendix 3. Soils database - listing collection locations, labs, constituents of interest and collaborators

\section{FIGURES}

Figure 1. Spatial classification of climatic potential for Idaho. Areas classified as High

Potential have greater than $460 \mathrm{~mm}$ of precipitation per year. Areas classified as Moderate Potential have between 230 and $460 \mathrm{~mm}$ of precipitation per year. Areas classified as Low Potential have between 130 and $230 \mathrm{~mm}$ of precipitation per year.

Figure 2. Spatial classification of climatic potential for Montana. Areas classified as High

Potential have greater than $460 \mathrm{~mm}$ of precipitation per year. Areas classified as Moderate Potential have between 230 and $460 \mathrm{~mm}$ of precipitation per year. Areas classified as Low Potential have between 130 and $230 \mathrm{~mm}$ of precipitation per year.

Figure 3. Spatial classification of climatic potential for South Dakota. Areas classified as High Potential have greater than $460 \mathrm{~mm}$ of precipitation per year. Areas classified as Moderate Potential have between 230 and $460 \mathrm{~mm}$ of precipitation per year.

Figure 4. Major land resource areas (MLRAs) within the state of Idaho.

Figure 5. Major land resource areas (MLRAs) within the state of Montana.

Figure 6. Major land resource areas (MLRAs) within the state of South Dakota

Figure 7. Federal lands and Indian reservations within the state of Idaho.

Figure 8. Federal lands and Indian reservations within the state of Montana. 
Figure 9. Federal lands and Indian reservations within the state of South Dakota

Figure10. Rangeland cover types for the state of Idaho as classified by the National Land Cover Database.

Figure 11. Rangeland cover types for the state of Montana as classified by the National Land Cover Database.

Figure 12. Rangeland cover types for the state of South Dakota as classified by the National Land Cover Database.

Figure 13. Sampling units (red lines) used in the spatial cross tabulation for the state of Idaho. The sampling units represent the intersection of the Major Land Resource Areas, climatic potential, and Federal Lands and Indian Reservations map coverage that were used in the spatial cross-tabulation analysis of the National Land Cover Database to determine area coverage of rangeland land cover classes (shrublands, grassland/herbaceous, and pasture/hay).

Figure 14. Sampling units (red lines) used in the spatial cross tabulation for the state of Montana. The sampling units represent the intersection of the Major Land Resource Areas, climatic potential, and Federal Lands and Indian Reservations map coverage that were used in the spatial cross-tabulation analysis of the National Land Cover Database to determine area coverage of rangeland land cover classes (shrublands, grassland/herbaceous, and pasture/hay).

Figure 15. Sampling units (red lines) used in the spatial cross tabulation for the state of South Dakota. The sampling units represent the intersection of the Major Land Resource Areas, climatic potential, and Federal Lands and Indian Reservations map coverage that were used in the spatial cross-tabulation analysis of the National Land Cover Database to determine area coverage of rangeland land cover classes (shrublands, grassland/herbaceous, and pasture/hay).

Figure 16. Distribution of sample points for Throckmorton Ranch placed over soil map and pasture boundaries.

Figure 17. Selection of spectrally unique samples used to reduce laboratory costs and to choose samples that represent the range of population variance for equation development. From a total of 460 samples (left box) this procedure identified 107 spectrally unique samples (right box).

Figure 18. NIR cross validation prediction results for organic carbon using soils diverse locations. $(\mathrm{n}=661)$

Figure 19. NIR cross validation prediction results for total nitrogen using soils diverse locations $(\mathrm{n}=502)$

\section{TABLES}

Table 1. Rangeland (ha) by land cover class and sums of the classes for Major Land Resource Area (MLRA) and land tenure class grouped according to Climatic Potential for carbon sequestration in Idaho. Percent of total reflects the percent of total rangeland occupied by the MLRA and Land Tenure class within the climatic potential grouping.

Table 2. Total hectares of rangeland cover types identified in Major Land Resource Areas (MLRA) in Idaho.

Table 3. Rangeland (ha) by land cover class and sums of the classes for Major Land Resource Area (MLRA) and land tenure class grouped according to Climatic Potential for carbon sequestration in Montana. Percent of total reflects the percent of total 
rangeland occupied by the MLRA and Land Tenure class within the climatic potential grouping.

Table 4. Total hectares of rangeland cover types identified in Major Land Resource Areas (MLRA) in Montana.

Table 5. Rangeland (ha) by land cover class and sums of the classes for Major Land Resource Area (MLRA) and land tenure class grouped according to Climatic Potential for carbon sequestration in South Dakota. Percent of total reflects the percent of total rangeland occupied by the MLRA and Land Tenure class within the Climatic Potential grouping.

Table 6. Total hectares of rangeland cover types identified in Major Land Resource Areas (MLRA) in South Dakota.

Table 7. Rangeland (ha) for each state in the Big Sky Project by climatic potential (annual precipitation) and land tenure class. Federal lands are not included since they will most likely not be included in carbon sequestration programs.

Table 8. Prediction statistics for the independent validation set predicted from the equation derived from the 107 analyzed samples and cross validation results obtained from combining the validation set with the calibration set. Values are percentages.

Table 9. Cross Validation Results for Final NIR Throckmorton Equation.

Table 10. Cross Validation Results for Second General Organic Carbon and Total Nitrogen Equation

Table 11. Cross validation predictions of selected carbon fractions. 


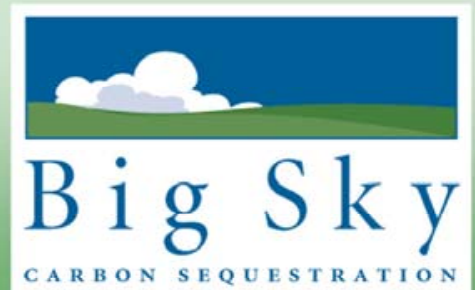
A new energy future for Montana, Idaho, south Dakota and the nation. PARTNERS H I P

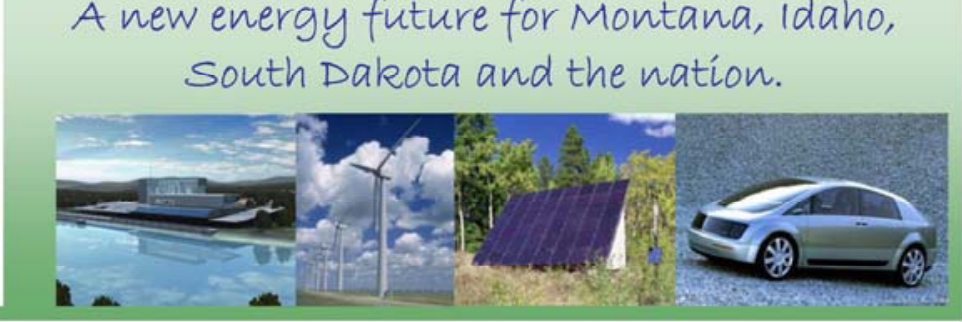

Led by Montana State University, the Big Sky Partnership is one of the U.S. Department of Energy's seven regional partnerships. To date, the Partnership includes Montana, Idaho and South Dakota, as well as contiguous parts of neighboring states and Canada. The Partnership is developing a framework to reduce carbon dioxide emissions that contribute to climate change and is working with stakeholders to create the vision for a new, sustainable

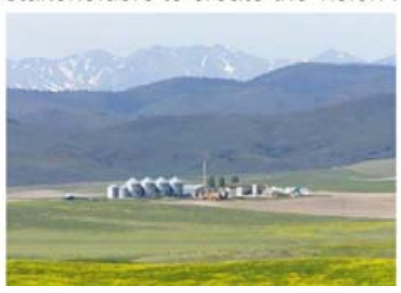
energy future that cleanly meets the region's energy needs. Because energy is not an optional commodity, carbon sequestration will play an important role.

\section{What is $\mathrm{CO}_{2}$ Sequestration?}

Carbon dioxide, $\mathrm{CO}_{2}$, is a major by-product of energy use. Abundant coal and hydropower offer Montana, Idaho and South Dakota some of the lowest cost electricity in the nation. However, burning fossil fuels for transportation, electricity generation and manufacturing emits greenhouse gases (GHG) that may impact regional and global climate. "Carbon sequestration" is a family of methods for capturing and permanently isolating gases that otherwise could contribute to global climate change. Affordable and environmentally safe sequestration approaches could offer a way to stabilize atmospheric levels of carbon dioxide.

\section{Electricity Generation \& GHG Emissions} in the Big Sky Region

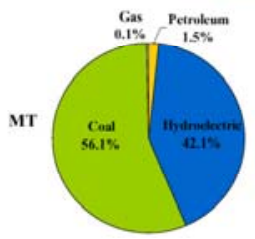

SD

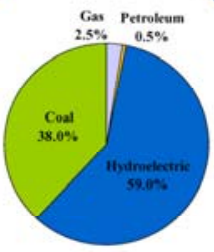

\section{Two Approaches To Carbon Sequestration}

The Big Sky Partnership is researching two major types of carbon sequestration projects: geologic and terrestrial.

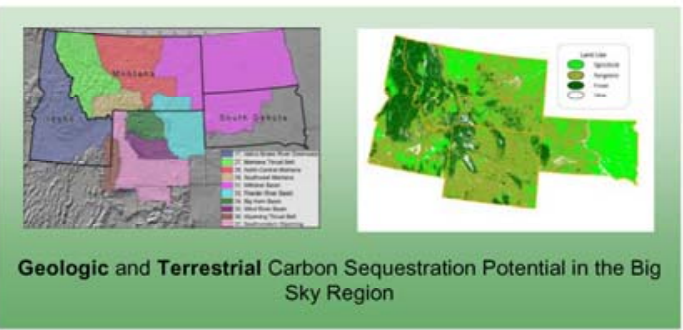

Geologic sequestration involves storing carbon dioxide in geologic formations including oil and gas reservoirs, deep saline reservoirs and coal seams. These are structures that have stored crude oil, natural gas, brine and $\mathrm{CO}_{2}$ for over millions of years. Many power plants and other large emitters of $\mathrm{CO}_{2}$ are located near geologic formations that are amenable to $\mathrm{CO}_{2}$ storage. In many cases the injection of $\mathrm{CO}_{2}$ into a geologic formation can enhance the recovery of hydrocarbons, providing value-added byproducts that can offset the cost of $\mathrm{CO}_{2}$ capture and sequestration.

Terrestrial sequestration relies on management practices of agricultural lands, rangelands, forests and wetlands to remove $\mathrm{CO}_{2}$ from the atmosphere via photosynthesis and at the same time reduce $\mathrm{CO}_{2}$ emissions. No-till or reduced till methods, increased crop rotation intensity, the use of higher residue crops, cover crops or conservation measures are all means of increasing carbon storage in agricultural soils.

Terrestrial sequestration reduces emissions while improving land and water quality, thus making soils healthier, more productive and less susceptible to largescale $\mathrm{CO}_{2}$ release. Enhancing the natural processes that remove $\mathrm{CO}_{2}$ from the atmosphere is thought to be one of the most cost-effective means of reducing atmospheric levels of $\mathrm{CO}_{2}$. 


\section{Regional Sequestration Opportunities}

The objectives of the Big Sky Partnership fall into four areas:

- Evaluation of sources and carbon sequestration sinks with the goal of identifying viable projects;

- Development of GIS-based reporting framework;

- Designing an integrated suite of measuring, monitoring and verification technologies:

- Initiating a comprehensive education and outreach program aimed at connecting with communities and organizations within the region

The region has a diverse array of geologic formations that could provide storage options for carbon in one or more of its three states. Likewise, initial estimates of terrestrial sinks indicate a vast potential for increasing and maintaining soil $\mathrm{C}$ on forested, agricultural and reclaimed lands. Both options include the potential for offsetting economic benefits to industry and society.

Complementary to the efforts on evaluation of sources and sinks is the development of the Big Sky Partnership Carbon Cyberinfrastructure (BSP - CC) and a GIS Road Map for the Partnership. These efforts are putting in place a map-based integrated information management system or carbon atlas for our Partnership with transferability to the national carbon sequestration effort.

\section{Measurement and Verification}

The Big Sky Partnership recognizes the critical importance of measurement, monitoring and verification technologies to support not only carbon trading, but other policies and programs the DOE and other agencies may want to pursue in support of GHG mitigation. The efforts begun in developing and implementing MMV (measurement, monitoring

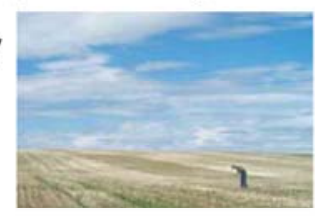
and verification) technologies for geologic sequestration reflect this concern. Research is also underway to identify and validate best management practices for soil $\mathrm{C}$ in the Big Sky region, and to design a risk/cost effectiveness framework to make comparative assessments of each viable sink, taking into account economic costs, offsetting benefits, scale of sequestration opportunities, spatial and temporal dimensions, environmental risks and long term viability.

\section{For More Information}

Please visit our website: www.bigskyco2.org or contact:

Susan Capalbo, Director and PI of Big Sky Partnership 207 Montana Hall, MSU, Bozeman, MT 59717-2460, 406-994-5619, scapalbo@montana.edu

Pamela Tomski, Big Sky Outreach Director, EnTech Strategies, LLC, 1862 Mintwood Place, NW \#101. Washington, DC, 20009, 202-822-6120 ex. 11 , ptomski@entech-strategies.com

\section{Marketing Carbon Credits}

The Big Sky Partnership is assessing the issues surrounding the implementation of a market-based setting for soil $\mathrm{C}$ credits. These include the impact of existing local, state and federal permitting issues for terrestrialbased carbon sequestration projects, consistency of final protocols and planning standards with national requirements, and alignments of carbon sequestration projects with existing federal and state cost-share programs.

\section{Connecting with the Communities and Industry}

The education and outreach efforts have resulted in a comprehensive plan whose primary goal is to increase awareness, understanding, and public acceptance of sequestration efforts and build support for a constituentbased network, which includes the initial Big Sky Partnership and other local and regional businesses and entities.

\section{The Big Sky Partnership Team}

* Montana State University

* Boise State University

* EnTech Strategies, LLC

- National Carbon Offset Coalition

- South Dakota School of Mines \& Technology

* Texas A \& M University

* University of Idaho

* Idaho National Engineering and Environmental Laboratory (INEEL)

* Los Alamos National Laboratory (LANL)

* Inland Northwest Research Alliance (INRA)

* U.S. Department of Energy

* Montana Governor's Carbon Sequestration Working Group

* The Confederated Salish and Kootenai Tribes

* Nez Perce Tribe

* The Sampson Group

* Environmental Financial Products, LLC

* Idaho Carbon Sequestration Advisory Committee (ICSAC) / Idaho Soil Conservation Committee

* Montana Bureau of Mines and Geology
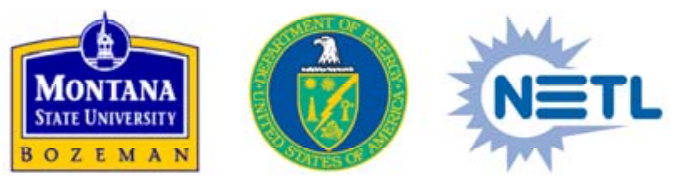


\section{Appendix B}

\section{Big Sky Partnership External Advisory Committee}

\section{Mission:}

The External Advisory Committee will:

(i) provide input on the direction and progress of the Big Sky Partnership toward meeting the goals of the Phase I efforts (Oct 03-Sept 05);

(ii) facilitate transfer of ideas and research between the Big Sky partnership and its constituencies; and

(iii) provide advice and direction to the Big Sky Partnership with respect to a Phase II proposal and work plan.

To the extent possible the Advisory Committee will meet via videoconferencing or conference calls. A progress meeting and Phase II planning workshop is tentatively planned for Spring 05. Travel expenses for the Advisory Committee will be covered by the Big Sky Partnership.

\section{Members:}

Confirmed:

Dr. Anhar Karimjee

U.S. Environmental Protection Agency

Climate Change Division

(202) 343-9260

Karimjee.Anhar@epamail.epa.gov

Mr. Ned Leonard

Assistant General Manager

Communications \& Advocacy Programs

Western Fuels Association, Inc.

Alexandria, VA 22314

(703) 684-4748

ned@,westernfuels.org

Invited:

Dr. David Wendt, Director of Jackson Hole Center for Global Affairs

Dr. Maurice J. Mausbach, Deputy Chief

Soil Survey and Resource Assessment

Natural Resources Conservation Service, USDA

Mr. Michael Jones, Puget Sound Energy, Seattle, WA

Robert Harriss

Director of the Societal Impacts group

National Center for Atmospheric Research, Boulder, Colorado

Bruce McCulloch, Sempra Energy Systems 


\section{Big Sky Partnership}

The Northern Rockies and Great Plains Regional Carbon Sequestration Partnership_MLRAs

Appendix 1

Summary of MLRA Attributes for Montana, Idaho, and South Dakota

\section{$\%$ of region MLRA NAME}

10 Upper Snake River Lava Plains and Hills (10A proposed)

11 Snake River Plains (11A and 11B proposed)

12 Lost River Valleys and Mountains

13 Eastern Idaho Plateaus

43 Northern Rocky Mountains

44 Northern Rocky Mountain Valleys

$1 / 2$ north

Northern Rocky Mountain Foothills

52 Brown Glaciated Plain

2/3 west $\quad 53$ A Northern Dark Brown Glaciated Plains

1/3 south $\quad 53$ B Central Dark Brown Glaciated Plains

53 C Southern Dark Brown Glaciated Plains

54 Rolling Soft Shale Plain

55 C Southern Black Glaciated Plains

58 A Northern Rolling High Plains; Northern Part

$1 / 2$ south $\quad 58 \mathrm{D}$ Northern Rolling High Plains; Eastern Part

$60 \mathrm{~A}$ Pierre Shale Plains and Badlands

60 B Pierre Shale Plains; Northern Part

61 Black Hills Foot Slopes

62 Black Hills (home of Rocky Racoon)

63 A Northern Rolling Pierre Shale Plains

$1 / 2$ north

$1 / 3$ north

$1 / 2$ west
66 Dakota-Nebraska Eroded Tableland

102 A Rolling Till Prairie

102 B Till Plains
Area $\mathbf{k m}^{2}$ Area $\mathbf{m i}^{2}$ States

44,870 17,330 Idaho and Oregon

$35,250 \quad 13,610$ Idaho and Oregon

16,380 6,320 Idaho

$21,010 \quad 8,110$ Idaho

282,650 109,130 Idaho, Montana, Oregon, Washington, and Wyoming

32,320 12,480 Idaho, Montana, and Washington

52,070 20,110 Montana and Wyoming

52,110 20,120 Montana

30,740 11,870 Montana and North Dakota

44,980 17,370 North Dakota and South Dakota

13,870 5,350 South Dakota

$58,100 \quad 22,430$ Montana, North Dakota, and South Dakota

20,240 7,810 South Dakota

105,620 40,780 Montana and Wyoming

10,000 3,860 North Dakota and South Dakota

23,600 9,110 Nebraska, South Dakota, and Wyoming

$5,600 \quad 2160$ Montana

8,400 3,240 South Dakota and Wyoming

9,200 3,550 South Dakota and Wyoming

29,610 11,430 South Dakota

28,400 10,970 Nebraska, South Dakota, and Wyoming

12,400 4,800 Nebraska and South Dakota

38,600 14,900 Minnesota and South Dakota

43,790 16,910 lowa, Minnesota, South Dakota, and Nebraska 


\section{Land use}

$3 / 5$ federal, $90 \%$ range, $5 \%$ (along streams) irrigated for potatoes, small grains, pasture

$1 / 2$ federal - mostly range, annual grasses have invaded much of the rangeland, 1/4 irrigated potatoes mostly all federal, high mountain slopes are forested, grass - shrubs on slopes and valleys are grazed $1 / 4$ federal, $1 / 2$ range, $1 / 4$ dryfarm - wheat, $\sim 10 \%$ irrigated -alfalfa, $\sim 10 \%$ forested $\mathrm{mt}$. slopes

Nearly all this area is federally owned, less than $2 \%$ cropped, Mostly forest -lumbering and mining

farms and ranches. 1/2-1/3 native range (grass-shrub) , 1/3 irrigated - Potatoes, sugar beets, and peas

$1 / 5$ federal, $1 / 2$ range of short and mid grass, $1 / 5$ dryfarm (northeast side) wheat

Most of the land in the east is in range/ one-half of the total area is cropped (west) spring wheat

$1 / 2+$ dryland farm mostly spring wheat / sloping soils are in native grass range

$1 / 2+$ is dryfarmed -.winter wheat chief cash crop. Corn, grain, sorghum, oats, and alfalfa also grown sloping soils are in range.

$2 / 3$ dryland Spring wheat is the chief crop / flax, oats, barley, and alfalfa also grown / more sloping soil in native grass range

$1 / 3$ dry frarmed wheat/ $3 / 5$ native grass and shrub grazed/

$70 \%$ dryland farm.- Corn, small grains, and alfalfa main crops / 1/4 native range and tame pasture alone steeper slopes

Most in native grasses and shrubs grazed by cattle and sheep / rest dryland farming in wheat / sugar beets, alfalfa along river

$4 / 5$ ranches in native grasses and shrubs grazed by cattle and sheep $10-15 \%$ dryland wheat and alfalfa

Most of it is in native grasses and is used for grazing livestock / Badlands National Monument is a large tourist attraction.

Most of it is rangeland used for grazing livestock

Native grass is used mainly for livestock grazing. / the less sloping parts are farmed mainly to alfalfa and small grains

Black Hills National Forest used for mining, recreation, and hunting./Some timber / summer grazing

area is used mainly for livestock production and cash-grain farming / Dry-farming soils not suited to cultivation is destroying the native grassland $3 / 5$ rangeland cattle / 1/3 crop cash grain and winter wheat / corn and sugar beets are irragated crops

Most of this area is in native grasses that are grazed by cattle

$70 \%$ is cropland Corn, soybeans, alfalfa, flax, spring wheat, and oats are the principal crops /

$70 \%$ cropland Corn, soybeans, grain sorghum, alfalfa, and oats are the principal crops./ Urban development is expanding 


\section{Elevation}

400 to $2,000 \mathrm{~m}$

600 to $1,700 \mathrm{~m}$

$1,400 \mathrm{~m}$ valleys to $3,100 \mathrm{~m}$ mt.crests.

1,400 to $2,000 \mathrm{~m}$ plains and plateaus

400 to $2,400 \mathrm{~m}$

600 to as much as $2,100 \mathrm{~m}$

1,100 to $1,800 \mathrm{~m}$ in north

600 to $1,400 \mathrm{~m}$

600 to $900 \mathrm{~m}$

400 to $700 \mathrm{~m}$

500 to $600 \mathrm{~m}$

500 to 1100 east to west

400 to 600

900 to $1,800 \mathrm{~m}$ east to west

700 to $1,000 \mathrm{~m}$ east to west

800 to $1,100 \mathrm{~m}$

900 to $1,000 \mathrm{~m}$ on uplands

900 to $1,200 \mathrm{~m}$

1,100 to $2,000 \mathrm{~m}$

400 to $500 \mathrm{~m}$ bottom 500 to $900 \mathrm{~m}$ upland 900 to $1,200 \mathrm{~m}$

600 to $900 \mathrm{~m}$

300 to $400 \mathrm{~m}$ lowlands 400 to $500 \mathrm{~m}$ uplands 300 to $400 \mathrm{~m}$ bottpm 400 to $500 \mathrm{~m}$ uplands
Precipitation

250 to $500 \mathrm{~mm}$.

175 to $325 \mathrm{~mm}$

175 to $275 \mathrm{~mm}$ valleys $625 \mathrm{~mm}$ mountains

300 to $625 \mathrm{~mm}$

625 to $1,525 \mathrm{~mm}$

300 to $400 \mathrm{~mm}$ in most of the area

300 to $500 \mathrm{~mm}$

250 to $375 \mathrm{~mm}$

300 to $350 \mathrm{~mm}$

425 to $475 \mathrm{~mm}$

350 to $425 \mathrm{~mm}$

325 to 450

50 to $525 \mathrm{~mm}$

300 to $500 \mathrm{~mm}$

325 to $375 \mathrm{~mm}$

300 to $400 \mathrm{~mm}$

300 to $350 \mathrm{~mm}$

375 to $450 \mathrm{~mm}$

450 to $650 \mathrm{~mm}$

375 to $475 \mathrm{~mm}$

375 to $450 \mathrm{~mm}$

450 to $550 \mathrm{~mm}$

500 to $600 \mathrm{~mm}$

500 to $650 \mathrm{~mm}$
Temperature

4 to $13 \mathrm{C}$

5 to $11 \mathrm{C}$

3 to $7 \mathrm{C}$ valleys

4 to $7 \mathrm{C}$

4 to $8 \mathrm{C}$

6 to $7 \mathrm{C}$

3 to $7 \mathrm{C}$

3 to $5 \mathrm{C}$

7 to $9 \mathrm{C}$

1 to $7 \mathrm{C}$

4 to $7 \mathrm{C}$

7 to $9 \mathrm{C}$

4 to $7 \mathrm{C}$

4 to $7 \mathrm{C}$

7 to $9 \mathrm{C}$

4 to $7 \mathrm{C}$

6 to $9 \mathrm{C}$

3 to $7 \mathrm{C}$

7 to $9 \mathrm{C}$

7 to $9 \mathrm{C}$

8 to $10 \mathrm{C}$

6 to $9 \mathrm{C}$

9 to $11 \mathrm{C}$
Freeze free days

60 to 165 days

90 to 170

80 to 110 days valleys

50 to 120

45 to 120 days

100 to 120 days

90 to 125 days

100 to 130

110 to 125 days

130 to 150 days

110 to 130 days

110 to 135

130 to 155 days

120 to 140 days

120 to 130 days.

130 to 150 days

110 to 125 days

110 to 140 days

80 to 130 days

130 to 160 days

$\sim 140$ days.

130 to 160 days

120 to 140 days

135 to 165 days 
Water

supplies small mostly untapped - low to moderate precipitation is adequate for dryfarming

Ground water is plentiful around major rivers - scarce on sites far from the major rivers

moderate precipitation for grass/shrubs on slopes, valleys depend on the streamflow

limited amount precip. for dryfarming and grazing

Moderate precipitation and many perennial streams and lakes provide ample water Perennial streams principle source.

Presipitation too low for crops in some parts/ adequate for grain and forage in others Most of the area depends on precipitation for water for range and crop

mostly moisture is inadequate for good crop production /

Most years, moisture is inadequate for maximum crop production.

most years moisture is inadequate for maximum crop production

most years moisture is inadequate for maximum crop production

most years precipitation is inadequate for maximum crop production

low and erratic precipitation is the principal source of water for agriculture.

low and erratic precipitation is the principal source of water for agriculture

limited precipitation, production of cultivated crops is marginal.

limited precipitation, the growing of cultivated crops is marginal

Most of the soils suitable for cultivation are dry during much of the growing season.

Precipitation, perennial streams, springs, and shallow wells provide adequate water for domestic use

In most years precipitation is inadequate for maximum plant growth

Most of the area depends on the rather low and erratic precipitation for water

limited precipitation makes farming a risk

In many years precipitation is inadequate for maximum production

Precipitation is the principal source of moisture for crops some year it is inadequate

\section{Irrigation}

Streams provide enough irrigation water along the major valleys ground water around major rivers is used extensively for irrigation about $1 \%$ mostly for hay and pasture

Ground water is scarce except near the large streams

Streams and reservoirs supply water to adjoining MLRA's for irrigation Ground water is abundant some used for irrigation

$1-2 \%$ irrigated (valleys) major rivers provide most water for irrigation The Milk River provides irrigation water to its flood plains

only a small acreage is irrigated by the Missouri river

irrigated cropland is mostly along a narrow band of the Missouri river only a small acreage is irrigated around the Missouri river irrigation is available in quantity only from the Missouri River Water from reservoirs on the Missouri River is used for irrigation

Strips along the Yellowstone River and main tributaries are irrigated. no irrigation some wells provide water for stock

Few places have shallow-water wells for domestic use.

Water for livestock comes mainly from runoff that flows into dams

Domestic wate mostly from $f$ streams, shallow wells, and springs.

moisture is adequate for normal plant growth. No irrigation reservoirs on the Missouri River are on the eastern border Ground water is scarce and of poor quality in most of the area

The Niobrara River is the only perennial stream.

Shallow wells iand small ponds principle water supply for for livestock irrigation is increasingly along major rivers 


\section{Dominat soil}

Xerolls and Argids moderately fine textured to fine textured

Orthids, Argids, and Orthen

Orthids, Orthents, Aquolls, and Xerolls (valleys)

Xerolls and Borolls

Ochrepts and Andepts

Orthids, Borolls, and Argids medium to fine textured

Borolls, Orthents, and Fluvents medium to fine textured

Borolls, Orthents, Argids, and Fluvents medium to fine textured

Borolls. deep, well drained, and medium textured

Ustolls. They are deep, well drained, and medium textured

Borolls. They are deep, well drained, and medium textured

Borolls. moderately deep - deep, loamy and clayey

Ustolls. deep, well to moderately well drained, sandy to clayey.

Orthents, Orthids, Argids, Borolls, and Fluvents. medium to fine textured, shallow to deep

Orthents, Orthids, Argids, and Borolls. They are medium to fine textured and well drained

Orthids. They are moderately deep and deep and fine textured

Orthids and Orthents. They are moderately deep and deep and fine textured

Orthents. They are deep to shallow and fine textured to medium textured

Boralfs. They have a frigid or cryic temperature regime

Ustolls and Orthents fine textured and very fine textured

Ustolls. They are medium textured and formed in loess or in alluvium

Ustolls. moderately and deep, medium and moderately coarse textured

Borolls. They are deep and loamy and silty

Ustolls. They are deep and silty and loa

\section{Vegetation type}

shrub-grass association

shrub-grass vegetation

desert shrub, shrub-grass, and forest vegetation

grass-shrub vegetation

conifer forests

conifer forests and grassland vegetation

grass valleys/foothills, forest higher elevations

grass land vegetation

natural prairie vegetation

natural prairie vegetation

natural prairie vegetation

natural prairie vegetation

natural prairie vegetation

grassland vegetation

mixed prairie vegetation

natural mixed prairie vegetation

natural mixed prairie vegetation

open grassland, forest, and savanna vegetation

open to dense forest vegetation

transition between mixed and true prairie vegetation.

mixture of short, mid, and tall grasses

mixed prairie vegetation

true prairie vegetation

true prairie vegetation 


\section{Potential Vegetation}

Big sagebrush and bluebench wheatgrass are dominant on moderate to deep soils

Big sagebrush, winterfat, shadscale, Indian ricegrass, needleandthread, Thurber needlegrass, and Sandberg bluegrass grow on the lower Snake River Plains

Indian ricegrass, needleandthread, shadscale, gardner saltbush, and scarlet globemallow are major species in the valleys

Bluebunch wheatgrass and big sagebrush are dominant.

western white pine, ponderosa pine, lodgepole pine, western redcedar, western larch, hemlock, Douglas-fir, subalpine fir, and spruce are common

Bluebunch wheatgrass, rough fescue, Idaho fescue, and bearded wheatgrass are the major species of the grassland

Bluebunch wheatgrass, rough fescue, Idaho fescue, and western wheatgrass are the major grass species /Ponderosa pine, Rocky Mountain juniper higher up

Bluebunch wheatgrass, needleandthread, western wheatgrass, green needlegrass, and basin wildrye are dominant species.

western wheatgrass, needleandthread, green needlegrass, and blue grama. Little bluestem / important species on sloping and thin soils

Western wheatgrass, blue grama, needleandthread, and green needlegrass are dominant species

western wheatgrass, needleandthread, green needlegrass, and blue grama Little bluestem important on sloping thin soils

Western wheatgrass, blue grama, needleandthread, and green needlegrass are dominant species / Prairie sandreed and little bluestem on shallow soils

western wheatgrass, green needlegrass, needleandthread, and porcupinegrass. Big bluestem is an important species on soil with restricted drainage

Western wheatgrass, bluebunch wheatgrass, green needlegrass, and needleandthread are dominant species /in east littlebluestem replaces bluebunch wheatgrass

western wheatgrass, green needlegrass, blue grama, and buffalograss /Little bluestem and sideoats grama grow on shallow soils

western wheatgrass, green needlegrass, blue grama, and buffalograss /Little bluestem and sideoats grama grow on shallow soils

western wheatgrass, green needlegrass, and blue grama. Little bluestem and sideoats grama grow on shallow soils.

little and big bluestem, green needlegrass, western wheatgrass, and needleandthread / Bur oak grows throughout the area

Black Hills spruce grows at higher elevations // Kentucky bluegrass, poverty oatgrass, Richardson needlegrass, and Canada wildrye are common under story grasses

Green needlegrass, western wheatgrass, needleandthread, porcupinegrass, little bluestem, and big bluestem are the major species

Blue grama, western wheatgrass, threadleaf sedge, sideoats grama, little bluestem, prairie sandreed, switchgrass, sand bluestem, and needleandthread are the major species

Little bluestem, prairie sandreed, green needlegrass, and needleandthread are dominant species / Sideoats grama and plains muhly are important on shallow soils.

big and little bluestem, porcupinegrass and green needlegrass / Needleandthread and prairie dropseed are important species on the steeper soils

big and little bluestem, indiangrass, porcupinegrass, and green needlegrass. Needleandthread and prairie dropseed are important species on the steeper soils 
Appendix II. List of locations, sample numbers, laboratories, and contributing scientists for samples used in the first general carbon equation.

\begin{tabular}{lcll}
\hline \multicolumn{1}{c}{ Location } & No. Samples & \multicolumn{1}{c}{ Labs } & \multicolumn{1}{c}{ Scientist } \\
\hline Akron, CO & 12 & USDA, Lincoln NE & Brian Wienhold \\
Argentina & 14 & Texas A\&M Univ. & Wylie Harris \\
Blackland Prairies, TX & 24 & Texas A\&M Univ. & R. Blaisdell \\
Brookings, SD & 11 & USDA, Lincoln NE & Brian Wienhold \\
Bushland, TX & 22 & USDA, Lincoln NE & Brian Wienhold \\
Fargo, ND & 13 & USDA, Lincoln NE & Brian Wienhold \\
Las Cruces, NM & 24 & USDA, Las Cruces, NM & Jeff Herrick \\
Mandan, ND & 17 & USDA, Lincoln NE & Brian Wienhold \\
Mead, NE & 32 & USDA, Lincoln NE & Brian Wienhold \\
Nebraska & 138 & Univ. Nebraska Lincoln & Achim Doberman \\
Ohio & 37 & Ohio State Univ. & Warren Dick \\
Sidney, MT & 3 & USDA, Lincoln NE & Brian Wienhold \\
Swift Current, Canada & 21 & USDA, Lincoln NE & Brian Wienhold \\
Throckmorton, TX & 104 & Univ. Nebraska & R. Blaisdell \\
Throckmorton, TX & 64 & Colorado State Univ. & Richard Teague and \\
& & & Cindy Cambardella \\
Vernon, TX & 59 & Colorado State Univ. & Richard Teague and \\
& & & Cindy Cambardella \\
Wyoming & 66 & Univ. of Wyoming & Jerry Schuman \\
& & & \\
Total & 661 & & 7 \\
\hline
\end{tabular}


Appendix III. Soils database - listing collection locations, labs, constituents of interest and collaborators.

\begin{tabular}{|c|c|c|c|c|}
\hline Location & n & Lab & $\begin{array}{l}\text { Constituents of } \\
\text { Interest }\end{array}$ & Collaborators \\
\hline $\begin{array}{l}\text { Big Brown Mine } \\
\text { Fairfield, Texas }\end{array}$ & 170 & $\begin{array}{l}\text { Univ. Delaware } \\
\text { (FAME) }\end{array}$ & FAME & $\begin{array}{l}\text { Allen Peach } \\
\text { David Zuberer }\end{array}$ \\
\hline $\begin{array}{l}\text { Blackland Prairie, } \\
\text { Central } \\
\text { Texas }\end{array}$ & 269 & $\begin{array}{l}\text { Texas A\&M Univ. } \\
\text { Univ. Delaware }\end{array}$ & $\begin{array}{l}\text { OC,TN, IN, FAME } \\
(\mathrm{n}=40)\end{array}$ & $\begin{array}{l}\text { Robert Blaisdell } \\
\text { Steve Whisenant } \\
\text { David Zuberer }\end{array}$ \\
\hline Utah & 26 & USDA Lincoln, NE & Glomalin & Jayne Belnap \\
\hline Ohio & 200 & Univ. Ohio & OC, enzymes & Warren Dick \\
\hline Nebraska & 147 & Univ. Nebraska & $\mathrm{OC}, \mathrm{TN}$ & Achim Doberman \\
\hline Oklahoma & 261 & Oklahoma State Univ. & $\mathrm{NO} 3, \mathrm{P}, \mathrm{K}$ OC & Sam Fuhlendorf \\
\hline Argentina & 16 & Texas A\&M Univ. & OC, TN, C13, N15 & Wylie Harris \\
\hline $\begin{array}{l}\text { Las Cruces } \\
\text { New Mexico }\end{array}$ & 36 & $\begin{array}{l}\text { USDA Beltsville } \\
\text { USDA Las Cruces }\end{array}$ & $\begin{array}{l}\text { Glomalin } \\
\text { OC, TN }\end{array}$ & Jeff Herrick \\
\hline Kansas - Colorado & 33 & Colorado State Univ. & OC, TN, FAME & Rebecca McCulley \\
\hline Wyoming & 108 & Univ. Wyoming & $\mathrm{OC}, \mathrm{TN}$ & Jerry Schuman \\
\hline Vernon, Texas & 71 & Colorado State Univ. & $\mathrm{OC}, \mathrm{IC}, \mathrm{TN}, \mathrm{POM}$ & $\begin{array}{l}\text { Richard Teague } \\
\text { Cindy Cambardella }\end{array}$ \\
\hline Bushland, Texas & 24 & USDA Lincoln, NE & $\begin{array}{l}\text { OC (whole soil) } \\
\text { glomalin (particle } \\
\text { size) }\end{array}$ & Brian Wienhold \\
\hline Fargo, North Dakota & 24 & USDA Lincoln, NE & $\begin{array}{l}\text { OC (whole soil) } \\
\text { glomalin (particle size }\end{array}$ & Brian Wienhold \\
\hline Mead, Kansas & 44 & USDA Lincoln, NE & $\begin{array}{l}\text { OC (whole soil) } \\
\text { glomalin (particle size }\end{array}$ & Brian Wienhold \\
\hline Swift Current, Canada & 36 & USDA Lincoln, NE & $\begin{array}{l}\text { OC (whole soil) } \\
\text { glomalin (particle } \\
\text { size) }\end{array}$ & Brian Wienhold \\
\hline Bushland, Texas & 17 & USDA Lincoln, NE & OC,TN, POM & Brian Wienhold \\
\hline Fargo, North Dakota & 20 & USDA Lincoln, NE & OC,TN, POM & Brian Wienhold \\
\hline Mandan, North Dakota & 25 & USDA Lincoln, NE & OC,TN, POM & Brian Wienhold \\
\hline Mead, Nebraska & 28 & USDA Lincoln, NE & OC,TN, POM & Brian Wienhold \\
\hline Sidney, Montana & 22 & USDA Lincoln, NE & OC,TN, POM & Brian Wienhold \\
\hline Swift Current, Canada & 18 & USDA Lincoln, NE & OC,TN, POM & Brian Wienhold \\
\hline Akron, Colorado & 12 & USDA Lincoln, NE & OC,TN, POM & Brian Wienhold \\
\hline $\begin{array}{l}\text { Brookings, South } \\
\text { Dakota }\end{array}$ & 18 & USDA Lincoln, NE & OC,TN, POM & Brian Wienhold \\
\hline Throckmorton, TX & 460 & $\begin{array}{l}\text { Univ. Nebraska (n } \\
=132) 328 \text { predicted by } \\
\text { NIRS }\end{array}$ & $\mathrm{OC}, \mathrm{IC}, \mathrm{TN}$ & $\begin{array}{l}\text { Robert Blaisdell } \\
\text { Jerry Stuth }\end{array}$ \\
\hline $\begin{array}{l}\text { Manhattan, Kansas } \\
\text { Konza }\end{array}$ & $\sim 390$ & Kansas State Univ. & OC, TN & $\begin{array}{l}\text { Chuck Rice } \\
\text { Mickey Ransom } \\
\text { Kevin Price } \\
\text { Matt Ramspott }\end{array}$ \\
\hline sum & 2085 & 10 & & 18 \\
\hline
\end{tabular}




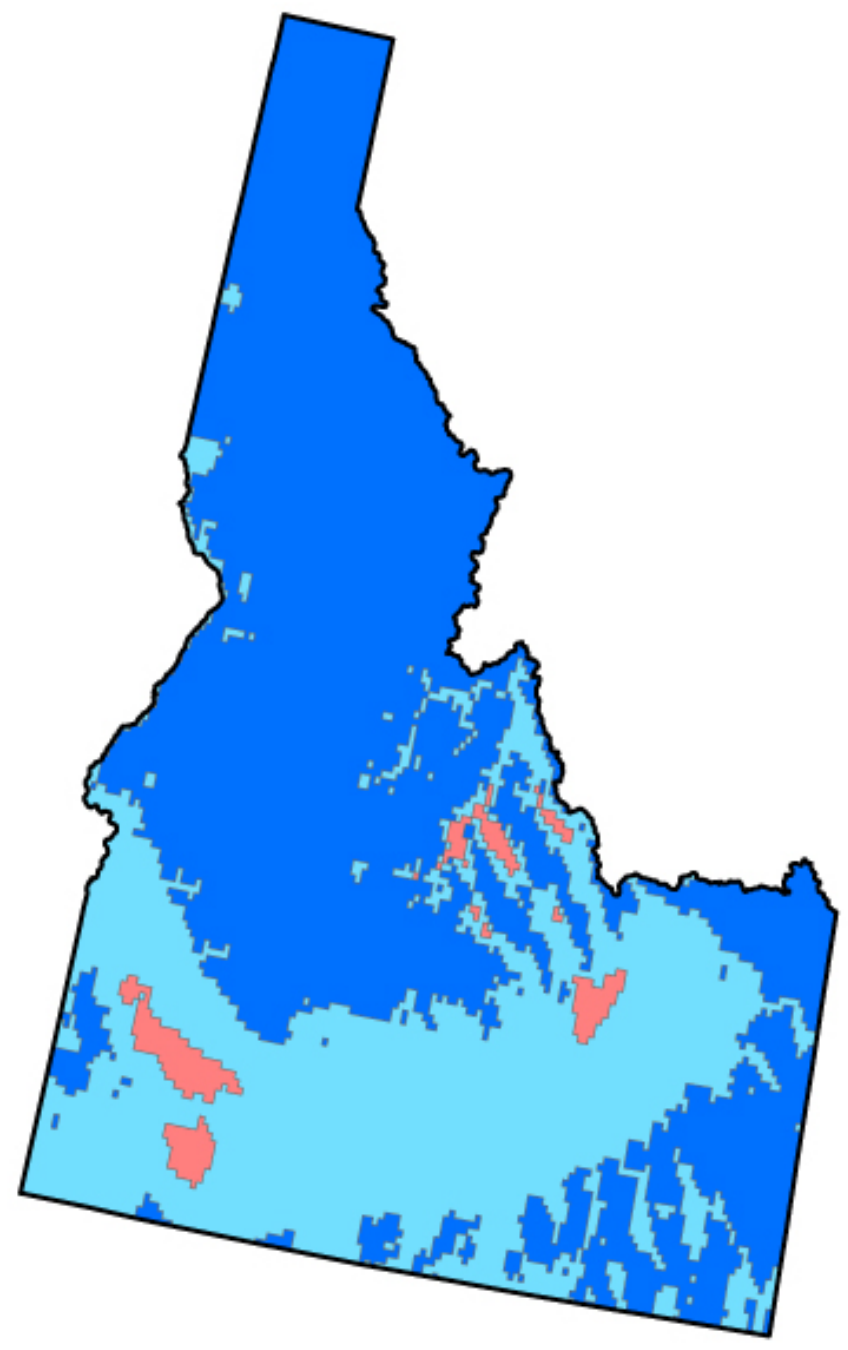

\section{Rainfall Potential}

High Potential

Moderate Potential

Low Potential

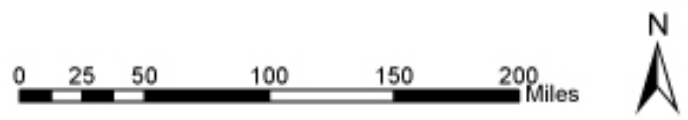

Figure 1. Spatial classification of climatic potential for Idaho. Areas classified as High Potential have greater than $460 \mathrm{~mm}$ of precipitation per year. Areas classified as Moderate Potential have between 230 and $460 \mathrm{~mm}$ of precipitation per year. Areas classified as Low Potential have between 130 and $230 \mathrm{~mm}$ of precipitation per year. 


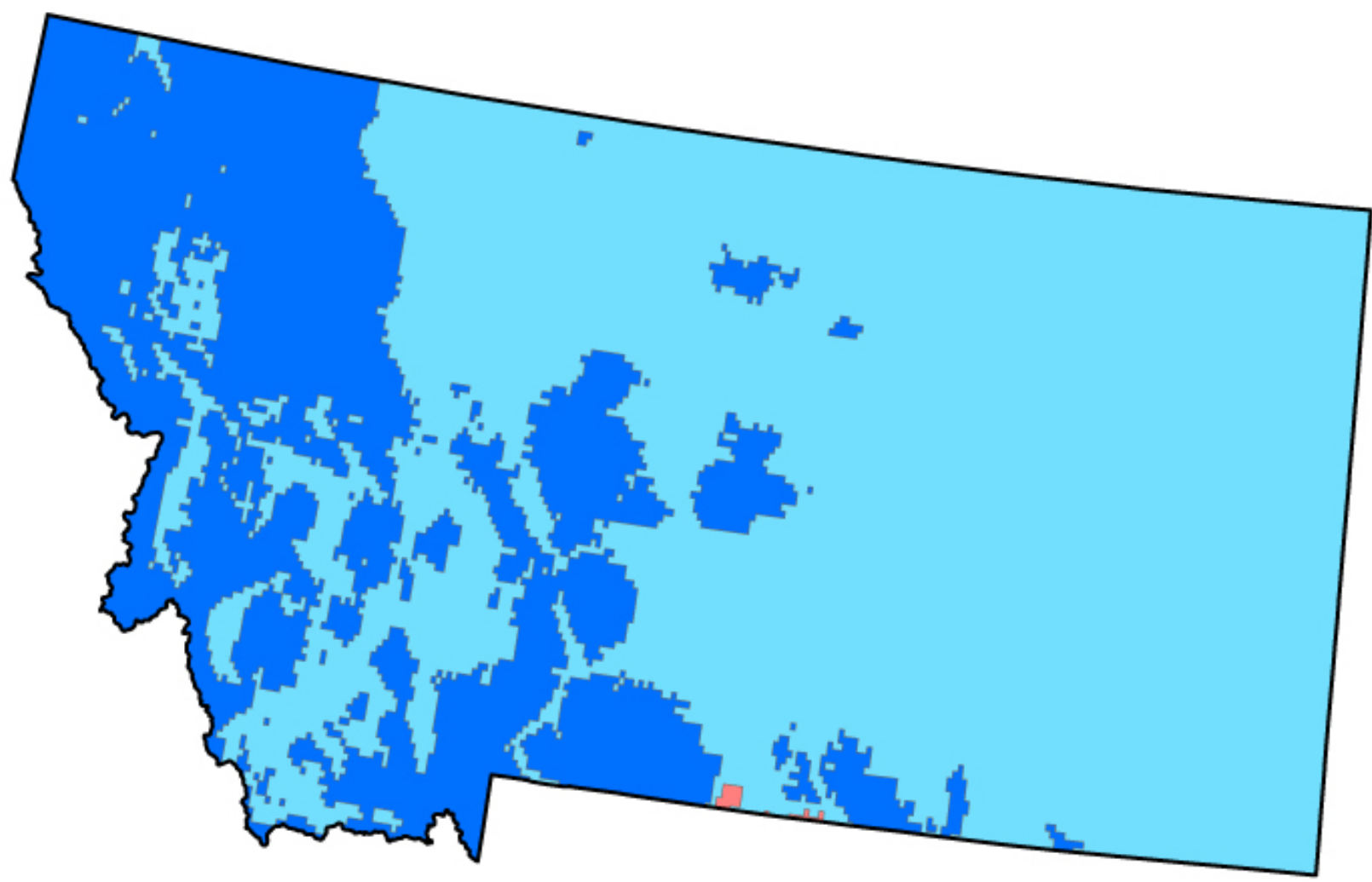

\section{Rainfall Potential}

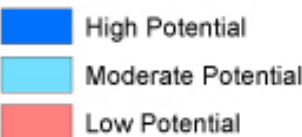

Low Potential

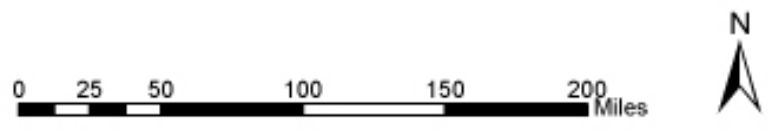

Figure 2. Spatial classification of climatic potential for Montana. Areas classified as High Potential have greater than $460 \mathrm{~mm}$ of precipitation per year. Areas classified as Moderate Potential have between 230 and $460 \mathrm{~mm}$ of precipitation per year. Areas classified as Low Potential have between 130 and $230 \mathrm{~mm}$ of precipitation per year. 


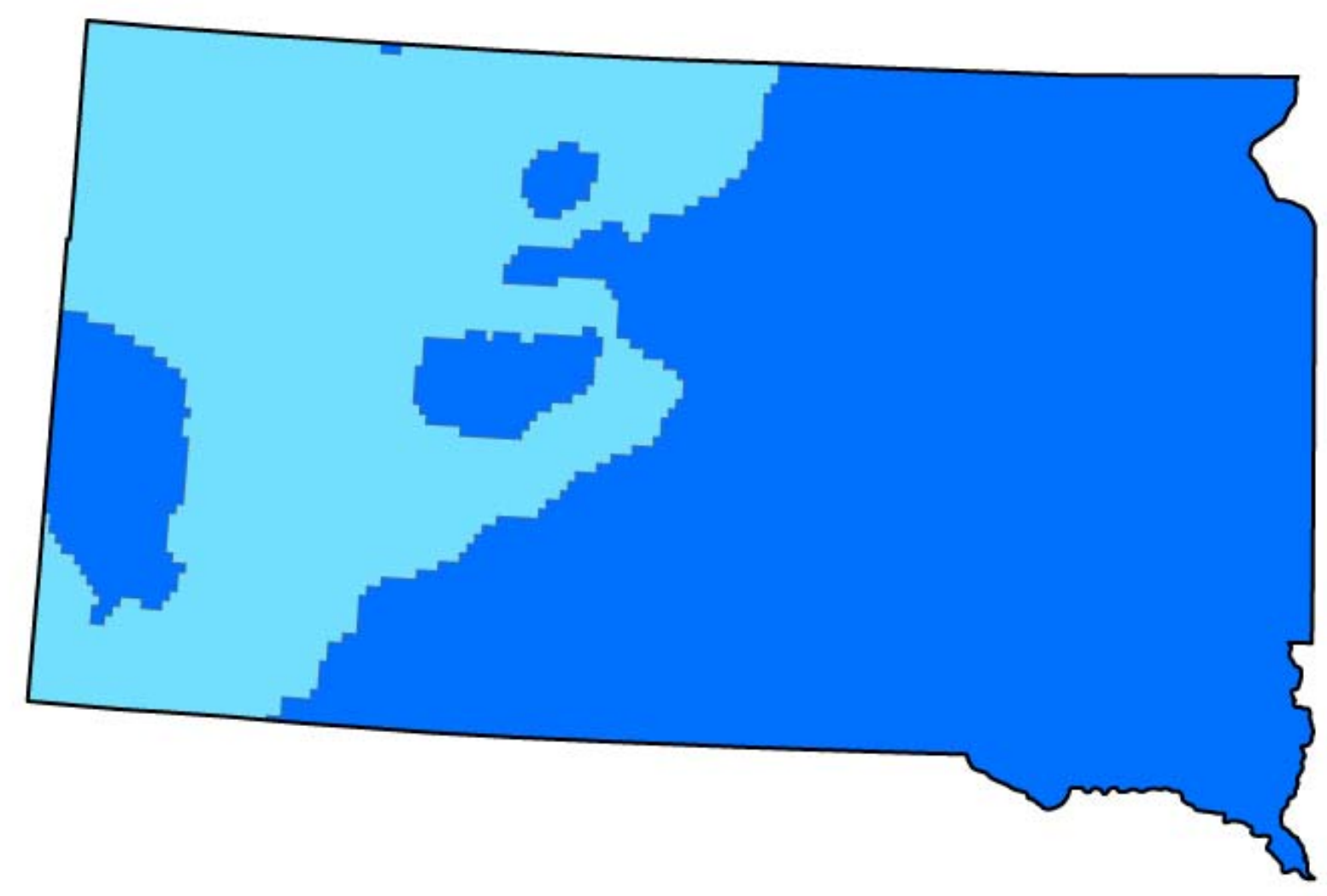

\section{Rainfall Potential}

High Potential

Moderate Potentis

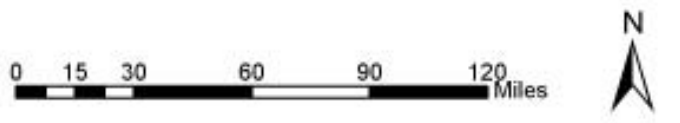

Figure 3. Spatial classification of climatic potential for South Dakota. Areas classified as High Potential have greater than $460 \mathrm{~mm}$ of precipitation per year. Areas classified as Moderate Potential have between 230 and $460 \mathrm{~mm}$ of precipitation per year. 


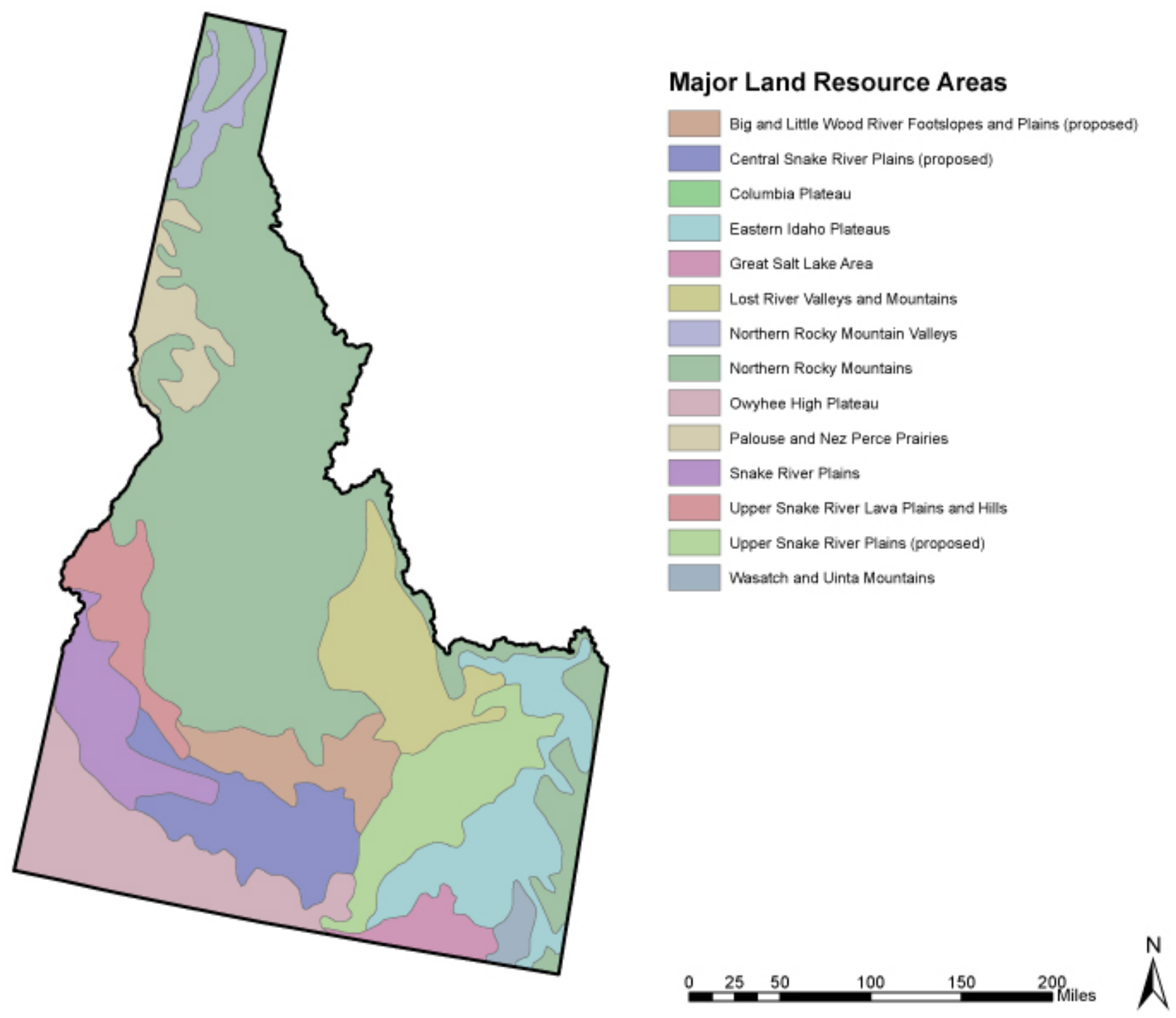

Figure 4. Major land resource areas (MLRAs) within the state of Idaho. 


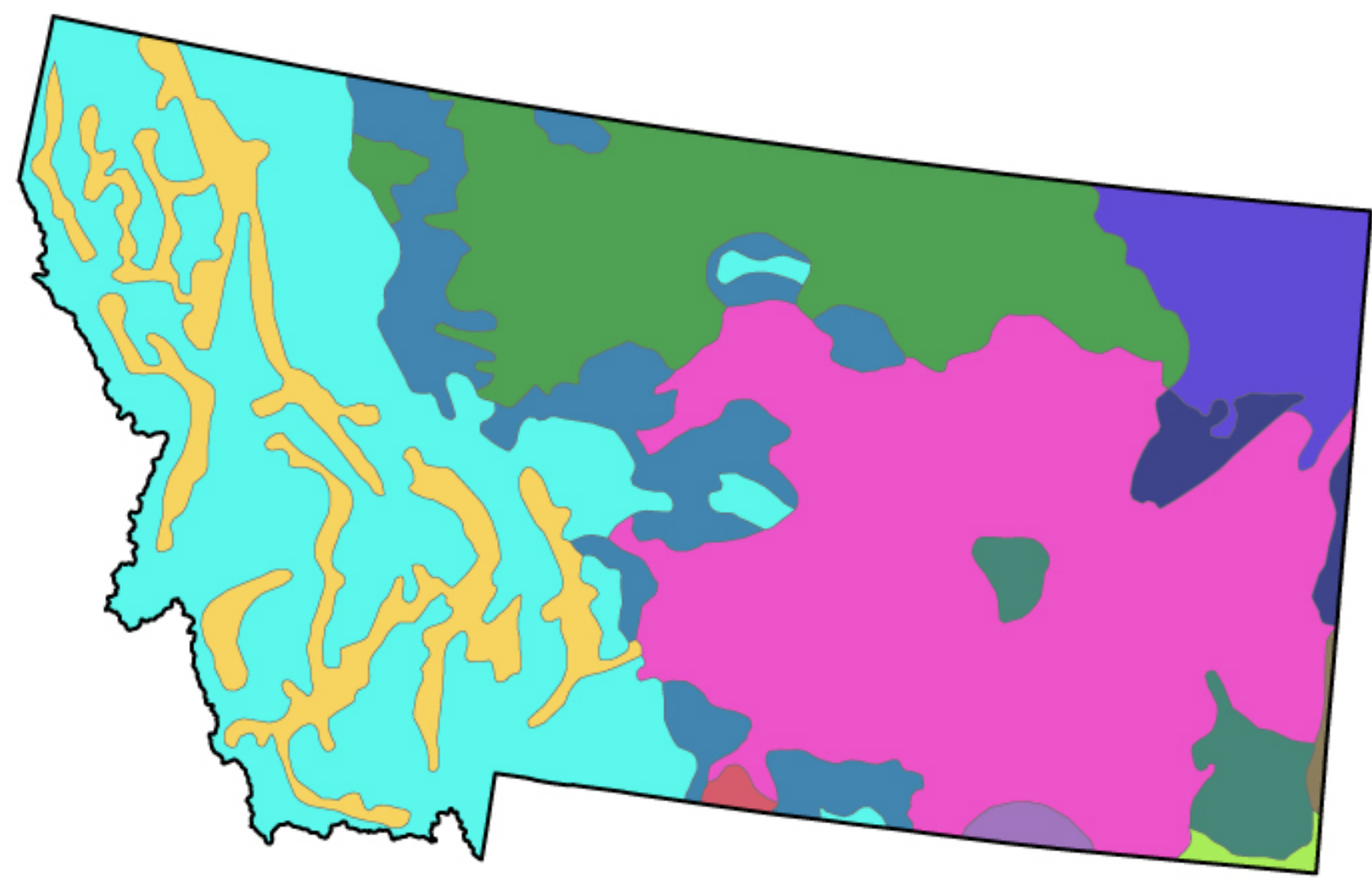

\section{Major Land Resource Areas}
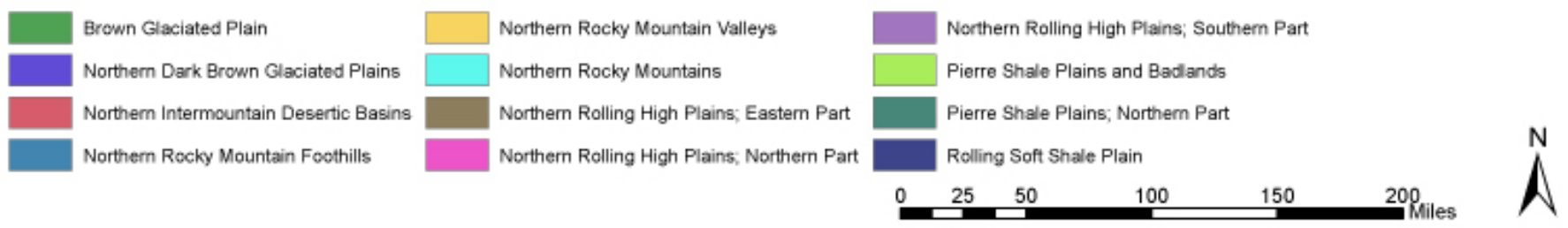

Figure 5. Major land resource areas (MLRAs) within the state of Montana. 


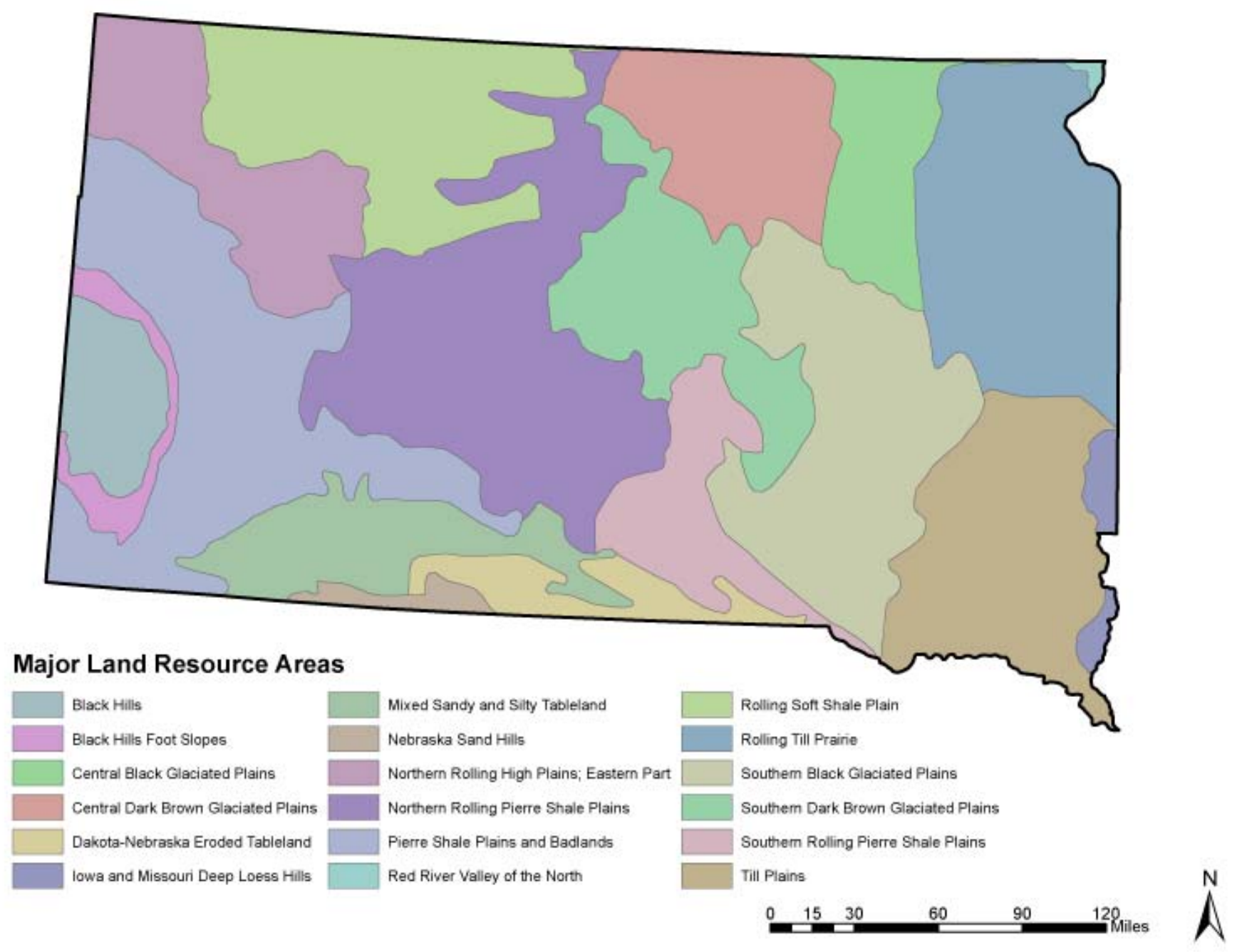

Figure 6. Major land resource areas (MLRAs) within the state of South Dakota 


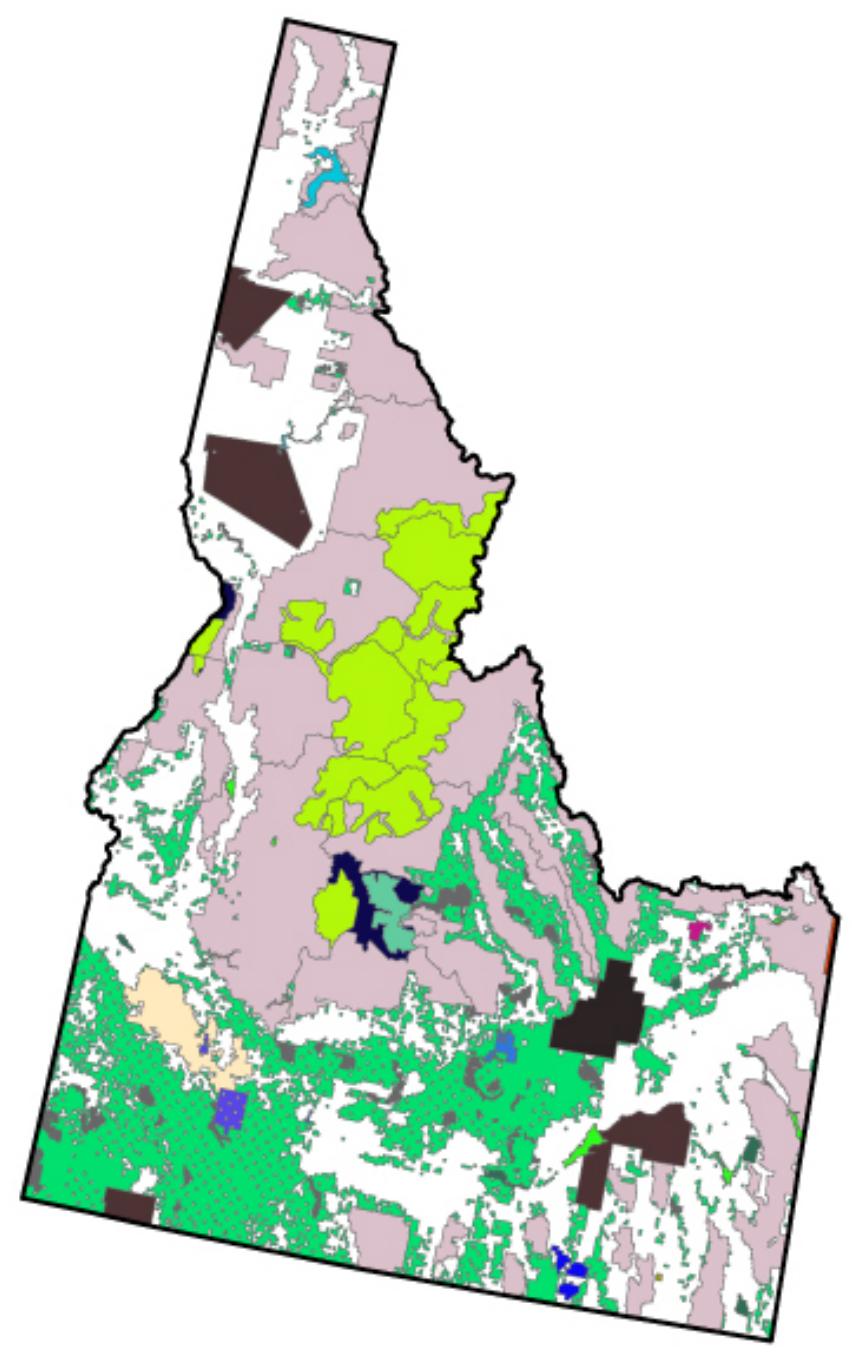

\section{Federal Lands and Indian Reservations}

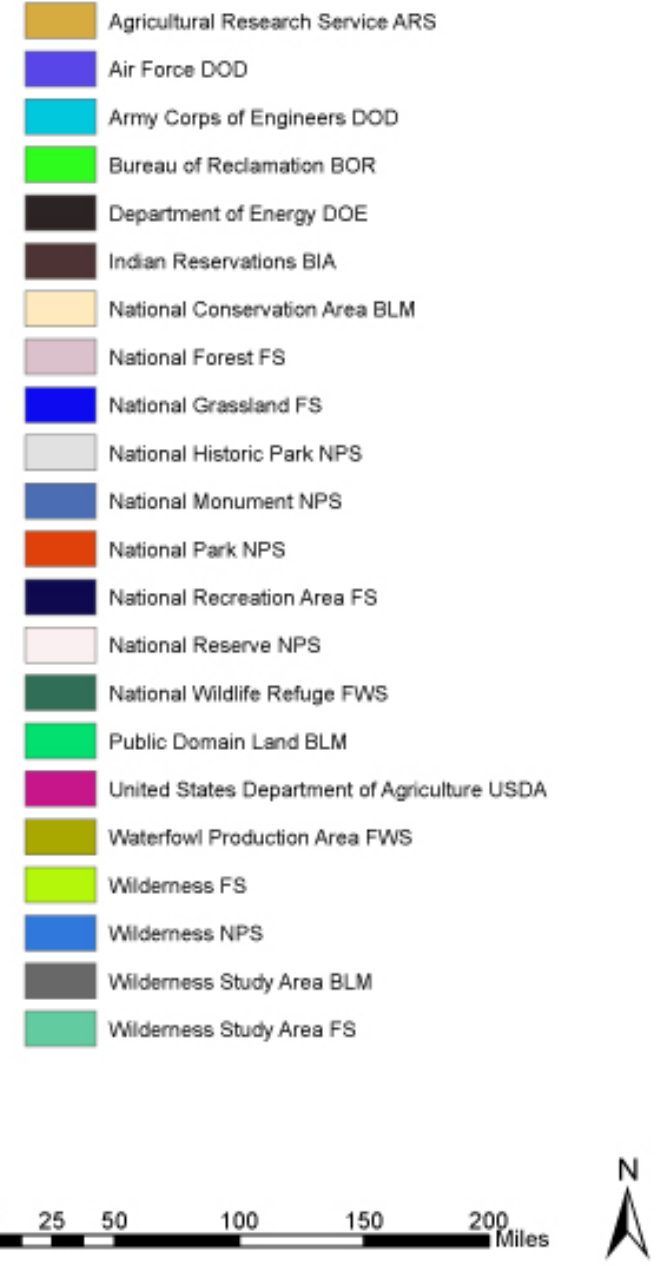

Figure 7. Federal lands and Indian reservations within the state of Idaho. 


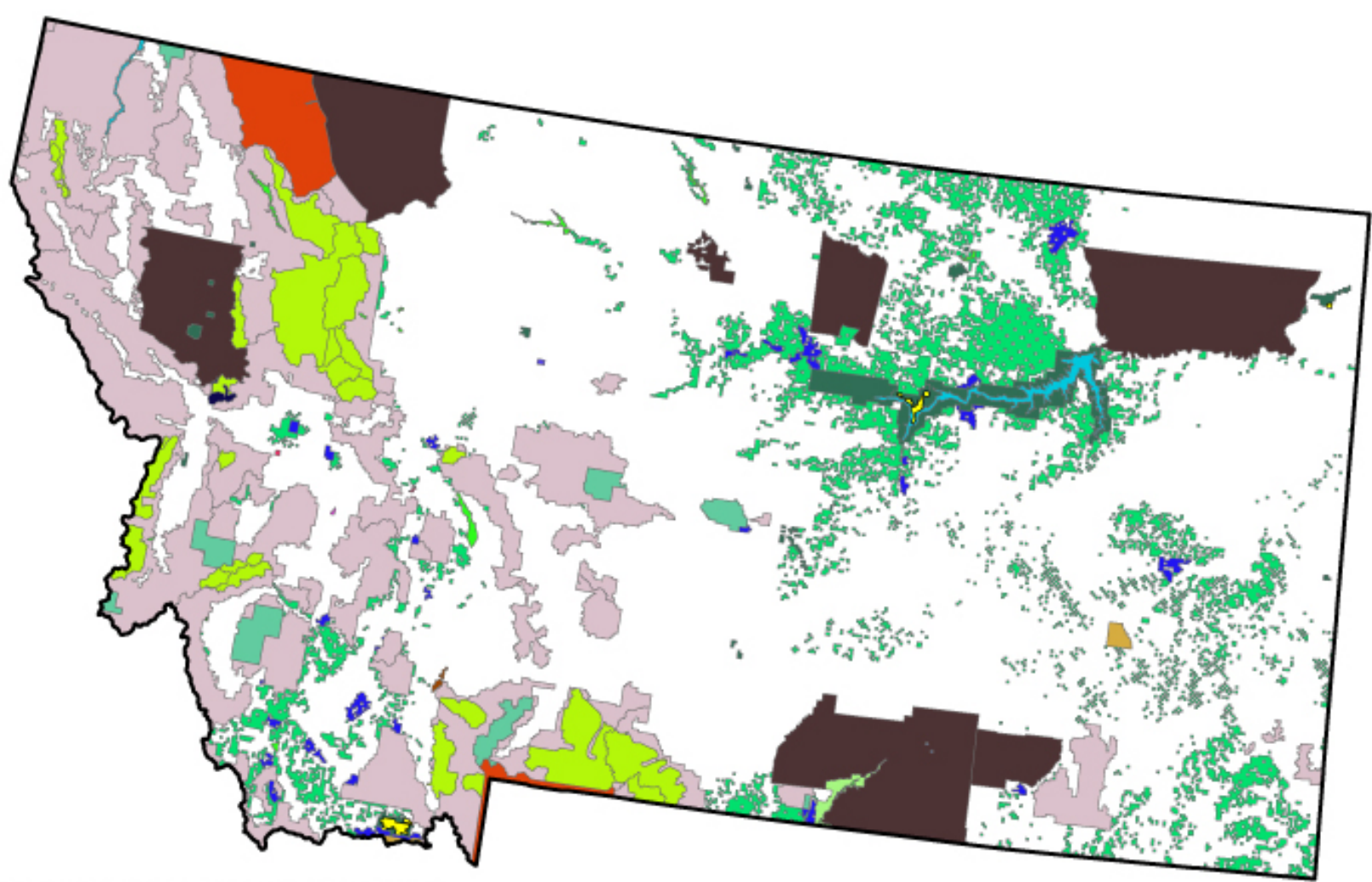

Federal Land and Indian Reservations

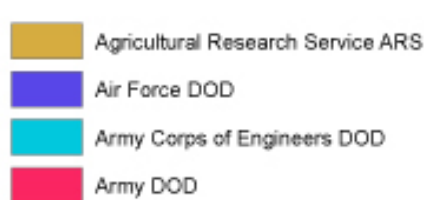

Army DOD

Bureau of Reclamation BOR
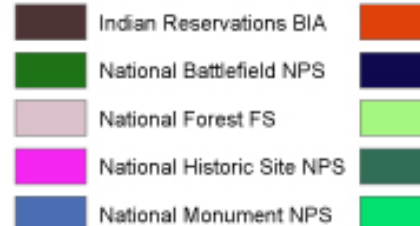

Wilderness BLM Wilderness FS

Wilderness FWS

Wilderness Study Area BLM Wilderness Study Area FS

Public Domain Land BLM

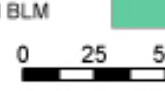

Figure 8. Federal lands and Indian reservations within the state of Montana. 


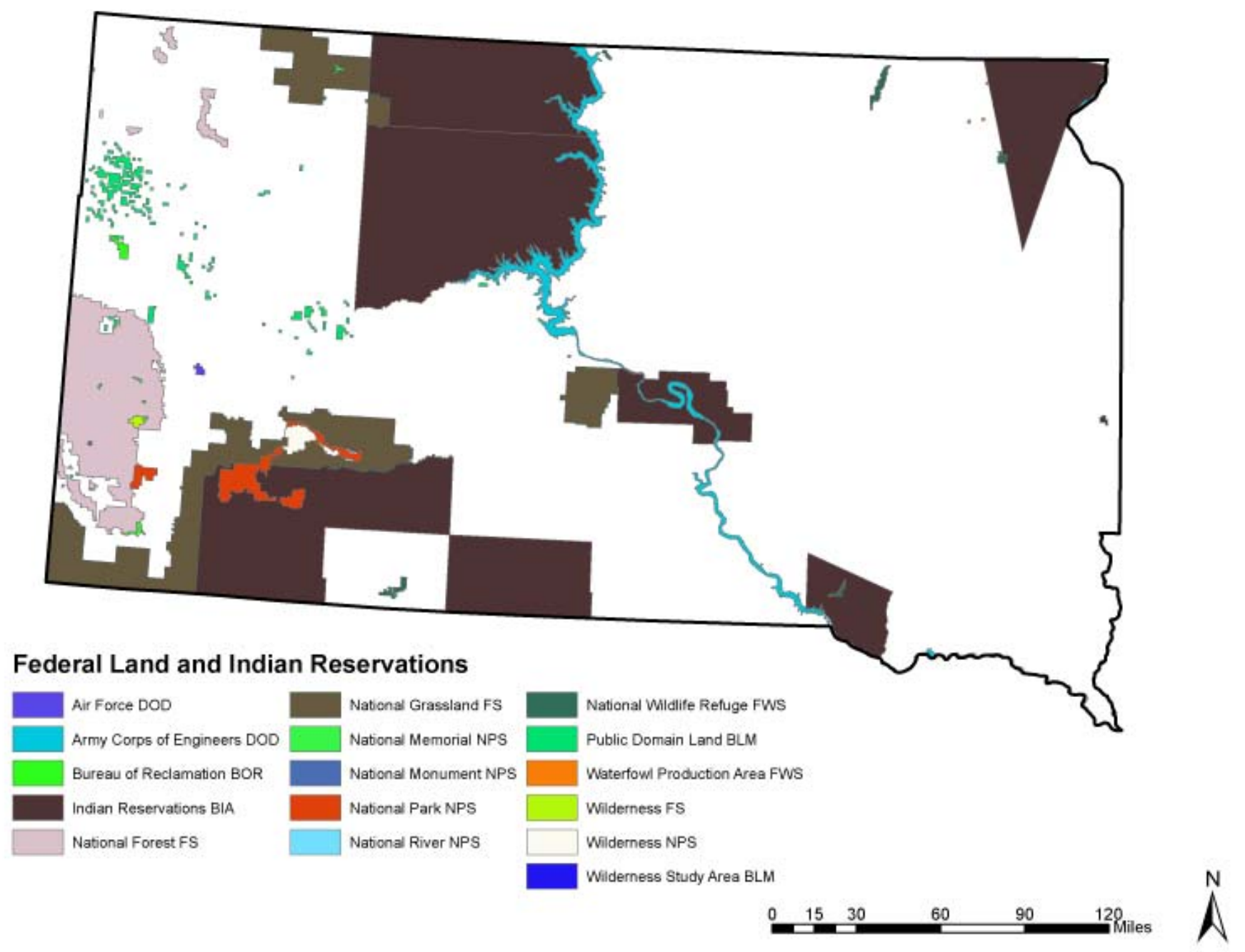

Figure 9. Federal lands and Indian reservations within the state of South Dakota 


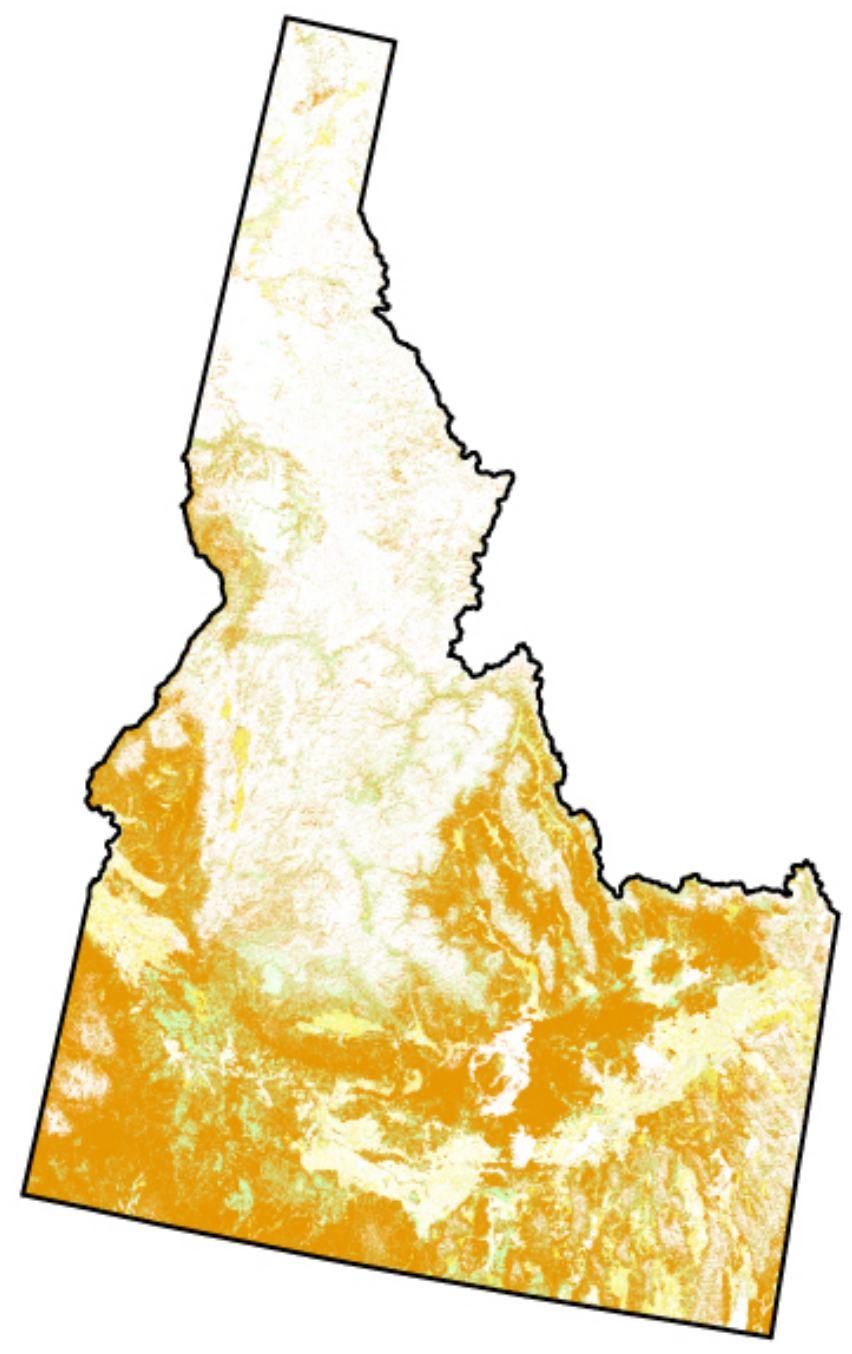

\section{Rangeland Cover Types}

Shrubland

Grassland/Herbaceous

Pasture/Hay

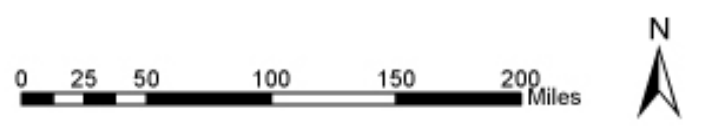

Figure10. Rangeland cover types for the state of Idaho as classified by the National Land Cover Database. 


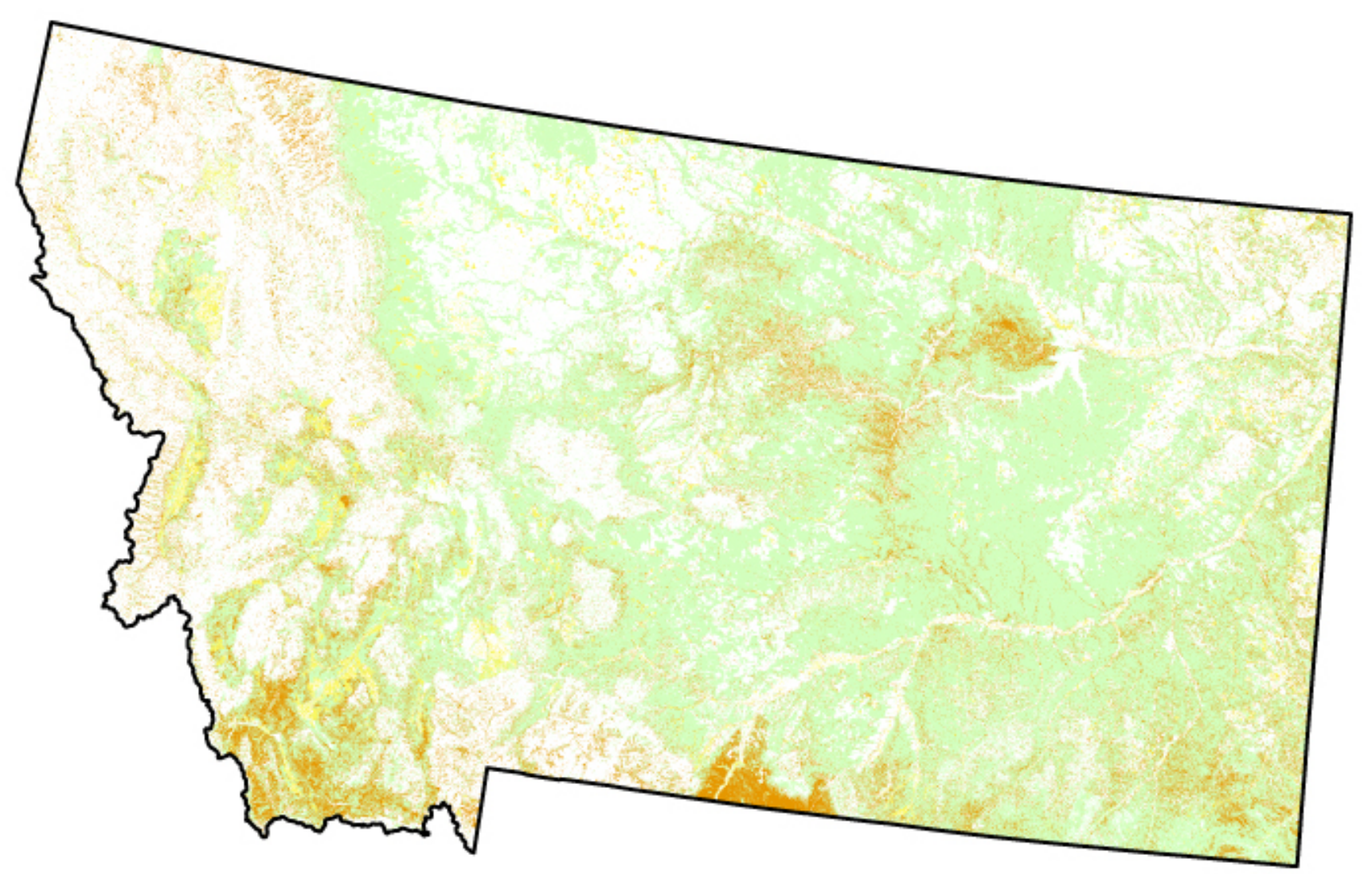

\section{Rangeland Cover Types}
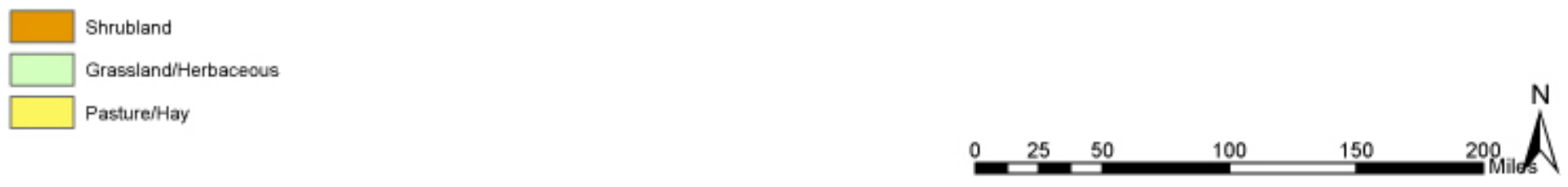

Figure 11. Rangeland cover types for the state of Montana as classified by the National Land Cover Database. 


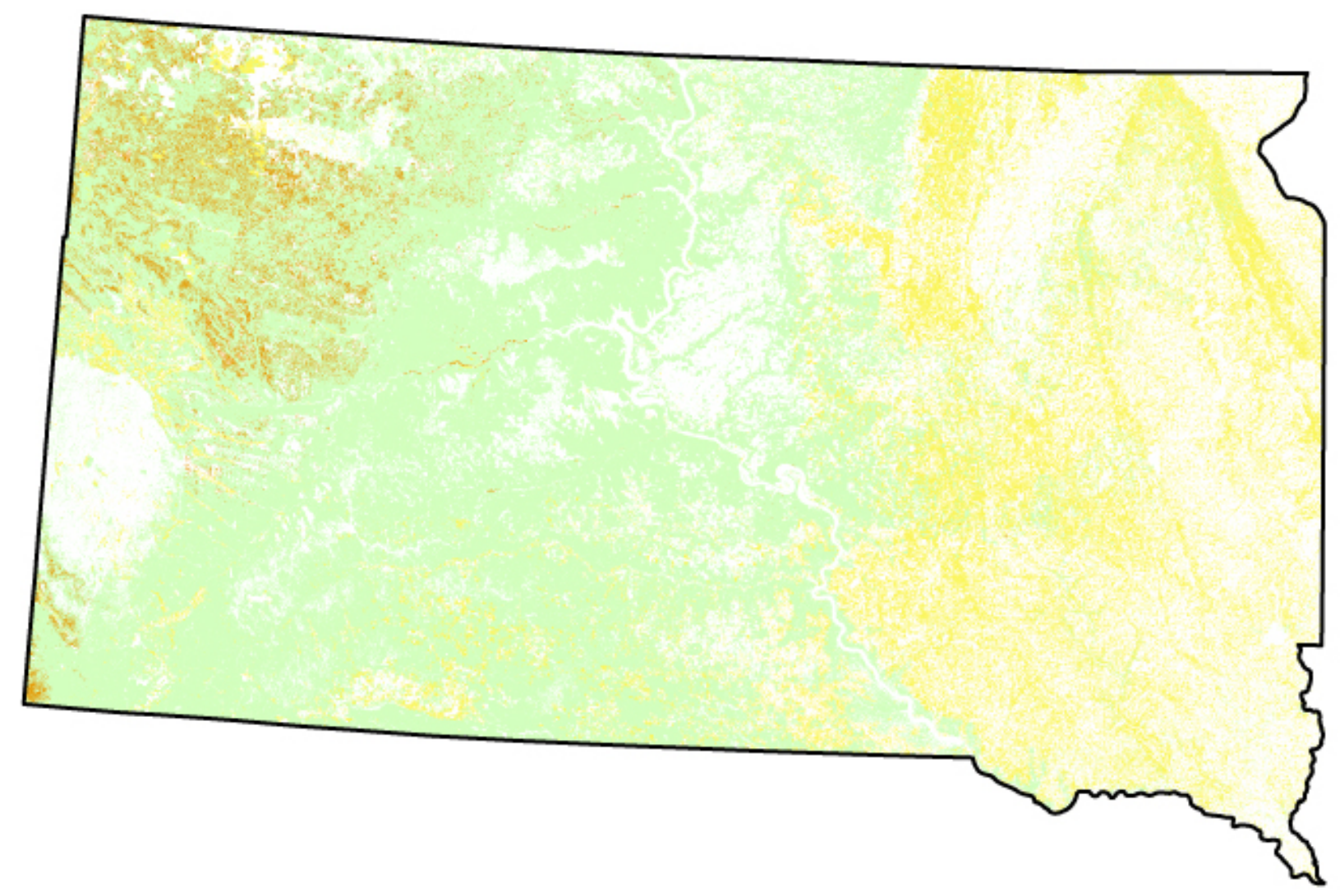

\section{Rangeland Land Cover Types}
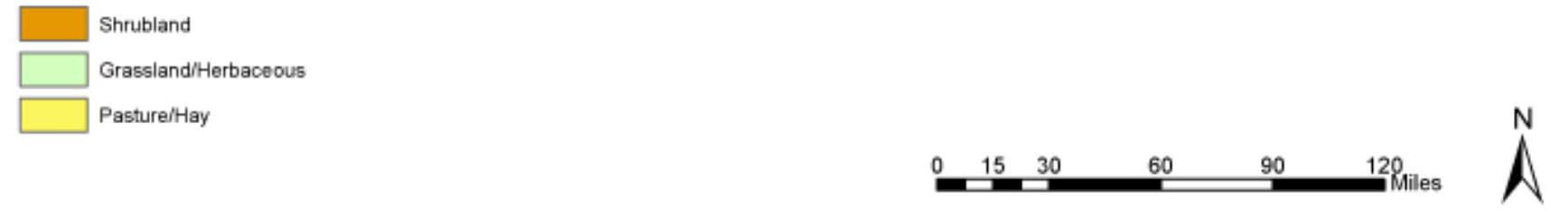

Figure 12. Rangeland cover types for the state of South Dakota as classified by the National Land Cover Database. 


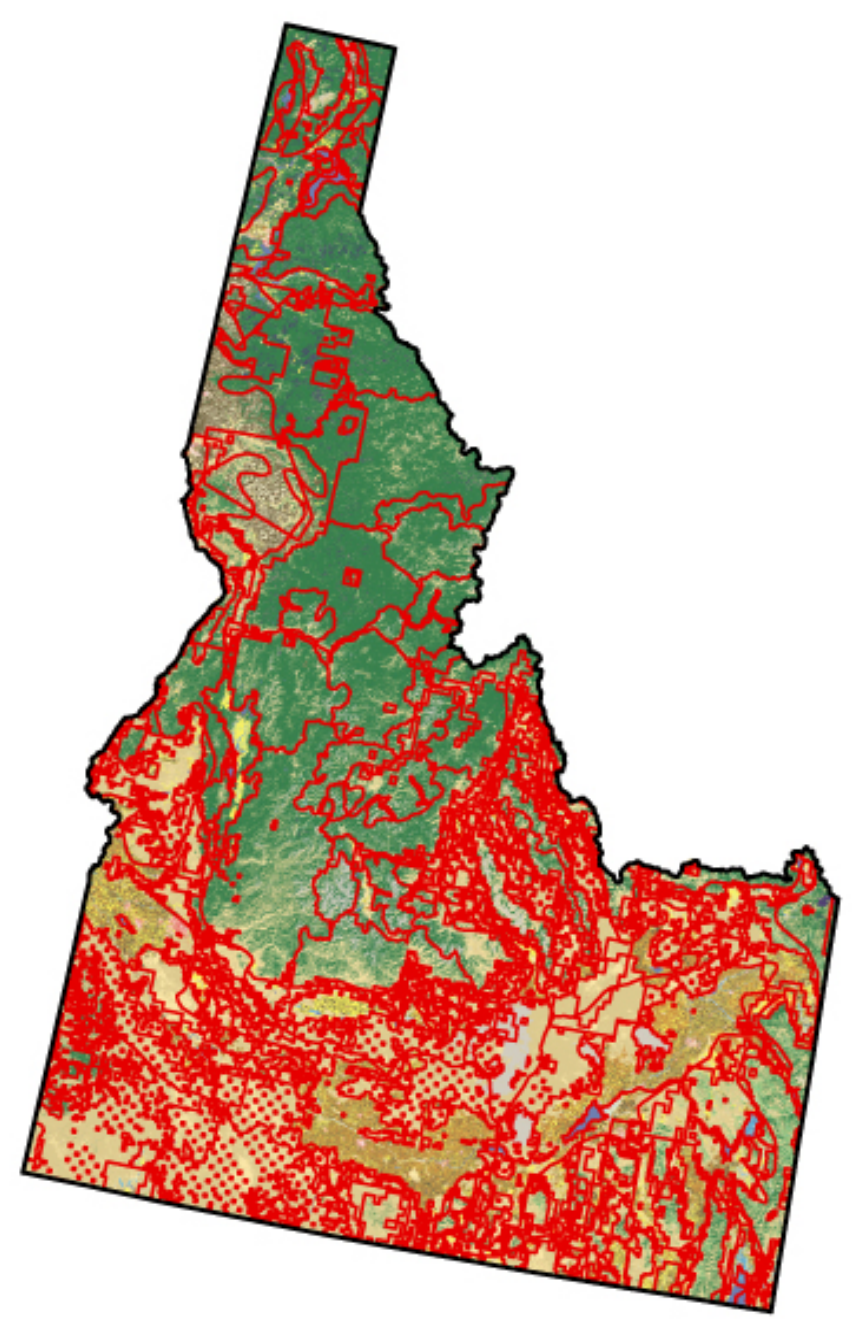

\section{National Land Cover}

$\square$ MLRA+Rain+Fed Lands Open Water

Perennial lce Snow

Low Intensity Residential

High Intensity Residentis

Commercial/Industrial/Transportation

Bare Rock/Sand/Clay

Quarries/Strip Mines/Gravel Pits

Transitional

Deciduous Forest

Evergreen Forest

Mixed Forest

Shrubland

Orchards/Vineyards/Other

Grassland/Herbaceous

Pasture/Hay

Row Crops

Small Grains

Fallow

Urban/Recreational Areas

Woody Wetlands

Emergent Herbaceous Wetlands

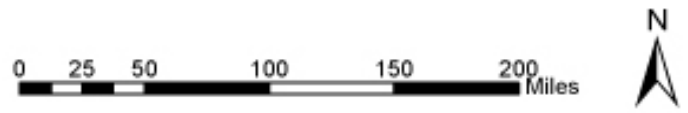

Figure 13. Sampling units (red lines) used in the spatial cross tabulation for the state of Idaho. The sampling units represent the intersection of the Major Land Resource Areas, climatic potential, and Federal Lands and Indian Reservations map coverage that were used in the spatial cross-tabulation analysis of the National Land Cover Database to determine area coverage of rangeland land cover classes (shrublands, grassland/herbaceous, and pasture/hay). 


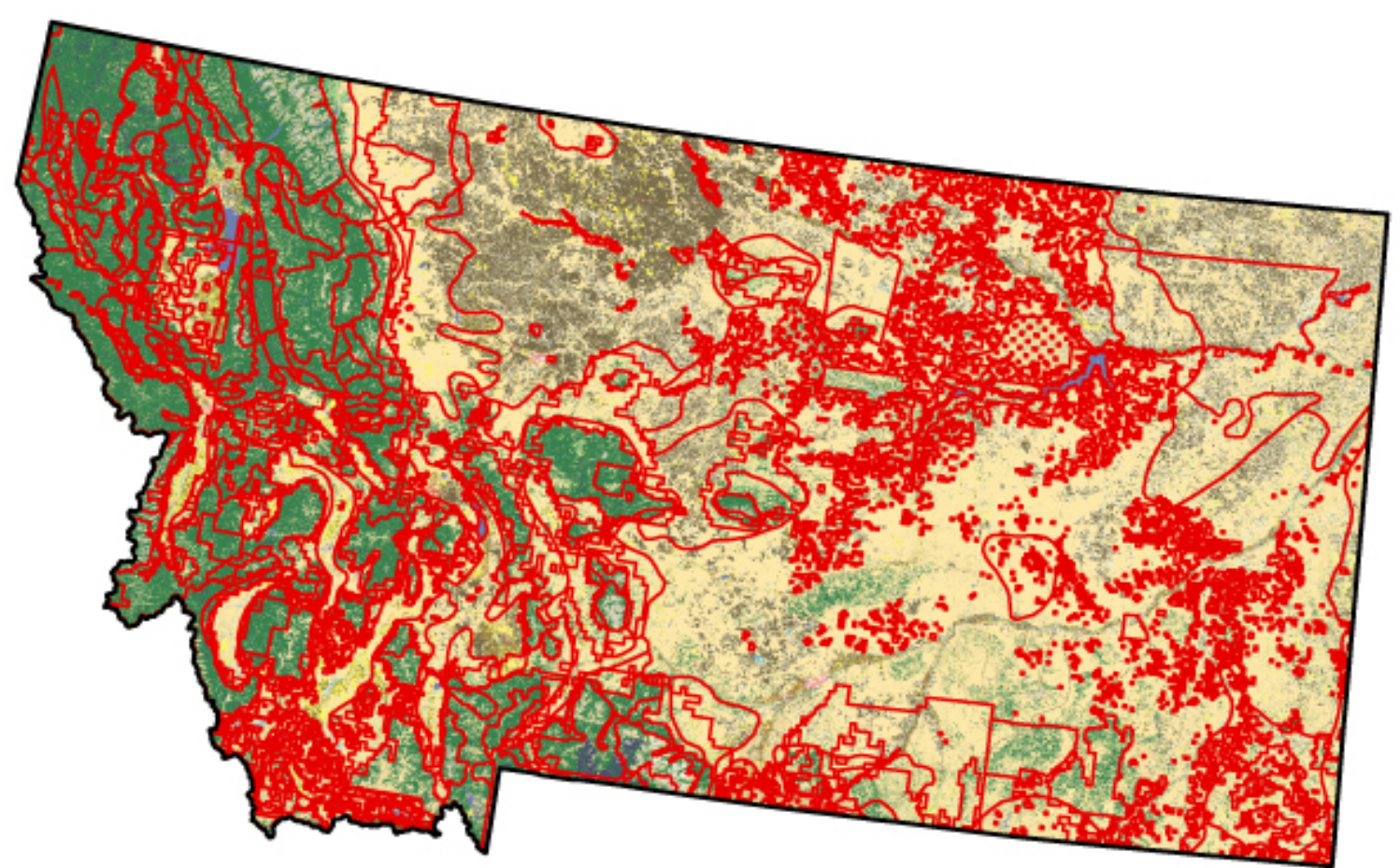

\section{National Land Cover}
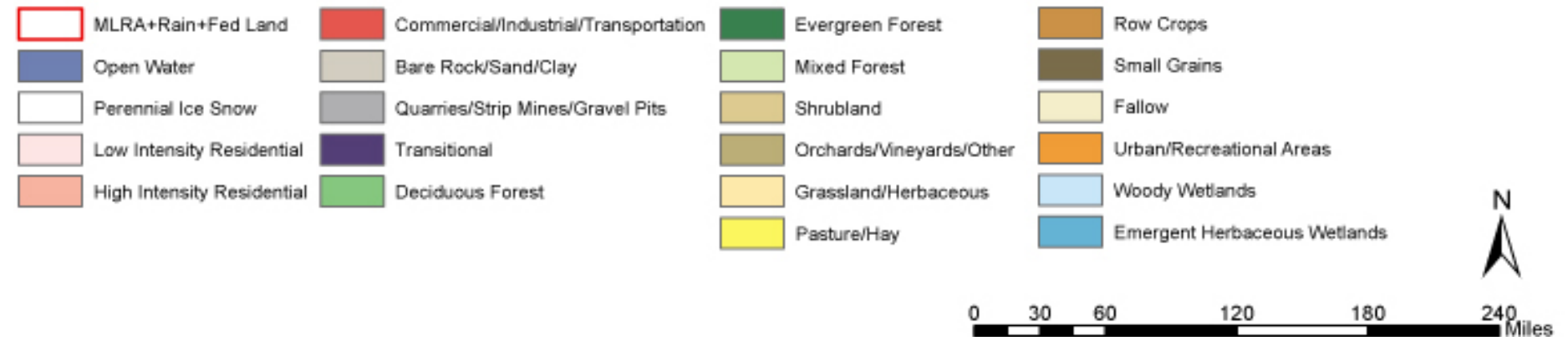

Figure 14. Sampling units (red lines) used in the spatial cross tabulation for the state of Montana. The sampling units represent the intersection of the Major Land Resource Areas, climatic potential, and Federal Lands and Indian Reservations map coverage that were used in the spatial cross-tabulation analysis of the National Land Cover Database to determine area coverage of rangeland land cover classes (shrublands, grassland/herbaceous, and pasture/hay). 


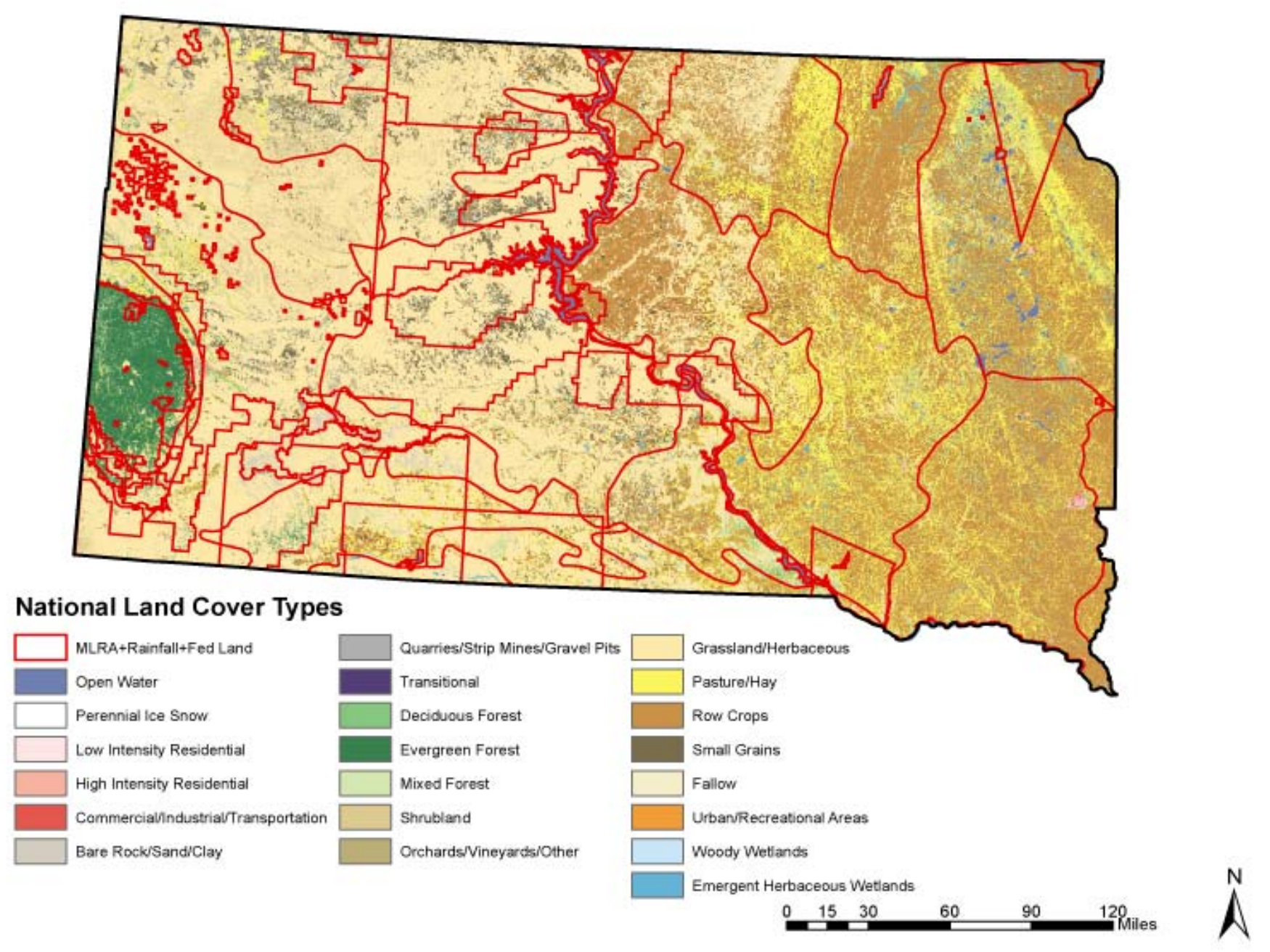

Figure 15. Sampling units (red lines) used in the spatial cross tabulation for the state of South Dakota. The sampling units represent the intersection of the Major Land Resource Areas, climatic potential, and Federal Lands and Indian Reservations map coverage that were used in the spatial cross-tabulation analysis of the National Land Cover Database to determine area coverage of rangeland land cover classes (shrublands, grassland/herbaceous, and pasture/hay). 


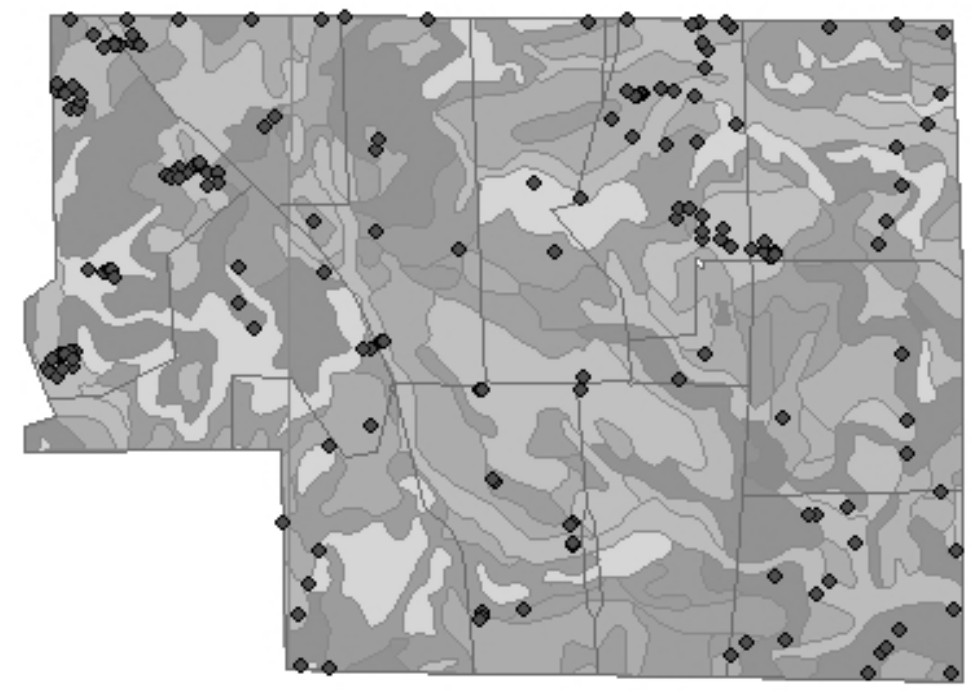

Figure 16. Distribution of sample points for Throckmorton Ranch placed over soil map and pasture boundaries. 


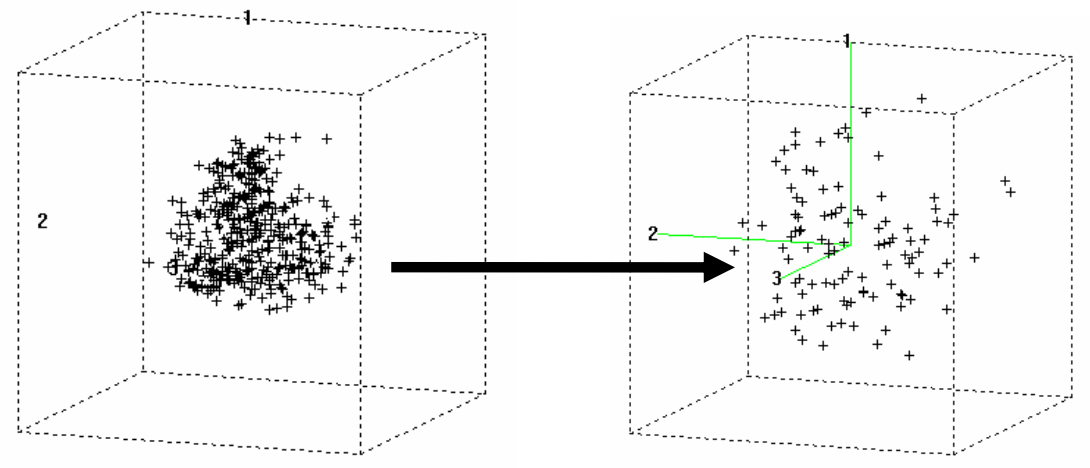

Figure 17. Selection of spectrally unique samples used to reduce laboratory costs and to choose samples that represent the range of population variance for equation development. From a total of 460 samples (left box) this procedure identified 107 spectrally unique samples (right box). 


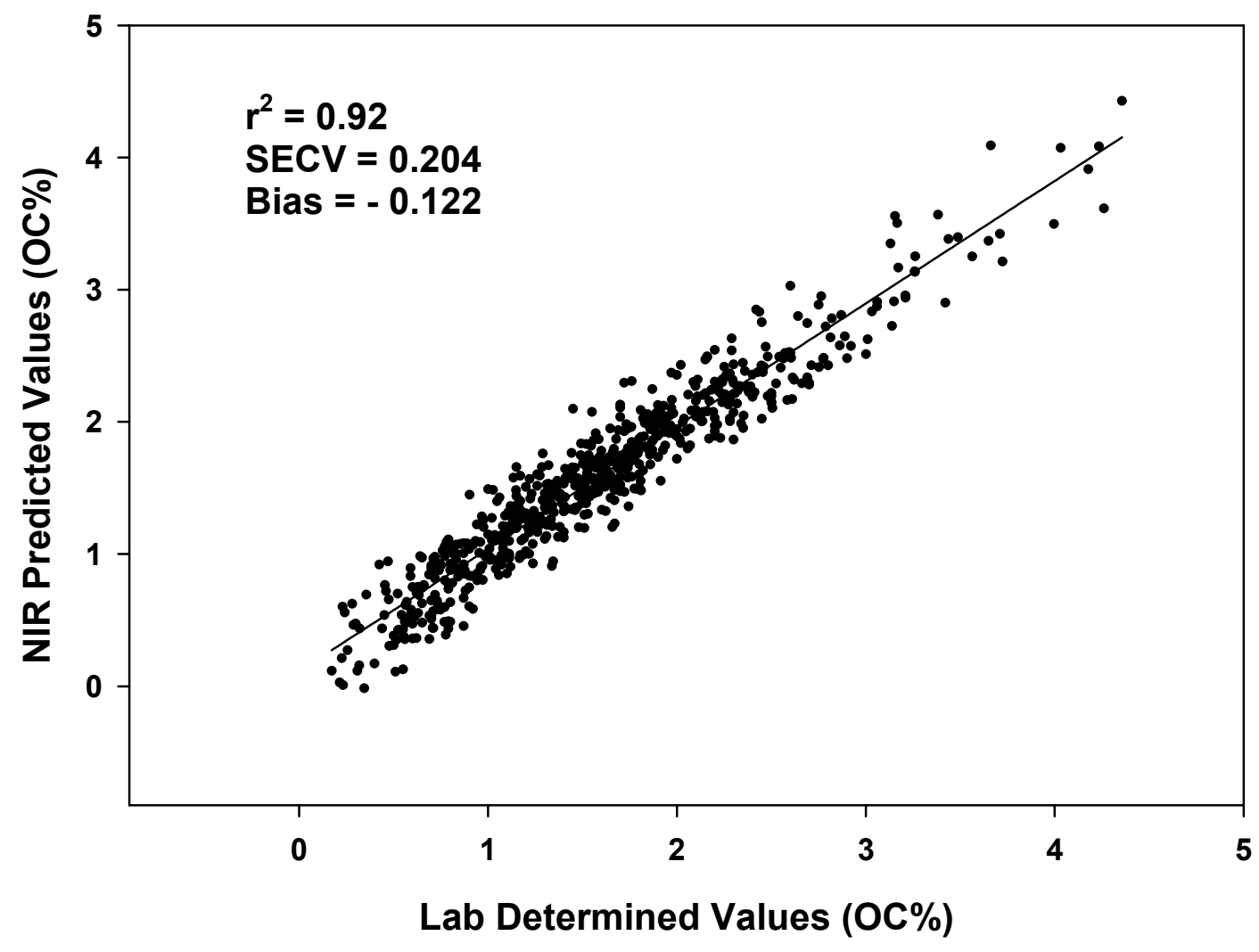

Figure 18. NIR cross validation prediction results for organic carbon using soils from diverse locations. $(n=661)$ 


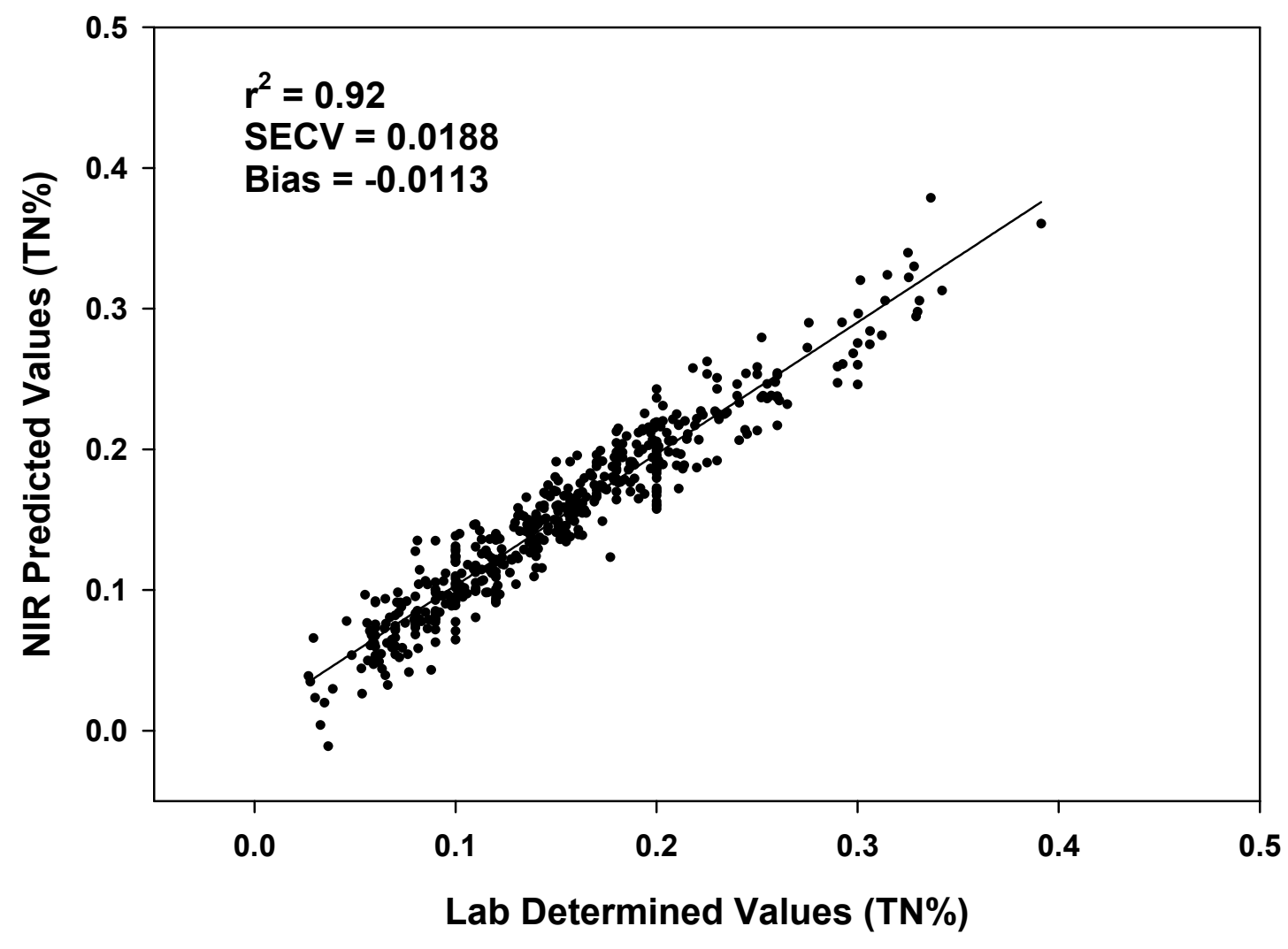

Figure 19. NIR cross validation prediction results for total nitrogen using soils from diverse locations $(n=502)$ 
Table 1. Rangeland (ha) by land cover class and sums of the classes for Major Land Resource Area (MLRA) and land tenure class grouped according to Climatic Potential for carbon sequestration in Idaho. Percent of total reflects the percent of total rangeland occupied by the MLRA and Land Tenure class within the climatic potential grouping.

\begin{tabular}{|c|c|c|c|c|c|c|}
\hline $\begin{array}{c}\text { NRCS Major Land } \\
\text { Resource Area }\end{array}$ & Land Tenure & Shrubland & $\begin{array}{l}\text { Grasslands/ } \\
\text { Herbaceous }\end{array}$ & $\begin{array}{c}\text { Pasture/ } \\
\text { Hay }\end{array}$ & $\begin{array}{c}\text { Rangeland } \\
\text { Totals } \\
\end{array}$ & $\begin{array}{l}\text { Percent } \\
\text { of Total }\end{array}$ \\
\hline \multicolumn{7}{|c|}{ High Climatic Potential $(>460 \mathrm{~mm})$} \\
\hline \multirow{2}{*}{$\begin{array}{l}\text { Big and Little Wood } \\
\text { River Footslopes and } \\
\text { Plains (proposed) }\end{array}$} & Federal & 56,622 & 29,421 & 757 & 86,799 & 2.0 \\
\hline & $\begin{array}{l}\text { Private or Non- } \\
\text { Federal }\end{array}$ & 27,243 & 15,017 & 92 & 42,352 & 1.0 \\
\hline \multirow{2}{*}{$\begin{array}{l}\text { Central Snake River } \\
\text { Plains (proposed) }\end{array}$} & Federal & 4,557 & 949 & 1 & 5,507 & 0.1 \\
\hline & $\begin{array}{l}\text { Private or Non- } \\
\text { Federal }\end{array}$ & 829 & 336 & 41 & 1,207 & 0.0 \\
\hline \multirow[t]{3}{*}{ Eastern Idaho Plateaus } & Federal & 193,563 & 63,495 & 3,173 & 260,231 & 6.0 \\
\hline & Indian Reservations & 57,725 & 15,120 & 2,216 & 75,061 & 1.7 \\
\hline & $\begin{array}{l}\text { Private or Non- } \\
\text { Federal }\end{array}$ & 314,950 & 105,948 & 75,772 & 496,670 & 11.4 \\
\hline \multirow[t]{2}{*}{ Great Salt Lake Area } & Federal & 86,118 & 24,887 & 2,657 & 113,663 & 2.6 \\
\hline & $\begin{array}{l}\text { Private or Non- } \\
\text { Federal }\end{array}$ & 44,230 & 20,983 & 23,323 & 88,536 & 2.0 \\
\hline \multirow{2}{*}{$\begin{array}{l}\text { Lost River Valleys and } \\
\text { Mountains }\end{array}$} & Federal & 164,767 & 82,669 & 261 & 247,697 & 5.7 \\
\hline & $\begin{array}{l}\text { Private or Non- } \\
\text { Federal }\end{array}$ & 5,438 & 2,154 & 204 & 7,796 & 0.2 \\
\hline \multirow{3}{*}{$\begin{array}{l}\text { Northern Rocky } \\
\text { Mountain Valleys }\end{array}$} & Federal & 1,056 & 1,293 & 1,664 & 4,013 & 0.1 \\
\hline & Indian Reservations & 0 & 0 & 0 & 0 & 0.0 \\
\hline & $\begin{array}{l}\text { Private or Non- } \\
\text { Federal }\end{array}$ & 12,363 & 14,279 & 22,716 & 49,358 & 1.1 \\
\hline \multirow{3}{*}{$\begin{array}{l}\text { Northern Rocky } \\
\text { Mountains }\end{array}$} & Federal & 859,135 & 708,934 & 8,928 & $1,576,996$ & 36.1 \\
\hline & Indian Reservations & 18,552 & 16,882 & 3,180 & 38,614 & 0.9 \\
\hline & $\begin{array}{l}\text { Private or Non- } \\
\text { Federal }\end{array}$ & 163,864 & 89,391 & 57,616 & 310,872 & 7.1 \\
\hline \multirow[t]{3}{*}{ Owyhee High Plateau } & Federal & 136,813 & 21,248 & 85 & 158,146 & 3.6 \\
\hline & Indian Reservations & 8,475 & 1,437 & 1 & 9,914 & 0.2 \\
\hline & $\begin{array}{l}\text { Private or Non- } \\
\text { Federal }\end{array}$ & 68,598 & 7,731 & 665 & 76,994 & 1.8 \\
\hline \multirow{3}{*}{$\begin{array}{l}\text { Palouse and Nez Perce } \\
\text { Prairies }\end{array}$} & Federal & 2,418 & 1,595 & 6 & 4,019 & 0.1 \\
\hline & Indian Reservations & 27,561 & 29,561 & 1,422 & 58,544 & 1.3 \\
\hline & $\begin{array}{l}\text { Private or Non- } \\
\text { Federal }\end{array}$ & 27,529 & 21,288 & 1,764 & 50,581 & 1.2 \\
\hline \multirow[t]{2}{*}{ Snake River Plains } & Federal & 3,687 & 68 & 0 & 3,756 & 0.1 \\
\hline & $\begin{array}{l}\text { Private or Non- } \\
\text { Federal }\end{array}$ & 3,157 & 92 & 0 & 3,249 & 0.1 \\
\hline \multirow{3}{*}{$\begin{array}{l}\text { Upper Snake River } \\
\text { Lava Plains and Hills }\end{array}$} & Federal & 157,056 & 38,725 & 662 & 196,443 & 4.5 \\
\hline & $\begin{array}{l}\text { Private or Non- } \\
\text { Federal }\end{array}$ & 226,480 & 47,414 & 13,631 & 287,525 & 6.6 \\
\hline & Federal & 6,396 & 963 & 106 & 7,465 & 0.2 \\
\hline \multirow{2}{*}{$\begin{array}{l}\text { Upper Snake River } \\
\text { Plains (proposed) }\end{array}$} & Indian Reservations & 766 & 203 & 267 & 1,236 & 0.0 \\
\hline & $\begin{array}{l}\text { Private or Non- } \\
\text { Federal }\end{array}$ & 7,107 & 2,884 & 4,075 & 14,066 & 0.3 \\
\hline \multirow{3}{*}{$\begin{array}{l}\text { Wasatch and Uinta } \\
\text { Mountains }\end{array}$} & Federal & 34,583 & 13,187 & 61 & 47,831 & 1.1 \\
\hline & $\begin{array}{l}\text { Private or Non- } \\
\text { Federal }\end{array}$ & 25,893 & 8,698 & 5,444 & 40,035 & 0.9 \\
\hline & \begin{tabular}{|r|} 
Sub Total \\
\end{tabular} & $2,747,530$ & $1,386,853$ & 230,791 & $4,365,174$ & \\
\hline
\end{tabular}




\begin{tabular}{|c|c|c|c|c|c|c|}
\hline $\begin{array}{l}\text { NRCS Major Land } \\
\text { Resource Area }\end{array}$ & Land Tenure & Shrubland & $\begin{array}{l}\text { Grasslands/ } \\
\text { Herbaceous }\end{array}$ & $\begin{array}{c}\text { Pasture/ } \\
\text { Hay }\end{array}$ & $\begin{array}{l}\text { Rangeland } \\
\text { Totals }\end{array}$ & $\begin{array}{l}\text { Percent } \\
\text { of Total }\end{array}$ \\
\hline \multicolumn{7}{|c|}{ Moderate Climatic Potential ( 230 to $460 \mathrm{~mm}$ ) } \\
\hline \multirow{2}{*}{$\begin{array}{l}\text { Big and Little Wood } \\
\text { River Footslopes and } \\
\text { Plains (proposed) }\end{array}$} & Federal & 360,770 & 39,236 & 1,796 & 401,803 & 6.3 \\
\hline & $\begin{array}{l}\text { Private or Non- } \\
\text { Federal }\end{array}$ & 102,483 & 43,547 & 41,038 & 187,068 & 3.0 \\
\hline \multirow{2}{*}{$\begin{array}{l}\text { Central Snake River } \\
\text { Plains (proposed) }\end{array}$} & Federal & 454,674 & 173,426 & 5,770 & 633,870 & 10.0 \\
\hline & $\begin{array}{l}\text { Private or Non- } \\
\text { Federal }\end{array}$ & 123,744 & 90,003 & 120,472 & 334,219 & 5.3 \\
\hline Columbia Plateau & $\begin{array}{l}\text { Private or Non- } \\
\text { Federal }\end{array}$ & 254 & 161 & 0 & 415 & 0.0 \\
\hline \multirow[t]{3}{*}{ Eastern Idaho Plateaus } & Federal & 51,017 & 9,328 & 2,619 & 62,963 & 1.0 \\
\hline & Indian Reservations & 37,630 & 12,363 & 4,195 & 54,189 & 0.9 \\
\hline & $\begin{array}{l}\text { Private or Non- } \\
\text { Federal }\end{array}$ & 140,491 & 57,646 & 79,381 & 277,519 & 4.4 \\
\hline \multirow[t]{2}{*}{ Great Salt Lake Area } & Federal & 51,368 & 23,305 & 1,955 & 76,627 & 1.2 \\
\hline & $\begin{array}{l}\text { Private or Non- } \\
\text { Federal }\end{array}$ & 22,751 & 14,359 & 28,563 & 65,674 & 1.0 \\
\hline \multirow{2}{*}{$\begin{array}{l}\text { Lost River Valleys and } \\
\text { Mountains }\end{array}$} & Federal & 447,226 & 100,518 & 6,059 & 553,802 & 8.7 \\
\hline & \begin{tabular}{|l|} 
Private or Non- \\
Federal \\
\end{tabular} & 83,993 & 42,639 & 37,332 & 163,964 & 2.6 \\
\hline \multirow{3}{*}{$\begin{array}{l}\text { Northern Rocky } \\
\text { Mountains }\end{array}$} & Federal & 157,023 & 82,342 & 3,006 & 242,371 & 3.8 \\
\hline & Indian Reservations & 173 & 23 & 0 & 195 & 0.0 \\
\hline & $\begin{array}{l}\text { Private or Non- } \\
\text { Federal }\end{array}$ & 56,930 & 22,603 & 8,798 & 88,331 & 1.4 \\
\hline \multirow[t]{3}{*}{ Owyhee High Plateau } & Federal & $1,032,573$ & 160,837 & 3,007 & $1,196,417$ & 18.9 \\
\hline & Indian Reservations & 35,668 & 7,698 & 1,398 & 44,764 & 0.7 \\
\hline & $\begin{array}{l}\text { Private or Non- } \\
\text { Federal }\end{array}$ & 194,881 & 33,059 & 13,933 & 241,873 & 3.8 \\
\hline \multirow{3}{*}{$\begin{array}{l}\text { Palouse and Nez Perce } \\
\text { Prairies }\end{array}$} & Federal & 1,780 & 624 & 0 & 2,404 & 0.0 \\
\hline & Indian Reservations & 5,851 & 5,000 & 0 & 10,852 & 0.2 \\
\hline & $\begin{array}{l}\text { Private or Non- } \\
\text { Federal } \\
\end{array}$ & 22,538 & 10,783 & 0 & 33,321 & 0.5 \\
\hline \multirow[t]{2}{*}{ Snake River Plains } & Federal & 250,264 & 95,717 & 3,502 & 349,483 & 5.5 \\
\hline & $\begin{array}{l}\text { Private or Non- } \\
\text { Federal }\end{array}$ & 93,020 & 33,739 & 93,506 & 220,265 & 3.5 \\
\hline \multirow{2}{*}{$\begin{array}{l}\text { Upper Snake River } \\
\text { Lava Plains and Hills }\end{array}$} & Federal & 38,711 & 10,245 & 326 & 49,283 & 0.8 \\
\hline & \begin{tabular}{|l} 
Private or Non- \\
Federal \\
\end{tabular} & 115,130 & 26,065 & 11,503 & 152,698 & 2.4 \\
\hline \multirow{3}{*}{$\begin{array}{l}\text { Upper Snake River } \\
\text { Plains (proposed) }\end{array}$} & Federal & 394,244 & 82,842 & 2,973 & 480,059 & 7.6 \\
\hline & Indian Reservations & 17,718 & 9,136 & 6,485 & 33,339 & 0.5 \\
\hline & $\begin{array}{l}\text { Private or Non- } \\
\text { Federal }\end{array}$ & 162,794 & 85,580 & 122,121 & 370,495 & 5.8 \\
\hline \multirow{3}{*}{$\begin{array}{l}\text { Wasatch and Uinta } \\
\text { Mountains }\end{array}$} & Federal & 1,237 & 295 & 86 & 1,619 & 0.0 \\
\hline & \begin{tabular}{|l|} 
Private or Non- \\
Federal \\
\end{tabular} & 5,737 & 2,328 & 3,317 & 11,382 & 0.2 \\
\hline & \begin{tabular}{|l|} 
Sub Total \\
\end{tabular} & $4,462,675$ & $1,275,446$ & 603,141 & $6,341,262$ & \\
\hline \multicolumn{7}{|c|}{ Low Climatic Potential (130 to $230 \mathrm{~mm}$ ) } \\
\hline \multirow{2}{*}{$\begin{array}{l}\text { Central Snake River } \\
\text { Plains (proposed) }\end{array}$} & Federal & 8,437 & 2,317 & 6 & 10,759 & 2.3 \\
\hline & $\begin{array}{l}\text { Private or Non- } \\
\text { Federal }\end{array}$ & 1,269 & 401 & 33 & 1,703 & 0.4 \\
\hline Lost River Valleys and & Federal & 94,558 & 24,520 & 2,340 & 121,418 & 26.2 \\
\hline
\end{tabular}




\begin{tabular}{|c|c|c|c|c|c|c|}
\hline $\begin{array}{l}\text { NRCS Major Land } \\
\text { Resource Area }\end{array}$ & Land Tenure & Shrubland & $\begin{array}{l}\text { Grasslands/ } \\
\text { Herbaceous }\end{array}$ & $\begin{array}{c}\text { Pasture/ } \\
\text { Hay }\end{array}$ & $\begin{array}{l}\text { Rangeland } \\
\text { Totals }\end{array}$ & $\begin{array}{l}\text { Percent } \\
\text { of Total }\end{array}$ \\
\hline Mountains & $\begin{array}{l}\text { Private or Non- } \\
\text { Federal }\end{array}$ & 15,689 & 10,758 & 17,262 & 43,708 & 9.4 \\
\hline \multirow{2}{*}{$\begin{array}{l}\text { Northern Rocky } \\
\text { Mountains }\end{array}$} & Federal & 6,229 & 2,053 & 217 & 8,498 & 1.8 \\
\hline & $\begin{array}{l}\text { Private or Non- } \\
\text { Federal }\end{array}$ & 1,129 & 506 & 395 & 2,030 & 0.4 \\
\hline \multirow[t]{2}{*}{ Owyhee High Plateau } & Federal & 68,142 & 21,819 & 84 & 90,044 & 19.4 \\
\hline & $\begin{array}{l}\text { Private or Non- } \\
\text { Federal }\end{array}$ & 3,705 & 1,029 & 1 & 4,735 & 1.0 \\
\hline \multirow[t]{2}{*}{ Snake River Plains } & Federal & 81,218 & 46,044 & 3,122 & 130,384 & 28.1 \\
\hline & $\begin{array}{l}\text { Private or Non- } \\
\text { Federal }\end{array}$ & 13,744 & 10,617 & 6,208 & 30,569 & 6.6 \\
\hline \multirow{3}{*}{$\begin{array}{l}\text { Upper Snake River } \\
\text { Plains (proposed) }\end{array}$} & Federal & 18,605 & 748 & 1 & 19,355 & 4.2 \\
\hline & Sub Total & 312,724 & 120,809 & 29,670 & 463,203 & \\
\hline & Grand Total & $7,522,930$ & $2,783,108$ & 863,602 & $11,169,640$ & \\
\hline
\end{tabular}

Table 2. Total hectares of rangeland cover types identified in Major Land Resource Areas (MLRA) in Idaho.

\begin{tabular}{|l|r|}
\hline \multicolumn{1}{|c|}{ MLRA NAME } & Rangeland (ha) \\
\hline Northern Rocky Mountains & 2267908 \\
\hline Owyhee High Plateau & 1822887 \\
\hline Eastern Idaho Plateaus & 1226633 \\
\hline Lost River Valleys and Mountains & 1138385 \\
\hline Central Snake River Plains (proposed) & 987265 \\
\hline Upper Snake River Plains (proposed) & 926014 \\
\hline Snake River Plains & 737706 \\
\hline Big and Little Wood River Footslopes and Plains (proposed) & 718021 \\
\hline Upper Snake River Lava Plains and Hills & 685948 \\
\hline Great Salt Lake Area & 344500 \\
\hline Palouse and Nez Perce Prairies & 159720 \\
\hline Wasatch and Uinta Mountains & 100866 \\
\hline Northern Rocky Mountain Valleys & 53371 \\
\hline Columbia Plateau & 415 \\
\hline
\end{tabular}


Table 3. Rangeland (ha) by land cover class and sums of the classes for Major Land Resource Area (MLRA) and land tenure class grouped according to Climatic Potential for carbon sequestration in Montana. Percent of total reflects the percent of total rangeland occupied by the MLRA and Land Tenure class within the climatic potential grouping.

\begin{tabular}{|c|c|c|c|c|c|c|}
\hline $\begin{array}{l}\text { NRCS Major Land } \\
\text { Resource Area }\end{array}$ & Land Tenure & Shrubland & $\begin{array}{l}\text { Grasslands/ } \\
\text { Herbaceous }\end{array}$ & Pasture/Hay & $\begin{array}{l}\text { Rangeland } \\
\text { Totals }\end{array}$ & $\begin{array}{c}\text { Percent } \\
\text { of } \\
\text { Total }\end{array}$ \\
\hline \multicolumn{7}{|c|}{ High Climatic Potential $(>460 \mathrm{~mm})$} \\
\hline \multirow[t]{2}{*}{ Brown Glaciated Plain } & Indian Reservations & 1,044 & 47,497 & 383 & 48,924 & 1.3 \\
\hline & Private or Non-Federal & 154 & 6,993 & 59 & 7,206 & 0.2 \\
\hline \multirow{2}{*}{$\begin{array}{l}\text { Northern } \\
\text { Intermountain Desertic } \\
\text { Basins }\end{array}$} & Federal & 1,798 & 2,606 & 0 & 4,404 & 0.1 \\
\hline & Private or Non-Federal & 1,639 & 1,934 & 0 & 3,573 & 0.1 \\
\hline \multirow{3}{*}{$\begin{array}{l}\text { Northern Rocky } \\
\text { Mountain Foothills }\end{array}$} & Federal & 11,102 & 42,284 & 39 & 53,425 & 1.5 \\
\hline & Indian Reservations & 30,045 & 138,512 & 5,937 & 174,495 & 4.8 \\
\hline & Private or Non-Federal & 51,449 & 464,005 & 15,309 & 530,763 & 14.6 \\
\hline \multirow{3}{*}{$\begin{array}{l}\text { Northern Rocky } \\
\text { Mountain Valleys }\end{array}$} & Federal & 47,410 & 53,485 & 3,318 & 104,213 & 2.9 \\
\hline & Indian Reservations & 3,492 & 15,622 & 2,129 & 21,243 & 0.6 \\
\hline & Private or Non-Federal & 65,074 & 185,917 & 47,999 & 298,990 & 8.2 \\
\hline \multirow{3}{*}{$\begin{array}{l}\text { Northern Rocky } \\
\text { Mountains }\end{array}$} & Federal & 574,907 & 776,050 & 4,591 & $1,355,548$ & 37.4 \\
\hline & Indian Reservations & 30,912 & 107,895 & 6,724 & 145,531 & 4.0 \\
\hline & Private or Non-Federal & 166,339 & 567,570 & 15,946 & 749,855 & 20.7 \\
\hline \multirow{3}{*}{$\begin{array}{l}\text { Northern Rolling High } \\
\text { Plains; Northern Part }\end{array}$} & Federal & 147 & 323 & 0 & 469 & 0.0 \\
\hline & Indian Reservations & 11,539 & 72,612 & 1,957 & 86,108 & 2.4 \\
\hline & Private or Non-Federal & 3,139 & 17,532 & 1,053 & 21,724 & $\overline{0.6}$ \\
\hline \multirow{3}{*}{$\begin{array}{l}\text { Northern Rolling High } \\
\text { Plains; Southern Part }\end{array}$} & Federal & 171 & 2,228 & 12 & 2,411 & 0.1 \\
\hline & Private or Non-Federal & 1,359 & 15,404 & 299 & 17,062 & 0.5 \\
\hline & \begin{tabular}{|r|} 
Sub Total \\
\end{tabular} & $1,001,720$ & $2,518,468$ & 105,755 & $3,625,943$ & \\
\hline \multicolumn{7}{|c|}{ Moderate Climatic Potential ( 230 to $460 \mathrm{~mm}$ ) } \\
\hline \multirow[t]{3}{*}{ Brown Glaciated Plain } & Federal & 43,303 & 649,228 & 3,950 & 696,481 & 4.0 \\
\hline & Indian Reservations & 16,450 & 374,909 & 7,319 & 398,679 & 2.3 \\
\hline & Private or Non-Federal & 90,151 & $1,533,435$ & 125,049 & $1,748,636$ & 9.9 \\
\hline \multirow{3}{*}{$\begin{array}{l}\text { Northern Dark Brown } \\
\text { Glaciated Plains }\end{array}$} & Federal & 3,284 & 11,916 & 175 & 15,375 & 0.1 \\
\hline & Indian Reservations & 32,783 & 173,152 & 3,429 & 209,364 & 1.2 \\
\hline & Private or Non-Federal & 103,209 & 389,768 & 37,846 & 530,823 & 3.0 \\
\hline \multirow{2}{*}{$\begin{array}{l}\text { Northern } \\
\text { Intermountain Desertic } \\
\text { Basins }\end{array}$} & Federal & 20,040 & 3,574 & 0 & 23,614 & 0.1 \\
\hline & Private or Non-Federal & 24,763 & 6,049 & 1,423 & 32,235 & 0.2 \\
\hline \multirow{3}{*}{$\begin{array}{l}\text { Northern Rocky } \\
\text { Mountain Foothills }\end{array}$} & Federal & 31,919 & 57,980 & 172 & 90,071 & 0.5 \\
\hline & Indian Reservations & 26,924 & 210,946 & 5,485 & 243,355 & 1.4 \\
\hline & Private or Non-Federal & 72,222 & 983,168 & 58,110 & $1,113,500$ & 6.3 \\
\hline \multirow{3}{*}{$\begin{array}{l}\text { Northern Rocky } \\
\text { Mountain Valleys }\end{array}$} & Federal & 51,065 & 84,188 & 4,337 & 139,590 & 0.8 \\
\hline & Indian Reservations & 8,313 & 53,955 & 30,467 & 92,735 & 0.5 \\
\hline & Private or Non-Federal & 177,486 & 728,161 & 222,278 & $1,127,925$ & 6.4 \\
\hline \multirow{2}{*}{$\begin{array}{l}\text { Northern Rocky } \\
\text { Mountains }\end{array}$} & Federal & 146,928 & 189,265 & 2,490 & 338,683 & 1.9 \\
\hline & Indian Reservations & 15,034 & 39,315 & 10,493 & 64,841 & 0.4 \\
\hline
\end{tabular}




\begin{tabular}{|c|c|c|c|c|c|c|}
\hline $\begin{array}{l}\text { NRCS Major Land } \\
\text { Resource Area } \\
\end{array}$ & Land Tenure & Shrubland & $\begin{array}{l}\text { Grasslands/ } \\
\text { Herbaceous }\end{array}$ & Pasture/Hay & $\begin{array}{c}\text { Rangeland } \\
\text { Totals }\end{array}$ & $\begin{array}{c}\text { Percent } \\
\text { of } \\
\text { Total }\end{array}$ \\
\hline & Private or Non-Federal & 199,634 & 654,437 & 54,658 & 908,728 & 5.2 \\
\hline \multirow{2}{*}{$\begin{array}{l}\text { Northern Rolling High } \\
\text { Plains; Eastern Part }\end{array}$} & Federal & 4,620 & 10,355 & 52 & 15,027 & 0.1 \\
\hline & Private or Non-Federal & 11,434 & 35,177 & 2,490 & 49,102 & 0.3 \\
\hline \multirow{3}{*}{$\begin{array}{l}\text { Northern Rolling High } \\
\text { Plains; Northern Part }\end{array}$} & Federal & 310,851 & $1,340,477$ & 3,688 & $1,655,017$ & 9.4 \\
\hline & Indian Reservations & 54,433 & 436,462 & 15,263 & 506,158 & 2.9 \\
\hline & Private or Non-Federal & 648,515 & $5,506,180$ & 145,777 & $6,300,471$ & 35.8 \\
\hline \multirow{3}{*}{$\begin{array}{l}\text { Northern Rolling High } \\
\text { Plains; Southern Part }\end{array}$} & Federal & 2,479 & 10,565 & 45 & 13,090 & 0.1 \\
\hline & Indian Reservations & 501 & 2,426 & 0 & 2,927 & 0.0 \\
\hline & Private or Non-Federal & 25,141 & 104,513 & 1,723 & 131,377 & 0.7 \\
\hline \multirow{2}{*}{$\begin{array}{l}\text { Pierre Shale Plains and } \\
\text { Badland }\end{array}$} & Federal & 9,238 & 25,657 & 107 & 35,002 & 0.2 \\
\hline & Private or Non-Federal & 6,909 & 65,461 & 2,117 & 74,487 & 0.4 \\
\hline \multirow{2}{*}{$\begin{array}{l}\text { Pierre Shale Plains; } \\
\text { Northern Part }\end{array}$} & Federal & 50,877 & 149,794 & 724 & 201,395 & 1.1 \\
\hline & Private or Non-Federal & 86,067 & 449,058 & 10,616 & 545,740 & 3.1 \\
\hline \multirow{3}{*}{$\begin{array}{l}\text { Rolling Soft Shale } \\
\text { Plain }\end{array}$} & Federal & 227 & 2,763 & 138 & 3,128 & 0.0 \\
\hline & Private or Non-Federal & 34,437 & 224,796 & 24,914 & 284,147 & 1.6 \\
\hline & \begin{tabular}{|r|} 
Sub Total \\
\end{tabular} & $2,309,237$ & $14,507,129$ & 775,335 & $17,591,700$ & \\
\hline \multicolumn{7}{|c|}{ Low Climatic Potential (130 to $230 \mathrm{~mm}$ ) } \\
\hline \multirow{2}{*}{$\begin{array}{l}\text { Northern } \\
\text { Intermountain Desertic } \\
\text { Basins }\end{array}$} & Federal & 9,260 & $\begin{array}{r}535 \\
\end{array}$ & 20 & 9,815 & 33.5 \\
\hline & Private or Non-Federal & 8,516 & 1,594 & 1,047 & 11,156 & 38.0 \\
\hline \multirow{2}{*}{$\begin{array}{l}\text { Northern Rocky } \\
\text { Mountain Foothills }\end{array}$} & Federal & 5,554 & 185 & 40 & 5,778 & 19.7 \\
\hline & Private or Non-Federal & 471 & 7 & 0 & 478 & 1.6 \\
\hline \multirow{4}{*}{$\begin{array}{l}\text { Northern Rocky } \\
\text { Mountains } \\
\end{array}$} & Federal & 1,780 & 254 & 0 & 2,034 & 6.9 \\
\hline & Indian Reservations & 72 & 6 & 0 & 77 & 0.3 \\
\hline & $\begin{array}{r}\text { Sub Total } \\
\end{array}$ & 25,652 & 2,581 & 1,106 & 29,339 & \\
\hline & Grand Total & $3,336,609$ & $17,028,178$ & 882,196 & $21,246,983$ & \\
\hline
\end{tabular}


Table 4. Total hectares of rangeland cover types identified in Major Land Resource Areas (MLRA) in Montana.

\begin{tabular}{|l|r|}
\hline \multicolumn{1}{|c|}{ MLRA NAME } & Rangeland \\
\hline Northern Rolling High Plains; Northern Part & $8,569,948$ \\
\hline Northern Rocky Mountains & $3,565,297$ \\
\hline Brown Glaciated Plain & $2,899,925$ \\
\hline Northern Rocky Mountain Foothills & $2,211,864$ \\
\hline Northern Rocky Mountain Valleys & $1,784,696$ \\
\hline Northern Dark Brown Glaciated Plains & 755,562 \\
\hline Pierre Shale Plains; Northern Part & 747,135 \\
\hline Rolling Soft Shale Plain & 287,276 \\
\hline Northern Rolling High Plains; Southern Part & 166,867 \\
\hline Pierre Shale Plains and Badlands & 109,489 \\
\hline Northern Intermountain Desertic Basins & 84,797 \\
\hline Northern Rolling High Plains; Eastern Part & 64,128 \\
\hline
\end{tabular}


Table 5. Rangeland (ha) by land cover class and sums of the classes for Major Land Resource Area (MLRA) and land tenure class grouped according to Climatic Potential for carbon sequestration in South Dakota. Percent of total reflects the percent of total rangeland occupied by the MLRA and Land Tenure class within the Climatic Potential grouping.

\begin{tabular}{|c|c|c|c|c|c|c|}
\hline $\begin{array}{l}\text { NRCS Major Land } \\
\text { Resource Area }\end{array}$ & Land Tenure & Shrubland & $\begin{array}{l}\text { Grasslands/ } \\
\text { Herbaceous }\end{array}$ & Pasture/Hay & $\begin{array}{c}\text { Rangeland } \\
\text { Totals }\end{array}$ & $\begin{array}{c}\text { Percent } \\
\text { of } \\
\text { Total }\end{array}$ \\
\hline \multicolumn{7}{|c|}{ High Climatic Potential (>460 mm) } \\
\hline \multirow[t]{2}{*}{ Black Hills } & Federal & 126 & 63,784 & 11,469 & 75,379 & 1.1 \\
\hline & Private or Non-Federal & 60 & 19,915 & 1,942 & 21,917 & 0.3 \\
\hline \multirow{2}{*}{$\begin{array}{l}\text { Black Hills Foot } \\
\text { Slopes }\end{array}$} & Federal & 19 & 10,776 & 689 & 11,483 & 0.2 \\
\hline & Private or Non-Federal & 713 & 64,476 & 25,848 & 91,037 & 1.4 \\
\hline \multirow{3}{*}{$\begin{array}{l}\text { Central Black } \\
\text { Glaciated Plains }\end{array}$} & Federal & 0 & 278 & 1,638 & 1,916 & 0.0 \\
\hline & Indian Reservations & 0 & 177 & 1,575 & 1,751 & 0.0 \\
\hline & Private or Non-Federal & 45 & 40,388 & 171,125 & 211,558 & 3.2 \\
\hline $\begin{array}{l}\text { Central Dark Brown } \\
\text { Glaciated Plains }\end{array}$ & Private or Non-Federal & 1,424 & 319,620 & 237,937 & 558,981 & 8.3 \\
\hline \multirow{2}{*}{$\begin{array}{l}\text { Dakota-Nebraska } \\
\text { Eroded Tableland }\end{array}$} & Indian Reservations & 0 & 152,108 & 19,518 & 171,626 & 2.6 \\
\hline & Private or Non-Federal & 0 & 132,641 & 46,360 & 179,002 & 2.7 \\
\hline $\begin{array}{l}\text { Iowa and Missouri } \\
\text { Deep Loess Hills }\end{array}$ & Private or Non-Federal & 1 & 1,618 & 31,220 & 32,839 & 0.5 \\
\hline \multirow{3}{*}{$\begin{array}{l}\text { Mixed Sandy and Silty } \\
\text { Tableland }\end{array}$} & Federal & 0 & 1,489 & 1,546 & 3,036 & 0.0 \\
\hline & Indian Reservations & 0 & 264,652 & 44,531 & 309,184 & 4.6 \\
\hline & Private or Non-Federal & 0 & 181,193 & 47,756 & 228,949 & 3.4 \\
\hline \multirow[t]{3}{*}{ Nebraska Sand Hills } & Federal & 0 & 368 & 0 & 368 & 0.0 \\
\hline & Indian Reservations & 0 & 43,193 & 1,426 & 44,618 & 0.7 \\
\hline & Private or Non-Federal & 0 & 69,855 & 897 & 70,751 & 1.1 \\
\hline \multirow{3}{*}{$\begin{array}{l}\text { Northern Rolling Pierre } \\
\text { Shale Plains }\end{array}$} & Federal & 97 & 85,743 & 1,456 & 87,295 & 1.3 \\
\hline & Indian Reservations & 1,556 & 235,250 & 1,848 & 238,655 & 3.6 \\
\hline & Private or Non-Federal & 1,176 & 758,973 & 41,274 & 801,423 & 11.9 \\
\hline \multirow{3}{*}{$\begin{array}{l}\text { Pierre Shale Plains and } \\
\text { Badlands }\end{array}$} & Federal & 8 & 2,085 & 437 & 2,530 & 0.0 \\
\hline & Indian Reservations & 0 & 77,028 & 8,188 & 85,216 & 1.3 \\
\hline & Private or Non-Federal & 1,151 & 139,081 & 17,957 & 158,189 & 2.4 \\
\hline \multirow{3}{*}{$\begin{array}{l}\text { Red River Valley of } \\
\text { the North }\end{array}$} & Federal & 0 & 11 & 17 & 28 & 0.0 \\
\hline & Indian Reservations & 0 & 3 & 1,620 & 1,624 & 0.0 \\
\hline & Private or Non-Federal & 0 & 0 & 190 & 190 & 0.0 \\
\hline \multirow{2}{*}{$\begin{array}{l}\text { Rolling Soft Shale } \\
\text { Plain }\end{array}$} & Indian Reservations & 286 & 98,987 & 2,147 & 101,420 & 1.5 \\
\hline & Private or Non-Federal & 0 & 796 & 416 & 1,213 & 0.0 \\
\hline \multirow[t]{3}{*}{ Rolling Till Prairie } & Federal & 0 & 382 & 1,218 & 1,600 & 0.0 \\
\hline & Indian Reservations & 1 & 21,170 & 113,190 & 134,360 & 2.0 \\
\hline & Private or Non-Federal & 89 & 60,265 & 510,783 & 571,137 & 8.5 \\
\hline \multirow{3}{*}{$\begin{array}{l}\text { Southern Black } \\
\text { Glaciated Plains }\end{array}$} & Federal & 0 & 1,212 & 496 & 1,709 & 0.0 \\
\hline & Indian Reservations & 0 & 15,080 & 54,100 & 69,180 & 1.0 \\
\hline & Private or Non-Federal & 466 & 151,138 & 733,494 & 885,098 & 13.2 \\
\hline \multirow{3}{*}{$\begin{array}{l}\text { Southern Dark Brown } \\
\text { Glaciated Plains }\end{array}$} & Federal & 0 & 785 & 14 & 799 & 0.0 \\
\hline & Indian Reservations & 30 & 15,325 & 161 & 15,516 & 0.2 \\
\hline & Private or Non-Federal & 399 & 429,966 & 150,230 & 580,595 & 8.6 \\
\hline
\end{tabular}




\begin{tabular}{|c|c|c|c|c|c|c|}
\hline $\begin{array}{c}\text { NRCS Major Land } \\
\text { Resource Area } \\
\end{array}$ & Land Tenure & Shrubland & $\begin{array}{l}\text { Grasslands/ } \\
\text { Herbaceous }\end{array}$ & Pasture/Hay & $\begin{array}{c}\text { Rangeland } \\
\text { Totals }\end{array}$ & $\begin{array}{c}\text { Percent } \\
\text { of } \\
\text { Total }\end{array}$ \\
\hline \multicolumn{2}{|c|}{ Southern Rolling Pierre Federal } & 27 & 4,694 & 1,024 & 5,745 & 0.1 \\
\hline \multirow[t]{2}{*}{ Shale Plains } & Indian Reservations & 75 & 86,247 & 11,763 & 98,085 & 1.5 \\
\hline & Private or Non-Federal & 27 & 286,624 & 87,998 & 374,649 & 5.6 \\
\hline \multirow[t]{4}{*}{ Till Plains } & Federal & 0 & 1,018 & 1,482 & 2,501 & 0.0 \\
\hline & Indian Reservations & 0 & 371 & 822 & 1,193 & 0.0 \\
\hline & Private or Non-Federal & 11 & 33,390 & 448,383 & 481,784 & 7.2 \\
\hline & \begin{tabular}{|r|} 
Sub Total \\
\end{tabular} & $\mathbf{7 , 7 8 8}$ & $3,872,157$ & $2,836,184$ & $6,716,129$ & \\
\hline \multicolumn{7}{|c|}{ Moderate Climatic Potential ( 230 to $460 \mathrm{~mm}$ ) } \\
\hline \multirow[t]{2}{*}{ Black Hills } & Federal & 303 & 2,524 & 53 & 2,881 & 0.1 \\
\hline & Private or Non-Federal & 631 & 4,036 & 46 & 4,713 & 0.1 \\
\hline \multirow{2}{*}{$\begin{array}{l}\text { Black Hills Foot } \\
\text { Slopes }\end{array}$} & Federal & 878 & 34,954 & 686 & 36,518 & 0.7 \\
\hline & Private or Non-Federal & 3,594 & 39,465 & 1,743 & 44,802 & 0.8 \\
\hline \multirow{2}{*}{$\begin{array}{l}\text { Central Dark Brown } \\
\text { Glaciated Plains } \\
\end{array}$} & Federal & 0 & 17 & 0 & 17 & 0.0 \\
\hline & Private or Non-Federal & 137 & 64,316 & 7,275 & 71,728 & 1.3 \\
\hline \multirow{3}{*}{$\begin{array}{l}\text { Mixed Sandy and Silty } \\
\text { Tableland }\end{array}$} & Federal & 0 & 10,346 & 64 & 10,410 & 0.2 \\
\hline & Indian Reservations & 0 & 183,648 & 5,698 & 189,345 & 3.5 \\
\hline & Private or Non-Federal & 0 & 9 & 5 & 15 & 0.0 \\
\hline \multirow{3}{*}{$\begin{array}{l}\text { Northern Rolling High } \\
\text { Plains; Eastern Part }\end{array}$} & Federal & 6,582 & 14,982 & 461 & 22,026 & 0.4 \\
\hline & Indian Reservations & 399 & 13,283 & 0 & 13,681 & 0.3 \\
\hline & Private or Non-Federal & 207,120 & 802,760 & 16,546 & $1,026,425$ & 18.8 \\
\hline \multirow{3}{*}{$\begin{array}{l}\text { Northern Rolling Pierre } \\
\text { Shale Plains }\end{array}$} & Federal & 296 & 57,655 & 1,690 & 59,641 & 1.1 \\
\hline & Indian Reservations & 3,225 & 383,905 & 833 & 387,962 & 7.1 \\
\hline & Private or Non-Federal & 739 & 557,318 & 4,603 & 562,659 & 10.3 \\
\hline \multirow{3}{*}{$\begin{array}{l}\text { Pierre Shale Plains and } \\
\text { Badlands }\end{array}$} & Federal & 24,426 & 531,493 & 12,968 & 568,887 & 10.4 \\
\hline & Indian Reservations & 0 & 154,950 & 3,880 & 158,830 & 2.9 \\
\hline & Private or Non-Federal & 105,203 & 935,981 & 68,558 & $1,109,742$ & 20.4 \\
\hline \multirow{3}{*}{$\begin{array}{l}\text { Rolling Soft Shale } \\
\text { Plain }\end{array}$} & Federal & 21,382 & 121,743 & 3,273 & 146,399 & 2.7 \\
\hline & Indian Reservations & 27,392 & 653,331 & 6,522 & 687,244 & 12.6 \\
\hline & Private or Non-Federal & 69,753 & 210,147 & 31,554 & 311,454 & 5.7 \\
\hline \multirow{4}{*}{$\begin{array}{l}\text { Southern Dark Brown } \\
\text { Glaciated Plains }\end{array}$} & Federal & 2 & 3,114 & 107 & 3,223 & 0.1 \\
\hline & Private or Non-Federal & 10 & 27,258 & 2,694 & 29,962 & 0.5 \\
\hline & \begin{tabular}{|r|} 
Sub Total \\
\end{tabular} & 472,070 & $4,807,234$ & 169,260 & $5,448,564$ & \\
\hline & Grand Total & 479,858 & $8,679,391$ & $3,005,444$ & $12,164,693$ & \\
\hline
\end{tabular}


Table 6. Total hectares of rangeland cover types identified in Major Land Resource Areas (MLRA) in South Dakota.

\begin{tabular}{|l|r|}
\hline \multicolumn{1}{|c|}{ MLRA NAME } & Rangeland \\
\hline Northern Rolling Pierre Shale Plains & $2,137,636$ \\
\hline Pierre Shale Plains and Badlands & $2,083,394$ \\
\hline Rolling Soft Shale Plain & $1,247,729$ \\
\hline Northern Rolling High Plains; Eastern Part & $1,062,133$ \\
\hline Southern Black Glaciated Plains & 955,986 \\
\hline Mixed Sandy and Silty Tableland & 740,938 \\
\hline Rolling Till Prairie & 707,097 \\
\hline Central Dark Brown Glaciated Plains & 630,725 \\
\hline Southern Dark Brown Glaciated Plains & 630,095 \\
\hline Till Plains & 485,477 \\
\hline Southern Rolling Pierre Shale Plains & 478,480 \\
\hline Dakota-Nebraska Eroded Tableland & 350,628 \\
\hline Central Black Glaciated Plains & 215,226 \\
\hline Black Hills Foot Slopes & 183,841 \\
\hline Nebraska Sand Hills & 115,738 \\
\hline Black Hills & 104,890 \\
\hline Iowa and Missouri Deep Loess Hills & 32,839 \\
\hline Red River Valley of the North & 1,842 \\
\hline
\end{tabular}

Table 7. Rangeland (ha) for each state in the Big Sky Project by climatic potential (annual precipitation) and land tenure class. Federal lands are not included since they will most likely not be included in carbon sequestration programs.

\begin{tabular}{|c|c|c|c|c|}
\hline Land Tenure Class & Idaho & Montana & South Dakota & \begin{tabular}{|l} 
Big Sky \\
Region Totals
\end{tabular} \\
\hline \multicolumn{5}{|c|}{ High Climatic Potential (>460 mm) } \\
\hline Indian Reservations & 183,369 & 476,300 & $1,272,428$ & $1,932,096$ \\
\hline Private or Other Non-Federal & $1,469,240$ & $1,629,173$ & $5,249,313$ & $8,347,725$ \\
\hline \multicolumn{5}{|c|}{ Moderate Climatic Potential ( 230 to $460 \mathrm{~mm}$ ) } \\
\hline Indian Reservations & 143,339 & $1,518,059$ & $1,437,063$ & $3,098,461$ \\
\hline Private or Other Non-Federal & $2,147,225$ & $12,847,170$ & $3,161,500$ & $18,155,895$ \\
\hline \multicolumn{5}{|c|}{ Low Climatic Potential $(130$ to $230 \mathrm{~mm})$} \\
\hline Indian Reservations & 0 & 77 & 0 & 77 \\
\hline Private or Other Non-Federal & 82,745 & 11,635 & 0 & 94,380 \\
\hline Totals & $3,943,172$ & $16,470,702$ & $11,120,304$ & $31,534,178$ \\
\hline
\end{tabular}


Table 8. Prediction statistics for the independent validation set predicted from the equation derived from the 107 analyzed samples and cross validation results obtained from combining the validation set with the calibration set. Values are percentages.

\begin{tabular}{|c|c|c|c|c|c|c|c|c|c|}
\hline \multirow[b]{2}{*}{ Property } & \multicolumn{4}{|c|}{ Independent Validation } & \multicolumn{5}{|c|}{ Cross Validation Combined Set } \\
\hline & $\mathrm{n}$ & RSQ & SEP & BIAS & $\mathrm{n}$ & Mean & SD & SECV & RSQ \\
\hline Inorganic Carbon & 25 & 0.966 & 0.211 & -0.060 & 120 & 1.85 & 2.11 & 0.279 & 0.98 \\
\hline Total Carbon & 25 & 0.918 & 0.329 & -0.016 & 120 & 3.46 & 1.90 & 0.313 & 0.97 \\
\hline Organic Carbon & 25 & 0.859 & 0.278 & 0.090 & 120 & 1.63 & 0.73 & 0.266 & 0.87 \\
\hline Total Nitrogen & 25 & 0.945 & 0.018 & 0.006 & 118 & 0.17 & 0.012 & 0.016 & 0.94 \\
\hline
\end{tabular}

Table 9. Cross Validation Results for Final NIR Throckmorton Equation.

\begin{tabular}{llllll}
\hline Property & $\mathrm{n}$ & Mean & SD & SECV & RSQ \\
\hline IC & 186 & 1.71 & 1.83 & 0.297 & 0.97 \\
TC & 188 & 3.32 & 1.75 & 0.323 & 0.97 \\
OC & 185 & 1.56 & 0.64 & 0.251 & 0.85 \\
TN & 118 & 0.17 & 0.012 & 0.016 & 0.94 \\
\hline
\end{tabular}

Table 10. Cross Validation Results for Second General Organic Carbon and Total Nitrogen Equation

\begin{tabular}{|l|c|c|c|c|c|}
\hline Property & $\mathrm{n}$ & Mean & SD & SECV & RSQ \\
\hline Organic Carbon & 1110 & 2.10 & 1.10 & 0.36 & 0.89 \\
\hline Total Nitrogen & 951 & 0.20 & 0.093 & 0.034 & 0.86 \\
\hline
\end{tabular}

Table 11. Cross validation predictions of selected carbon fractions.

\begin{tabular}{lllllll}
\hline Property & $\mathrm{n}$ & Mean* & SD & SECV & RSQ & Bias \\
\hline Glomalin & 111 & 0.51 & 0.36 & 0.122 & 0.89 & -0.07 \\
POM & 142 & 0.95 & 1.02 & 0.556 & 0.71 & -0.33 \\
Amino sugar & 131 & 201.54 & 71.26 & 33.26 & 0.78 & 19.96 \\
B -glucosaminidase & 138 & 26.32 & 18.61 & 10.73 & 0.67 & -6.44 \\
B- glucosidase & 130 & 75.94 & 46.76 & 29.10 & 0.61 & -17.46 \\
\hline
\end{tabular}

*units for glomalin and POM are $\mathrm{mg} \mathrm{g}^{-1}$ and $\mu \mathrm{g} \mathrm{g}^{-1}$ for amino sugar, B -glucosaminidase and B-glucosidase. 
The next Big Sky partnership meeting will be held August 24-26, 2004 in Idaho Falls. We will meet in the Riverside room (TAB 350) at the Center for Higher Education (CHE), where Bob Smith (208-282-7954) is located. There is a SUB in an adjacent building where drinks, snacks, etc. are available. There is no need for badges, but the participants will need parking passes (INEEL will take care of this).

Working lunches will provide some flexibility in the presentation times.

\begin{tabular}{|c|c|c|}
\hline \multicolumn{3}{|c|}{$\begin{array}{c}\text { Big Sky Carbon Sequestration Regional Partnership Agenda } \\
\text { TAB } 350 \text { Conference Room at the Center for Higher Education }\end{array}$} \\
\hline \multicolumn{3}{|c|}{ Day 1 - Monday, August 23 (Travel Day) } \\
\hline \multicolumn{3}{|c|}{ Day 2 -Tuesday, August 24} \\
\hline Time & Topic & Presenters \\
\hline $7: 45-8: 00 \mathrm{AM}$ & Coffee Reception & \\
\hline $8: 00-8: 30 \mathrm{AM}$ & Welcome and INEEL R\&D Overview & $\begin{array}{l}\text { Paul Kearns PhD, Lab Director for } \\
\text { INEEL }\end{array}$ \\
\hline $8: 30-9: 30 \mathrm{AM}$ & NETL Program Office & John Litynski, DOE-HQ \\
\hline $9: 30-10: 00$ AM & Review Agenda/Meeting goals & Susan Capalbo, Partnership PI \\
\hline 10:00 AM - 12:00 & Progress Report (Geologic) & INEEL, U of I, BSU, LANL \\
\hline 12:00-1:00 PM & Working Lunch & \\
\hline 1:00-2:30 PM & Progress Reports (GIS) & INEEL, SDSMT, LANL \\
\hline $2: 30-3: 30 \mathrm{PM}$ & Progress Reports (MMV, Adv. Technologies) & LANL \\
\hline $3: 30-5: 30$ PM & INEEL IRC Lab tour/Geocentrifuge & INEEL/U of I \\
\hline $6: 00-8: 00 \mathrm{PM}$ & Dinner & Jakers Restaurant (Lindsay Ave) \\
\hline \multicolumn{3}{|c|}{ Day 3 -Wednesday, August 25} \\
\hline Time & Topic & Presenters \\
\hline $8: 00-8: 45$ AM & Progress Reports (Carbon trading) & Ted Dodge, NCOC \\
\hline $8: 45-9: 30$ AM & Progress Reports (Public Outreach) & Pam Tomski, EnTech Strategies \\
\hline $9: 30-11: 00 \mathrm{AM}$ & Progress Reports (Terrestrial) & MSU, SDSMT, Texas A\&M \\
\hline $11: 00-12: 00$ & Progress Reports (Regulatory Compliance) & MSU, LANL \\
\hline 12:00-1:00 PM & Working Lunch & \\
\hline 1:00-2:00 PM & Phase 1 Action Item review & all \\
\hline $2: 00-3: 00 \mathrm{PM}$ & Fossil Energy at INEEL (H2, CO2, etc.) & Bruce Reynolds, INEEL FE Dept. \\
\hline 3:00-5:30 PM & $\begin{array}{l}\text { Partnership Advisory Committee/Partnership } \\
\text { Housekeeping/SSI Presentations }\end{array}$ & INEEL/U of I \\
\hline $6: 00-8: 00 \mathrm{PM}$ & Dinner & Sandpiper Restaurant (Lindsay) \\
\hline \multicolumn{3}{|c|}{ Day 3 -Thursday, August 26} \\
\hline Time & Topic & Presenters \\
\hline $8: 00-9: 30 \mathrm{AM}$ & Discussions with Phase 2 participants & Wyoming, Idaho, others \\
\hline $9: 30 \mathrm{AM}-11: 30$ & Phase 2 Planning & All Phase 2 participants \\
\hline 11:30 AM - 12:00 & Media Interviews & John, Susan, others.. \\
\hline $12: 00-1: 00 \mathrm{PM}$ & Working Lunch & \\
\hline $1: 00-5: 00 \mathrm{PM}$ & $\begin{array}{l}\text { ASME Carbon Sequestration Symposium } \\
\text { held at the University Place Auditorium }\end{array}$ & $\begin{array}{l}\text { Invited speakers, hosted by ASME } \\
\text { (Separate agenda) }\end{array}$ \\
\hline
\end{tabular}

Additional details:

1. Local Idaho Falls map with CHE and building location, airport, and hotel locations in local area. 


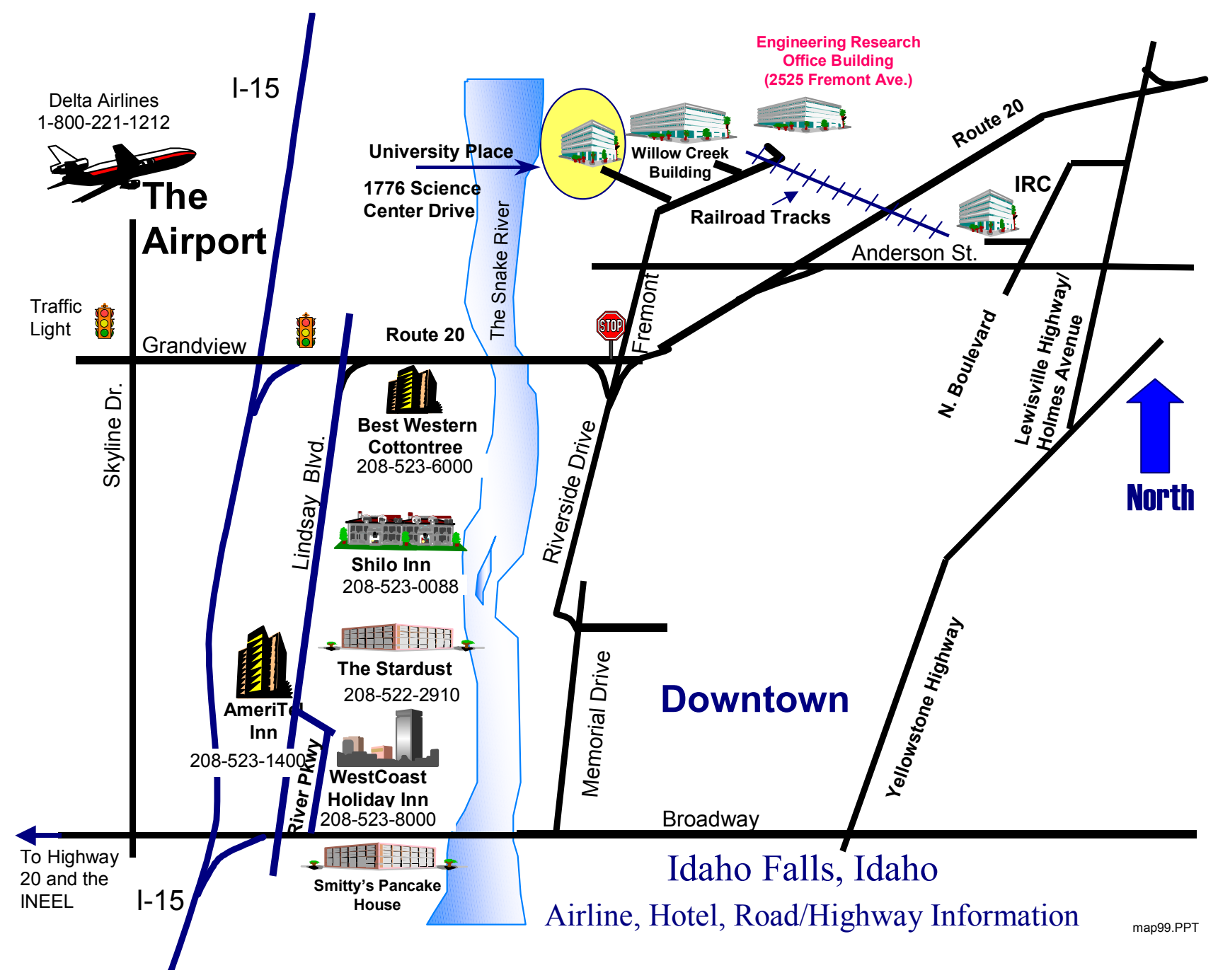


The American Society of Mechanical Engineers (ASME) Presents:

The Carbon Sequestration Symposium

\author{
August 26, 2004 \\ 1:00 pm to 5:00 pm \\ University Place Auditorium \\ 1776 Science Center Drive \\ Idaho Falls ID
}

ASME Moderators: Karen Moore and David Shropshire

Introduction and Welcome by the Department of Energy

Invited Carbon Sequestration Speakers

Anhar Karimjee, EPA's Carbon Sequestration effort John Litynski (DOE), Carbon Sequestration Program

Susan Capalbo (MSU), Big Sky Partnership

Ross Bricklemyer (MSU), Terrestrial Sequestration

Robert Smith (U of I), Geologic Sequestration

Pamela Tomski (EnTech Strategies), Carbon Capture

\title{
Panel Discussion for Big Sky Region
}

David Ferguson (David Shropshire representing), Idaho Carbon Sequestration Advisory Committee

George Vance, Wyoming Governor's Committee on Carbon Sequestration

Mark Lindberg, Montana Governor's Office

Pat Zimmerman (Pam Tomski representing), South Dakota School of Mines \& Technology

Ted Dodge, Indian Nation perspectives on carbon sequestration

No registration fee required 


\section{SUPPLEMENTAL REQUEST:}

\section{BIG SKY REGIONAL CARBON SEQUESTRATION PARTNERSHIP DE-PS26-O3NT41995 \\ DE-FC26-O3NT41995}

\section{Rationale:}

Our supplemental request for additional funding is primarily to engage in GIS data analysis and research that will allow for coverage to Wyoming, both in terms of evaluation of geological and terrestrial sinks/sources and to build a more inclusive GISbased data inventory for all sources and sinks in the Northern Rockies area. Wyoming would be brought into the Partnership through the Wyoming Governor's Carbon Sequestration Task Group, the University of Wyoming and other industry and government contacts.

More specifically we would:

(a) The Big Sky Carbon Sequestration Partnership is using a two-phased approach for the assessment of regional geologic carbon dioxide sinks. The first phase is the identification of geologic "plays" 1 and then they are screened against carbon dioxide injectability and capacity criteria. The screening eliminates plays that do meet minimum criteria. The remaining plays will be subjected to a detailed analysis to evaluate (using numerical hydrogeochemical modeling) their carbon dioxide trapping potential. In addition, an economic and regulatory feasibility analysis will be conducted. The results of the screening and analysis will be incorporated into a GIS database.

The inclusion of Wyoming in the Big Sky partnership region would almost triple the number of plays (111 vs. 40) that will be evaluated. The geologic $\mathrm{CO}_{2}$ sink screening approach is being developed with current funding, but new funds are needed to support the geologic and regulatory analysis for the additional 71 plays in Wyoming.

(b) On the terrestrial side, the Big Sky partnership is examining both technical and economic feasibility. Currently, there are extensive land areas in Wyoming that are either in rangeland or cropland of some sort. These lands have the potential

\footnotetext{
${ }^{1}$ The fundamental geologic unit used in the 1995 National Oil and Gas Assessment was the 'play', which is defined as a set of known or postulated oil and or gas accumulations sharing similar geologic, geographic, and temporal properties, such as source rock, migration pathways, timing, trapping mechanism, and hydrocarbon type.
} 
for terrestrial sequestration with perhaps minimal changes in land use/management options. Given the vast acreage involved, terrestrial sequestration could provide a win-win situation for producers and government or private carbon buyers. We would propose to expand the coverage of terrestrial sinks/sources to include Wyoming. The data and analysis would be incorporated into the GIS database. Eventually we would use this information from Wyoming to select some demonstration sites for measuring and monitoring carbon storage on rangeland.

\section{Scope of Work:}

The Partnership's objectives are: (i) identify and catalogue sources of $\mathrm{CO}_{2}$ and promising geologic and terrestrial storage sites; (ii) develop a risk assessment and decision support framework to optimize the region's carbon storage portfolio; (iii) enhance market-based, voluntary approaches to carbon storage; (iv) identify and apply advanced GHG measurement technologies to improve verification protocols, support voluntary trading and stimulate economic development; (v) engage community leaders to define carbon sequestration implementation strategies and (vi) create forums to inform and secure input from the public. The project has four phases: geologic sequestration, terrestrial sequestration, advanced concepts, and outreach. The Big Sky Regional Carbon Sequestration Partnership initially consisted of the states of Montana, Idaho, and South Dakota. This supplemental request would provide the resources to expand the coverage of the partnership to include Wyoming.

\section{Tasks under the Supplemental Proposal:}

The supplemental proposal would modify the following Tasks to include coverage for Wyoming:

\section{Task 1 - Regional GHG Source and Geologic Sequestration Characterization}

\section{Task 1.1 - Source Characterization}

The project will survey both industrial and agricultural GHG $\left(\mathrm{CO}_{2}, \mathrm{CH}_{4}\right.$ and $\left.\mathrm{N}_{2} \mathrm{O}\right)$ sources within three major categories: (1) fossil fuel power plants; (2) industrial plants including metals manufacturing, chemical processing and ethanol production and (3) agricultural sources (principally feedlots). Emissions will be estimated using standard guidelines and emissions factors recommended by EPA's Emission Inventory Improvement Program (EIIP Document Series Vol. VIII, Estimating Greenhouse Gas Emissions) [2], supplemented with information from the Revised 1996 IPCC Guidelines for National Greenhouse Gas Inventories, Reference Manual, and the Good Practice 
Guidance and Uncertainty Management in National Greenhouse Gas Inventories [3]. Source data will be collected from cooperating state agencies and from national databases (EPA E-Grid, NEI facility data, DOE-EIA state energy data). Industrial facility and utility information will be derived where possible from air-quality permit data assembled by the respective state air quality agencies. Livestock inventories will be collected from the NASS county-level farm census data (through 2001) for each state. Other approaches for estimating GHG emissions may be used depending on the availability and quality of our sources of information.

\section{Task 1.2 - Geological Sequestration Characterization}

Evaluate the geologic sequestration potential of sedimentary and volcanic basins the region, which includes Idaho, Montana, South Dakota, Wyoming, and geologically contiguous areas in North Dakota. At a minimum, the following geologic formations will be assessed: deep saline aquifers, depleted oil/gas reservoirs, deep unmineable coal beds, and mafic/ultramafic rocks. Available characterization data will be issued to evaluate the potential for each formation to serve as a $\mathrm{CO}_{2}$ sequestration reservoir against the following criteria: potential for hydrodynamic trapping; potential for solubility trapping; potential for mineralization trapping; technical feasibility and time frame for implication and offsetting economic benefits. Compilation of geologic data: e.g. prevalent geology, porosity, formation thickness, extent of formations. Coal properties such as coal rank, average pore-size distribution, surface area will be collected for coalbed methane reservoirs. Determination of storage capacity for oil/gas reservoirs, storage capacity would be evaluated in terms of volumetric capacities as well as capacity. For aquifers, the storage capacity would be mainly determined from solubility in water/brine. For coalbed methanes, storage capacity would be evaluated in terms of volumetric capacity as well as capacity resulting from displacement of methane by $\mathrm{CO}_{2}$. Determination of long-term storage capability: Geologic and geophysical information would be carefully analyzed to determine whether adequate geologic barriers exist to trap $\mathrm{CO}_{2}$ long term. The evaluation will result in each formations classification of either: 1) favorable and worthy of further consideration; 2) unfavorable; or 3) insufficient information to classify, unless a different ranking scheme is determined more appropriate during the project.

\section{Task 2 - Infrastructure Characterization}

Existing and infrastructure requirements will be evaluated within the region.

Transportation information such as pipeline and rail infrastructure will be derived from siting boards and transportation departments, or other relevant information. In addition, assess the maturity of sequestration technologies and the availability of the necessary infrastructure for implementation. All the relevant infrastructure information for each sink would be evaluated and included in the database and GIS under Task 3. This will include number of active wells, surface facilities required for storage and processing of $\mathrm{CO}_{2}$ as well as produced oil/gas/water, $\mathrm{CO}_{2}$ pipeline and other transportation availability, proximity to major sources. Costs associated with developing the infrastructure necessary for large-scale sequestration would be determined. Technological and economical issues related to separation/capture and transportation of $\mathrm{CO}_{2}$ would be identified and evaluated. 


\section{Task 3 - Incorporate Geologic, Infrastructure, and GHG Source Data into GIS}

The results of the geologic sequestration, infrastructure, and GHG source characterization assessments will be embodied in a geospatial database that is integrated with the terrestrial sequestration assessment.

\section{Task 4 - Data Collection and Literature Review for Terrestrial Sequestration}

Conduct a literature review and collect data on terrestrial sequestration potentials in the region. The type of land uses the data will be collected for, at a minimum, will include croplands, grazing lands, and agroforestry, on private and public lands. Collection and preparation of forest inventory, growth and yield plots, biomass and productivity data and collection of soil data if necessary for the Partnership region. Collection of climate and disturbance data (such as fire, land use, harvesting). Other information may be collected depending on requirements to estimate terrestrial sequestration potential.

\section{Task 5 - Evaluate all Terrestrial Sinks for GHG Emissions in Regional Ecosystems, Identify Infrastructure Requirements, and Prepare as Information Reports}

Compilation of data analysis and management will be conducted. Integration of all possible data from Task 4 and derived during Task 5 into GIS map format. Preparation of TRIPLEX input data.

Task 6 - Overlay the Technical Terrestrial Sequestration Potential With Assessment of Opportunity Costs and Net Economic Benefits

Estimate carbon stocks and fluxes in the Partnership region including Wyoming. Perform comparative projective analysis under different assumed forest management practices, agricultural policies, as well as changing climate scenarios.

\section{TimeLine and Deliverables:}

(Assuming a start date of 10/1/04; end date of 9/30/05)

The deliverables for the supplemental will modify the relevant deliverables in the initial grant that pertain to the above tasks, expanded to include the coverage for Wyoming. These are as follows with the due dates reflecting the modifications to include Wyoming:

Deliverable 1 will reflect the inclusion of Wyoming in all reports stating with first quarter of the second year; deliverable 2 will be update to include Wyoming partners; deliverable 3 will reflect the expanded coverage to WY. 
Geological Sources and Sinks:

Deliverable 4. Report on Infrastructure Data Compilation and Analysis (original July 04, modified to include Wyoming Jan 05)

Deliverable 5. Report on Technology Needs (original Nov 04, modified to include Wyoming by Mar 05)

Deliverable 6. Report and Action Plan for Geological Sinks (original July 04, modified to include Wyoming by Jan 05 )

Terrestrial Sequestration:

Deliverable 7. Terrestrial Sequestration lit review and report (modified by Nov

Deliverable 8. Terrestrial Sequestration, Action Plan and infrastructure needs (original July 04, modified by Jan 05)

Deliverable 9. Carbon Budgets and GIS database for terrestrial sinks (original Sept 04 , modified by Mar 05)

Deliverable 11. Report on evaluation of terrestrial Sinks (original June 05, modification to include Wyoming on approximately the same time frame)

\section{Responsibilities:}

The GIS overall responsibility will be at LANL (Paul Rich), the terrestrial component at MSU (Susan Capalbo) and the geological component at INEEL ( Randy Lee, david Shropshire). Susan Capalbo, PI for the Big Sky Partnership, will also oversee the management of the supplement, the travel/coordination with the Wyoming partners and entities, and the inclusion of Wyoming partners in all future meetings and workshops. 
Big Sky Regional Carbon Sequestration Partnership website - www.bigskyco2.org

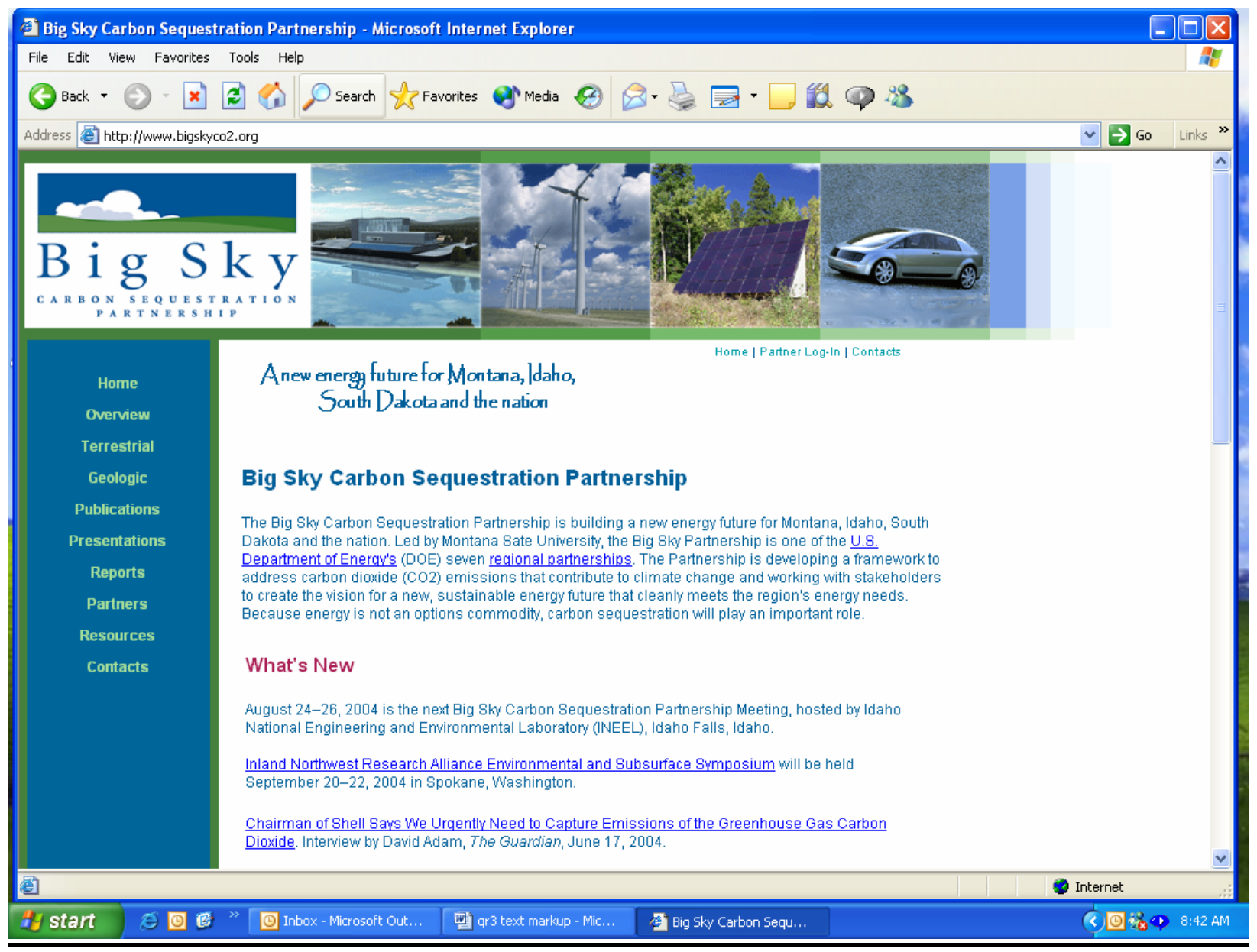




\section{Terrestrial GIS Data 1}

\begin{tabular}{|c|c|c|c|}
\hline Theme & Data set(s) & Description & Originator \\
\hline agricultural & id_dairies & Dairies in Idaho & $\begin{array}{l}\text { ID State Depts of Ag and Env. } \\
\text { Qual. }\end{array}$ \\
\hline civilian/political & id_all_cities & Towns and cities in Idaho & ID Dept. of Water Resources \\
\hline civilian/political & id_townships_100k & Township and range lines for ID & ID Dept. of Water Resources \\
\hline civilian/political & mt_townships_100k & Township and range lines for MT & Montana State Library \\
\hline civilian/political & us_counties_100k & $\begin{array}{l}\text { Detailed county boundaries consistent with tract and state } \\
\text { data sets }\end{array}$ & ESRI \\
\hline civilian/political & us_counties_gen & Generalized county boundaries & ESRI \\
\hline civilian/political & us_states_100k & $\begin{array}{l}\text { Detailed state boundaries consistent with tract and state } \\
\text { data sets }\end{array}$ & ESRI \\
\hline civilian/political & us_states_gen & Generalized state boundaries & ESRI \\
\hline climate & $\begin{array}{l}\text { id_ave_ann_precip_ } \\
\text { pol }\end{array}$ & ID average annual precipitation, 1961-90 & Oregon State University \\
\hline climate & mt_ave_ann_precip_ & MT average annual precipitation, 1961-90 & Oregon State University \\
\hline climate & $\underset{\text { pol }}{\text { mt_ave_ann_precip_ }}$ & MT average annual precipitation, 1961-90 & Oregon State University \\
\hline climate & us_clim_divs & Climate Divisions in the US & \\
\hline climate & us_coop_sta & Cooperative weather stations in the US & \\
\hline
\end{tabular}




\section{Terrestrial GIS Data 2}

\begin{tabular}{|l|l|l|l|}
\hline Theme & Data set(s) & Description & Originator \\
\hline demographic & id_pop & Population of U.S. Census block centroids for Idaho & ESRI \\
\hline demographic & id_urban_2000 & Urbanized areas in Idaho, 2000 & $\begin{array}{l}\text { US Dept. of Commerce Bureau of } \\
\text { Census }\end{array}$ \\
\hline demographic & mt_pop & Population of U.S. Census block centroids for Montana & ESRI \\
\hline demographic & mt_popden2000 & MT 2000 population density & Montana State Library \\
\hline demographic & sd_pop & Population of U.S. Census block centroids for South Dakota & ESRI \\
\hline demographic & us_cities & $\begin{array}{l}\text { Cities within U.S. with population of 10,000 or greater and } \\
\text { state capitals }\end{array}$ & ESRI \\
\hline demographic & us_msa & Metropolitan statistical areas & Geographic Data Technology, Inc. \\
\hline demographic & us_urban & $\begin{array}{l}\text { Boundaries for urban areas with a population greater than } \\
50,000\end{array}$ & Bureau of Transportation Statistics, \\
\hline environmental & mt_fire_2000 & Perimiters of Year 2000 fires, MT & Montana State Library \\
\hline environmental & mtarea_fire_2003 & $\begin{array}{l}\text { Perimiters of Year 2003 fires, US Forest Service Northern } \\
\text { Region }\end{array}$ & $\begin{array}{l}\text { Northern Rockies Coordinating } \\
\text { Group }\end{array}$ \\
\hline
\end{tabular}




\section{Terrestrial GIS Data 3}

\begin{tabular}{|c|c|c|c|}
\hline Theme & Data set(s) & Description & Originator \\
\hline Hydrologic & id_dams & Dams in Idaho & Sonny Hornbaker \\
\hline Hydrologic & id_lakes_100k & Lakes in Idaho & Linda Davis, Sandra Thiel \\
\hline hydrologic & id_rivers & Streams and rivers in Idaho & $\begin{array}{l}\text { Geographic Data Technology, Inc., } \\
\text { ESRI }\end{array}$ \\
\hline hydrologic & id_streams_100k & Streams and rivers in Idaho at $1: 100 \mathrm{k}$ & Linda Davis, Sandra Thiel \\
\hline hydrologic & id_wetlands & Wetlands in Idaho & Landscape Dynamics Lab \\
\hline hydrologic & mt_dams & Dams in Montana & MT Fish, Wildlife and Parks \\
\hline hydrologic & mt_lakes_100k & $\begin{array}{l}\text { Streams and lakes in MT from 1:100k US Census Bureau } \\
\text { TIGER files }\end{array}$ & Montana State Library \\
\hline hydrologic & mt_rivers & Streams and rivers in Montana & $\begin{array}{l}\text { Geographic Data Technology, Inc., } \\
\text { ESRI }\end{array}$ \\
\hline hydrologic & mt_streams_100k & $\begin{array}{l}\text { Streams and lake shorelines from 1:100k US Census } \\
\text { Bureau TIGER files }\end{array}$ & Montana State Library \\
\hline hydrologic & sd_rivers & Streams and rivers in South Dakota & $\begin{array}{l}\text { Geographic Data Technology, Inc., } \\
\text { ESRI }\end{array}$ \\
\hline hydrologic & us_hydropoly & Water feature areas (bays, glaciers, lakes, and swamps) & National Atlas and USGS, ESRI \\
\hline
\end{tabular}




\section{Terrestrial GIS Data 4}

\begin{tabular}{|c|c|c|c|}
\hline Theme & Data set(s) & Description & Originator \\
\hline Hydrologic & id_dams & Dams in Idaho & Sonny Hornbaker \\
\hline Hydrologic & id_lakes_100k & Lakes in Idaho & Linda Davis, Sandra Thiel \\
\hline hydrologic & id_rivers & Streams and rivers in Idaho & $\begin{array}{l}\text { Geographic Data Technology, Inc., } \\
\text { ESRI }\end{array}$ \\
\hline hydrologic & id_streams_100k & Streams and rivers in Idaho at $1: 100 \mathrm{k}$ & Linda Davis, Sandra Thiel \\
\hline hydrologic & id_wetlands & Wetlands in Idaho & Landscape Dynamics Lab \\
\hline hydrologic & mt_dams & Dams in Montana & MT Fish, Wildlife and Parks \\
\hline hydrologic & mt_lakes_100k & $\begin{array}{l}\text { Streams and lakes in MT from 1:100k US Census Bureau } \\
\text { TIGER files }\end{array}$ & Montana State Library \\
\hline hydrologic & mt_rivers & Streams and rivers in Montana & $\begin{array}{l}\text { Geographic Data Technology, Inc., } \\
\text { ESRI }\end{array}$ \\
\hline hydrologic & mt_streams_100k & $\begin{array}{l}\text { Streams and lake shorelines from 1:100k US Census } \\
\text { Bureau TIGER files }\end{array}$ & Montana State Library \\
\hline hydrologic & sd_rivers & Streams and rivers in South Dakota & $\begin{array}{l}\text { Geographic Data Technology, Inc., } \\
\text { ESRI }\end{array}$ \\
\hline hydrologic & us_hydropoly & Water feature areas (bays, glaciers, lakes, and swamps) & National Atlas and USGS, ESRI \\
\hline
\end{tabular}




\section{Terrestrial GIS Data 5}

\begin{tabular}{|c|c|c|c|}
\hline Theme & Data set(s) & Description & Originator \\
\hline $\begin{array}{l}\text { Land } \\
\text { management }\end{array}$ & $\begin{array}{l}\text { ID, MT, SD tillage } \\
\text { practices }\end{array}$ & $\begin{array}{l}\text { Acreage data from the Conservation Technology } \\
\text { Information Center (CTIC) by county and general crop type } \\
\text { on tillage methods used in ID. MT, and SD }\end{array}$ & $\begin{array}{l}\text { Conservation Technology } \\
\text { Information Center }\end{array}$ \\
\hline $\begin{array}{l}\text { Land } \\
\text { management }\end{array}$ & $\begin{array}{l}\text { id_land_managemen } \\
\mathrm{t}\end{array}$ & Special land management areas in Idaho & ID Dept. of Water Resources \\
\hline $\begin{array}{l}\text { Land } \\
\text { management }\end{array}$ & id_land_ownership & Surface land ownership in Idaho & ID Dept. of Water Resources \\
\hline $\begin{array}{l}\text { Land } \\
\text { management }\end{array}$ & id_nat_forests & National forests in Idaho & $\begin{array}{l}\text { Interior Columbia Basin Eco. Mngt. } \\
\text { Project }\end{array}$ \\
\hline $\begin{array}{l}\text { Land } \\
\text { management }\end{array}$ & mt_fwplands & Montana Fish, Wildlife and Parks managed land & MT FWP and MT State Library \\
\hline $\begin{array}{l}\text { Land } \\
\text { management }\end{array}$ & mt_indian_res & Montana Indian reservations & Montana State Library \\
\hline $\begin{array}{l}\text { Land } \\
\text { management }\end{array}$ & mt_land_stewardshi & Land ownership and manages areas in Montana & Montana Natural Heritage Program \\
\hline $\begin{array}{l}\text { Land } \\
\text { management }\end{array}$ & mt_nat_forests & National forests and ranger districts in Montana & Montana Natural Heritage Program \\
\hline $\begin{array}{l}\text { Land } \\
\text { management }\end{array}$ & mt_nps & National Park Service units in Montana & Montana Natural Heritage Program \\
\hline $\begin{array}{l}\text { Land } \\
\text { management }\end{array}$ & mt_nwr & National Wildlife Refuges in Montana & Montana Natural Heritage Program \\
\hline $\begin{array}{l}\text { Land } \\
\text { management }\end{array}$ & $\begin{array}{l}\text { mt_wilderness_area } \\
\text { s }\end{array}$ & Designated Wildernes Areas in Montana & Montana Natural Heritage Program \\
\hline $\begin{array}{l}\text { Land } \\
\text { management }\end{array}$ & us_fedland & Federal and Indian-owned land areas & National Atlas and USGS, ESRI \\
\hline $\begin{array}{l}\text { Land } \\
\text { management }\end{array}$ & us_parks & $\begin{array}{l}\text { National Parks, National Forests, State and local parks and } \\
\text { forests }\end{array}$ & $\begin{array}{l}\text { ESRI, Geographic Data } \\
\text { Technology, Ing }\end{array}$ \\
\hline
\end{tabular}




\section{Terrestrial GIS Data 6}

\begin{tabular}{|c|c|c|c|}
\hline Theme & Data set(s) & Description & Originator \\
\hline soils & ID county soils & $\begin{array}{l}\text { Rasters of bulk density, clay percent, sand percent, and silt } \\
\text { percent for each county in ID. For each county, SSURGO } \\
\text { data are used where it is present. STATSGO data are used } \\
\text { in areas where SSURGO data are not present }\end{array}$ & SDSMT \\
\hline soils & id_statsgo & State soil geographic (STATSGO) data base for Idaho & USDA, NRCS \\
\hline soils & id11buin & $\begin{array}{l}\text { Raster of bulk density integer values corresponding to } \\
\text { STATSGO map units }\end{array}$ & SDSMT \\
\hline soils & id11clin & $\begin{array}{l}\text { Raster of clay percent integer values corresponding to } \\
\text { STATSGO map units }\end{array}$ & SDSMT \\
\hline soils & id11sain & $\begin{array}{l}\text { Raster of sand percent integer values corresponding to } \\
\text { STATSGO map units }\end{array}$ & SDSMT \\
\hline soils & id11siin & $\begin{array}{l}\text { Raster of silt percent integer values corresponding to } \\
\text { STATSGO map units }\end{array}$ & SDSMT \\
\hline soils & id12buin & $\begin{array}{l}\text { Raster of bulk density integer values corresponding to } \\
\text { STATSGO map units }\end{array}$ & SDSMT \\
\hline soils & id12clin & $\begin{array}{l}\text { Raster of clay percent integer values corresponding to } \\
\text { STATSGO map units }\end{array}$ & SDSMT \\
\hline soils & id12sain & $\begin{array}{l}\text { Raster of sand percent integer values corresponding to } \\
\text { STATSGO map units }\end{array}$ & SDSMT \\
\hline soils & id12siin & $\begin{array}{l}\text { Raster of silt percent integer values corresponding to } \\
\text { STATSGO map units }\end{array}$ & SDSMT \\
\hline soils & MT county soils & $\begin{array}{l}\text { Rasters of bulk density, clay percent, sand percent, and silt } \\
\text { percent for each county in MT. For each county, SSURGO } \\
\text { data are used where it is present. STATSGO data are used } \\
\text { in areas where SSURGO data are not present }\end{array}$ & SDSMT \\
\hline soils & mt_statsgo & State soil geographic (STATSGO) data base for Montana & USDA, NRCS \\
\hline soils & mt11buin & $\begin{array}{l}\text { Raster of bulk density integer values corresponding to } \\
\text { STATSGO map units }\end{array}$ & SDSMT \\
\hline
\end{tabular}




\section{Terrestrial GIS Data 7}

\begin{tabular}{|l|l|l|l|}
\hline Theme & Data set(s) & Description & Originator \\
\hline soils & Mt11clin & $\begin{array}{l}\text { Raster of clay percent integer values corresponding to } \\
\text { STATSGO map units }\end{array}$ & SDSMT \\
\hline soils & mt11sain & $\begin{array}{l}\text { Raster of sand percent integer values corresponding to } \\
\text { STATSGO map units }\end{array}$ & SDSMT \\
\hline soils & mt11sin & $\begin{array}{l}\text { Raster of silt percent integer values corresponding to } \\
\text { STATSGO map units }\end{array}$ & SDSMT \\
\hline soils & mt12buin & $\begin{array}{l}\text { Raster of bulk density integer values corresponding to } \\
\text { STATSGO map units }\end{array}$ & SDSMT \\
\hline soils & mt12clin & $\begin{array}{l}\text { Raster of clay percent integer values corresponding to } \\
\text { STATSGO map units }\end{array}$ & SDSMT \\
\hline soils & mt12sain & $\begin{array}{l}\text { Raster of sand percent integer values corresponding to } \\
\text { STATSGO map units }\end{array}$ & SDSMT \\
\hline soils & mt12siin & $\begin{array}{l}\text { Raster of silt percent integer values corresponding to } \\
\text { STATSGO map units }\end{array}$ & SDSMT \\
\hline soils & mt13buin & $\begin{array}{l}\text { Raster of bulk density integer values corresponding to } \\
\text { STATSGO map units }\end{array}$ & SDSMT \\
\hline soils & mt13clin & $\begin{array}{l}\text { Raster of clay percent integer values corresponding to } \\
\text { STATSGO map units }\end{array}$ & SDSMT \\
\hline soils & mt13sain & $\begin{array}{l}\text { Raster of sand percent integer values corresponding to } \\
\text { STATSGO map units }\end{array}$ & SDSMT \\
\hline soils & mt13siin & $\begin{array}{l}\text { Raster of silt percent integer values corresponding to } \\
\text { STATSGO map units }\end{array}$ & SDSMT \\
\hline \multirow{2}{*}{ soils } & SD county soils & $\begin{array}{l}\text { Rasters of bulk density, clay percent, sand percent, and silt } \\
\text { percent for each county in SD. For each county, SSURGO } \\
\text { data are used where it is present. STATSGO data are used } \\
\text { in areas where SSURGO data are not present }\end{array}$ & SDSMT \\
\hline soils & $\begin{array}{l}\text { State soil geographic (STATSGO) data base for South } \\
\text { Dakota }\end{array}$ & USDA, NRC5 \\
\hline \hline
\end{tabular}




\section{Terrestrial GIS Data 8}

\begin{tabular}{|c|c|c|c|}
\hline Theme & Data set(s) & Description & Originator \\
\hline transportation & id_majroads & $\begin{array}{l}\text { Interstate, U.S. and state highways, and other major roads } \\
\text { in Idaho }\end{array}$ & $\begin{array}{l}\text { Geographic Data Technology, Inc., } \\
\text { ESRI }\end{array}$ \\
\hline transportation & mt_majroads & $\begin{array}{l}\text { Interstate, U.S. and state highways, and other major roads } \\
\text { in Montana }\end{array}$ & $\begin{array}{l}\text { Geographic Data Technology, Inc., } \\
\text { ESRI }\end{array}$ \\
\hline transportation & mt_rail_100k & Montana railroads from the National Rail Network $1: 100 \mathrm{k}$ & $\begin{array}{l}\text { Fed. Railroad Admin., Bur. of Tran. } \\
\text { Stat. }\end{array}$ \\
\hline transportation & sd_majroads & $\begin{array}{l}\text { Interstate, U.S. and state highways, and other major roads } \\
\text { in South Dakota }\end{array}$ & $\begin{array}{l}\text { Geographic Data Technology, Inc., } \\
\text { ESRI }\end{array}$ \\
\hline Added by KLU: & & & \\
\hline emissions & 99neiv2asciiarea & 1999 nationwide NEI (criteria and HAP) pollutant data & SDSMT \\
\hline emissions & eGRID2002yr00 & $\begin{array}{l}2000 \text { nationwide CO2 emissions from utilities/energy } \\
\text { producers }\end{array}$ & SDSMT \\
\hline emissions & bysector_id & $\begin{array}{l}2001 \text { emissions of } \mathrm{CO} 2, \mathrm{CH} 4 \text { and } \mathrm{N} 2 \mathrm{O} \text { from energy } \\
\text { production/use }\end{array}$ & SDSMT \\
\hline emissions & bysector_mt & $\begin{array}{l}2001 \text { emissions of } \mathrm{CO} 2, \mathrm{CH} 4 \text { and } \mathrm{N} 2 \mathrm{O} \text { from energy } \\
\text { production/use }\end{array}$ & SDSMT \\
\hline emissions & bysector_sd & $\begin{array}{l}2001 \text { emissions of } \mathrm{CO} 2, \mathrm{CH} 4 \text { and } \mathrm{N} 2 \mathrm{O} \text { from energy } \\
\text { production/use }\end{array}$ & SDSMT \\
\hline forestry & $\begin{array}{l}\text { TablesForStateTotal } \\
\mathrm{s}\end{array}$ & Data from GTRNE 298; forest C stocks/fluxes as of 19997 & SDSMT \\
\hline emissions & livestock & $\begin{array}{l}1997 \text { cattle, hog, poultry, sheep, horse etc.. inventory data } \\
\text { from Ag Census }\end{array}$ & SDSMT \\
\hline
\end{tabular}




\section{Geologic Carbon Sequestration GIS Database Structure and Summary of Infrastructure Data Compilation and Analysis Inputs}

The Idaho National Engineering and Environmental Laboratory (INEEL) is supporting the Big Sky Partnership by providing geologic carbon sequestration evaluations and geospatial data management. The region of interest includes Idaho, Montana, South Dakota, and geologically contiguous areas in North Dakota and Wyoming. The geologic sequestration potential is being assessed in sedimentary and volcanic basins including deep saline aquifers, depleted oil/gas reservoirs, deep unminable coal beds, and mafic/rock hosted fresh aquifers. During this first year of a two-year program, the INEEL Geologic Sequestration team has developed a Geographical Information System (GIS) database structure and identified the sources of data that will be populated in the database. During the next year, these data will be evaluated to determine the sequestration potential for geologic sites within the Big Sky region.

The INEEL is assessing the sequestration potential of the large traditional hydrocarbon basins located in Montana, Wyoming and South Dakota; and additionally has developed a procedure to evaluate the non-traditional volcanic basins plays found in southern Idaho. These non-traditional volcanic basins were first identified and classified by the U.S. Geologic Survey (USGS) in a 1995 report detailing the oil and gas potential of the United States (USGS 1995). These basins contain multiple plays" ${ }^{1}$ within the Eastern and Western Snake River Plains. Because these basins are of volcanic origin, they have not been explored for hydrocarbons and therefore, there is not the wealth of oil patch data available for them like there is for the oil and gas producing basins of Montana and Wyoming. As a result, data will be collected from a diversity of sources including but not limited to wells that have been drilled for geothermal exploration, and outcroppings of primary geologic features. Because the Eastern and Western Snake River Plains are unique volcanic basins, there are a large number of publications available that have described the water chemistry, mineralogy, and structure of the system. The data needed to populate the database will be extracted from the available sources, this process is more labor intensive, but will result in data comparable to the other basins.

During the performance period the overall approach to assess geologic carbon sequestration potential was developed (Figure 1). This assessment is based on the data collected and fed into a GIS based database. The database is structured to feed critical information into the geochemical and reservoir modeling activities. These modeling activities will then be used to characterization the suitability of each candidate site with respect to its carbon dioxide sequestration potential. The modeling approach is detailed in a report by Smith et al 2004 see attached. We are using a two-phased approach for the assessment of regional geologic carbon dioxide sinks found within the study area. The first phase is the identification of geologic 'plays' that are screened against carbon

\footnotetext{
${ }^{1}$ The fundamental geologic unit used in the 1995 National Oil and Gas Assessment was the 'play', which is defined as a set of known or postulated oil and or gas accumulations sharing similar geologic, geographic, and temporal properties, such as source rock, migration pathways, timing, trapping mechanism, and hydrocarbon type
} 
dioxide injectability and capacity criteria. The screening eliminates plays that do not meet minimum criteria. The play determined to be suitable will be subjected to a detailed analysis to evaluate (using numerical hydrogeochemical modeling) their carbon dioxide trapping potential. In addition, an economic and infrastructure feasibility analysis will be conducted. The results of the screening and analysis are now being incorporated into a GIS database.

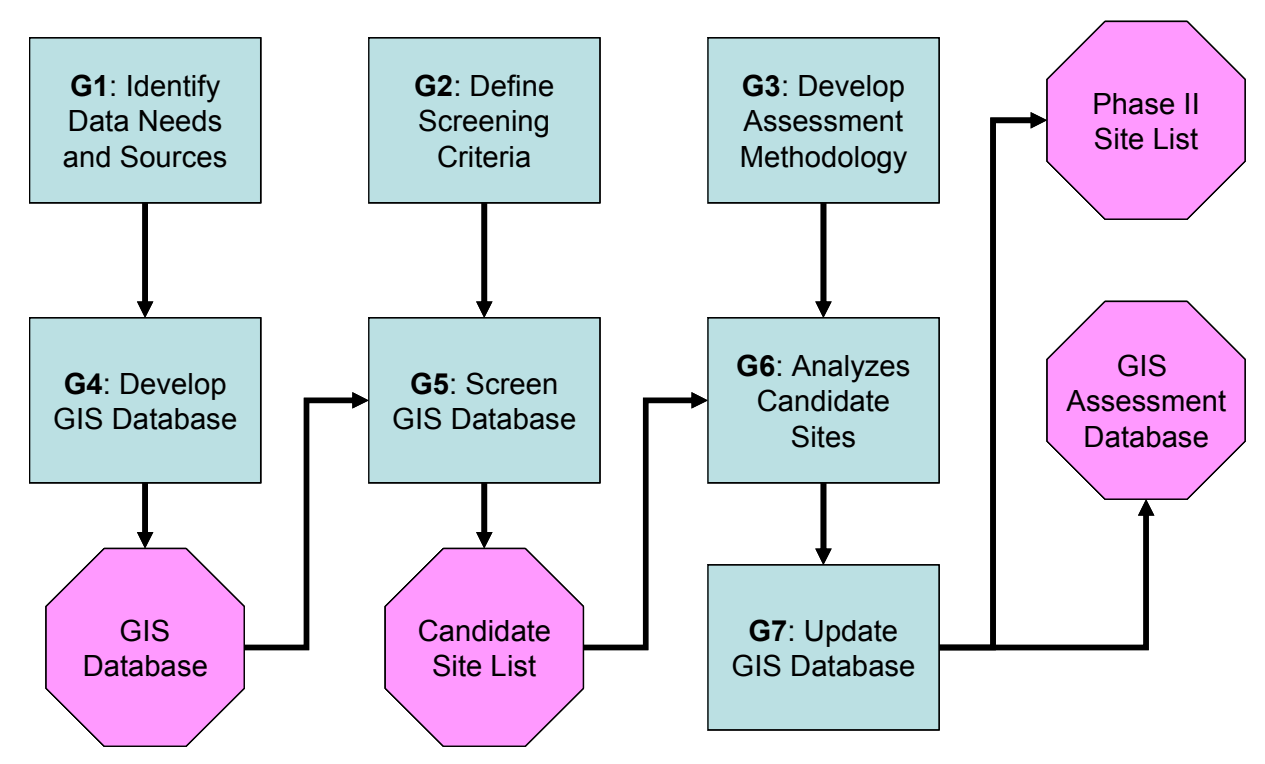

Figure 1 Process to organize the data and model the sequestration potential of each potential site.

Storage and entombment of carbon takes place on or beneath the surface of the earth, therefore, the information associated with carbon sequestration naturally fits into a geographic information system. A GIS is a computer-based tool for mapping and analyzing phenomena that exist and events that occur on and beneath the Earth's surface. GIS technology integrates common database operations such as query and statistical analysis with the unique visualization and geographic analysis benefits offered by maps. A GIS stores information about the world as a collection of thematic layers that can be linked together by geography.

The GIS database has been constructed for all geospatial information - both GIS map layers and data tables - associated with this project including, but not limited to:

- Carbon information (sources and potential sinks)

- Cultural features (roads, cities, counties, etc.)

- Land Use/Land Cover (land ownership, cover type)

- Topography (elevation)

- Hydrography (rivers, streams, lakes) 
The GIS database has been built using Environmental Systems Research Institute (ESRI) products to optimize compatibility across the user base. Geospatial information housed in the GIS complies with the Federal Geographic Data Committee's (FGDC) metadata standards for documenting source and lineage of geospatial data.

Geospatial information associated with geologic sequestration for the Big Sky

Partnership has been and continues to be collected from a variety of sources. These sources include the Wyoming Oil and Gas Conservation Commission, US Geological Survey, Montana Geological Survey, Montana Board of Oil and Gas Conservation, Environmental Systems Research Institute, Wyoming Geographic Information Science Center, Idaho Department of Water Resources, and Montana Natural Resources Information System. All GIS data layers, associated data tables, and metadata have been placed in a directory structure that reflects the type of data one would expect to find by the name of each subdirectory.

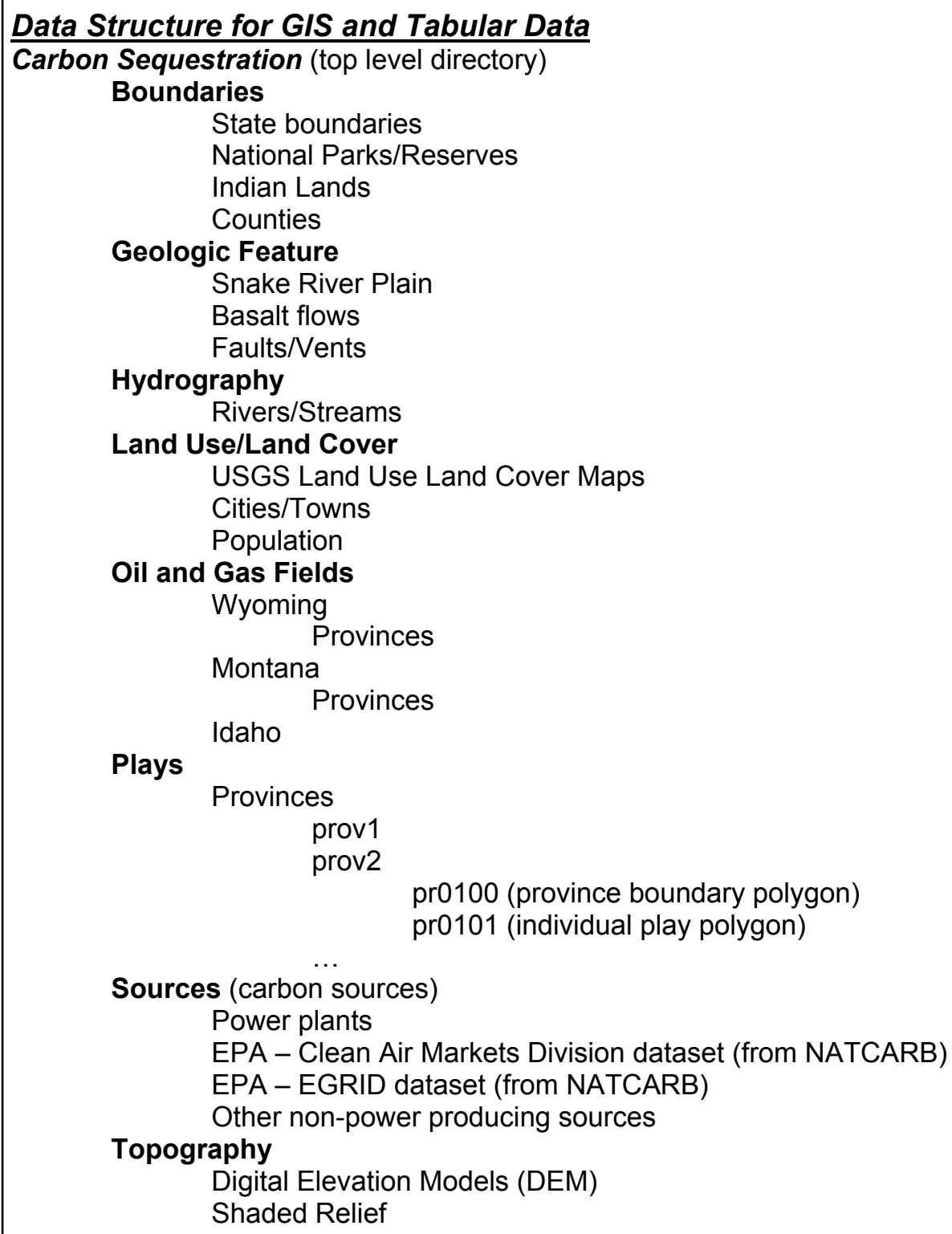




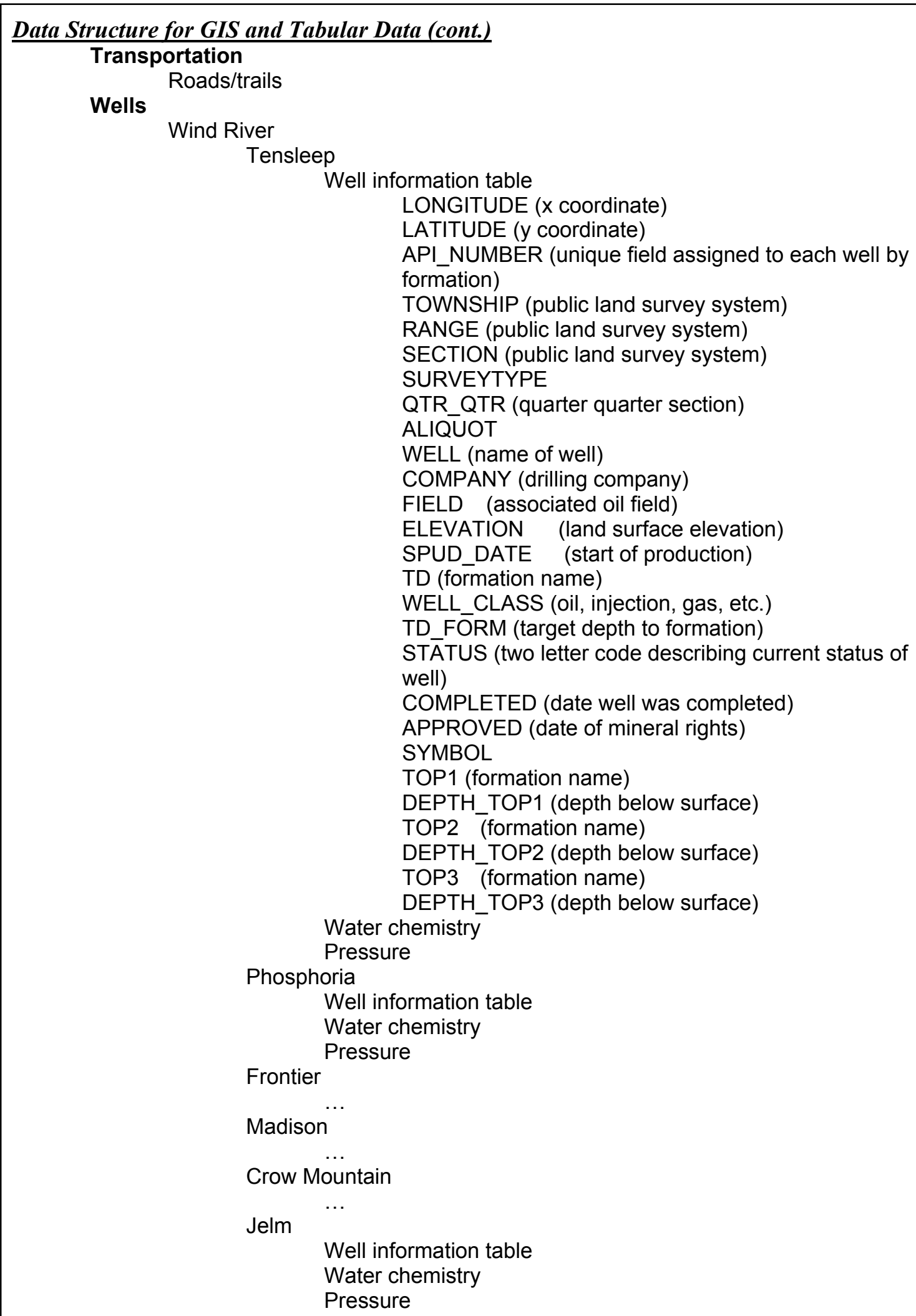


Most of the files that reside in the data structure are already in the form of a GIS layer; however, a number of tables including well information, water chemistry and pressure get linked to the appropriate play by geographic location and a key field called API_Number (see Figure 2).

Information collection to date for wells and geologic features has focused on Wyoming mainly due to the large amount of data available (117,304 active wells). Montana also has adequate well (approximately 50,000 active wells) and oil field information, but Idaho is less rich in oil and gas well data. For Idaho, most well information will come from the USGS, Idaho Department of Water Resources, papers, reports, and books. 

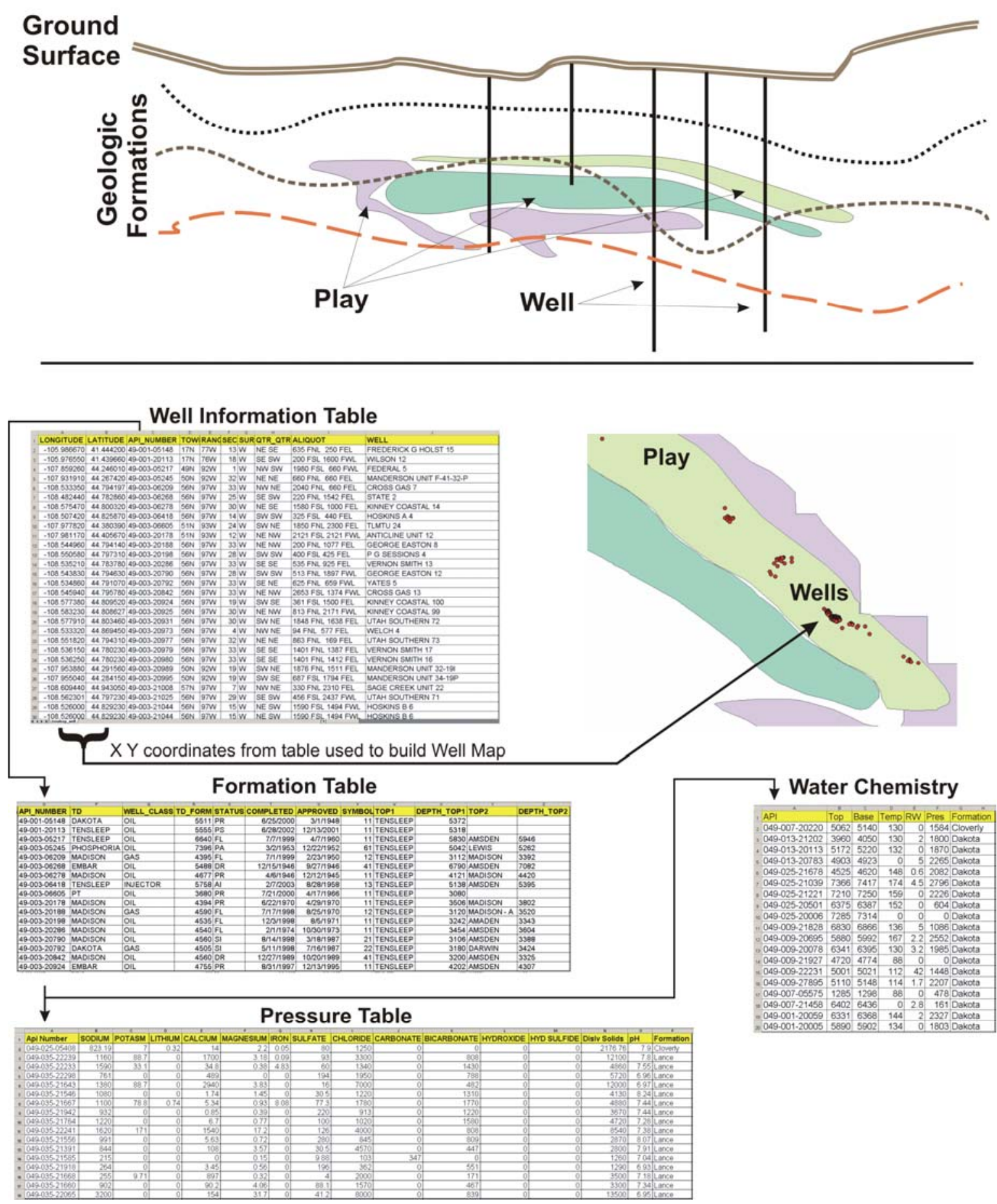

Figure 2 GIS Database Structure for Plays, Wells, and Geologic Formations. 


\section{References:}

1. USGS - multiple authors, 1995, 1995 National Assessment of United States Oil and Gas Resources; U.S. Geological Survey Circular 1118, U.S. Government Printing Office, Washington, 1995.

2. Smith R.W., McLing T.L., Barrash W., Clement W.P., Erickson N.P., Geologic Sequestration of $\mathrm{CO}_{2}$ : A Uniform Strategy for Assessing Mineralization Trapping Potential Across Rock Types, Proceedings of the Third Annual Conference on Carbon Capture and Sequestration, Alexandria, VA, May 2004. 


\section{INRA 2003 Subsurface Science Symposium Agenda}

Sunday, October 5, 2003

\begin{tabular}{|l|l|l|}
\hline 5:30 - 7:30 pm & Registration Desk Open & Salt Palace \\
\hline 6:00 - 8:00 pm & Welcome Reception & $\begin{array}{l}\text { Salt Palace - } \\
\text { Room 251D }\end{array}$ \\
\hline
\end{tabular}

\begin{tabular}{|c|c|c|}
\hline \multicolumn{3}{|c|}{ Monday, October 6, 2003} \\
\hline $7: 30 \mathrm{am}-4: 30 \mathrm{pm}$ & Registration Desk Open & Salt Palace \\
\hline $\begin{array}{c}8: 30-9: 20 \mathrm{am} \\
8: 30 \mathrm{am} \\
\\
8: 35 \mathrm{am} \\
\\
8: 40 \mathrm{am} \\
8: 55 \mathrm{am} \\
\text { 9:10 am }\end{array}$ & $\begin{array}{l}\text { Welcome and Overview } \\
\text { - Welcome \& Symposium Information - Gautam Pillay, Executive } \\
\text { Director, INRA } \\
\text { - Welcome - Kermit Hall, INRA Vice President, Utah State Univ. } \\
\text { President } \\
\text { - INRA Overview - Gautam Pillay, Executive Director, INRA } \\
\text { - INEEL Overview - Paul Kearns, Deputy Director, Idaho National } \\
\text { Engineering and Environmental Laboratory } \\
\text { - DOE-ID Overview - Linda McCoy, Chief Scientist, U.S. } \\
\text { Department of Energy Idaho Operations }\end{array}$ & $\begin{array}{l}\text { Salt Palace - } \\
\text { Room 251D }\end{array}$ \\
\hline $9: 20-9: 30$ am & $\begin{array}{l}\text { Subsurface Science Initiative - P. Michael Wright, Director, } \\
\text { Subsurface Science Initiative, INEEL, "Advancing the Subsurface } \\
\text { Science Research Agenda - A Call to Action" }\end{array}$ & $\begin{array}{l}\text { Salt Palace - } \\
\text { Room 251D }\end{array}$ \\
\hline $9: 30-10: 15$ am & $\begin{array}{l}\text { Keynote Address - Dr. Harrison (Jack) Schmitt, Former New Mexico } \\
\text { Senator and Apollo } 17 \text { Astronaut, "Field Exploration on the Moon" } \\
\text { Click here for Dr. Schmitt's biography. }\end{array}$ & $\begin{array}{l}\text { Salt Palace - } \\
\text { Room 251D }\end{array}$ \\
\hline $10: 15-10: 30$ am & Break, continental breakfast provided & $\begin{array}{l}\text { Salt Palace - } \\
\text { Landing }\end{array}$ \\
\hline $10: 30$ - 11:05 am & $\begin{array}{l}\text { Plenary Address - Dr. Terry Hazen, Lawrence Berkeley National } \\
\text { Laboratory, "Natural Attenuation and Bioremediation: Critical } \\
\text { Biogeochemistry in Treatment Trains" } \\
\text { Click here for Dr. Hazen's biography. }\end{array}$ & $\begin{array}{l}\text { Salt Palace - } \\
\text { Room 251D }\end{array}$ \\
\hline 11:05 - 11:40 am & $\begin{array}{l}\text { Plenary Address - Dr. Rosemary Knight, Stanford University, } \\
\text { "Geophysical Images of the Near-Surface: What are we really seeing?" } \\
\text { Click here for Dr. Knight's biography. }\end{array}$ & $\begin{array}{l}\text { Salt Palace - } \\
\text { Room 251D }\end{array}$ \\
\hline $11: 40 \mathrm{am}-1: 00 \mathrm{pm}$ & Lunch Break & on own \\
\hline
\end{tabular}

\begin{tabular}{|c|c|c|}
\hline 1:00 - 5:00 pm & $\begin{array}{l}\text { TECHNICAL SESSIONS } \\
\text { Environmental Policy and Management } \\
\text { Role of Stakeholders in Determining Environmental Policy } \\
\text { (Chair: Gautam Pillay, INRA) }\end{array}$ & $\begin{array}{l}\text { Salt Palace - } \\
\text { Room 250A }\end{array}$ \\
\hline $\begin{array}{l}\text { LEAD } \\
1: 00-1: 35 \mathrm{pm}\end{array}$ & $\begin{array}{l}\text { Topic/Session: Environmental Policy and Management } \\
\text { Author - J.D. Wulfhorst, Department of Agricultural Economics \& Rural Sociology, } \\
\text { University of Idaho }\end{array}$ & $\begin{array}{l}\text { Salt Palace - } \\
\text { Room 250A }\end{array}$ \\
\hline 1:35 - 2:00 pm & $\begin{array}{l}\text { Probabilistic Risk Assessment and Multi-Criteria Decision Analysis for the } \\
\text { Management of Contaminated Subsurface } \\
\text { Author - Ibrahim M. Khadam, Utah Water Research Laboratory, Utah State } \\
\text { University } \\
\text { Jagath J. Kaluarachchi, Utah Water Research Laboratory, Utah State University }\end{array}$ & $\begin{array}{l}\text { Salt Palace - } \\
\text { Room 250A }\end{array}$ \\
\hline \multirow[t]{2}{*}{ 2:00 - 2:50 pm } & $\begin{array}{l}\text { Panel Discussion of "Role of Stakeholders in Determining Environmental } \\
\text { Policy" - Organized by Gautam Pillay } \\
\text { Presentations by: } \\
\text { - } \quad \text { J.D. Wulfhorst, University of Idaho } \\
\text { - } \quad \text { Fred Wagner, Utah State University } \\
\text { - } \quad \text { Ron Sims, Utah State University (invited) } \\
\text { - } \quad \text { Phil Bandy, Idaho Department of Environmental Quality (invited) } \\
\text { - } \quad \text { Roy Mink, U.S. Department of Energy (invited) } \\
\text { - } \quad \text { Julia Gustafson, Counsel, Rep. Dennis Rehberg (R-MT) (invited) } \\
\text { Ryan Thomas, Staff Member, U.S. Senate Subcommittee on Interior } \\
\text { Appropriations (invited) }\end{array}$ & $\begin{array}{l}\text { Salt Palace - } \\
\text { Room 250A }\end{array}$ \\
\hline & & Salt Palace - \\
\hline
\end{tabular}




\begin{tabular}{|l|l|l|} 
2:50 - 3:20 pm & Break, refreshments provided & Room 251D \\
\hline 3:20 - 5:00 pm & $\begin{array}{l}\text { CONTINUED: Panel Discussion of “Role of Stakeholders in Determining } \\
\text { Environmental Policy" - Organized by Gautam Pillay }\end{array}$ & $\begin{array}{l}\text { Salt Palace - } \\
\text { Room 250A }\end{array}$ \\
\hline 6:00 - 8:00 pm & $\begin{array}{l}\text { Poster Session \& Catered Reception } \\
\text { All technical posters will be on display; student posters will be judged. } \\
\text { Complimentary hors d'oeuvres and cash bar will be provided for all attendees. To } \\
\text { view poster titles and authors, click here. }\end{array}$ & $\begin{array}{l}\text { Salt Palace - } \\
\text { Room 251D }\end{array}$ \\
\hline
\end{tabular}

\begin{tabular}{|c|c|c|}
\hline $1: 00-4: 10$ pm & $\begin{array}{l}\text { TECHNICAL SESSIONS } \\
\text { Geophysics } \\
\text { (Chair: Russ Hertzog, INEEL) }\end{array}$ & $\begin{array}{l}\text { Salt Palace - } \\
\text { Room 250D }\end{array}$ \\
\hline $\begin{array}{l}\text { LEAD } \\
1: 00-1: 35 \mathrm{pm}\end{array}$ & $\begin{array}{l}\text { Spectral Analysis of Visual Images for Characterizing Hydraulic Conductivity } \\
\text { Fields } \\
\text { Author - Greg A. Oldenborger, Boise State University } \\
\text { Robert A. Schincariol and Lalu Mansinha, University of Western Ontario, London, } \\
\text { Ontario, CAN }\end{array}$ & $\begin{array}{l}\text { Salt Palace - } \\
\text { Room 250D }\end{array}$ \\
\hline $1: 35-2: 00 \mathrm{pm}$ & $\begin{array}{l}\text { Nuclear Probes to Determine the Contents of Buried Waste } \\
\text { Author-Ray Keegan, Idaho National Engineering and Environmental Laboratory } \\
\text { Woo Yoon, Russell Hertzog, Chris McGrath, Idaho National Engineering and } \\
\text { Environmental Laboratory, } \\
\text { Jeffrey Schweitzer, University of Connecticut, Storrs, CT } \\
\text { Donald Steinman, Integrated Physics Measurements, Houston, TX } \\
\text { George Schneider, US Department of Energy, Idaho Falls, ID }\end{array}$ & $\begin{array}{l}\text { Salt Palace - } \\
\text { Room 250D }\end{array}$ \\
\hline $2: 00-2: 25 \mathrm{pm}$ & $\begin{array}{l}\text { Fresnel Volume Attenuation Difference Inversion of Borehole Georadar Data } \\
\text { Author - Timothy C. Johnson, Boise State University } \\
\text { Michael D. Knoll and Warren Barrash, Boise State University }\end{array}$ & $\begin{array}{l}\text { Salt Palace - } \\
\text { Room 250D }\end{array}$ \\
\hline $2: 25-2: 50 \mathrm{pm}$ & $\begin{array}{l}\text { Wave Propagation Studies Through Sediments at In Situ Conditions } \\
\text { Author - Manika Prasad, Stanford University, Stanford California } \\
\text { Sandra Vega and Traci Bryar, Stanford University, Stanford California }\end{array}$ & $\begin{array}{l}\text { Salt Palace - } \\
\text { Room 250D }\end{array}$ \\
\hline $2: 50-3: 20 \mathrm{pm}$ & Break, refreshments provided & $\begin{array}{l}\text { Salt Palace - } \\
\text { Room 251D }\end{array}$ \\
\hline $3: 20-3: 45 p m$ & $\begin{array}{l}\text { Appraisal Analysis in Geophysical Inversion: A Practical Tool for Image } \\
\text { Interpretation } \\
\text { Authors - Partha S. Routh and Michael D. Knoll, Dept of Geosciences, Boise State } \\
\text { University }\end{array}$ & $\begin{array}{l}\text { Salt Palace - } \\
\text { Room 250D }\end{array}$ \\
\hline $3: 45-4: 10 \mathrm{pm}$ & $\begin{array}{l}\text { A Novel Optical Method for Measuring Strain in Coal as a Function of Pore } \\
\text { Pressure } \\
\text { Author-Eric P. Robertson, Idaho National Engineering and Environmental } \\
\text { Laboratory and Colorado School of Mines } \\
\text { Richard L. Christiansen, Colorado School of Mines }\end{array}$ & $\begin{array}{l}\text { Salt Palace - } \\
\text { Room 250D }\end{array}$ \\
\hline 6:00 - 8:00 pm & $\begin{array}{l}\text { Poster Session \& Catered Reception } \\
\text { All technical posters will be on display; student posters will be judged. } \\
\text { Complimentary hors d'oeuvres and cash bar will be provided for all attendees. To } \\
\text { view poster titles and authors, click here. }\end{array}$ & $\begin{array}{l}\text { Salt Palace - } \\
\text { Room 251D }\end{array}$ \\
\hline
\end{tabular}

\begin{tabular}{|c|c|c|}
\hline 1:00 - 5:00 pm & $\begin{array}{l}\text { TECHNICAL SESSIONS } \\
\text { Multi-Discipline Panel Discussion } \\
\text { (Chair: Paul Wichlacz, INEEL) }\end{array}$ & $\begin{array}{l}\text { Salt Palace - } \\
\text { Room 251A }\end{array}$ \\
\hline $1: 00-2: 50 \mathrm{pm}$ & $\begin{array}{l}\text { Panel Discussion of "A Conceptual Model of Flow and Contaminant Transport } \\
\text { at the INEEL" - Organized by Paul Wichlacz } \\
\text { Presentations by: } \\
\text { - Michael Wright, Idaho National Engineering and Environmental Laboratory } \\
\text { - Joseph Rousseau, US Geological Survey } \\
\text { - Thomas Wood, Idaho National Engineering and Environmental Laboratory } \\
\text { - Brennon Orr, North Wind, Inc. } \\
\text { - Robert Starr, Idaho National Engineering and Environmental Laboratory }\end{array}$ & $\begin{array}{l}\text { Salt Palace - } \\
\text { Room 251A }\end{array}$ \\
\hline $2: 50-3: 20$ pm & Break, refreshments provided & $\begin{array}{l}\text { Salt Palace - } \\
\text { Room 251D }\end{array}$ \\
\hline $3: 20-5: 00$ pm & $\begin{array}{l}\text { CONTINUED: Panel Discussion of "A Conceptual Model of Flow and } \\
\text { Contaminant Transport at the INEEL" - Organized by Paul Wichlacz }\end{array}$ & $\begin{array}{l}\text { Salt Palace - } \\
\text { Room } 251 \mathrm{~A}\end{array}$ \\
\hline $6: 00-8: 00$ pm & $\begin{array}{l}\text { Poster Session \& Catered Reception } \\
\text { All technical posters will be on display; student posters will be judged. } \\
\text { Complimentary hors d'oeuvres and cash bar will be provided for all attendees. To } \\
\text { view poster titles and authors, click here. }\end{array}$ & $\begin{array}{l}\text { Salt Palace - } \\
\text { Room } 251\end{array}$ \\
\hline
\end{tabular}




\begin{tabular}{|l|l|l|}
\hline \multicolumn{2}{|l|}{ Tuesday, October 7, 2003 } & Salt Palace \\
\hline 7:30 am - 4:30 pm & Registration Desk Open & $\begin{array}{l}\text { Salt Palace - } \\
\text { Room 251D }\end{array}$ \\
\hline 7:30 - 8:00 am & Continental Breakfast & $\begin{array}{l}\text { Salt Palace - } \\
\text { Room 251D }\end{array}$ \\
\hline 9:50 - 10:20 am & Break, refreshments provided & on own \\
\hline 12:00 - 1:30 pm & Lunch Break & $\begin{array}{l}\text { Salt Palace - } \\
\text { Room 251D }\end{array}$ \\
\hline 3:20 - 3:50 pm & Break, refreshments provided & $\begin{array}{l}\text { Salt Palace - } \\
\text { Room 251D }\end{array}$ \\
\hline 6:00 - 8:00 pm & $\begin{array}{l}\text { Poster Session \& Catered Reception } \\
\text { All technical posters will be on display; student posters will be judged. } \\
\text { Complimentary hors d'oeuvres and cash bar will be provided for all } \\
\text { attendees. To view poster titles and authors, click here. }\end{array}$ & \begin{tabular}{l} 
\\
\hline
\end{tabular} \\
\hline
\end{tabular}

\begin{tabular}{|c|c|c|}
\hline $8: 00$ am - 12:00 pm & $\begin{array}{l}\text { TECHNICAL SESSIONS } \\
\text { Bioremediation } \\
\text { Microbial Remediation } \\
\text { (Chair: Rick Colwell, INEEL) }\end{array}$ & $\begin{array}{l}\text { Salt Palace - } \\
\text { Room } 250 \text { A }\end{array}$ \\
\hline $\begin{array}{l}\text { LEAD } \\
8: 00-8: 35 \text { am }\end{array}$ & $\begin{array}{l}\text { Mineral Surface-Associated Microbial Community Structure at a } \\
\text { Subsurface Uranium Contaminated Site } \\
\text { Author - Gill Geesey, Montana State University } \\
\text { Catherine Reardon, Montana State University } \\
\text { David Cummings, Idaho National Engineering and Environmental } \\
\text { Laboratory } \\
\text { Brent Peyton, Washington State University } \\
\text { David Watson and Barry Kinsall, Oak Ridge National Laboratory }\end{array}$ & $\begin{array}{l}\text { Salt Palace - } \\
\text { Room 250A }\end{array}$ \\
\hline 8:35 - 9:00 am & $\begin{array}{l}\text { Iron (III) Minerals Can Impact the Microbial Reduction of 2,4,6- } \\
\text { Trinitrotoluene } \\
\text { Author - Thomas Borch, Montana State University } \\
\text { Alfred B. Cunningham and Robin Gerlach, Montana State University }\end{array}$ & $\begin{array}{l}\text { Salt Palace - } \\
\text { Room 250A }\end{array}$ \\
\hline 9:00 - 9:25 am & $\begin{array}{l}\text { Influence of Adsorbates on Microbial Interaction with Mineral } \\
\text { Surfaces } \\
\text { Author Allison E. Ray, Idaho State University } \\
\text { Timothy S. Magnuson, Idaho State University } \\
\text { David E. Cummings, Idaho National Engineering and Environmental } \\
\text { Laboratory }\end{array}$ & $\begin{array}{l}\text { Salt Palace - } \\
\text { Room 250A }\end{array}$ \\
\hline $9: 25$ - 9:50 am & $\begin{array}{l}\text { Cr (VI) Reduction by Cellulomonas: Multi-Scale Flow-Cell } \\
\text { Experiments } \\
\text { Author - Brent M. Peyton, Washington State University } \\
\text { Sridhar Viamajala and Vaidee Sivaswamy, Washington State University } \\
\text { William A. Apel, Idaho National Engineering and Environmental Laboratory } \\
\text { Robin Gerlach and Alfred B. Cunningham, Montana State University }\end{array}$ & $\begin{array}{l}\text { Salt Palace - } \\
\text { Room 250A }\end{array}$ \\
\hline $9: 50$ - 10:20 am & Break, refreshments provided & $\begin{array}{l}\text { Salt Palace - } \\
\text { Room 251D }\end{array}$ \\
\hline $10: 20$ - 10:45 am & $\begin{array}{l}\text { Genomic Analysis of a Microbial Community by Microarray } \\
\text { Comparative Genomic Hybridization } \\
\text { Author - Ronald L. Crawford, University of Idaho } \\
\text { Jonathan L. Sebat, Cold Spring Harbor Laboratory, Cold Spring Harbor, NY } \\
\text { Frederick S. Colwell, Idaho National Engineering \& Environmental } \\
\text { Laboratory }\end{array}$ & $\begin{array}{l}\text { Salt Palace - } \\
\text { Room 250A }\end{array}$ \\
\hline $10: 45-11: 10 a m$ & $\begin{array}{l}\text { Influence of Electron Shuttling Compounds on the Reduction of } \\
\text { Metals and Organics } \\
\text { Author - Robin Gerlach, Montana State University } \\
\text { Thomas Borch, Al B. Cunningham, Montana State University } \\
\text { Sridhar Viamajala, Brent M. Peyton, Washington State University } \\
\text { William A. Apel, Idaho National Engineering and Environmental Laboratory }\end{array}$ & $\begin{array}{l}\text { Salt Palace - } \\
\text { Room 250A }\end{array}$ \\
\hline $11: 10$ - 11:35 am & $\begin{array}{l}\text { Microbial Diversity of Mineral-Associated Biofilms Collected from a } \\
\text { Uranium-Contaminated Aquifer } \\
\text { Author- Catherine Reardon, Montana State University } \\
\text { Gill Geesey, Montana State University } \\
\text { David Cummings, Lynn Petzke, Idaho National Engineering and } \\
\text { Environmental Laboratory } \\
\text { David Watson, Barry Kinsall, Oak Ridge National Laboratory }\end{array}$ & $\begin{array}{l}\text { Salt Palace - } \\
\text { Room 250A }\end{array}$ \\
\hline
\end{tabular}




\begin{tabular}{|c|c|c|}
\hline 11:35am - 12:00pm & $\begin{array}{l}\text { Bioremediation of Cr(VI) Contaminated Soil and Groundwater: } \\
\text { Column Experiments } \\
\text { Author - Mahbub Alam, Washington State University } \\
\text { David Yonge, Brent Peyton, and James Petersen, Washington State } \\
\text { University } \\
\text { Akram Hossain, Washington State University, Tri-Cities campus, Richland, } \\
\text { WA }\end{array}$ & $\begin{array}{l}\text { Salt Palace - } \\
\text { Room 250A }\end{array}$ \\
\hline $12: 00-1: 30 \mathrm{pm}$ & Lunch Break & on own \\
\hline
\end{tabular}

\begin{tabular}{|c|c|c|}
\hline 8:00am - 12:00pm & $\begin{array}{l}\text { TECHNICAL SESSIONS } \\
\text { Geochemistry } \\
\text { Geochemistry Tools and Aqueous-Phase Studies } \\
\text { (Chair: George Redden, INEEL) }\end{array}$ & $\begin{array}{l}\text { Salt Palace - } \\
\text { Room 250D }\end{array}$ \\
\hline $\begin{array}{l}\text { LEAD } \\
\text { 8:00 - 8:35 am }\end{array}$ & $\begin{array}{l}\text { Field Portable Electrochemical Sensors for Heavy Metals } \\
\text { Author- J.M. Scaggs, Boise State University } \\
\text { D.D. Russell, W.B. Knowlton, L.R. Warner, R.L. Meyer, and D. Kiri, Boise } \\
\text { State University } \\
\text { W. Bauer, Idaho National Engineering and Environmental Laboratory }\end{array}$ & $\begin{array}{l}\text { Salt Palace - } \\
\text { Room 250D }\end{array}$ \\
\hline 8:35 - 9:00 am & $\begin{array}{l}\text { Effects of Wetting and Drying Cycles on Metal Mobility } \\
\text { Author - Karen E. Wright, Idaho National Engineering and Environmental } \\
\text { Laboratory } \\
\text { D. Craig Cooper, William F. Bauer, and George D. Redden, Idaho National } \\
\text { Engineering and Environmental Laboratory }\end{array}$ & $\begin{array}{l}\text { Salt Palace - } \\
\text { Room 250D }\end{array}$ \\
\hline 9:00 - 9:25 am & $\begin{array}{l}\text { A Benzene Selective Electrode } \\
\text { Author - L. R. Warner, Boise State University } \\
\text { D. D. Russell, Boise State University }\end{array}$ & $\begin{array}{l}\text { Salt Palace - } \\
\text { Room 250D }\end{array}$ \\
\hline $9: 25$ - 9:50 am & $\begin{array}{l}\text { Mineral Surface Reactivity Using Isotopic Oxygen Exchange with } \\
\text { Secondary Ion Mass Spectrometry } \\
\text { Author - Recep Avci, Montana State University } \\
\text { Cem Karahan and Jan Sunner, Montana State University } \\
\text { Anita Gianotto, and Gary Groenewold, Idaho National Engineering and } \\
\text { Environmental Laboratory } \\
\text { Senay Yalcin, Bahcesehir University, Istanbul, Turkey }\end{array}$ & $\begin{array}{l}\text { Salt Palace - } \\
\text { Room 250D }\end{array}$ \\
\hline $9: 50$ - 10:20 am & Break, refreshments provided & $\begin{array}{l}\text { Salt Palace - } \\
\text { Room 251D }\end{array}$ \\
\hline $10: 20-10: 45$ am & $\begin{array}{l}\text { Study of Mesoporous Sorption Phenomena Using a SiO } \\
\text { Author - Soil Sima Washington, Washington State University } \\
\text { David Yonge, Brent Peyton, and Reid Miller, Washington State University } \\
\text { Gary Groenewold, Idaho National Engineering and Environmental } \\
\text { Laboratory }\end{array}$ & $\begin{array}{l}\text { Salt Palace - } \\
\text { Room 250D }\end{array}$ \\
\hline $10: 45-11: 10$ am & $\begin{array}{l}\text { Applications and Technological Spin-offs of Electron LINACS to Sub- } \\
\text { Surface and other Environmental Sciences } \\
\text { Author-Doug Wells, Idaho State University } \\
\text { F. A. Selim, J. Kwofie, F. J. Harmon, Idaho State University } \\
\text { G. Erickson, Boise State University } \\
\text { J.L. Jones, T. White, T. Roney, Idaho National Engineering and } \\
\text { Environmental Laboratory }\end{array}$ & $\begin{array}{l}\text { Salt Palace - } \\
\text { Room 250D }\end{array}$ \\
\hline $11: 10-11: 35$ am & $\begin{array}{l}\text { Fabrication of ChemFETS for Uranium Detection in Geological } \\
\text { Subsurface Groundwater } \\
\text { Author - William Knowlton, Boise State University } \\
\text { Dale Russell, Dorian Kiri, Jonathan Scaggs, Lisa Warner, and Ryan Meyer, } \\
\text { Boise State University }\end{array}$ & $\begin{array}{l}\text { Salt Palace - } \\
\text { Room 250D }\end{array}$ \\
\hline 11:35am - 12:00pm & $\begin{array}{l}\text { The Effect of Co-Solvents in Modified Fenton's Reagent } \\
\text { Author - Brant A. Smith, Washington State University } \\
\text { Richard J. Watts, Washington State University } \\
\text { David A. Atkinson, Idaho National Engineering and Environmental } \\
\text { Laboratory }\end{array}$ & $\begin{array}{l}\text { Salt Palace - } \\
\text { Room 250D }\end{array}$ \\
\hline $12: 00-1: 30 p m$ & Lunch Break & on own \\
\hline
\end{tabular}

\begin{tabular}{|l|l|l|}
\hline 8:00am - 12:00pm & $\begin{array}{l}\text { TECHNICAL SESSIONS } \\
\text { Modeling } \\
\text { Modeling Methods } \\
\text { (Chair: Akram Alshawabkeh, Northeastern University) }\end{array}$ & $\begin{array}{l}\text { Salt Palace = } \\
\text { Room 251A }\end{array}$ \\
\hline $\begin{array}{l}\text { LEAD } \\
\text { 8:00 - 8:35 am }\end{array}$ & $\begin{array}{l}\text { Time Domain Forward Computational Modeling of Complex Dispersive } \\
\text { Media for Underground Sensing Applications }\end{array}$ & $\begin{array}{l}\text { Salt Palace - } \\
\text { Room 251A }\end{array}$ \\
& $\begin{array}{l}\text { Author - Carey Rappaport, Northeastern University, Boston, MA } \\
\end{array}$
\end{tabular}




\begin{tabular}{|c|c|c|}
\hline & Akram Alshawabkeh, Northeastern University, Boston, MA & \\
\hline $8: 35-9: 00 \mathrm{am}$ & $\begin{array}{l}\text { Optimal Collocation Solution of Steady-State Convection-Diffusion } \\
\text { Equations } \\
\text { Author - Stephen H. Brill, Boise State University }\end{array}$ & $\begin{array}{l}\text { Salt Palace - } \\
\text { Room 251A }\end{array}$ \\
\hline 9:00 - 9:25 am & $\begin{array}{l}\text { The Use of a Physical Test Cell to Evaluate Assumptions Made in Fate } \\
\text { and Transport Modeling } \\
\text { Author-Daniel B. Shrum, Envirocare of Utah, Inc. } \\
\text { Timothy L. Orton, Envirocare of Utah, Inc. }\end{array}$ & $\begin{array}{l}\text { Salt Palace - } \\
\text { Room 251A }\end{array}$ \\
\hline 9:25 - 9:50 am & $\begin{array}{l}\text { Simulation of Colloidal Transport via the Lattice Boltzmann Method } \\
\text { Authors - Hakan Basagaoglu and Paul Meakin, Idaho National Engineering } \\
\text { and Environmental Laboratory }\end{array}$ & $\begin{array}{l}\text { Salt Palace - } \\
\text { Room } 251 \mathrm{~A}\end{array}$ \\
\hline $9: 50-10: 20 \mathrm{am}$ & Break, refreshments provided & $\begin{array}{l}\text { Salt Palace - } \\
\text { Room 251D }\end{array}$ \\
\hline $10: 20-10: 45$ am & $\begin{array}{l}\text { A Mixing-Cell Model for Assessment of Water Flow and Solute } \\
\text { Transport in the Unsaturated Zone } \\
\text { Author-Arthur S. Rood, Idaho National Engineering and Environmental } \\
\text { Laboratory }\end{array}$ & $\begin{array}{l}\text { Salt Palace - } \\
\text { Room } 251 \mathrm{~A}\end{array}$ \\
\hline $10: 45-11: 10 \mathrm{am}$ & $\begin{array}{l}\text { Modeling 2D Water Flow in Heterogeneous Unsaturated Media at } \\
\text { INTEC: Uncertainty Analysis } \\
\text { Author - Joan Q. Wu, Washington State University } \\
\text { Richard Rossi and Limin Yang, Washington State University } \\
\text { Annette L. Schafer and Larry C. Hull, Idaho National Engineering and } \\
\text { Environmental }\end{array}$ & $\begin{array}{l}\text { Salt Palace - } \\
\text { Room } 251 \mathrm{~A}\end{array}$ \\
\hline $11: 10-11: 35$ am & $\begin{array}{l}\text { Electrical and Petrophysical Parameter Modeling and Inversion of } \\
\text { Ferron Sandstone Data } \\
\text { Author - Robert B. Szerbiak, Boise State University } \\
\text { George A. McMechan, The University of Texas, Dallas, TX } \\
\text { Craig B. Forster and Stephen H. Snelgrove, University of Utah }\end{array}$ & $\begin{array}{l}\text { Salt Palace - } \\
\text { Room 251A }\end{array}$ \\
\hline 11:35am - 12:00pm & $\begin{array}{l}\text { Geoenvironmental Research at the INEEL Geocentrifuge Laboratory } \\
\text { Author - Alan T. Stadler, Director, INEEL Geocentrifuge Research } \\
\text { Laboratory }\end{array}$ & $\begin{array}{l}\text { Salt Palace - } \\
\text { Room 251A }\end{array}$ \\
\hline $12: 00-1: 30 \mathrm{pm}$ & Lunch Break & on own \\
\hline
\end{tabular}

\begin{tabular}{|c|c|c|}
\hline 1:30 - 5:05 pm & $\begin{array}{l}\text { TECHNICAL SESSIONS } \\
\text { Bioremediation } \\
\text { Remediation Techniques } \\
\text { (Chair: Al Cunningham, Montana State University) }\end{array}$ & $\begin{array}{l}\text { Salt Palace - } \\
\text { Room 250A }\end{array}$ \\
\hline $\begin{array}{l}\text { LEAD } \\
1: 30-2: 05 \mathrm{pm}\end{array}$ & $\begin{array}{l}\text { Controlled Cultivation: Strategies for Improving our Understanding of } \\
\text { the Biology behind Bioremediation } \\
\text { Author - Yuri Gorby, Pacific Northwest National Laboratory }\end{array}$ & $\begin{array}{l}\text { Salt Palace - } \\
\text { Room 250A }\end{array}$ \\
\hline $2: 05-2: 30 \mathrm{pm}$ & $\begin{array}{l}\text { Applying Enzyme Activity Probes to Evaluate a TCE Contaminated } \\
\text { Aquifer } \\
\text { Author - Scott R. Clingenpeel, Idaho State University } \\
\text { Michelle H. Howard-Jones, and Mary E. Watwood, Idaho State University } \\
\text { William K. Keener, Idaho National Engineering and Environmental } \\
\text { Laboratory }\end{array}$ & $\begin{array}{l}\text { Salt Palace - } \\
\text { Room 250A }\end{array}$ \\
\hline $2: 30-2: 55 \mathrm{pm}$ & $\begin{array}{l}\text { Remediation of Metal Contaminants by Microbially Mediated Calcite } \\
\text { Precipitation } \\
\text { Author-Robert W. Smith, D.M. Cosgrove, J.L. Taylor, University of Idaho } \\
\text { Y. Fujita, F.S. Colwell, T.L. McLing, Idaho National Engineering and } \\
\text { Environmental Laboratory }\end{array}$ & $\begin{array}{l}\text { Salt Palace - } \\
\text { Room 250A }\end{array}$ \\
\hline $2: 55-3: 20 \mathrm{pm}$ & $\begin{array}{l}\text { Potential for Enhancement of In Situ Bioremediation by } \\
\text { Electrochemical Methods } \\
\text { Author-Akram N. Alshawabkeh, Dept of Civil and Environmental } \\
\text { Engineering, NE University, Boston, MA } \\
\text { Xingzhi Wu and James Wang, Dept of Civil and Environmental Engineering, } \\
\text { NE University, Boston, MA } \\
\text { David B. Gent, Environmental Lab, US Army Engineering Research \& } \\
\text { Development Center, Vicksburg, MS }\end{array}$ & $\begin{array}{l}\text { Salt Palace - } \\
\text { Room 250A }\end{array}$ \\
\hline $3: 20$ - 3:50 pm & Break, refreshments provided & $\begin{array}{l}\text { Salt Palace - } \\
\text { Room 251D }\end{array}$ \\
\hline $3: 50-4: 15 p m$ & $\begin{array}{l}\text { Subsurface Biofilm Barriers for Containment and Remediation of } \\
\text { Contaminated Groundwater } \\
\text { Author - Alfred B. Cunningham, Montana State University } \\
\text { Robert R. Sharp and Margo Adgie, Manhattan College, Riverdale NY } \\
\text { Randy Hiebert and Garth James, MSE Technology Applications, Butte MT }\end{array}$ & $\begin{array}{l}\text { Salt Palace - } \\
\text { Room 250A }\end{array}$ \\
\hline
\end{tabular}




\begin{tabular}{|l|l|l|} 
4:15 - 4:40 pm & $\begin{array}{l}\text { Vadose Zone Bioremediation: Gene Probes, Intermediates, and Binding } \\
\text { for PAHs }\end{array}$ & $\begin{array}{l}\text { Salt Palace - } \\
\text { Room 250A }\end{array}$ \\
\hline $\begin{array}{l}\text { Author - Ronald C. Sims, Utah State University } \\
\text { Kevin A. Hall, Yanna Liang, Karl Nieman, and Charles Miller, Utah State } \\
\text { University }\end{array}$ & $\begin{array}{l}\text { Environmental Factors Affecting Natural Attenuation/Bioremediation of } \\
\text { MTBE at a Full-Scale Site }\end{array}$ \\
\hline $\begin{array}{l}\text { Author - Aaron E. Swank, Utah State University, Utah Water Research } \\
\text { Laboratory } \\
\text { Mark H. Greenwood and Ronald C. Sims, Utah State University, Utah Water } \\
\text { Research Laboratory }\end{array}$ & $\begin{array}{l}\text { Room 250A } \\
\text { 6oster Session \& Catered Reception } \\
\text { All technical posters will be on display; student posters will be judged. } \\
\text { Complimentary hors d'oeuvres and cash bar will be provided for all } \\
\text { attendees. To view poster titles and authors, click here. }\end{array}$ \\
\hline
\end{tabular}

\begin{tabular}{|c|c|c|}
\hline $1: 30-5: 30 \mathrm{pm}$ & $\begin{array}{l}\text { TECHNICAL SESSIONS } \\
\text { Technology Transfer } \\
\text { The University-Industry Relationship } \\
\text { (Chair: Steven Billingsley, INRA) }\end{array}$ & $\begin{array}{l}\text { Salt Palace - } \\
\text { Room 250D }\end{array}$ \\
\hline $1: 30-3: 20$ pm & \begin{tabular}{|l} 
Panel Discussion of the University-Industry Relationship - Organized by \\
Steven Billingsley \\
Presentations by: \\
- $\quad$ Bradley B. Bertoch, President, Wayne Brown Institute (invited) \\
- $\quad$ Richard Clayton, President, T2M (Technology to Market) \\
- $\quad$ Norris F. Krueger, Faculty of Entrepreneurship, Idaho Small \\
Business Development Center, Boise State University \\
- Dale S. Richards, Wayne Brown Institute (invited) \\
William Ruud, Professor, Department of Management, Boise State \\
- University \\
Mel Ustad, Associate Dean of Research, University of South \\
Dakota
\end{tabular} & $\begin{array}{l}\text { Salt Palace - } \\
\text { Room 250D }\end{array}$ \\
\hline $3: 20-3: 50 \mathrm{pm}$ & Break, refreshments provided & $\begin{array}{l}\text { Salt Palace - } \\
\text { Room 251D }\end{array}$ \\
\hline $3: 50-5: 30$ & $\begin{array}{l}\text { CONTINUED: Panel Discussion of the University-Industry Relationship } \\
\text { - Organized by Steven Billingsley }\end{array}$ & $\begin{array}{l}\text { Salt Palace - } \\
\text { Room 250D }\end{array}$ \\
\hline 6:00 - 8:00 pm & $\begin{array}{l}\text { Poster Session \& Catered Reception } \\
\text { All technical posters will be on display; student posters will be judged. } \\
\text { Complimentary hors d'oeuvres and cash bar will be provided for all } \\
\text { attendees. To view poster titles and authors, click here. }\end{array}$ & $\begin{array}{l}\text { Salt Palace - } \\
\text { Room 251D }\end{array}$ \\
\hline
\end{tabular}

\begin{tabular}{|c|c|c|}
\hline 1:30 - 5:30 pm & $\begin{array}{l}\text { TECHNICAL SESSIONS } \\
\text { Hydrology } \\
\text { (Chair: Ingrid Padilla, University of Puerto Rico) }\end{array}$ & $\begin{array}{l}\text { Salt Palace - } \\
\text { Room 251A }\end{array}$ \\
\hline $\begin{array}{l}\text { LEAD } \\
1: 30-2: 05 \mathrm{pm}\end{array}$ & $\begin{array}{l}\text { Emission from DNAPL Source Zones with Complex Entrapment } \\
\text { Architecture } \\
\text { Author-Tissa H. Illangasekare, Colorado School of Mines } \\
\text { Satawat Saenton, Elena Moreno-Barbero, Colorado School of Mines }\end{array}$ & $\begin{array}{l}\text { Salt Palace - } \\
\text { Room } 251 \mathrm{~A}\end{array}$ \\
\hline $2: 05-2: 30 \mathrm{pm}$ & $\begin{array}{l}\text { Simulation of Episodic Flood Events at the Idaho National Engineering } \\
\text { and Environmental Laboratory (INEEL) Vadose Zone Research Park } \\
\text { Author - Kristine Baker, Idaho National Engineering and Environmental } \\
\text { Laboratory } \\
\text { Larry Hull, Idaho National Engineering and Environmental Laboratory }\end{array}$ & $\begin{array}{l}\text { Salt Palace - } \\
\text { Room 251A }\end{array}$ \\
\hline $2: 30-2: 55 \mathrm{pm}$ & $\begin{array}{l}\text { Integrated Bayesian Network for Watershed Information Management } \\
\text { Author - Ahmed Said, Civil and Environmental Department, Utah State } \\
\text { University } \\
\text { David K. Stevens, Civil and Environmental Department, Utah State University } \\
\text { Gerald Sehlke, Idaho National Engineering and Environmental Laboratory }\end{array}$ & $\begin{array}{l}\text { Salt Palace - } \\
\text { Room 251A }\end{array}$ \\
\hline $2: 55-3: 20 \mathrm{pm}$ & $\begin{array}{l}\text { Estimating Transmissivity from Pumping Data using the Sensitivity } \\
\text { Matrix Eigenvectors } \\
\text { Author-Tom Clemo, Boise State University } \\
\text { Paul Michaels, Boise State University } \\
\text { R. Michael Lehman, Idaho National Engineering and Environmental } \\
\text { Laboratory }\end{array}$ & $\begin{array}{l}\text { Salt Palace - } \\
\text { Room 251A }\end{array}$ \\
\hline $3: 20-3: 50$ pm & Break, refreshments provided & $\begin{array}{l}\text { Salt Palace - } \\
\text { Room 251D }\end{array}$ \\
\hline
\end{tabular}




\begin{tabular}{|l|l|l|} 
3:50 - 4:15 pm & $\begin{array}{l}\text { Rate-Limited Mass Transfer of Volatile Organic Compounds in } \\
\text { Unsaturated Porous Media } \\
\text { Autor - Ingrid Y. Padilla, Ph.D., Dept of Civil Engineering and Surveying, } \\
\text { University of Puerto Rico, Mayagüez }\end{array}$ & $\begin{array}{l}\text { Salt Palace - } \\
\text { Room 251A }\end{array}$ \\
\hline 4:15 - 4:40 pm & $\begin{array}{l}\text { NMR Imaging of Microbial Transport in Porous Media } \\
\text { Author - Justin P. Gage, Montana State University, Bozeman } \\
\text { Joseph D. Seymour, Sarah L. Codd, Robin Gerlach, and Alfred B. } \\
\text { Cunningham, Montana State University }\end{array}$ & $\begin{array}{l}\text { Salt Palace - } \\
\text { Room 251A }\end{array}$ \\
\hline 4:40 - 5:05 pm & $\begin{array}{l}\text { Use of Support Vector Machines in Groundwater Monitoring Network } \\
\text { Design } \\
\text { Authors - Tirusew Asefa and Mariush Kemblowski, Utah State University }\end{array}$ & $\begin{array}{l}\text { Salt Palace - } \\
\text { Room 251A }\end{array}$ \\
\hline 5:05 - 5:30 pm & $\begin{array}{l}\text { Comparisons Between the Water Quality Index and the Biotic Indicators } \\
\text { Author - Ahmed Said, Civil and Environmental Department, Utah State } \\
\text { University } \\
\text { David K. Stevens, Civil and Environmental Department, Utah State University } \\
\text { Wayne G. Minshall, Stream Ecology Center - Department of Biological } \\
\text { Sciences, Idaho State University } \\
\text { Ron Rope, Idaho National Engineering and Environmental Laboratory }\end{array}$ & $\begin{array}{l}\text { Salt Palace - } \\
\text { Room 251A }\end{array}$ \\
\hline 6:00 - 8:00 pm & $\begin{array}{l}\text { Poster Session \& Catered Reception } \\
\text { All technical posters will be on display; student posters will be judged. } \\
\text { Complimentary hors d'oeuvres and cash bar will be provided for all } \\
\text { attendees. To view poster titles and authors, click here. }\end{array}$ \\
\hline
\end{tabular}

\begin{tabular}{|l|l|l|}
\hline Wednesday, October 8, 2003 & Salt Palace \\
\hline 7:30 am - 1:00 pm & Registration Desk Open & $\begin{array}{l}\text { Salt Palace - } \\
\text { Room 251D }\end{array}$ \\
\hline 7:30 - 8:30 am & Continental Breakfast & $\begin{array}{l}\text { Salt Palace - } \\
\text { Room 251D }\end{array}$ \\
\hline 8:00 - 8:30 am & $\begin{array}{l}\text { Student Poster Awards Presentation } \\
\text { To view poster titles and authors, click here. }\end{array}$ & $\begin{array}{l}\text { Salt Palace - } \\
\text { Room 251D }\end{array}$ \\
\hline $10: 20-10: 50 \mathrm{am}$ & Break and Poster Clean Up, refreshments provided & on own \\
\hline 12:30 pm & Lunch Break / End of Conference & \\
\hline
\end{tabular}

\begin{tabular}{|c|c|c|}
\hline 8:30am - 12:05pm & $\begin{array}{l}\text { TECHNICAL SESSIONS } \\
\text { Geochemistry } \\
\text { Geochemistry Applied to Nuclear Waste Treatment } \\
\text { (Chair: Bob Smith, UI) }\end{array}$ & $\begin{array}{l}\text { Salt Palace - } \\
\text { Room 250A }\end{array}$ \\
\hline $\begin{array}{l}\text { LEAD } \\
8: 30 \text { - 9:05 am }\end{array}$ & $\begin{array}{l}\text { SIMS Characterization of Soils Leached Using Sequential Aqueous } \\
\text { Extractions } \\
\text { Co-Author-Gary Groenewold, Idaho National Engineering and } \\
\text { Environmental Laboratory } \\
\text { Co-Author - Recep Avci, Montana State University } \\
\text { Marnie Cortez and Anita Gianotto, Idaho National Engineering and } \\
\text { Environmental Laboratory } \\
\text { Cem Karahan, Montana State University }\end{array}$ & $\begin{array}{l}\text { Salt Palace - } \\
\text { Room 250A }\end{array}$ \\
\hline 9:05 - 9:30 am & $\begin{array}{l}\text { Sorption of Gadolinium onto Nontronite and Goethite as a Function of } \\
\text { pH and lonic Strength } \\
\text { Authors - Scott A. Wood and Alexander F. Redkin, University of Idaho } \\
\text { George Redden and Larry C. Hull, Idaho National Engineering and } \\
\text { Environmental Laboratory }\end{array}$ & $\begin{array}{l}\text { Salt Palace - } \\
\text { Room 250A }\end{array}$ \\
\hline 9:30 - 9:55 am & $\begin{array}{l}\text { Evidence for the Occurrence of Microbial Iron Reduction in Bulk } \\
\text { Aerobic Unsaturated Sediments } \\
\text { Author-D. Craig Cooper, Idaho National Engineering and Environmental } \\
\text { Laboratory } \\
\text { William A. Smith, Don T. Fox, Mitchell A. Plummer, and Larry C. Hull, Idaho } \\
\text { National Engineering and Environmental Laboratory } \\
\text { Ravi K. Kukkadapu, Pacific Northwest National Laboratory }\end{array}$ & $\begin{array}{l}\text { Salt Palace - } \\
\text { Room 250A }\end{array}$ \\
\hline 9:55 - 10:20 am & $\begin{array}{l}\text { Stability of Colloidal Material from the Hanford Sediments } \\
\text { Author-S. Czigány, } \\
\text { Markus Flury, Jeffrey Boyle, and James B. Harsh, Washington State } \\
\text { University }\end{array}$ & $\begin{array}{l}\text { Salt Palace - } \\
\text { Room 250A }\end{array}$ \\
\hline $10: 20-10: 50 \mathrm{am}$ & Break and Poster Clean Up, refreshments provided & $\begin{array}{l}\text { Salt Palace - } \\
\text { Room 251D }\end{array}$ \\
\hline
\end{tabular}




\begin{tabular}{|l|l|l|} 
10:50 - 11:15 am & $\begin{array}{l}\text { Degradation of Chlorinated Solvents in the Vadose Zone at a } \\
\text { Radioactive Waste Subsurface Disposal Area }\end{array}$ & $\begin{array}{l}\text { Salt Palace - } \\
\text { Room 250A }\end{array}$ \\
\hline $\begin{array}{l}\text { Author - Larry C. Hull, Idaho National Engineering and Environmental } \\
\text { Laboratory }\end{array}$ & $\begin{array}{l}\text { Salt Palace - } \\
\text { Room 250A }\end{array}$ \\
\hline $\begin{array}{l}\text { Incorporation and Adsorption of Cesium in Zeolitic Minerals } \\
\text { Author - James B. Harsh, Washington State University } \\
\text { Youjun Deng, Markus Flury, and Jeffrey Boyle, Washington State } \\
\text { University } \\
\text { James Young and Joseph Ford, Pacific Northwest National Laboratory, } \\
\text { Richland, WA }\end{array}$ & $\begin{array}{l}\text { Salt Palace - } \\
\text { Room 250A }\end{array}$ \\
\hline $\begin{array}{l}\text { 11:40am - 12:05pm am } \\
\text { The Partitioning of Plutonium to INEEL Soils and Sediments }\end{array}$ & $\begin{array}{l}\text { Author - Rosara Payne, Washington State University } \\
\text { Meang Ho Lee, Sue Clark, Washington State University }\end{array}$ \\
\hline
\end{tabular}

\begin{tabular}{|c|c|c|}
\hline 8:30am - 12:30pm & $\begin{array}{l}\text { TECHNICAL SESSIONS } \\
\text { Modeling } \\
\text { Modeling Environments } \\
\text { (Chair: Jeff Sondrup, INEEL) }\end{array}$ & $\begin{array}{l}\text { Salt Palace - } \\
\text { Room 250D }\end{array}$ \\
\hline $\begin{array}{l}\text { LEAD } \\
8: 30 \text { - 9:05 am }\end{array}$ & $\begin{array}{l}\text { Particle-Based Modeling of Multiphase Flow } \\
\text { Author - Paul Meakin, Idaho National Engineering and Environmental } \\
\text { Laboratory } \\
\text { Alexandre Tartakovsky, Hakan Basagoaglu and Hai Huang, Idaho National } \\
\text { Engineering and Environmental Laboratory }\end{array}$ & $\begin{array}{l}\text { Salt Palace - } \\
\text { Room 250D }\end{array}$ \\
\hline 9:05 - 9:30 am & $\begin{array}{l}\text { Determination of Soil Hydraulic Properties using a Geocentrifuge } \\
\text { Author-H. Nakajima, Idaho National Engineering and Environmental } \\
\text { Laboratory } \\
\text { J.R. Lord, M.G. Gifford, E.D. Mattson, A.T. Stadler, Idaho National } \\
\text { Engineering and Environmental Laboratory }\end{array}$ & $\begin{array}{l}\text { Salt Palace - } \\
\text { Room 250D }\end{array}$ \\
\hline 9:30 - 9:55 am & $\begin{array}{l}\text { Nonlinear Advective Contaminant Transport in Clay Under } \\
\text { Consolidation } \\
\text { Author - Akram. N. Alshawabkeh, Dept of Civil \& Environmental } \\
\text { Engineering, NE University, Boston, MA } \\
\text { Nima Rahbar, Dept of Civil \& Environmental Engineering, NE University, } \\
\text { Boston, MA }\end{array}$ & $\begin{array}{l}\text { Salt Palace - } \\
\text { Room 250D }\end{array}$ \\
\hline $9: 55-10: 20$ am & $\begin{array}{l}\text { Methanogen Biomass in Hydrate-Bearing Sediments } \\
\text { Author-S. Boyd, Idaho National Engineering and Environmental } \\
\text { Laboratory } \\
\text { F.S. Colwell, D. Reed, and M.E. Delwiche, Idaho National Engineering and } \\
\text { Environmental Laboratory }\end{array}$ & $\begin{array}{l}\text { Salt Palace - } \\
\text { Room 250D }\end{array}$ \\
\hline $10: 20-10: 50$ am & Break and Poster Clean Up, refreshments provided & $\begin{array}{l}\text { Salt Palace - } \\
\text { Room 251D }\end{array}$ \\
\hline $10: 50-11: 15$ am & $\begin{array}{l}\text { Application of Ensemble Kalman Filter to Unsaturated - Saturated } \\
\text { Groundwater Model } \\
\text { Qiang Shu and Mariush Kemblowski, Utah State University }\end{array}$ & $\begin{array}{l}\text { Salt Palace - } \\
\text { Room 250D }\end{array}$ \\
\hline $11: 15-11: 40$ am & $\begin{array}{l}\text { Modeling Non-Drainable (Residual) NAPL in the Vadose Zone } \\
\text { Author - RJ Lenhard, Idaho National Engineering and Environmental } \\
\text { Laboratory } \\
\text { M Oostrom and MD White, PNNL, Richland, WA } \\
\text { JH Dane, Auburn University }\end{array}$ & $\begin{array}{l}\text { Salt Palace - } \\
\text { Room 250D }\end{array}$ \\
\hline 11:40am - 12:05pm & $\begin{array}{l}\text { Amplitude and Frequency Experimental Field Measurements of a } \\
\text { Rotating-Imbalance Seismic Source Associated with Changes in } \\
\text { Lithology Surrounding a Borehole } \\
\text { Author - Stephen R. Novascone, Idaho National Engineering and } \\
\text { Environmental Laboratory } \\
\text { Michael J. Anderson, University of Idaho } \\
\text { David M. Weinberg, Idaho National Engineering and Environmental } \\
\text { Laboratory } \\
\text { Jack H. Cole, University of Arkansas, Fayetteville, AR, USA } \\
\end{array}$ & $\begin{array}{l}\text { Salt Palace - } \\
\text { Room 250D }\end{array}$ \\
\hline $12: 05-12: 30 \mathrm{pm}$ & $\begin{array}{l}\text { Prediction of Immiscible Displacement on Different Scales } \\
\text { Author - Alexandre Tartakovsky, Idaho National Engineering and } \\
\text { Environmental Laboratory } \\
\text { Hai Huang, Idaho National Engineering and Environmental Laboratory }\end{array}$ & $\begin{array}{l}\text { Salt Palace - } \\
\text { Room 250D }\end{array}$ \\
\hline $12: 30 \mathrm{pm}$ & Lunch Break / End of Conference & on own \\
\hline
\end{tabular}


Copyright () 2003. Inland Northwest Research Alliance (INRA) Inc. 151 North Ridge Avenue, Suite 140. Idaho Falls, ID 83402. Tel: (208) 524-4800. Fa; This site best viewed in Internet Explorer 6.0 or Netscape Navigator 7.0 at a resolution of $1024 X 768$ This site was last updated: 08/02/2004

http://www.inra.org/new\%20inra\%20web/INRA\%20NEWS,\%20EVENTS\%20PAGES/SSS\%2003/... $11 / 5 / 2004$ 


\title{
CARBON SEQUESTRATION POTENTIAL OF BASINS OF SOUTHERN IDAHO: BIG SKY CARBON SEQUESTRATION PARTNERSHIP
}

\author{
Robert W. Smith, Nathan P. Ericson, University of Idaho, Idaho Falls, ID 83402 \\ Travis L. McLing, Idaho National Engineering and Environmental Laboratory, Idaho \\ Falls, ID 83415 \\ Warren Barrash, William P. Clement, Boise State University, Boise, ID 83725 \\ John P. Kaszuba, Los Alamos National Laboratory, Los Alamos, NM 87545
}

Carbon sequestration is one approach to stabilize or reduce the levels of potentially climate-changing greenhouse gasses in the earth atmosphere. Geologic sequestration is the storage or entombment of carbon dioxide in naturally occurring subsurface geologic formations. Because approximately one third of the carbon dioxide emitted annually in the United States is from point sources, source capture coupled with geologic entombment has high potential to limit emissions. Geologic sequestration of $\mathrm{CO}_{2}$ occurs via three interrelated processes. Hydrodynamic trapping dominates in short time frames where a distinct supercritical $\mathrm{CO}_{2}$ rich fluid fills pore space within subsurface media. In the medium-term, solubility trapping becomes important in which the supercritical $\mathrm{CO}_{2}$ dissolves into subsurface fluids (e.g., formation waters). Mineral trapping can become the dominate sequestration process at longer time-scales where $\mathrm{CO}_{2}$ reacts with subsurface media to form solid-phase carbonates. The permanence of sequestration by the three trapping processes is the inverse of their trapping time scale. Mineralization trapping offers the most permanent sequestration, hydrodynamic trapping the least. In an ideal sequestration site $\mathrm{CO}_{2}$ would be permanently stored utilizing multiple trapping mechanisms.

As part of the U.S. Department of Energy funded Big Sky Carbon Sequestration Partnership, we are assessing the potential of northern Rocky Mountain and Great Plain geologic formations for long-term carbon sequestration. Of particular interest are the mafic volcanic rock and volcanic bounded basins of southern Idaho because they serve as an example of the inherent potential for permanent mineral trapping of large amounts of $\mathrm{CO}_{2}$ in the abundant basalts of the northwestern U.S. Carbon dioxide injected into the subsurface dissolves in pore-water to form carbonic acid that is neutralized by the weathering of host-rock minerals to produce carbonate and bicarbonate ions (alkalinity) and/or mineral carbonates. For example, the weathering of the calcic component of plagioclase feldspar (a common basalt mineral phase) to calcite and a clay mineral can be written as

$\mathrm{CaAl}_{2} \mathrm{Si}_{2} \mathrm{O}_{8}+2 \mathrm{H}_{2} \mathrm{O}+\mathrm{CO}_{2} \rightarrow \mathrm{CaCO}_{3}+\mathrm{Al}_{2} \mathrm{Si}_{2} \mathrm{O}_{5}(\mathrm{OH})_{4}$

The thermodynamics for this reaction indicate that for any $\mathrm{CO}_{2}$ pressure important for sequestration, the reaction will proceed as written, entombing the introduced $\mathrm{CO}_{2}$ as solid calcium carbonate. Mineralization potential will be highest in rocks with abundant Ca-, $\mathrm{Mg}$-, and Fe-silicates such as basalt and lowest in rocks poor in these phases (e.g., sandstone). The time frame and extent of mineralization for a given subsurface environment (and hence its mineralization potential) are functions of the weathering rates 
and the abundance of silicate phases. We are conducting a preliminary assessment of the $\mathrm{CO}_{2}$ sequestration potential of volcanic rocks and volcanic hosted basins in southern Idaho using The Geochemist's Workbench computer code and a generalized mineral dissolution rate law that we have developed. Simulation results suggest that more that 20 $\mathrm{kg}$ carbon $\mathrm{m}^{-3}$ of rock can be sequestered in typical basalt. Furthermore, mineral trapping becomes the dominant form of sequestration after approximately 300 years. In addition to considering direct trapping in basalts, we are also considering the potential of basalt as an impermeable cap rock. The simulations indicate that mineralization processes can result in a significant decrease in porosity (and by inference permeability), suggesting that the cap rock seal may become more robust with time in some subsurface environments. Overall, our preliminary assessments based on mineral reactivity indicate that mafic volcanic rocks and volcanic bounded sedimentary basins of southern Idaho have significant potential for the permanent sequestration of $\mathrm{CO}_{2}$. 
Presentation Type Requested: ORAL

\section{Topical Area: Energy Production, Carbon Sequestration}

\section{Author Information:}

Robert W. Smith

Department of Biological and

Agricultural Engineering

University of Idaho at Idaho Falls

1776 Science Center Drive

Idaho Falls, ID 83402

Phone: (208) 282-7954

FAX: (208) 282-7950

e-mail: smithbob@uidaho.edu

Warren Barrash

Center for Geophysical

Investigation of the Shallow

Subsurface

Department of Geosciences

Boise State University

Boise, ID 83725

Tel: (208) 426-1229

FAX: (208) 426-3888

e-mail:wbarrash@boisestate.edu

\author{
Nathan P. Ericson \\ Department of Geological \\ Sciences \\ University of Idaho at Idaho Falls \\ 1776 Science Center Drive \\ Idaho Falls, ID 83402 \\ Phone: (208) 282-7936 \\ FAX: (208) 282-7950 \\ e-mail: ericnath@if.uidaho.edu \\ William P. Clement \\ Center for Geophysical \\ Investigation of the Shallow \\ Subsurface \\ Boise State University \\ Boise, ID 83725 \\ Tel: (208) 426-4307 \\ FAX: (208) 426-3888 \\ e-mail: billc@cgiss.boisestate.edu
}

Travis L. McLing

Geosciences Research

Idaho National Engineering and

Environmental Laboratory

PO Box 1625 MS 2107

Idaho Falls, ID 83415

Phone: (208) 526-7269

FAX: (208) 526-0875

e-mail: tm1@inel.gov

John P. Kaszuba

Isotope and Nuclear Chemistry

Los Alamos National Laboratory

P.O. Box 1663 MS J514

Los Alamos, NM 87545

Tel: (505) 6657832

FAX: (505) 6654955

e-mail: jkaszuba@lanl.gov 


\title{
SENSITIVITY OF CARBON SEQUESTRATION COSTS TO ECONOMIC AND BIOLOGICAL UNCERTAINTIES
}

\author{
Susan M. Capalbo and John M. Antle \\ Montana State University \\ Bozeman, Montana, USA \\ Siân Mooney \\ University of Wyoming \\ Laramie, Wyoming, USA \\ Keith Paustian \\ Colorado State University \\ Fort Collins, Colorado, USA
}

INRA Presentation Abstract Topical Area: (carbon sequestration session) monitoring, risk assessment, and policy; social science and environmental policy issues; critical parameters for predictive monitoring

Modifying current agricultural management practices as a means of sequestering carbon has been shown to be a relatively low cost way to offset greenhouse gas emissions. In this presentation, we examine the sensitivity of the estimates of the amount of soil carbon sequestered and the costs of sequestering carbon to uncertainties in the underlying economic and biological parameters of the modeling framework and to scale of analysis. We present a brief overview of the economic versus technical potential for terrestrial sequestration in the northern Rockies, and a description of the economic-biophysical simulation model. An application is made to the dryland grain production systems of the U.S. Northern Plains under a per-hectare carbon payment policy. We show that the resulting changes in the marginal costs and corresponding quantities of soil carbon sequestered are a nonlinear function of the changes in the soil carbon rates, yields, or economic parameters, and depend upon the spatial heterogeneity of the area. The analysis of changes in yields supports the argument that sequestering soil $\mathrm{C}$ could be a long-term win-win situation for producers and society. In the short run, providing incentives to producers to switch production practices in order to sequester soil $\mathrm{C}$ could lead to higher productivity in the long run that would induce farmers to maintain these practices without further incentives. 


\title{
SOIL ORGANIC CARBON SEQUESTRATION POTENTIAL IN NORTH CENTRAL MONTANA
}

\author{
Ross S. Bricklemyer and Perry R. Miller \\ Montana State University \\ Bozeman, Montana, USA
}

INRA Presentation Abstract Topical Area: carbon sequestration (special session); monitoring, risk assessment, and policy; sensors/monitoring; subsurface experiments and research

Continuing interest in terrestrial carbon sequestration in agricultural soils as a greenhouse gas mitigation strategy has led to the desire to estimate mitigation potential of various management practices across the United States. North central Montana is primarily dryland small grain production with a long history of tillage based management. In an across-the-fence comparison of no-till $(6+y r s)$ versus conventional tillage $(30+y r s)$ management, no-till had significantly higher SOC content at 5 of 6 sites in north central Montana. Annual SOC gains due to no-till ranged from 0.13 to $0.4 \mathrm{t} \mathrm{ha}^{-1}$, with an average of $0.28 \mathrm{t}$ ha-1. Increasing $\mathrm{C}$ inputs to the soil and reducing oxidation of soil organic carbon (SOC) are keys to sequestering $\mathrm{C}$ in soil. Many factors influence soil carbon dynamics including soil disturbance, soil texture, cropping intensity and diversity, and soil inputs such as nitrogen fertilizer. 


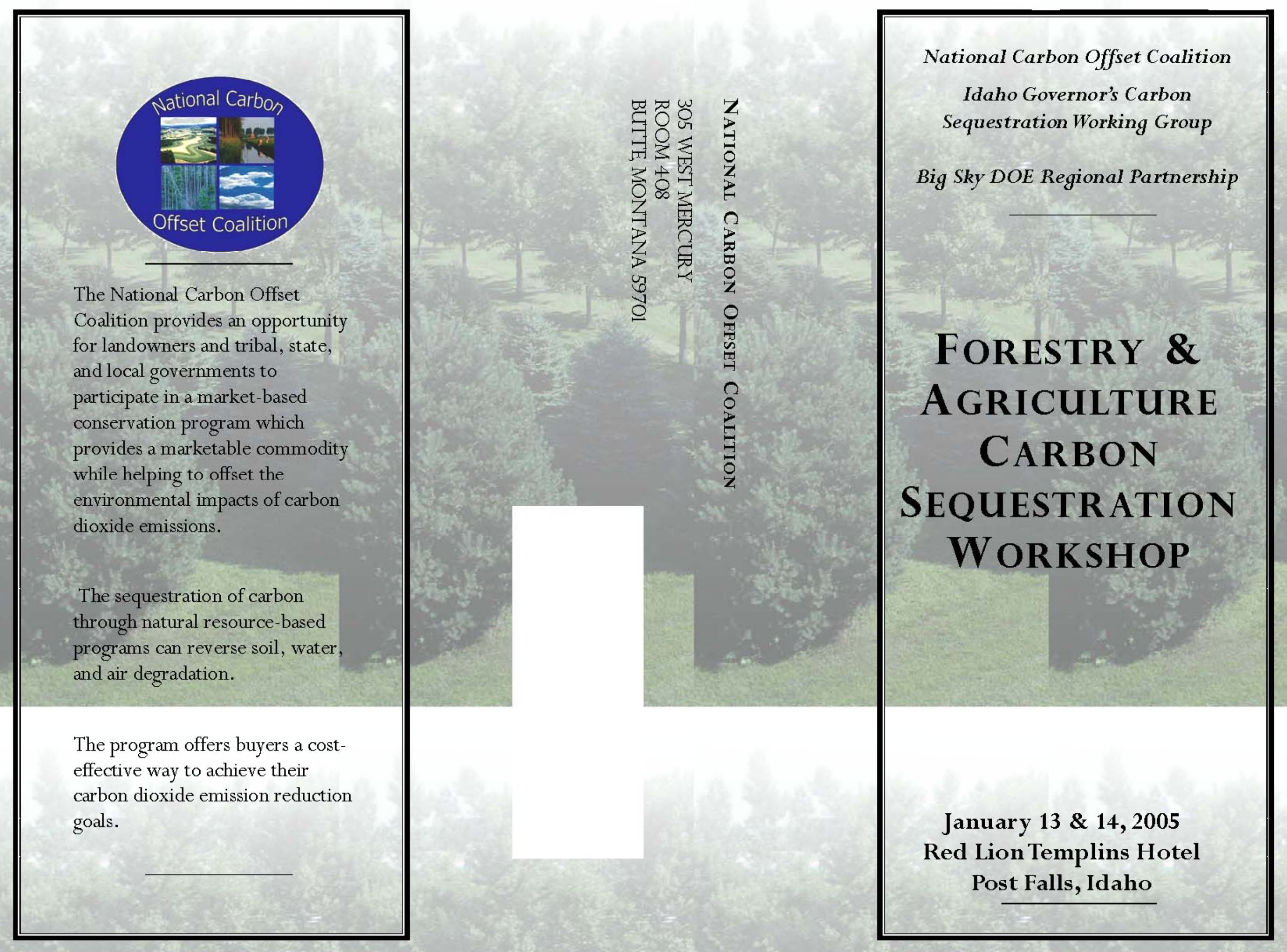




\section{FORESTRY \& \\ Agriculture CARBON \\ SEQUESTRATION \\ WORKSHOP}

The National

Carbon Offset

Coalition

working in

partnership

with the Idaho

Governor's

Carbon

Sequestration Working Group and the Big Sky DOE Regional Partnership is offering a workshop specifically designed to instruct attendees about the carbon sequestration trading opportunities available on private, state, and tribal lands. The goal of this workshop is to create a national portfolio capable of meeting the trading requirements of the emerging markets as part of a DOE grant.

\section{AGENDA}

REGISTRATION

Thursday, January 13, 2005

\begin{tabular}{|c|c|}
\hline $7: 30 \mathrm{am}$ & Registration \\
\hline $8: 30 \mathrm{am}$ & Introductions \\
\hline $8: 45 \mathrm{am}$ & Overview-Workshop \\
\hline $9: 00 \mathrm{am}$ & Carbon Sequestration Science \\
\hline 10:00 am & Break \\
\hline 10:15 am & $\begin{array}{l}\text { Carbon Sequestration Policy \& Ancillary } \\
\text { Benefits }\end{array}$ \\
\hline $11: 15 \mathrm{am}$ & $\begin{array}{l}\text { NCOC Organization -- Operating Policies, } \\
\text { Rel ationship Between the Landowner, } \\
\text { Aggregator, Broker, \& Buyers }\end{array}$ \\
\hline 12:00 & Lunch — Big Sky Regional Partnership \\
\hline $1: 00 \mathrm{pm}$ & The Market \\
\hline $2: 15 \mathrm{pm}$ & Initial Proposal (Planning the Proposal) \\
\hline $3: 00 \mathrm{pm}$ & Break \\
\hline $3: 15 \mathrm{pm}$ & $\begin{array}{l}\text { contimaation of Initial Proposal (Planning the } \\
\text { Proposal) }\end{array}$ \\
\hline \multirow[t]{2}{*}{$5: 00 \mathrm{pm}$} & Adjourn for the day \\
\hline & Friday, January 14, 2005 \\
\hline $8: 00 \mathrm{am}$ & $\begin{array}{l}\text { Questions \& Review of Previous Day } \\
\text { Discussions }\end{array}$ \\
\hline $9: 00 \mathrm{am}$ & $\begin{array}{l}\text { Submission of Initial Proposal, Contracts, } \\
\text { Marketing \& Fund Disbursement }\end{array}$ \\
\hline 10:00 am & Break \\
\hline $10: 15 \mathrm{am}$ & Monitoring \& Ver ification During Contract \\
\hline $11: 30 \mathrm{am}$ & Work on Individual Projects \\
\hline 12:00 & Lunch \\
\hline $1: 00 \mathrm{pm}$ & contimaation of Work on Individual Projects \\
\hline $2: 30$ to $3: 00 \mathrm{pm}$ & Follow-up Questions \& Adjourn \\
\hline
\end{tabular}

Name

Address

City, State

Phone

Email

A block of rooms have been set aside under the name of $\mathrm{NCOC}$.

Hotel Rates: $\$ 64.00 / \mathrm{sgl}$ *plus sales tax $8.5 \%$

Red Lion Templins Hotel (800) 733-5466

\section{Dead line to receive this} rate is Decem ber 13, 2004

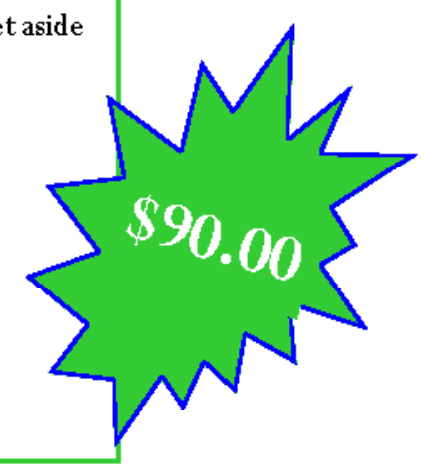

Method of Payment

$\square$ Check payable to: NCOC

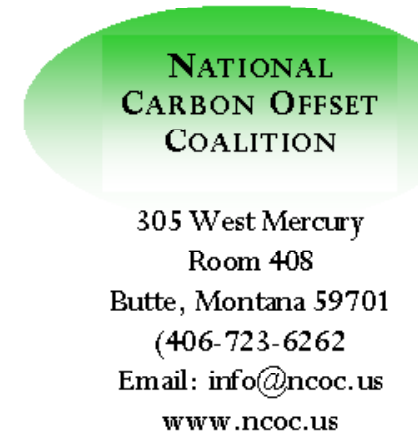


The National Carbon Offset Coasition provides an opportunity for landowners and tribat, state, and locat governments to participate in a market. based conservation program that provides a marketable commodity while helping to offset the errvironmental impacts of carbon dioxide emissions.

The sequestration of carbon through natural resource-based programs can reverse soll, water, and air degradation.

The program offers buyers a cost-effective way to achieve their carbon dioxide emission reduction goals.
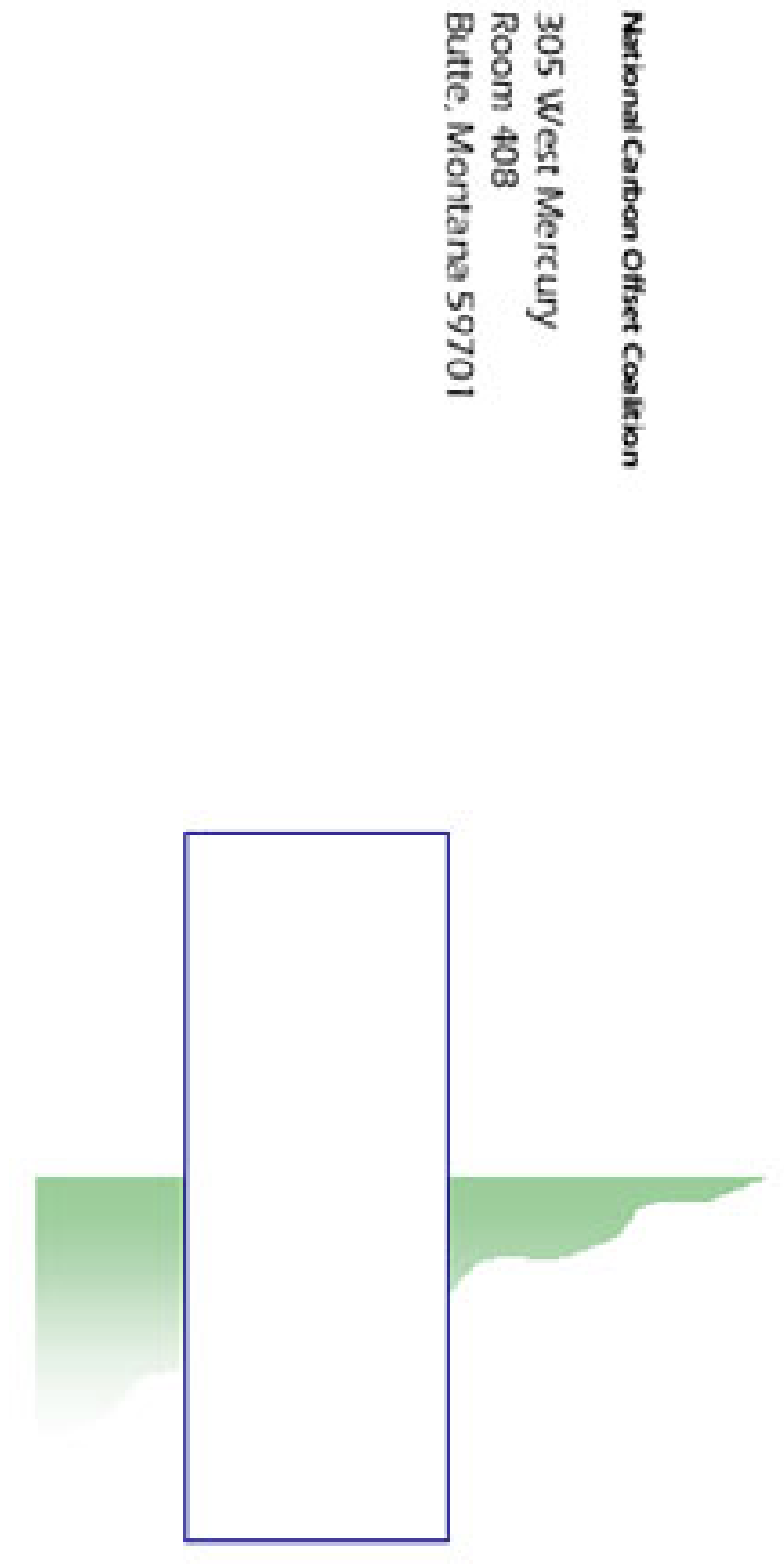

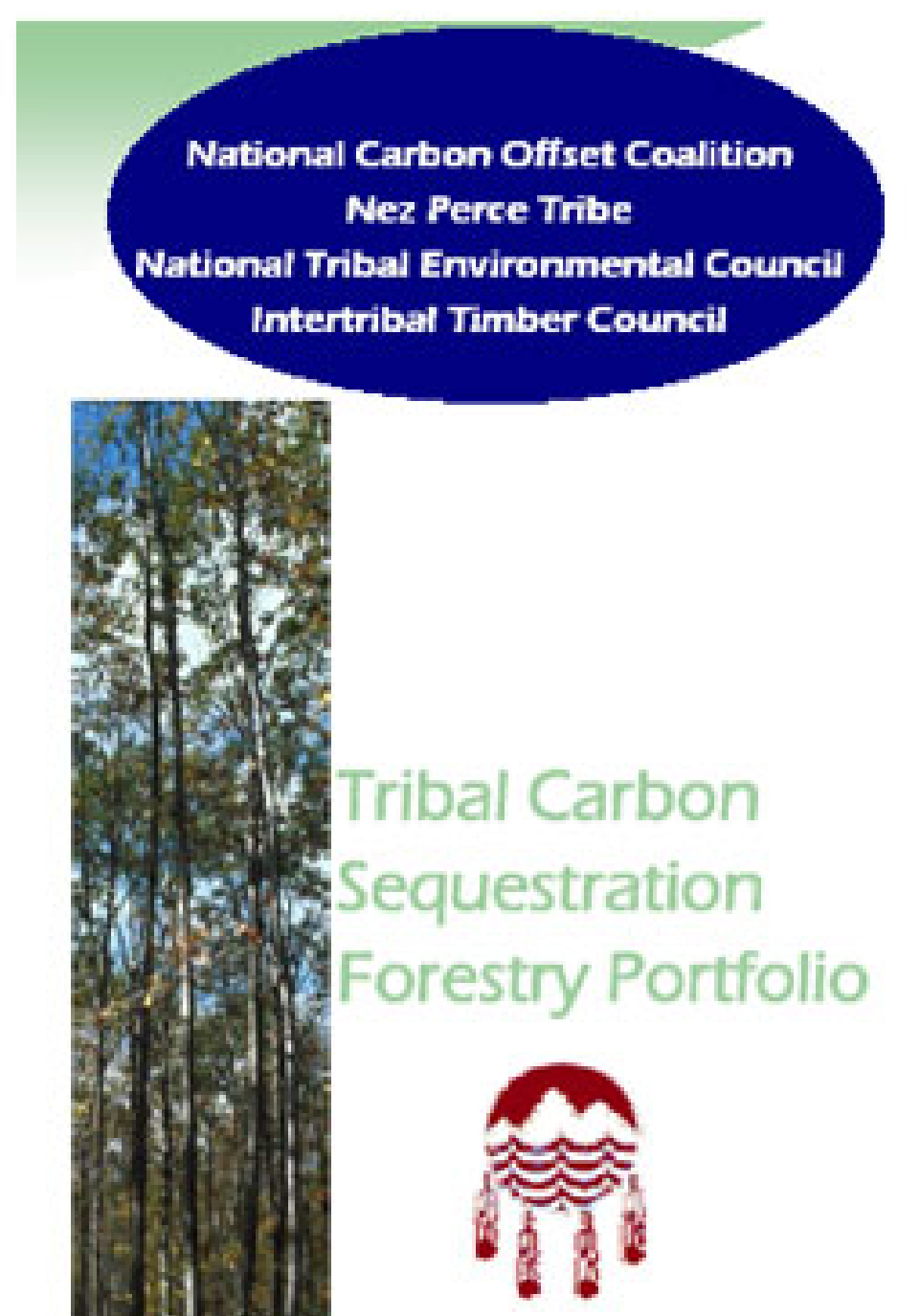

January 11 thru 12, 2005

Red Lion Inn-Spokane, Washington 


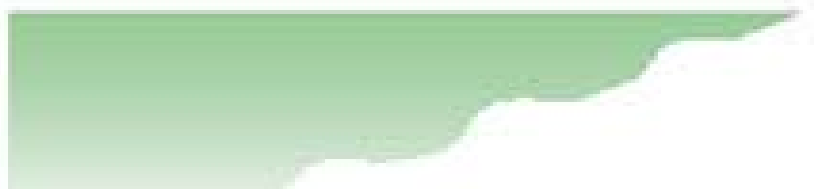

\section{Agenda}

\section{Tuesdry, January 11.2005}

7:30 $\mathrm{mm} \quad$ Registration

\section{Tribal Carbon}

a: $30 \mathrm{~mm}$

introductions

$8.45 \mathrm{~mm}$

Overview-Workshop, Past Tribal Efforts, Progect Types \& Tribal Forestry Portfobo

\section{Forestry Portfolio}

\section{Workshop}

The National

\section{Carbon Offset}

Coalition working

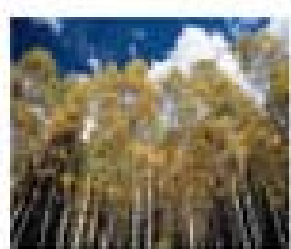

in partnership with the Nez Perce

Tribe and the National Tribas

Environmental Council is offering a

workshop specifically designed to

instruct attendees about the carbon

sequestration trading opportunities

avaliable on tribal tands. The goal of

this workshop is to create a national

tribal forestry portfolio capable of

meeting the trading requirements

of the emerging markets.
9.15 am

Carbon Sequestration science, Policy. Market, $\delta$ Anciliary Benefits

10:15 am Break

10-30 am NCOC Organtzation - Operating Policies, Reitionship Between the Landowner, Aggregator, Broker, \&. Bupers

11:15 am Big Sky Partnership Outiool

$1200 \quad$ Lunch (hosted)

$200 \mathrm{pm} \quad$ Break

2.15 to $5.00 \mathrm{pm}$ intiat Proposal (Planning the Propotati

Wednesdiry, January 12,2005

800 am Ouestions \& Revew of Previous Day Discussiom

9,00 am

Suburission of inviai Proposal Contracts, Marketing \& Fund Disbursemens

$10.00 \mathrm{am}$

Break

10:15am

BuA Policies

$10.45 \mathrm{am}$

Monitoring \& Verdication During Contract

1200 Lunch (hosted)

1:00 pm Work on individual Projects

230 to $3: 30 \mathrm{pm}$ Follow up Ouestions \&. Acjocrn
$100 \mathrm{pm} \quad$ The Market
Name

Address:

City, State

Prone

Email

A block of rooms thrs been set aside under the nume of NCOC.

Hiceet Itates $56300 / 4 \mathrm{gg}$ $\$ 73,00 /$ dto

pers a sovestar to tw

Cat fied Lion inn for tevervation (Boo, 733.546

Deactine to secure these rees in December 11.2000

Method of Payment

Check payable to: NCOC

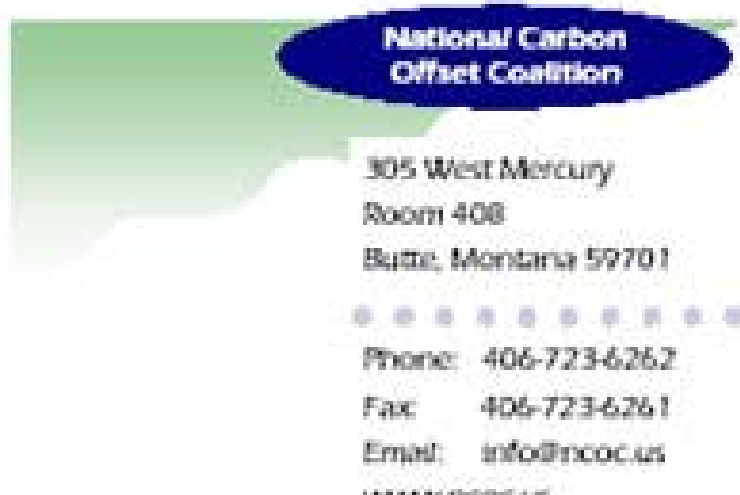

